VILNIAUS GEDIMINO TECHNIKOS UNIVERSITETAS

Algimantas MAČIULIS

\title{
ŠIUOLAIKINĖS LIETUVOS
}

ARCHITEKTÜROS MENINĖS RAIŠKOS TENDENCIJOS

DAKTARO DISERTACIJA

HUMANITARINIAI MOKSLAI, MENOTYRA (03H),

SKULPTŪRA IR ARCHITEKTŪRA (H312)

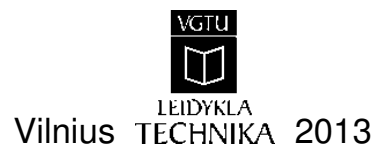


Disertacija rengta 2009-2013 metais Vilniaus Gedimino technikos universitete.

\section{Mokslinis vadovas}

doc. dr. Kęstutis LUPEIKIS (Vilniaus Gedimino technikos universitetas, humanitariniai mokslai, menotyra $-03 \mathrm{H})$.

VGTU leidyklos TECHNIKA 2181-M mokslo literatūros knyga http://leidykla.vgtu.lt

ISBN 978-609-457-579-2

(C) VGTU leidykla TECHNIKA, 2013

(C) Algimantas Mačiulis, 2013

maciulis.algimantas@gmail.com 
VILNIUS GEDIMINAS TECHNICAL UNIVERSITY

Algimantas MAČIULIS

\section{TRENDS OF ARTISTIC EXPRESSION IN CONTEMPORARY LITHUANIAN ARCITECTURE}

DOCTORAL DISSERTATION

HUMANITIES,

HISTORY AND THEORY OF ARTS $(03 \mathrm{H})$,

SCULPTURE AND ARCHITECTURE (H312)

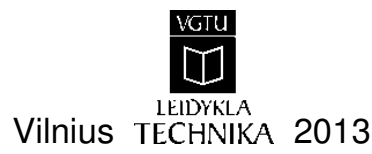


Doctoral dissertation was prepared at Vilnius Gediminas Technical University in 2009-2013.

\section{Scientific Supervisor}

Assoc Prof Dr Kęstutis LUPEIKIS (Vilnius Gediminas Technical University, Humanities, History and Theory of Arts $-03 \mathrm{H})$. 


\section{Reziumè}

Tyrimo objektas yra pasaulinès architektūros stilių meninė raiška Lietuvos architektūroje. Remiantis panašaus pobūdžio užsienio tyrinètojų darbais, nustatomi atskiri pasaulinès architektūros stilių ir krypčių meninès raiškos bruožai Lietuvos architektūroje. Tyrimo pabaigoje, remiantis išnagrinèta medžiaga ir objektais, sukuriamas meninès raiškos bruožais paremtas, stilių ir krypčių skirstymo modelis, ivertinantis skirtingos meninès raiškos objektu paplitimą šiuolaikineje Lietuvos architektūroje. Siekiant tyrimo tikslo keliami tokie uždaviniai:

1. Aptikti ir identifikuoti užsienio architektūros kryptis įtakojusias Lietuvos moderniają architektūrą iki 1990-ųų:

- nustatyti jų raiškos bruožus, savitumus, paplitimą;

- $\quad$ susieti jas su šiuolaikine architektūra.

2. Apžvelgti skirtingų architektūros krypčių meninès raiškos įvairovę 19902013 m.:

- nustatyti jų raiškos bruožus, savitumus, paplitimą;

- nurodyti tendencijas.

3. Sukurti normatyvinị stilių ir krypčių skirstymo modelį, kuriame atsispindètu išnagrinèti objektai, padèsiantị ịvertinti šiuolaikinès Lietuvos architektūros stilių ir krypčių meninès raiškos kontekstą.

Disertaciją sudaro ịvadas, trys skyriai, rezultatų apibendrinimas, naudotos literatūros ir autoriaus publikacijų disertacijos tema sąrašai. İvadiniame skyriuje aptariama tiriamoji problema, darbo aktualumas, aprašomas tyrimu objektas, formuluojamas darbo tikslas bei uždaviniai, aprašoma tyrimų metodika, darbo mokslinis naujumas, darbo rezultatu praktinè reikšmè, ginamieji teiginiai. Ivado pabaigoje pristatomos autoriaus paskelbtos publikacijos disertacijos tema ir disertacijos struktūra.

Pirmasis disertacijos skyrius skirtas Lietuvos moderniosios architektūros raidos analizei iki 1990-ųjų, užsienio architektūros stilių ir krypčių Lietuvos architektūroje apžvalgai. Antrajame disertacijos skyriuje nustatomi užsienio architektūros stiliai ir kryptys Lietuvos architektūroje nuo 1990-ujų, taip pat jų galima ịtaka architektūros tendencijoms. Trečiasis tyrimo skyrius skirtas norminio raiškos modelio teoriniam pagrindimui, grafiniam jo išpildymui bei gautiems rezultatams aprašyti, taip pat palyginimui su panašaus pobūdžio tyrimais.

Disertacijos tema yra išspausdinti 3 moksliniai straipsniai recenzuojamuose mokslo leidiniuose, disertacijos rengimo metu skaityti 2 pranešimai mokslinèse konferencijose ir 2 pranešimai seminaruose 


\section{Abstract}

The subject of this research focuses on the artistic expression of global architectural styles in contemporary Lithuanian architecture. Based on the similar works of foreign scholars, separate global architectural styles and trends in Lithuanian architecture are defined. In the end of the study, based on the evidence explored and objects reviewed, normative model of artistic expression is created. Graphic evaluation of styles and trends helps to identify the patterns of expression, overall principles of creative interfaces, their overlapping, development over time, while allowing to monitor the stylistic context. In order to achieve the goal, following tasks have been set:

1. Detection and identification of foreign architectural styles and trends in modern architecture of Lithuania, until 1990's:

- identify features of their expression, specificity, prevalence;

- assign them to contemporary Lithuanian architecture.

2. Overview the diversity of the different architectural trends in 1990-2013.

- identify features of their expression, specificity, prevalence;

- specify the tendencies.

3. Create a normative model of styles and trends, which reflects the objects examined, and helps to assess the context of artistic expression in contemporary Lithuanian architecture.

Dissertation consists of an introduction, three chapters, conclusions, bibliography and the list of authors' publications related to the research topic. Introductory chapter discusses the research problem, its relevance, describes the object of research, formulates aims and objectives, describes the research methodology, scientific novelty, practical significance of the results, and the defence statements.

First chapter of the dissertation contains definition of the evolution of Modern architecture in Lithuania until 1990's. The second chapter establishes global architectural styles and trends in Lithuanian architecture after 1990' and their possible contribution to the future design tendencies. The third chapter is devoted to the study of normative model of artistic expression, theoretical justification of its graphic fulfillment and description of the results obtained, as well as the comparisons with similar studies.

Three research articles in peer-reviewed journals were published, as well as two reports in scientific conferences and two reports in educational seminars were presented, related to the dissertation topic. 


\section{Santrumpos ir paaiškinimai}

\section{Santrumpos}

$\begin{array}{lll}\text { deš. }- \text { dešimtmetis } & \text { aut. }- \text { autorius } & \text { pr. }- \text { pradžia } \\ \text { a. }- \text { amžius } & \text { kt. }- \text { kiti } & \text { g. }- \text { gatvė } \\ \text { m. }- \text { metai } & \text { vid. }- \text { vidurys } & \text { angl. - angliškai } \\ \text { archit. - architektas } & \text { pab. - pabaiga } & \text { liet. - lietuviškai } \\ \text { proj. - projektuotojas } & & \end{array}$

\section{Sąvokos}

Šiuolaikiné architektūra. Šiame darbe šiuolaikinès architektūros terminas naudojamas apibūdinti architektūros objektus, sukurtus po 1990-ujų metų. Ši riba nustatyta formaliai, ivvertinus socialinius ir politinius pokyčius, vykusius minètu laikotarpiu, o taip pat ir tai, jog architektūra, kaip meno sritis, yra glaudžiai susijusi su šiais pokyčiais.

Architektūros stilius, kryptis. Siekiant susisteminti meninius ir kūrybinius principus, apibūdinti vienos ar kitos menininkų grupès kūrybini braižą, menotyroje susiduriama su terminologijos neapibrèžtumu. Stiliaus, krypties, kartais meninio judèjimo terminai naudojami neapibrežtai, skirtumai tarp šių sąvokų neaiškūs, terminų ribos nèra konkrečios.

Dailès žodyne terminas stilius apibrěžiamas kaip išraiškos vienovè, būdinga meno kūriniui arba kūrinių grupei, dailininko, architekto, tautos, meninio regiono, epochos kūrybai. Teigiama, jog stilius formuojasi veikiamas socialinių, kultūrinių, religinių bei paties meno raidos dèsningumų. Kartu tai ir viena prieštaringiausių, ivvairiais laikotarpiais skirtingai interpretuotų dailètyros ar 
architektūrologijos sąvokų. Dažniausiai jai suteikiama istorinio (arba epochos) stiliaus reikšmè, nurodanti istorijos periodo kūrinių savitumą (gotika, renesansas, barokas ir pan.). Kartais stiliumi ịvardinamas individualus menininko bruožas, autoriaus kūrybos etapas, istorinio stiliaus raidos fazè arba regioninė pakraipa. Neretai terminui suteikiamas platus, neapibrěžtas, metaforiškas turinys. Jis tapatinamas su politinès, socialinès, kultūros istorijos chronologija (viktorijos stilius) arba su bet kuria menine tendencija bei kryptimi (plytų stilius, rūstusis stilius).

Skirtingos meno mokyklos įvairiai aiškina stiliaus prigimtị, struktūrą ir funkcijas. Ikonologijos atstovai pabrèžia simbolinị stiliaus aspektą, sociologai stiliaus ryši su visuomenine aplinka. Labiausiai išpopuliarèjo formaliojo metodo koncepcija, stilių siejantị su formos principų sistema. XX a. 8-ąjame dešimtmetyje postmodernizmo estetika ir nauji istorinių tyrimų duomenys lèmé stiliaus sampratos krizę. Imta kritikuoti abstraktų, apibendrinantị termino pobūdį, ieškoti naujų meno ịvairovès sisteminimo priemonių. Šiuolaikinejje menotyroje stiliaus kategorija dažnai pakeičiama giminingomis sąvokomis - dailès mokykla, kryptimi, judejjimu (Matulevičiūtè 1999). Amy Dempsey enciklopediniame meno vadove „Stiliai, judejjimai ir kryptys“ pripažista šių terminų neapibrež̌tumą, todèl stiliumi vadina tam tikrų judejjimų ir krypčių visumą, pasižyminčią vienu, ar keliais bendrais bruožais (Dempsey 2004).

Architektūrologijoje susiduriama su panašiomis problemomis dèl terminų neapibréžtumo, todèl šiame darbe architektūros stiliais vadinsime tris pagrindinius raidos etapus (laikotarpius) - modernizmą, vèlyvajji modernizmą ir postmodernizmą. Architektūros kryptimi vadinsime minètuose stiliuose pastebimus vienos ar kitos architektu grupès kūrybos principus, turint omenyje, jog stilius vienija kryptis, o kryptyse atsiranda objektai.

Išimtimi laikysime tarptautinio stiliaus ${ }^{l}$ sąvoką. Ši, moderniosios architektūros kryptis užsienio tyrinètojų ịvardinta dar 1932 metais, tarptautinès architektūros parodos Niujorko mieste (JAV) metu (Barr 1932). Šiame tyrime nèra siekiama sukurti naujo šios architektūrinès krypties pavadinimo, todèl nagrinèjant užsienio architektūros tyrinètojų medžiagą, siekiant nenutolti nuo originalių šaltinių, funkcionalioji moderniosios architektūros kryptis, remiantis šaltiniais, bus vadinama tarptautiniu stiliumi.

Užsienio architektūrologijoje ị skirtingas kalbas neverčiamos architektūros kryptys high-tech ir slick-tech šiame darbe bus pateikiamos anglų kalba, kursyvu.

Menine raiška šiame tyrime vadinama meninių priemonių visuma, nurodanti vieno ar kito objekto stilių ar kryptį.

${ }^{1}$ angl. International style 


\section{Turinys}

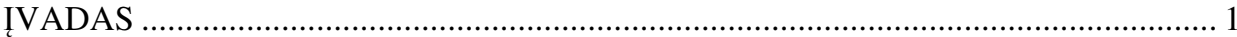

Problemos formulavimas ir darbo aktualumas ........................................................ 1

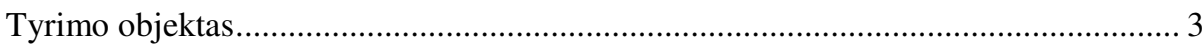

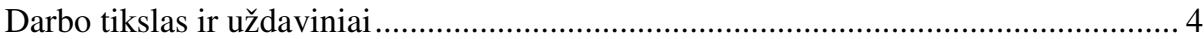

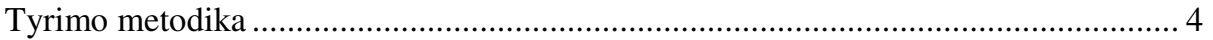

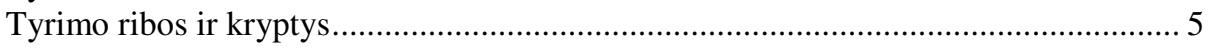

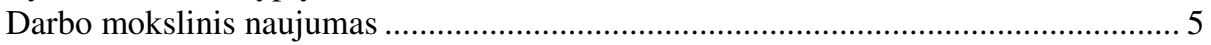

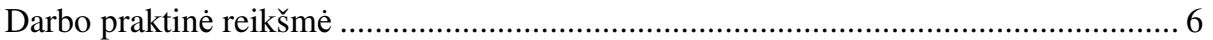

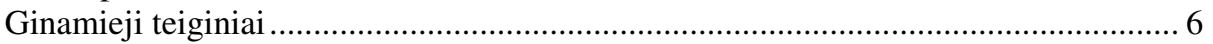

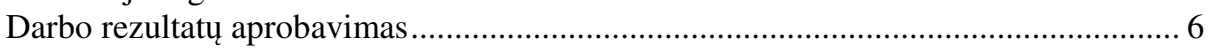

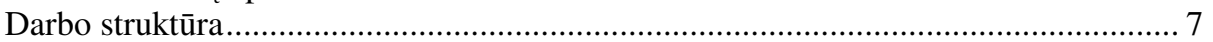

1. MODERNIOSIOS LIETUVOS ARCHITEKTŪROS RAIDA PASAULINIAME

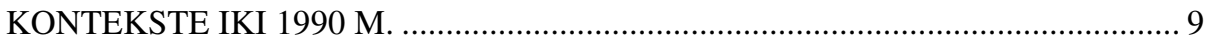

1.1. Vertybiniai - idejjiniai kūrybos panašumai. Funkcinė estetika ............................ 11

1.2. Kritinis regionalizmas ir tautiškumo aspektas moderniojoje Lietuvos

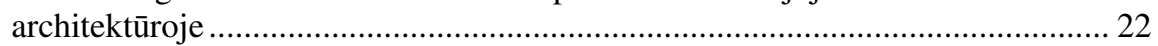

1.3. Meninès raiškos priemonės ekspresyvumo ir plastiškumo paieškose. ………..... 36

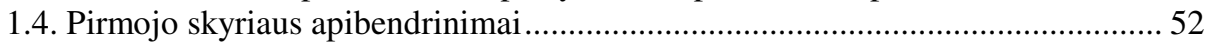

2. PASAULINIŲ STILISTINIŲ TENDENCIJŲ RAIŠKA ŠIUOLAIKINĖJE

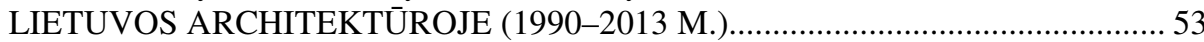

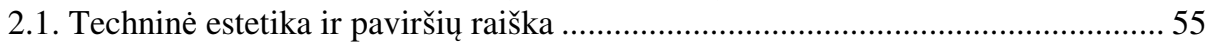

2.2. Kompleksiška postmodernizmo raiška. Istorizmas, stilizacija ir metafora............ 86 
2.3. Dekonstruktyvizmo ir minimalizmo tendencijos šiuolaikinejje Lietuvos architektūroje

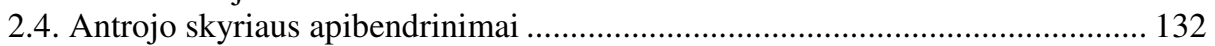

3. ŠIUOLAIKINĖS LIETUVOS ARCHITEKTŪROS STILIŲ IR KRYPČIŲ

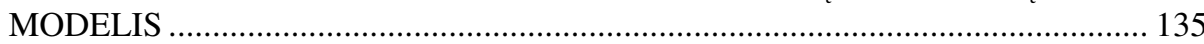

3.1. Modelio kūrimo teorinès prielaidos ir pagrịstumas .......................................... 135

3.2. Lietuvos architektūros stilių ir krypčių meninès raiškos modelis....................... 139

3.3. Šiuolaikinès Lietuvos architektūros meninè raiška pasauliniame kontekste ..... 142

3.4. Trečiojo skyriaus apibendrinimai ................................................................ 152

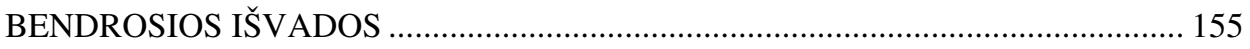

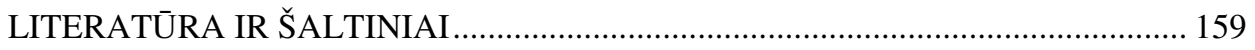

AUTORIAUS MOKSLINIŲ PUBLIKACIJŲ DISERTACIJOS TEMA SĄRAŠAS .. 171

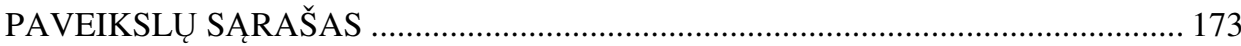




\section{Contents}

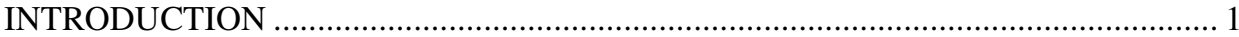

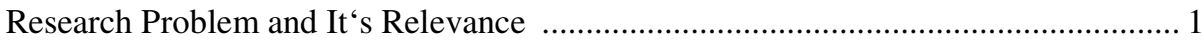

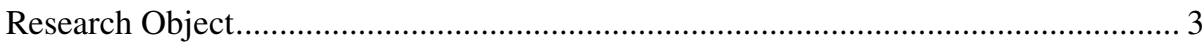

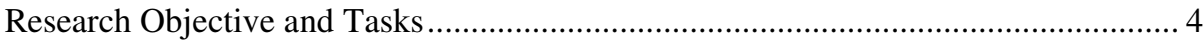

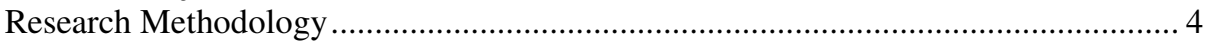

Research Boundaries and Directions .................................................................... 5

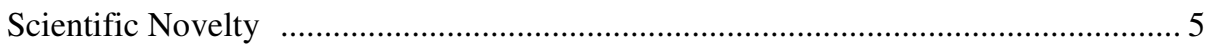

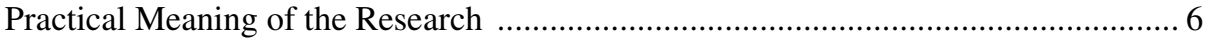

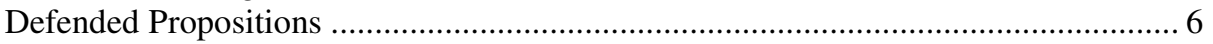

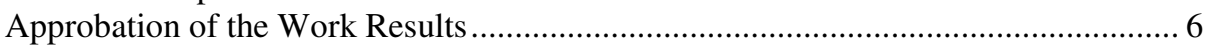

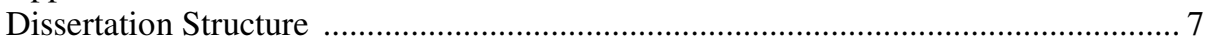

1. DEVELOPMENT OF MODERN LITHUANIAN ARCHITECTURE IN

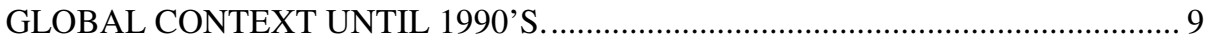

1.1. Similarities of Creative Values. Functional aesthetcs. ....................................... 11

1.2. Critical Regionalism and Aspect of Vernacular in Modern

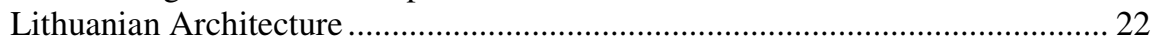

1.3. Means of Artistic Expression in Search of Plasticity and Sculptural Form......... 36

1.4. Summary of the First Chapter. ......................................................................... 52

2. ARTISTIC EXPRESSION OF GLOBAL ARCHITECTURAL STYLES IN CONTEMPORARY LITHUANIAN ARCHITECTURE (1990-2013)..................... 53

2.1. Technic Aesthetics and Surface Expression ....................................................... 55

2.2. Complex Expression of Post-Modernism. Historicism, Stylization

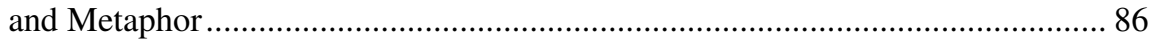

2.3. Tendencies of Deconstructyvism and Minimalism in Contemporary

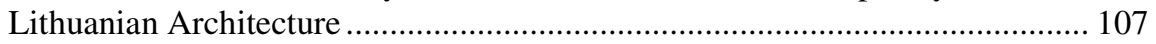

2.4. Summary of the Second Chapter .................................................................... 132 


\section{MODEL OF STYLES AND TRENDS IN CONTEMPORARY}

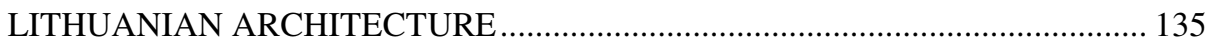

3.1. Theoretical Assumptions of the Model............................................................. 135

3.2. Normative model of styles and trends of contemporary Lithuanian architecture

3.3. Artistic Expression of Contemporary Lithuanian Architecture in

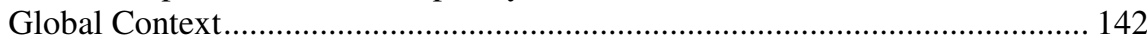

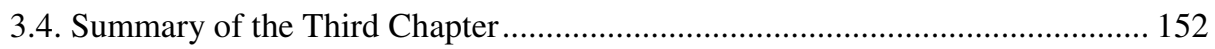

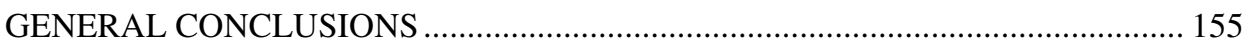

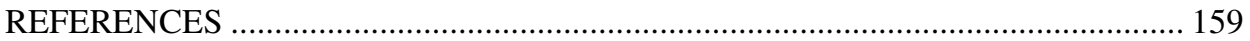

AUTHOR'S PUBLICATIONS ON THE DISSERTATION SUBJECT ....................... 171

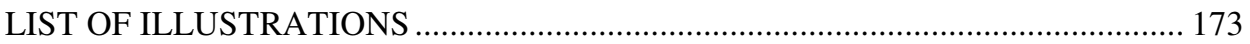




\section{Ivadas}

\section{Problemos formulavimas ir darbo aktualumas}

XX a. antrosios pusès architektūros objektų meninė raiška Lietuvoje nagrinejjama epizodiškai, dažnai gilinantis i vieną atskirą stilių ar kryptį, laikotarpi, objekto paskirti, naudojamas konstrukcijas ir pan. To pasekoje susiduriama su tyrimo objektyvumo problemomis, kadangi nagrinejant trumpą laikotarpį nèra ịvertinama raida ir tendencijos, nagrinejjant vieną konkretu stilių, nèra ịvertinami greta vykstantys reiškiniai ir procesai, taip pat dažnai nėra vertinama užsienio architektūros stilių įtaka.

Taigi, dèl menko ištirtumo yra nusistovejusi praktika Lietuvos moderniają architektūrą skirstyti taip pat kaip ir pasaulinę - $i$ tris pagrindinius etapus/stilius modernizmą, vèlyvaji modernizmą ir postmodernizmą. Ši praktika yra teisinga, tačiau architektūros objektų meninès raiškos ịvairovė kiekviename šių etapų yra didelè ir iki šiol neištirta, išsiskirianti i skirtingas kryptis, kurios dažnai veikia vieną objektą tuo pačiu metu, ir dažnu atveju skiriasi nuo pasaulinèje architektūroje vykusių procesų laiko atžvilgiu.

Moderniojoje Lietuvos architektūroje visuomet pažymima tarptautinio stiliaus įtaka, tačiau savitumo tyrimai apsiriboja regionalizmo kryptimi, menkai nagrinejjant jos sąlyti su funkcionalistine estetika, kontekstualumo klausimai dažnai nekeliami. Vèlyvojo modernizmo stiliaus tyrimai apsiriboja laikotarpiu iki 
Nepriklausomybės atgavimo, neįvertinant iki šiol aktualių techninès estetikos high-tech ir slick-tech krypčių. Lietuvos architektūroje postmodernizmo stilistika, dekonstruktyvistiniai formos kūrimo principai, turintys tiesioginès įtakos šiuolaikinei architektūrai, moksliniame lygmenyje apskritai nenagrinèti, dažnai apsiribojant stilizacijos ir istorinių elementų analize moksliniuose straipsniuose. Pakitę formos kūrimo principai, dažniausiai vykstantys skaitmeninèje erdvejje, tiek pasaulinèje, tiek Lietuvos architektūroje lemia kitokią architektūros objektų meninę raišką, kuri vis dèlto, taip pat yra įtakota ankstesnių architektūros stilių.

Pavienių stilių meninę raišką šiuolaikinèje Lietuvos architektūroje nagrinejjančiuose tiriamuosiuose darbuose sudètinga suvokti bendrą stilistinị kontekstą, todèl šiame darbe stiliai ir kryptys nagrinèjami kompleksiškai, suvokiant ir iliustruojant jų galimą ,persidengimą“. Darbas yra aktualus menotyriniu aspektu, tiriama problematika yra tiesiogiai susijusi su šiuolaikine architektūra.

Užsienio architektūrologijoje panašaus pobūdžio tyrimų yra atlikta nemažai. Kompleksiška vėlyvojo modernizmo ir postmodernizmo stilių meninès raiškos raida nagrineta $\mathrm{Ch}$. Jencks monografijose „Architecture today“, „,The Language of Post-Modern architecture“, „Late-Modern Architecture“ „The Story of PostModernism: Five Decades of the Ironic, Iconic and Critical in Architecture“, ,The New Moderns", „Critical Modernism. Where is Post-Modernism going?“, „Architecture 2000 and Beyond“, (1982; 1991; 1980; 2011; 1990; 2007; 2000a). Taip pat svarbią šiuolaikinès architektūros analizę raiškos priemonių atžvilgiu, yra atlikęs K. Frampton knygose „Modern Architecture. A Critical History“, „The Evolution of 20th-Century Architecture: A Synoptic Account“ (2007; 2006). A. Tzonis ir L. Lefaivre atlikta apžvalga „Architecture in Europe Since 1968. Memory and Invention“ ypatingai naudinga dèl išsamios konkrečių objektų menotyrinès analizès. Svarbūs jų atlikti tyrimai regionalizmo tema (2003; 2011). Postmodernistinès architektūros meninè raiška nagrinèjama R. Venturi „Complexity and Contradiction in Architecture“, taip pat R. Venturi, D. S. Brown ir S. Izenour „Learning from Las Vegas“ (1966; 1972), Ch. Jencks „What is PostModernism“, „Post-Modernism, The New Classicism in Art and Architecture“ (1986; 1987).

Šiuolaikinès architektūros objektų meninès raiškos priemones nagrinejja Ph. Jodidio (2001), Ch. Jencks (1997). Naujas raiškos galimybes pristato P. Schumacher „The Autopoiesis of Architecture: A New Framework For Architecture“ (2011; 2012). Architektūros teorijos straipsnių rinkiniai, padèję ivertinti kiekvieno laikotarpio architektūrinių idèjų kompleksiškumą, ir kiekvienos atskiros tendencijos idèjinị foną būtų H. F. Mallgrave „Architectural Theory, vol II. An Antologhy from 1871-2005“, taip pat H. F. Mallgrave ir D. Goodmann „An Introduction to Architectural Theory. 1968 To the Present“ 
(2008; 2011). N. Leach sudarytas „,Rethinking architecture; A Reader in Cultural Theory“ (2007), M. K. Hays „Architecture Theory Since 1968“ (1998).

Svarbus Lietuvos moderniosios architektūros tyrimas atliktas V. Petrulio, M. Drèmaitès ir V. Tutlytès „Architektūra sovietinèje Lietuvoje“ (2012), kur nagrinejjama modernioji Lietuvos architektūra iki Nepriklausomybès atgavimo. Šioje knygoje svarbus objektų katalogas, pažymejjęs visus svarbiausius to meto architektūros objektus, surinkta svarbi iliustracinè medžiaga, ịvardintos svarbesnès moderniosios architektūros kryptys. Ši laikotarpi V. Petrulis taip pat nagrinejja moksliniuose straipsniuose (2005; 2006; 2007). Šiuolaikinès Lietuvos architektūros apžvalgą, tiesa daugiau socialiniu - kultūriniu aspektu, atliko T. Grunskis ir J. Reklaite knygoje „Laivès architektūra“ (2012). Pažymètini apžvalginiai šiuolaikinès architektūros leidiniai būtų R. Buivydo „Architektūra: pozityvai ir negatyvai“ (2006), „Vilniaus architektūros gidas“ (1900-2005 ir 1900-2012 m.) (2005; 2012). Pavienių XX a. architektūros stilių ir krypčių analizè pateikta A. Mačiulio straipsniuose (1993; 1996; 1999; 2002; 2004; 2008) taip pat vadovèlyje „Architektūra. Stiliai, kompozicija, menų sąveika“ (1997).

Atskirų architektūros krypčių tyrimuose išsiskiria L. Nekrošiaus daktaro disertacija „Struktūralizmo idejos šiuolaikinèje Lietuvos architektūroje“ nagrinèjanti struktūralizmo apraiškas moderniojoje Lietuvos architektūroje iki šių laikų, taip pat straipsniai (2006a; 2006b). Šią temą yra tyrinèjęs ir R. Buivydas (2004a; 2004b; 2006b). Svarbius tyrimus yra atlikęs K. Lupeikis (2001; 2002; 2004; 2005; 2007) kur nagrinèjami minimalizmo raiškos bruožai šiuolaikinèje architektūroje. Šiam tyrimui naudingi R. Buivydo straipsniai „XX a. architektūra: istorizmas“ ir „XX a. architektūra: iracionalizmas“ (1999a; 1999b).

Pavienių architektūrinès raiškos tendencijų tyrimai menotyriniu aspektu pastebimi ir J. Vanago tyrime „Miesto teorija“ (2003), J. Palaimos „Harmonija architektūroje: proporcijos ir mastelis“ (2006), A. Mačiulio „Dailè architektūroje“ (2003), A. Stasiulio „Forma architektūroje“ (2010) , A. Gabréno mokslinèje disertacijoje „Medis šiuolaikinèje architektūroje“ (2012).

Naudingos pavienių autorių kūrybos principu analizès nagrinèjamos biografinèse knygose, A. Mačiulio „Architektai Algimantas ir Vytautas Nasvyčiai“ (2007), „Vytautas Edmundas Čekanauskas“ (2011), „Architektai Simonas ir Gytis Ramuniai“ (2004). Taip pat ir straipsniuose - K. Gerliako „Gediminas Baravykas: asmenybė ir kalba“ (1996a), „V. E. Čekanausko projektuotų pastatų apžvalga“" (1993).

\section{Tyrimo objektas}

Tyrimo objektas yra pasaulinès architektūros stilių, meninè raiška Lietuvos architektūroje. Remiantis panašaus pobūdžio užsienio tyrinètojų darbais, 
nustatomi atskiri pasaulinės architektūros stilių ir krypčių meninès raiškos bruožai Lietuvos architektūroje. Tyrimo pabaigoje, remiantis išnagrinèta medžiaga ir objektais, sukuriamas meninès raiškos bruožais paremtas, stilių ir krypčių skirstymo modelis, ịvertinantis skirtingos meninès raiškos objektų paplitimą šiuolaikinèje Lietuvos architektūroje. Grafinè stilių ir krypčių modelio išraiška padeda nustatyti kūrybinių principų sąsajas ir ,persidengimą“, rodo jų vystymąsi laike, tuo pačiu leidžia stebèti stilistinị kontekstą.

\section{Darbo tikslas ir uždaviniai}

Darbo tikslas yra įvertinti pasaulinès architektūros stilių meninès raiškos įtaką šiuolaikinei Lietuvos architektūros raiškai, ịvertinti jų paplitimą ir ryšius tarpusavyje, nurodyti vystymosi tendencijas. Siekiant tyrimo tikslo, keliami tokie uždaviniai:

1. Aptikti ir identifikuoti užsienio architektūros kryptis, įtakojusias Lietuvos moderniają architektūrą iki 1990-ujų:

- nustatyti jų raiškos bruožus, savitumus, paplitimą;

- $\quad$ susieti jas su šiuolaikine architektūra.

2. Apžvelgti skirtingų architektūros krypčių meninès raiškos įvairovę 19902013 m.:

- nustatyti jų raiškos bruožus, savitumus, paplitimą;

- nurodyti tendencijas.

3. Sukurti normatyvini stilių ir krypčių skirstymo modeli kuriame atsispindètų išnagrinèti objektai, padèsiantị ịvertinti šiuolaikinès Lietuvos architektūros stilių ir krypčių meninès raiškos kontekstą.

\section{Tyrimo metodika}

Kiekvienas I ir II dalies skyrius yra sudarytas remiantis tuo pačiu principu. Vadovaujantis analitiniu lyginamuoju metodu, kiekvieno skyriaus pradžioje yra pateikiami, teorine medžiaga paremti, konkrečios architektūrinès krypties ar stiliaus raiškos bruožai, kurie vèliau yra nagrinèjami lyginamosios analizės būdu, siekiant ịvertinti tam tikros architektūrinès krypties paplitimą Lietuvos architektūroje. III-ojoje dalyje aprašomas stilių ir krypčių skirstymo modelis, kuriamas vadovaujantis normatyviniu raidos tyrimu, aprašytu Pentti Routio (2007).

Tyrime remiamasi rašytiniais šaltiniais, iliustracijų ir brěžinių analize, natūriniais empiriniais tyrimais, objektų fotofiksacijomis. Išvados pateikiamos susisteminus ir apibendrinus gautą medžiagą ir įvertinus tyrimo rezultatus. 


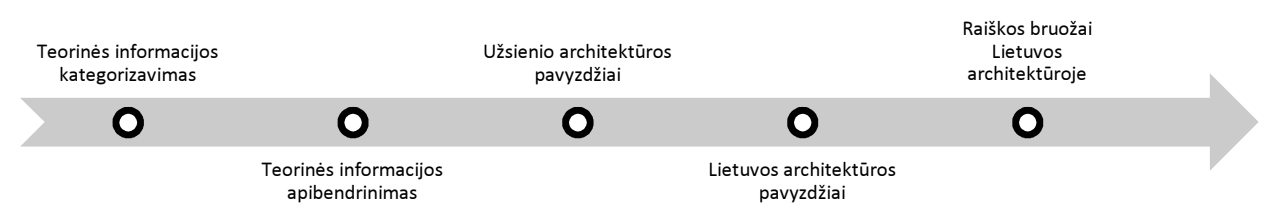

1 pav. Principinè tyrimo schema

Fig. 1. Principle scheme of research

\section{Tyrimo ribos ir kryptys}

Siekiant didesnio darbo aktualumo, tyrime nagrinejami tik tie architektūriniai stiliai ir kryptys, kurie turi tiesioginès įtakos šiuolaikinès Lietuvos architektūros meninei raiškai (maždaug nuo XX a. 6 deš.). Dèl menko ištirtumo, daugiausia dèmesio skiriama architektūros krypčių tyrinejjimui nuo 1990-uјjų, tačiau siekiant ivertinti kontekstą kuo platesniu mastu, apžvelgiami anksčiau atlikti tyrimai, analizuojantys stilistinę Lietuvos moderniosios architektūros raidą. Tyrime stiliai ir kryptys analizuojami išskirtinai meninès raiškos požiūriu, sociokultūriniai stilių paplitimo aspektai trumpai apžvelgiami kiekvieno skyriaus pradžioje.

Šiuo tyrimu nėra siekiama inventorizuoti visų šiuolaikinès architektūros kūrinių, taip pat nèra siekiama paminèti visų šiuo metu kuriančių autorių. Darbe naudojamais pavyzdžiais siekiama iliustruoti charakteringiausias šiuolaikinès Lietuvos architektūros meninès raiškos tendencijas, turinčias ịtakos šiuolaikiniams formos kūrimo principams. Surinkta informacija kategorizuojama remiantis kokybiniais, o ne kiekybiniais parametrais, vèliau apibendrinama nurodant tam tikros kategorijos panašumus, kurie, remiantis užsienio architektūros objektais, lyginami su vietiniais. Tokiu būdu nustatomi konkretaus stiliaus ar krypties meninès raiškos bruožai Lietuvos architektūroje.

\section{Darbo mokslinis naujumas}

Šiam darbui aktualius tyrimus ir apžvalgas Lietuvos architektūrinès raiškos tema galima būtų suskirstyti ị kelias grupes:

1. Tyrimai aprašantys bendrus meninès raiškos bruožus tam tikro laikotarpio Lietuvos architektūroje.

2. Vieno iš architektūros stilių ar krypčių analizè ir jos įtaka šiuolaikinei Lietuvos architektūrai. 
3. Tyrimai susiję su konkrečios paskirties pastatų (pramoninių, sakralinių, gyvenamųjų ir kt.) menine raiška, ar konkrečių konstrukcijų bei medžiagų naudojimu šiuolaikinejje Lietuvos architektūroje.

4. Darbai nagrinejantys sociokultūrines, politines ir kitas itakas šiuolaikinejje Lietuvos architektūroje.

Išsamaus, kompleksiškai nagrinėjančio šiuolaikinès Lietuvos architektūros meninès raiškos tendencijas, prieš tai buvusių stilių įtakas šiuolaikinei architektūros meninei raiškai, bei jų sąveikas tarpusavyje, tyrimo iki šiol atlikta nebuvo.

\section{Darbo praktinè reikšmè}

Praktinès kuriamo stilių ir krypčių modelio panaudojimo galimybės numatomos edukaciniais ir tolimesnių meninès raiškos tyrimų tikslais. Edukacijoje svarbus bendro architektūrinio konteksto pateikimas, grafini modelị dèkinga lyginti su kitų meno sričių raidos modeliais, numatant galimas sąsajas. Tokiu būdu architektūra nagrinèjama tarpdiscipliniškai, siejant ją su kitomis meno sritimis. Architektūros stiliai ir kryptys svarbios ir kitų mokslo šakų ir kypčių, pavyzdžiui, istorijos, kultūrologijos tyrinètojams.

\section{Ginamieji teiginiai}

1. Architektūros stiliai ir kryptys, būdingi užsienio architektūrai, vienu ar kitu laikotarpiu reiškèsi ir Lietuvos architektūroje, tačiau skyrèsi meninès raiškos būdai ir paplitimo laikotarpis.

2. Modernistinè ir vèlyvojo modernizmo Lietuvių architektūra rèmèsi beveik identiškomis meninès raiškos priemonėmis kaip ir užsienio, tačiau lygiagrečiai kūrè ir savitą, regionalią kryptį.

3. Postmodernistinès architektūros meninè raiška Lietuvoje plito fragmentiškai, dažniausiai istorinių formų stilizacijos pavidalu.

4. Šiuolaikinèje Lietuvos architektūroje matomi formos kūrimo principai paremti pasaulinès architektūros meninės raiškos tendencijomis.

\section{Darbo rezultatụ aprobavimas}

Disertacijos tema yra atspausdinti 3 moksliniai straipsniai recenzuojamuose mokslo žurnaluose, perskaityti 2 pranešimai mokslinèse konferencijose ir 2 pranešimai seminaruose. 
- „4D architektūroje“, tarptautinèje mokslinèje konferencijoje „Menų sąveika architektūroje 2011“,Vilniuje.

- „Struktūra ir forma šiuolaikinèje Lietuvos architektūroje“, tarptautinejje mokslinèje konferencijoje „K. Šešelgio skaitymai 2012“, Rokiškyje.

- „Fasadų transformacijos medijų pagalba“ seminare „Medijų menas ir komunikacija 2012“, Vilniuje.

- „Šiuolaikiniai architektūrinès formos kūrimo principai“ seminare „Šiuolaikinis dizainas skaitmeninejje erdvèje 2013“, Vilniuje.

\section{Darbo struktūra}

Disertaciją sudaro ịvadas, trys skyriai, bendrosios išvados, naudotos literatūros ir autoriaus mokslinių publikacijų disertacijos tema sąrašas bei iliustracijų sąrašas.

Darbo ivadineje dalyje aptariama tiriamoji problema ir jos aktualumas, ištirtumas Lietuvoje ir užsienyje. Nustatomas tyrimo objektas ir tikslas, iškeliami uždaviniai tikslui pasiekti, numatomos tyrimo ribos ir kryptys, apibrěžiama naudojama metodika, nurodomi pagrindinių terminų apibrèžimai. Suformuluojami ginamieji teiginiai.

Pirmasis disertacijos skyrius skirtas Lietuvos moderniosios architektūros raidos analizei iki 1990-ųjų, užsienio architektūros stilių ir krypčių Lietuvos architektūroje apžvalgai. Antrajame disertacijos skyriuje nustatomi užsienio architektūros stiliai ir kryptys Lietuvos architektūroje nuo 1990-ujų, taip pat jų galima itaka architektūros tendencijoms. Trečiasis tyrimo skyrius skirtas norminio raiškos modelio teoriniam pagrindimui, grafiniam jo išpildymui bei gautiems rezultatams aprašyti, taip pat palyginimui su panašaus pobūdžio tyrimais. Darbo pabaigoje pateikiamos tyrimo išvados. Bendra disertacijos apimtis - 182 puslapiai, 235 iliustracijos, ir 3 lentelès. Tyrime panaudoti 189 literatūros šaltiniai. 



\section{1}

\section{Moderniosios Lietuvos architektūros raida pasauliniame kontekste iki 1990 m.}

Šiame skyriuje nustatomi užsienio architektūros stiliai ir kryptys, įtakoję Lietuvos moderniają architektūrą iki 1990-ujų metų, siekiama nustatyti jų meninès raiškos bruožus, savitumus, paplitimą, bei susieti juos su šiuolaikine Lietuvos architektūra. Analizuojant Lietuvos ir užsienio moderniają architektūrą meninès raiškos aspektu, gretinant pavienius architektūros objektus laike, reikia turèti omenyje sudètingą Lietuvos politinę, socialinę ir kultūrinę situaciją aptariamu laikotarpiu, kuri sąlygojo stilistinị architektūros evoliucijos savitumą. Bendrame architektūros vystymosi ir raidos kontekste išsiskiria visas XX amžius. Tokio dinamiškumo ir kaitos per vieną šimtmetị nebuvo niekada anksčiau.

Stilistinè architektūros raida laisvajame, demokratiniame pasaulyje buvo koreguojama socialinių santykių, menininkų idèjų, ekonominių veiksnių, kai kurie sprendimai diktuojami korporaciju ar didelių verslo grupių. Sovietu sajungoje - išskirtinai politinès santvarkos (Petrulis 2012a). Politika naudojo meną kaip būdą manipuliuoti visuomene, demonstruoti galią, pabrežti nedidelio žmogaus ir didelès sistemos santykị. V. Petrulis, politinį ir ideologini faktorių vertina kaip vieną esminių sovietinès architektūros formantų: ,,_..> prabilus apie sovietmečio architektūrą, tenka pripažinti, kad politinis užsakymas, ideologiniai 
aspektai čia užima kiek svaresnę poziciją nei ịprastai. Iš pradžių šie objektai tapo svarbiu sovietmečio ideologų irankiu, o vèliau, posovietiniu laikotarpiu, taip pat neišvengè politizuoto vertinimo, šị kartą žvelgiant iš priešingos barikadų pusès. Tad turint omeny gan specifinę Sovietų Sajungos patirtị, politinis - ideologinis imperatyvas neabejotinai iškyla kaip vienas ryškiausių to laikmečio architektūrą itakojančių sociokultūrinių veiksnių“ (Petrulis 2012a). Tas pats funkcionalizmas Europos šalyse prasidejo nuo filosofijos, meno, muzikos, netgi fizikos mokslo proveržio (Lupeikis 2011), o sovietinis - remiantis socialinès plètros reikalavimais, utilitariniu požiūriu. Netgi premijos (Lenino, Valstybinè, Ministrų tarybos) buvo skiriamos ne tiek už objektų menini, architektūrinį išpildymą, kiek už to laikmečio politinių nuostatų atitikimą (Nekrošius 2008).

Tik politinès priežastys lèmè tai, jog architektūros istorikai stalinistinei architektūrai atiduoda išskirtinai pirmaji pokario dešimtmetį, kuriame vienintelis tuo metu priimtinas architektūros stilius - retrospektyvinis istorizmas, visais būdais ,importuojamas“ ir diegiamas tuometinès valdžios. Tie patys politiniai sprendimai, priimti Sovietų sajungoje šeštojo dešimtmečio viduryje, smerkiantys pompastiškumą ir dekoratyvumą, lemė architektūros racionalizavimą pačiomis pigiausiomis ir paprasčiausiomis priemonèmis. Tai, kas Vakarų Europoje vyko laipsniškai, paraleliai siūlant kitokias architektūros raidos koncepcijas, Sovietų Sajungoje buvo sprendžiama ideologizuotai ir politizuotai (Petrulis 2006). Jokiu būdu negalima teigti, jog tokie sprendimai buvo priimti atsižvelgiant i pasaulinés architektūros tendencijas, ar noru pakelti bendrą sajungos architektūros lygị: „Socialistinio realizmo architektūros politinis aspektas kur kas architektūriškesnis: jis pasireiške masteliu, dekoratyvumu, reprezentatyvumu, o modernizacijos laikotarpio architektūros politika akcentuoja masiškumą ir pigumą" (Petrulis 2006). Suprantama, nepaisant pragmatiškų motyvų, čia atsirado vietos ir ideologijai. Moderniosios architektūros saikingumas, funkcionalumas ir paprastumas kur kas labiau atitiko sovietmečio dvasią, nei socialistinio realizmo dekoratyvumas, na o dauguma hiperbolizuotos meninès raiškos, vėlyvojo modernizmo laikotarpiu kurtų visuomeninių pastatų - tai tuometinès valdžios noras pasipuikuoti, išaukštinti socializmo laimèjimus, parodyti neegzistuojantị santvarkos klestèjimą.

Sąlygos kurti ir realizuoti tokius objektus buvo suteikiamos išskirtinès, lyginant su eiliniais gyvenamaisiais, ar mažos reikšmès visuomeniniais pastatais. Tokie reprezentaciniai pastatai būdavo aprūpinami kokybiškesnèmis medžiagomis, geresniu finansavimu, tačiau vis tiek statybos dažnai dèl vienokių ar kitokių politinių ar ekonominių faktorių užsitęsdavo. Nepaisant išskirtinio valdžios dèmesio reprezentaciniams objektams, ribotas vietinių medžiagų pasirinkimas, iki galo nepatikrinti inžineriniai sprendimai skatino architektus leistis ị kompromisus, ieškoti savitų sprendimų. Tarkime, Šiuolaikinio meno centras (archit. V. E. Čekanauskas 1967 m.) Vilniuje, tuo metu buvo įvardinamas 
kaip reprezentuojantis Sovietų Lietuvos laimejjimus, tačiau tuo pačiu priminè kuklų Suomių modernizmą (Buivydas 2006). Po pragmatiškojo funkcionalistinio laikotarpio modernistinèje architektūroje daugejjo tradiciškumo, regionalizmo tendencijų, ieškant nacionalinio charakterio architektūroje. XX a. paskutiniojo dešimtmečio pradžioje, ịvykus staigiam epochų lūžiui turèjusiam įtakos visoms visuomenès gyvenimo sferoms, atotrūkis dar labiau išaugo (Drèmaitė 2012).

Nepaisant aptartų ideologinių nuostatų įtakos architektūrinių objektų meninei raiškai, reikètų atsižvelgti ị vieną unikalų aspektą, būdingą Sovietų sajungos šalims. Tos pačios idèjos, būdingos tiek Vakarų Europos, tiek sovietinio bloko šalims, galejo reikšti visiškai skirtingus dalykus, nors galutiniame rezultate architektūrinejje formoje, to nematyti. V. Petrulio teigimu, ,siekiant objektyviau ivvertinti sovietmečio architektūros politinès indoktrinacijos lygi, svarbu ne tik atpažinti tiesiogines ar netiesiogines architektūros politizavimo apraiškas, tačiau tuo pat metu suvokti, kad sovietmečio ideologų bandymai sukurti utopinę komunizmo santvarką bei socialistini miestą betarpiškai siejasi su bendrosiomis XX a. architektūros teorijomis bei ideologijomis“ (Petrulis 2010). Vertinant sociokultūrinius, politinius kontekstus modernistinèje architektūros sroveje, reikia atkreipti demesį, kad iš principo pats modernizmas yra daugiau socialinis ir kultūrinis projektas, kuris reiškèsi tarpdiscipliniškai, apimdamas visus kultūrinius reiškinius. Taigi, nors ir savaime suprantama, jog modernizmas Lietuvoje buvo padiktuotas bendrų vidinių Sovietų sajungos procesų, tačiau nebuvo uždaras, o daugiau atspindejo pasaulines modernizmo tendencijas (Petrulis 2012a).

\subsection{Vertybiniai - idèjiniai kūrybos panašumai. Funkcinè estetika}

Architektūros tyrinètojas K. Frampton pirmuosius žingsnius moderniosios architektūros link įžvelgia XVII a. viduryje, kuomet prancūzų architektas Claude Perrault atskyrė architektūros ir konstrukcijų sąvokas, taip tarsi mesdamas iššūkị universaliai Vitruvijaus architektūros filosofijai. Po švietimo laikotarpio modernioji architektūra gyvavo dvejose skirtingose plotmèse, avangardistinèje ir utopinèje, pastarają puikiai iliustruoja Claude Nicolas Ledoux darbai. Tai taip pat buvo sąlygota tuometinès pramonès revoliucijos, didelès migracijos, iš to išsivystančių urbanizacijos procesų. Industrinè mašinomis pagrịsta produkcija buvo nauja, o tai skatino totalaus urbanistinio planavimo ir industrializavimo utopijas (Frampton 2007). H. F. Mallgrave moderniosios architektūros atsiradimo prielaidas įžvelgia XIX a. pabaigos JAV ekonominiuose pokyčiuose, susijusiuose su gyvenimo kokybès kilimu, spartejjančiu gyvenimo tempu, mechanizacija ir didejjančiu gyventojų mobilumu (Mallgrave 2008). 
Šiam tyrimui svarbi vėlesnè moderniosios architektūros kryptis - tarptautinis stilius (angl. International style) ${ }^{2}$, pirmą kartą įvardintas XX a. trečiajame dešimtmetyje, o Lietuvoje (išskyrus kelias apraiškas tarpukario architektūroje) issitvirtinęs šeštajame dešimtmetyje.

Pagrindiniai tarptautinio stiliaus meninès raiškos principai. $\mathrm{XX}$ a. trečiajame dešimtmetyje tarptautinis stilius dar neturèjo savo pavadinimo, tačiau to meto publikacijose aptinkamas „naujosios architektūros“ terminas leidžia daryti prielaidą, jog pokyčiai architektūrinès formos kūrimo procese buvo akivaizdūs. Adolf Behne publikacijoje „The Modern Functional Building“ (1926 m.) išdèsto ganètinai pragmatiškas modernaus ir funkcionalaus pastato projektavimo gaires teigdamas jog: , <...> architekto užduotis - subalansuoti erdvių santykius tarpusavyje pagal jų paskirtį, nekreipiant dèmesio i jokius kitus faktorius. Tik tuomet galima siekti sukurti pastatą, kuriame susilieja interjero ir eksterjero erdvès, išsidèsto aukštai, kuriame parenkamas geriausias erdvinis scenarijus, geriausia šviesos sklaida, kuriame vidinès erdvès pereina ị sodą, iš jo i gatvę ir tampa transporto srautu. Tokio pastato projektavimo procese visos simetrijos ašys, visas geometriškumas, visa planinè ornamentika išnyksta architektūra tampa realių formų visuma." (Behne 2008). Walter Curt Behrendt publikacijoje „The Victory of the New Style“ (1928 m.) jau išskiria kelis svarbius „naujosios architektūros“ kūrimo aspektus, kurie turèjo reikšmingos įtakos tuometiniams projektavimo principams:

- nauji technologiniai laimejjimai (statybinè technika, naujos konstrukcijos) sąlygojantys ekonominius pokyčius statyboje, įtakojantys tempą ir mastus;

- išskiriamos naujos medžiagos (metalas, betonas, stiklas), kurios įtakoja tiek konstruktyvinius sprendimus, tiek medžiagiškumą.

Minètoje publikacijoje W. C. Behrendt pastebi, jog pokyčiai statybos technologijoje sutrikde nusistovejjusius projektavimo principus, buvusią pastato ir jo erdvių pusiausvyrą. Naujų konstrukcijų įtakos mastus architektūrinės formos meninei raiškai autorius lygina su gotikinio kupolo atsiradimu viduramžiais (Behrendt 2000).

1927 m. publikuotas Le Corbusier ir Pierre Jeanneret straipsnis „Five Points for a New Architecture" nagrinėja naujų kūrybos principų meninę raišką, analizuodami naudojamus architektūrinius elementus, autoriai apibrěžia kelis svarbius naujosios architektūros meninès raiškos požymius:

Atramos (pakelia pastatą virš žemès paviršiaus, sukuria nesvarumo efektą, leidžia naudotis erdve atsiradusia po namu).

\footnotetext{
${ }^{2}$ Kaip jau minèta ịvadinejje dalyje, šiame tyrime tarptautinis stilius laikomas viena iš moderniosios architektūros krypčių.
} 
- Eksploatuojamas stogas (dažniausia įrengiant sodą ar apželdinant, tokiu būdu reguliuojant mikroklimatą patalpose, dengtose plokščiu stogu).

- Laisvas erdvių planavimas (kolonų tinklas leidžia atsisakyti laikančių sienų naudojant pageidaujamo storio pertvaras).

- Horizontalus langas (atsisakius laikančių sienų, lauko atitvaros gali būti stiklinès, kurių ilgis dažniausiai didesnis nei aukštis).

- Laisvas fasado planavimas (naudojant kolonų tinklą fasadas atitraukiamas nuo laikančio pastato karkaso, taip atsiranda galimybė laisvai planuoti fasado plokštumas) (Le Corbusier et al. 1970).

1932 m. vykusi tarptautinè architektūros paroda Niujorko modernaus meno muziejuje atskleidè tuometines architektūros tendencijas. Alfred H. Barr parodos kataloge naujają architektūros krypti pavadina tarptautiniu stiliumi ir išdèsto pagrindinius šios krypties meninès raiškos bruožus:

- Naujasis stilius akcentuoja tūri ir erdves, kurios yra atskirtos sienomis. Pastatas yra skeletas, jam formą suteikia laisvai išdèliojamos pertvaros.

- Taisyklingumas ir laisvumas. Taisyklingumas pasireiškia horizontalia ir vertikalia konstruktyvinių elementų ritmika, kuri kartais suardoma architektūriniais akcentais (laiptatakiais, kaminais, evakuaciniais išèjimais), padiktuotais laisvo planavimo principų.

- Puošybos elementu ir ornamentikos atsisakymas. Visos medžiagos, matomos fasaduose atlieka kokią nors funkciją. Pastato estetiką lemia šių elementų tarpusavio ryšiai (Barr 2008).

Naujajai krypčiai reikšmingą įtaką padare De Stijl judèjimas. Remdamasis šios meno krypties principais Theo van Doesburg (1924 m.) paskelbe 16 naujosios architektūros požymių, iš kurių išskiriame svarbesnius, meninės raiškos požiūriu. Būtent De Stijl dèka tarptautinio stiliaus ideologijoje atsirado savotiška laiko ir erdvès interpretacija, nuosaikus spalvos ir medžiagų faktūrų panaudojimas, ankstesnei architektūrai nebūdingo kintančio silueto samprata:

- Nauja forma. Skirtingai nei prieš tai buvę, neadaptavo prieš tai buvusių idèjų. Naujasis stilius siūlo visiškai naują formą.

- Elementarus. Naujasis stilius - lengvai suvokiamas ir paprastas, susidedantis iš elementarių elementų. Tai tūris, funkcija, plokštuma, laikas, erdvè, šviesa, spalva ir medžiaga.

- Funkcionalus.

- Ekonomiškas.

- Neakcentuojantis formos. Naujasis stilius neturi atpažistamo silueto, todèl yra paslankus ir lengvai adaptuojamas.

- Plastiškas. Lengvai kintančios, lengvos formos yra priešprieša prieš tai buvusiems monumentalumu pasižymintiems architektūros stiliams.

- Atviras. Pastatas yra erdvé, kuri yra suskirstyta sienomis pagal tam tikrus funkcinius poreikius. 
- Laikas. Naujosios architektūros laisvumas ir ekspresyvumas aprèpia laiko sąvoką. Trijų dimensijų erdvé pasipildo ketvirtaja - laiko.

- Spalva. Naujojoje architektūroje spalva organiškai įsilieja ị pastatą kaip papildoma medžiaga ar menininko paveikslas. Kitu atveju spalva taptu dekoratyvi, o tai prieštarauja sekančiam požymiui.

- Nedekoratyvus.

- Sintezè. Naujoji architektūra nèra reprezentatyvi, todèl jos meninè raiška sutelkta bendroje kompozicijoje (Doesburg 1974).

Panašius kūrybos principus deklaravo ir Mies van der Rohe tekstuose „Dangoraižiai“" (The Skyscrapers) (Van der Rohe 1991) ir „Biurų pastatas“ (The Office Building) (Van der Rohe 1991).

Iš pateiktų apibūdinimų galima apibendrinti (1 lentelè) pagrindinius tarptautinio stiliaus kūrybinius principus, meninès raiškos bruožus, medžiagiškumą:

1 lentelè. Pagrindiniai tarptautinio stiliaus meninès raiškos bruožai pagal W. C.

Behrendt, Le Corbusier, A. H. Barr ir T. Van Doesburg.

Table 1. Basic features of artistic expression of International style, according to W. C. Behrendt, Le Corbusier, A. H. Barr ir T. Van Doesburg.

\begin{tabular}{|l|l|l|}
\hline Principai & Meninė raiška & Medžiagiškumas \\
\hline Erdvių formavimas & Elementarus & Betonas \\
\hline Laisvas planavimas & Nedekoratyvus & Metalas \\
\hline Struktūros ritmika & Monochromiškas & Stiklas \\
\hline Funkcionalumas & $\begin{array}{l}\text { Funkcionalūs } \\
\text { akcentai }\end{array}$ & Aliuminis \\
\hline Ekonomiškumas & Funkcinè estetika & Marmuras \\
\hline Laiko dimensija & & Granitas \\
\hline
\end{tabular}

Tarptautinio stiliaus ịsitvirtinimo Lietuvos architektūroje prielaidos. Pirmoje XX a. puseje, Vakaru Europoje ir JAV vyravęs modernizmas Sovietų sajungoje ir aplinkinèse respublikose igavo visiškai kitoki kontekstą. Prie jau aptarto politinio konteksto prisidejo socialiniai faktoriai. Sparčiai augantys miestai (tendencija buvo pastebima ne tik Sovietų sajungoje, bet ir kitose šalyse, tokiose kaip Švedija, Suomija, buv. Vokietijos Federacinè Respublika ir kt.) susidūrè su rimtomis, žmonių migracijos iš kaimų i miestus sukeltomis apgyvendinimo problemomis. Ypatingai tai buvo jaučiama atšiauresnio klimato 
regionuose, kuriuose statybos negalejo vykti ištisus metus. Unifikuoti stambiapaneliai gyvenamieji namai, surenkami iš jau statybos kombinatuose paruoštų elementų puikiai tiko šiai problemai spręsti. Tarptautinis stilius atitiko tuometinius socialinius ir ekonominius SSRS reikalavimus, vietiniai architektai adaptavo modernistų propaguojamą gelžbetonio kultūrą (Nekrošius 2008).

Reikšminga įtaka architektūrinei raiškai pasižymèjo ir tuometiniai mokslo laimejjimai. Atominiai bandymai, dalelių fizika, žmogaus kelionès ị kosmosą, kibernetika, informacinių technologijų sklaida keitè požiūrị i architektūrą. Atsirado nuostatos, jog architektūrą galima standartizuoti, apspręsti žmonių gyvenimo modelius ir juos pritaikyti realybejje (Nekrošius 2008). Miestų ir gyvenviečiu planavime pradèti plačiai taikyti unifikuoti gyvenviečių užstatymo modeliai. Tai nebuvo Sovietų sajungos išradimas, tokie kaiminystės vienetai taikyti tiek Vakarų Europoje, tiek JAV. 1933-aisiais, tarptautiniame moderniosios architektūros kongrese (pranc. Congres Internationaux D‘architecture Moderne (CIAM)) Le Corbusier teigè: , <...> daugiau negalima planuoti miestų remiantis estetiniais principais. Miestų planavimas turi būti funkcionalus iš principo. Miestų planavimas turi spręsti pirminius poreikius, kurie yra:

- apgyvendinimas;

- darbas;

- poilsis.

Planuojant miestus yra svarbu:

- žemès ploto panaudojimas;

- eismo organizavimas;

- istatymai ir potvarkiai.“ (Le Corbusier 1977).

Dèl planinès ekonomikos, privačios nuosavybès nebuvimo, dèl deklaruojamo bendruomeniškumo, Sovietų sajungoje jų taikymas tapo priimtinas dèl susiklosčiusios socialinès santvarkos (Vanagas 2003). J. Vanago teigimu: „visuose didesniuose Lietuvos miestuose sovietmečiu pagal šiuos kanonus buvo pastatyta daug gyvenamujų kompleksų. Nepaisant griežtų ekonominių reikalavimų ir labai riboto pastatų tipinių projektų skaičiaus, gabūs krašto urbanistai ir architektai sukūré nemažai gyvenamujų rajonų, pelniusių ir aukštus buv. SSRS apdovanojimus bei premijas, ir tarptautini pripažinimą. Tarp jų pirmiausia minimi Vilniaus Lazdynų, Žirmūnų rajonai, Kauno Kalniečių rajonas““ (Vanagas 2003). Dabar tokie urbanistiniai sprendimai vertinami diskretiškiau (Samalavičius 2011).

Septintojo dešimtmečio antrosios pusès architektūroje maksimaliai atsisakyta estetinių architektūros tikslų, suteikiant jai grynai funkcinę - utilitarią paskirtí. Šiuo laikotarpiu suprojektuota daugybè tipiniu gyvenamujų namų, darželių, kultūros namų ir kt., neturinčių jokios meninès vertès (Lupeikis 2002). Kita vertus, šioje tipinių, niekuo neišsiskiriančių pastatų masèje galima aptikti ir keletą išskirtinių, tarptautinès architektūros kūrybos principus atitinkančių objektų. V. 
Petrulio teigimu: ,šiuos ankstyvuosius ir svarbiausius industrinio sovietmečio modernizmo objektus galima vertinti žvelgiant pro modernizmo idejų prizmę, suvokti kaip savitą tarptautinio modernizmo stiliaus variaciją, kaip mažą tuometinès architektūros revoliuciją“ (Petrulis 2006). Šiems pastatams būdingos tuo metu vyravusios išraiškos priemonès: juodos ir baltos spalvos kontrastas, paprastos geometrinès formos, glaudus konstrukcijų ir architektūrinès estetikos ryšys.

Objektai. Naujosios krypties modernioji architektūra septintajame dešimtmetyje Lietuvoje, visų pirma pasireiške interjeruose. Čia išryškejjo stilistiniai moderniosios architektūros bruožai: saikingas dekoras, funkcijos ir meninès formos ryšys. Žymesni interjerai: „Neringos“ viešbutis ir kavinè Vilniuje (A. ir V. Nasvyčiai 1959-1960 m.), „Tauro“ restoranas Vilniuje (V. Batisa 1961 m.), „Tulpès“ restoranas Kaune (V. Dičius ir A. Mikènas 1961 m.), Centrinis paštas Vilniuje (A. ir V. Nasvyčiai 1969 m.) ir kt. (Mačiulis 2002).

A. Mačiulio teigimu, Sovietu sajungos respublikose pokyčiai vyko laipsniškai, tačiau Lietuvoje viskas vyko sparčiau. Svetimos meninès idejjos, propaguojančios socrealistinius projektavimo principus, nebuvo labai populiarios tuometinių Lietuvos architektų tarpe, todèl buvo prisimintos tarpukario racionaliosios architektūros tradicijos (Mačiulis 1993). Tam, kad galima būtų peržengti istoristinę architektūrą, reikèjo atsigręžti i praeiti, į tarpukario Lietuvos architektūros stilistiką, kurioje jau tuo metu buvo matyti modernistinių idejjų. V. Petrulis teigia, jog „buvusioje Sovietų sajungoje ir jos įtakos zonoje šis procesas gali būti ịvardijamas kaip remodernizacija, sugrịzimas prie ikistalininejje epochoje besiformuojančių architektūros idealų. Lietuviškame kontekste šị procesą taip pat iš dalies galime traktuoti kaip tarpukario moderniosios architektūros mokyklos tęstinumą“" (Petrulis 2012b). Ne viename šeštojo dešimtmečio antrosios pusès, septintojo dešimtmečio pradžios projekte matomi tam tikri tarpukario modernizmo architektūriniai elementai (kompoziciškai išryškintas iejjimo stogelis, apvalaus lango motyvas ir kt.) (Petrulis 2006).

Vienas ankstyvesnių tokios meninès raiškos pastatų Lietuvos architektūroje buvo Klaipèdos kultūros rūmai (dab. Muzikinis teatras), projektuoti Algimanto Mikèno 1959 m. Pastato funkcinis zonavimas, išsidèstymas sklype, horizontalių ir vertikalių korpusų žaismas nurodo moderniosios architektūros įtaką, tačiau tiek proporcijos, tiek dekoratyvi ritmika, tiek raudonos spalvos akcentai rodo glaudžias sąsajas ne tik su tarpukario Kauno architektūra, tačiau ir pokario realizmo manieringumu. Kitas svarbus šio laikotarpio objektas - Miestų statybos projektavimo instituto pastatas Vilniuje (2 pav.), projektuotas Eduardo Chlomausko (1961 m.). Nors šiame komplekse vyrauja simetriška planinè ir tūrinė kompozicija, sumodernintų istorinių detalių užuominos, aiškių formų 
lakoniški pastato tūriai nurodo funkcionalios tarptautinio stiliaus architektūros siekius.

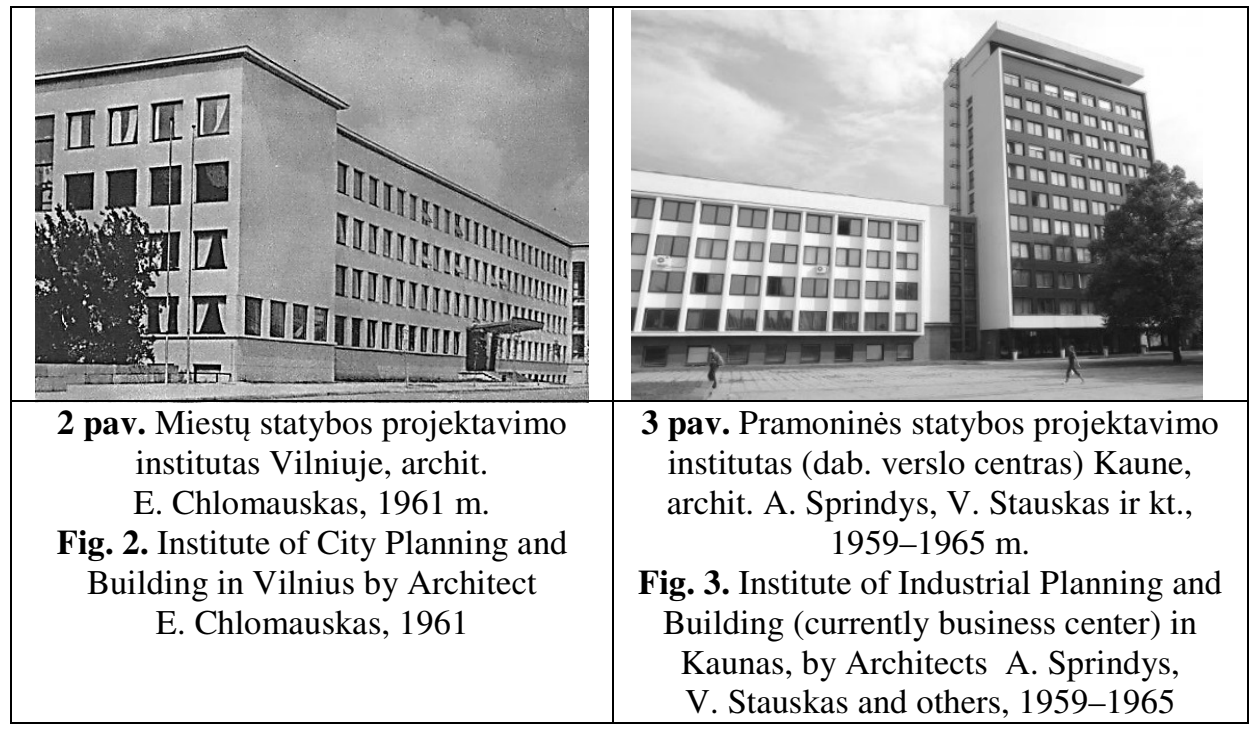

Panašaus pobūdžio objektas, tačiau jau pasižymintis ryškesne tarptautinio stiliaus ittaka - Pramoninès statybos projektavimo instituto rūmai (3 pav.), (dab. verslo centras) Kaune (1959-1965 m. archit. A. Sprindys, V. Stauskas ir kt.). Šis trijų dalių kompleksas užbaigè tuometinès vienybès aikštès užstatymą. Vertikalioji komplekso dalis sukūrè kompozicinę atsvarą Karo muziejaus bokštui, žemesnieji korpusai įsiliejo į esamą užstatymą, pabrežè aikštès kontūrą. Nors komplekso architektūros meninèje raiškoje dominuoja tarptautinio stiliaus elementai - aiškiai artikuliuoti tūriai, tamsių stiklo ir baltų tinko plokštumu žaismas fasaduose, galima izžvelgti ir tarpukario Kauno racionaliosios architektūros požymių. Dekoratyvus žemesniojo korpuso langų apvadų ritmas turi sąsajų su greta esančiu Karo muziejumi, Prisikèlimo bažnyčia. Tarpukario moderniosios architektūros meninè raiška, persipynusi su tarptautinio stiliaus tūriniais ir erdviniais projektavimo principais atsispindejo ir kituose objektuose, pavyzdžiui Lietuvos Aukščiausiojo Teismo rūmų pastate (archit. Vladimiras Oleiničenka 1965 m.), kartotiniame restorano projekte, pastatytame Trakuose, vèliau pritaikytame ir kitiems miestams (archit. B. Kazlauskas 1961 m.).

Vienas pagrindinių tarptautinio stiliaus bruožų - konstrukcinès pastato sąrangos dominavimas architektūrinejje pastato raiškoje, atsiskleidè ekspresyvia konstrukcijų estetika pasižyminčiame kartotiniame universalinès parduotuvès projekte (1966-1969 m. archit. A. Patalauskas), kurio fragmentas pateiktas 4 paveiksle. Funkcionaliai suprojektuotą pastatą sudaro du pagrindiniai tūriai, kurių viršutinis paremtas ekspresyviomis, V formos atramomis. Pastarosios 
dekoratyvaus stogelio pavidalu atkartojamos išilgai viso pastato. Toks principas, kuomet pastato eksterjere konstrukcijos igyja dominuojančios architektūrinès raiškos bruožu, pastebimas daugelyje tarptautinio stiliaus pastatų, pavyzdžiui $1932 \mathrm{~m}$. architekto O. Williams suprojektuotoje gamykloje Beeston mieste, D. Britanijoje (5 pav.).

\begin{tabular}{|c|c|}
\hline $\begin{array}{c}4 \text { pav. Tipinio universalinès } \\
\text { parduotuvès pastato fragmentas, archit. } \\
\text { A. Patalauskas, 1966-1969 m. } \\
\text { Fig. 4. Fragment of multiple store } \\
\text { building by Architect A. Patalauskas, } \\
\text { 1966-1969 }\end{array}$ & $\begin{array}{c}5 \text { pav. Gamyklos pastatas Beeston mieste, } \\
\text { D. Britanijoje, archit. } \\
\text { O. Williams, } 1932 \mathrm{~m} \text {. } \\
\text { Fig. 5. Factory building in Beeston, } \\
\text { Great Britain by Architect } \\
\text { O. Williams, } 1932\end{array}$ \\
\hline & \\
\hline $\begin{array}{c}\text { 6 pav. Kauno technologijos } \\
\text { universiteto pastatas (buv. KPI), archit. } \\
\text { V. Dičius, 1964-1970 m. } \\
\text { Fig. 6. Kaunas University of } \\
\text { technology (former KPI) by Architect } \\
\text { V. Dičius, 1964-1970 }\end{array}$ & $\begin{array}{l}7 \text { pav. Baldu parduotuvė Kaune, archit. } \\
\text { V. Dičius, 1963-1969 m. Maketas. } \\
\text { Fig. 7. Furniture store in Kaunas by } \\
\text { Architect V. Dičius, 1963-1969. } \\
\text { Scale model. }\end{array}$ \\
\hline
\end{tabular}

Chrestomatine tarptautinio stiliaus estetika pasižymi architekto Vytauto Dičiaus darbai. Kauno technologijos universiteto (buv. KPI) studentu miestelio pastatų (6 pav.) meninè raiška atitinka visus tarptautinio stiliaus bruožus. Laisvas planavimas matyti ne tik pastatų funkcinejje sandaroje, bet ir visame studentų miestelio užstatyme. Paprastos geometrinès formos, baltos tinko ir tamsios stiklo spalvos kontrastai, pasikartojantis stiklo ruožų ritmas, sustabdomas didesnemis stiklo plokštumomis primena ankstyvają A. Alto, G. Ain, J. A. Brickmann ir net W. Gropius kūrybą . Brandus tarptautinis stilius atsiskleidžia ir daugelio kitų to 
meto pastatų architektūrinèje raiškoje, tai kavinè - restoranas „Trys Mergelès“ Kaune (archit. V. ir A. Jakučiūnai 1965-1967 m.), prekybos ir kultūros centras „Girstutis“ Kaune (archit. V. Dičius, A. Lèckas 1966-1975 m.), sanatorijos „Pušynas“ ir „Dainava“ Druskininkuose (archit. N. Kėvišas 1965-1967 m.), ligoninių kompleksai Antakalnyje, Vilniuje (archit. E. Chlomauskas, Z. Liandzbergis 1960-1966 m.), sanatorijos Druskininkuose „Lietuva“ (archit. V. Balčiūnas ir kt. 1973 m.), „Vilnius“ (archit. R. Šilinskas 1975 m.), „Nemunas“ (archit. E. Tamoševičius 1966 m.), universalinèje parduotuvèje Vilniuje (archit. Z. Liandzbergis, V. Vielius ir kt. 1962-1973 m.) ir kt.

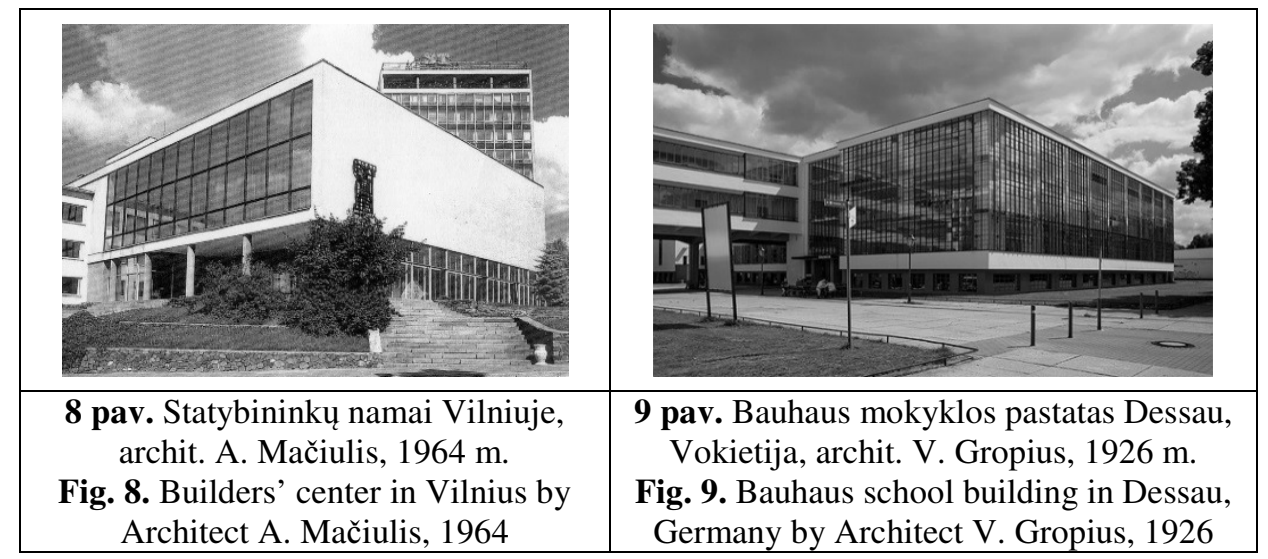

Monumentalios, aklinų sienų ir ištisinių stiklo plokštumų sankirtų architektūrinès raiškos požymių, būdingų Bauhaus architektūrai (9 pav.), galima pastebèti Algimanto Mačiulio projektuotame, Statybininkų namų Vilniuje (1964 m.), horizontaliajame korpuse (8 pav.). Panaši meninè raiška pastebima ir V. Dičiaus projektuotoje baldų parduotuveje Kaune (1963-1969 m., rekonstrukcija 2005 m., archit. G. Kazakauskas) (7 pav.), taip pat kartotiniame universalinès parduotuvès projekte (archit. A. Patalauskas 1963 m.). Pasak A. Mačiulio, tokio ploto stiklo plokštumų naudojimą architektūriniuose sprendimuose stabdè techninès galimybès, unifikuotu sprendimų nebuvimas, gamybos procesai turejjo būti organizuojami autonomiškai, techninius sprendimus, montavimo brěžinius kuriant kiekvienam objektui atskirai.

Šiek tiek funkcionalesnę, tuo pačiu ir grubesnę tarptautinio stiliaus raišką, būdingą Mies Van der Rohe ir Philip Johnson (11 pav.), ar Eero Saarinen (13 pav.) projektuotiems verslo centrams ar administraciniams pastatams JAV, galima ¡ž̌velgti dabartinès Ūkio ministerijos pastate, Vilniuje (archit. E. N. Bučiūtè 1973 m.) (10 pav.), „Miestprojekto“ pastate Kaune (archit. A. Sprindys 1975 m.) (11 pav.), o taip pat ir "Lietuvos pašto" galiniuose fasaduose (archit. V. ir A. Nasvyčiai 1969 m.). Šiu pastatų fasaduose dominuojančios aliuminio rèmų konstrukcijos, nepertraukiamo stiklo plokštumos kuria prabangos įspūdį. 
Šeštojo - septintojo dešimtmečio JAV, kuomet tokia architektūros objektų meninè raiška buvo itin populiari, ji tarnavo korporacijų ịvaizdžiui, demonstravo solidumą, bet tuo pačiu ir skaidrumą. Lietuvoje tai buvo daugiau formos, o ne turinio klausimas.

\begin{tabular}{|c|c|}
\hline & \\
10 pav. Ukio ministerijos pastatas & 11 pav. Seagram administracinis \\
pastatas Niujorke, JAV, archit.
\end{tabular}

Bendrame šio laikotarpio architektūros objektų kontekste išsiskiria keli objektai, kurie, dẻl specifinès paskirties, dèl išskirtinių inžinerinių sprendimų igyja nagrinèjamai architektūros krypčiai nebūdingą, ekspresyvesnę architektūrinę raišką, tačiau atitinka visus tarptautinio stiliaus architektūros bruožus. Tai Vingio parko dainų estrada Vilniuje (archit. A. Kotli, H. Sepmann 1960 m.) (14 pav.) ir ledo arena Elektrénuose (konstr. A. Kanapeckas 1960 m.) (15 pav.). Bioninių formų, sudètingo konstrukcinio sprendimo Vingio parko dainų 
estrada pastatyta pagal Estijos architektu projektą. Baltos spalvos stogo konstrukciją laikanti arka dominuoja pastato tektonikoje, pabrèžia funkcinę estrados estetiką. Ekspresyvi planinè struktūra, elementarus ir atpažįstamas stogo tūris, pabrèžtinai intensyvus antžeminès dalies konstrukcijų ritmas, nuožulniai kylančios žiūrovų tribūnų eilès skatina ieškoti paralelių su gamtinèmis formomis. Elektrėnų ledo arena projektuota kiek kitokiais principais. Uždarą planinę struktūrą apgaubia kiauto formos kupolas, kurio banguotą formą visu pastato perimetru atkartoja laužytų stogo plokštumų motyvas. Tarp konstrukcinių elementų išdèstyti stiklo intarpai sušvelnina uždarumo įspūdi, pastato fasaduose pradeda dominuoti konstrukciniai motyvai pabrěžiantys tarptautinio stiliaus charakteri.

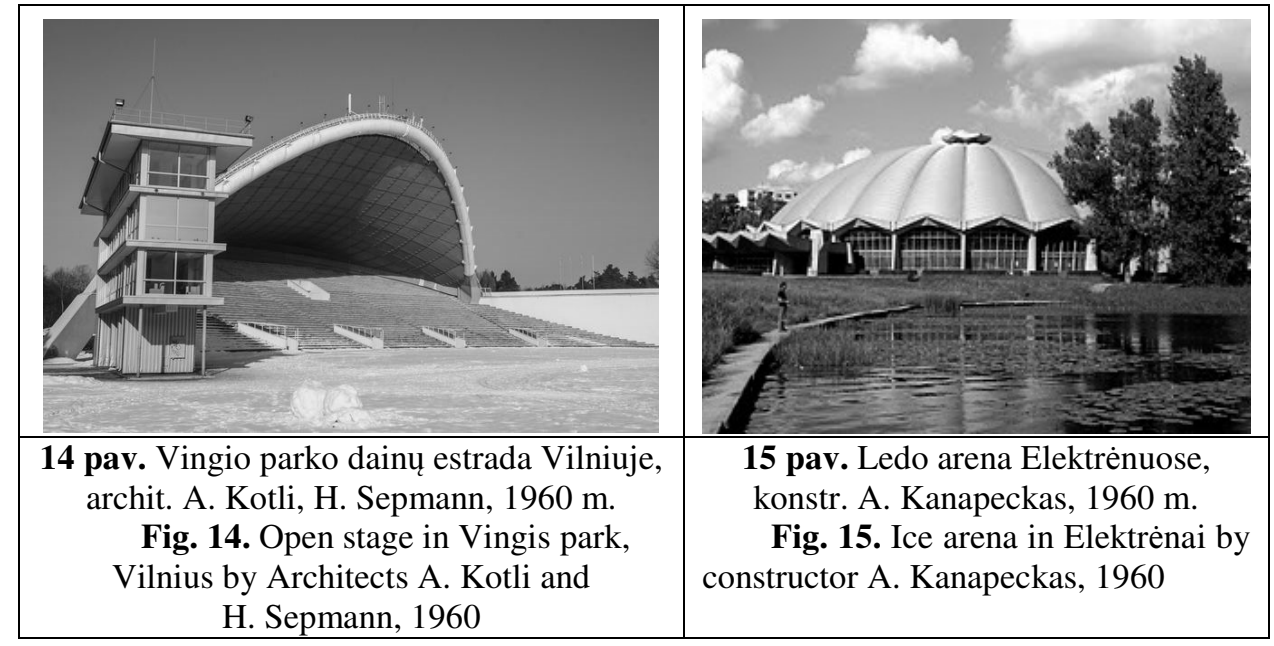

1978 m. pastatytas „Turisto“ viešbutis Vilniuje (archit. J. Šeibokas) atspindèjo naują funkcionaliosios architektūros etapą, tarptautinį stilių vẻlyvojo modernizmo įtakoje. Tuo metu, šiam prestižiniam objektui buvo skirtas ypatingas dèmesys. Tūriškai ir konstrukciškai vis dar jaučiama tarptautinès architektūros stiliaus įtaka. Septynių aukštų viešbučio karkasas - iš surenkamų konstrukcijų, lauko sienos iš gelžbetonio plokščių. Pagrindinis masyvus pastato tūris pakabintas virš žemès paviršiaus, isstiklinus pirmąji aukštą. Reljefiniai gelžbetoniniai fasado elementai pabrèžè langų ritmą, tačiau tuo pačiu suteikè pastatui dekoratyvumo, nebūdingo ankstyvujjų tarptautinio stiliaus objektų meninei raiškai. Panaši architektūrinè raiška pastebima buv. buities tarnybų rūmų komplekse Vilniuje (archit. A. Nasvytis ir kt. 1975 m.), viešbutyje „Lietuva“ Vilniuje (archit. A. ir V. Nasvyčiai 1967-1984 m.) (16 pav.), prekybos centre „Merkurijus“ Kaune (archit. A. Sprindys 1969-1983 m., neišlikęs) (17 pav.). 


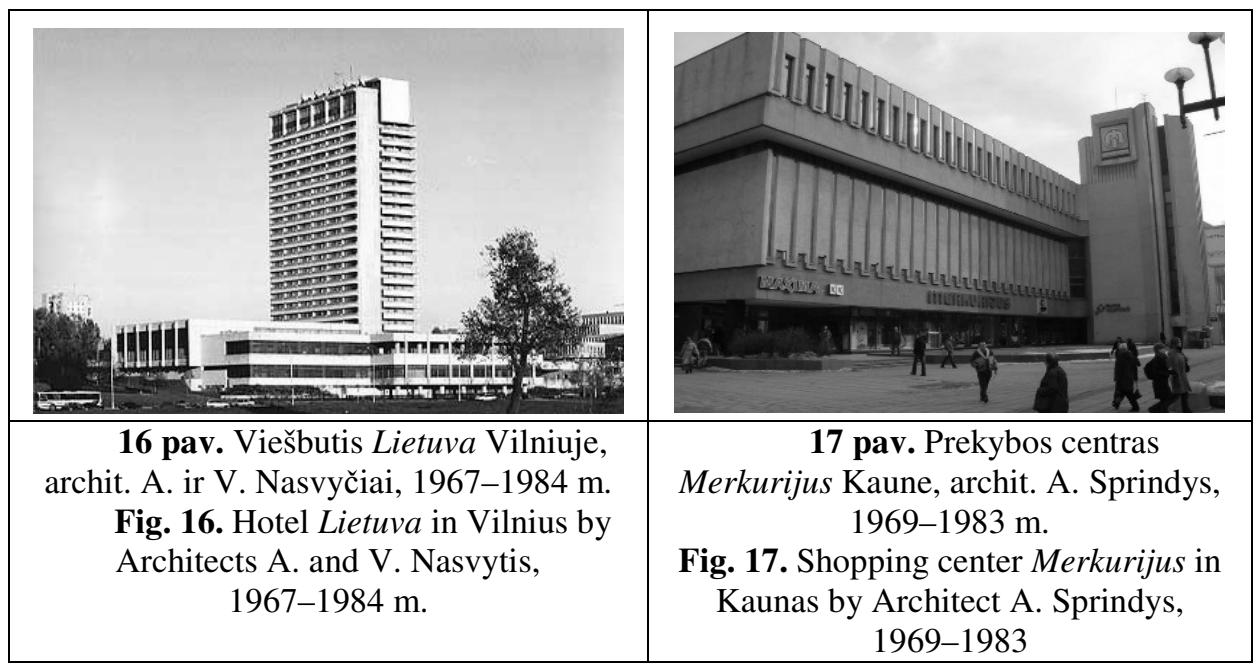

\subsection{Kritinis regionalizmas ir tautiškumo aspektas moderniojoje Lietuvos architektūroje}

Kritinio regionalizmo sąvoka ir ištakos, pagrindiniai meninės raiškos bruožai. Kritinį regionalizmą architektūroje visų pirma reikètų vertinti kaip prieštarą tarptautinio stiliaus meninès raiškos anonimiškumui, savitumo neigimui. Šios architektūros krypties tikslas - moderni architektūra, tačiau paremta vietinèmis tradicijomis, kultūriniu kontekstu. Būtina atkreipti dèmesị, kad kritinis regionalizmas skiriasi nuo tautinių motyvų naudojimo architektūroje, šiai krypčiai būdinga sąsajų tarp tradicijų ir moderniosios architektūros paieška (Foster 1983). Vèlesniuose etapuose kritinis regionalizmas neigia ir postmodernistinę ornamentiką ir puošybą, kaip nemodernu būdą perteikti tradiciškumą. H. F. Mallgrave ir D. Goodmann teigia, jog siekis atrasti regionalumo charakteri moderniojoje architektūroje yra toks pat senas, kaip ir pati modernioji architektūra (Mallgrave 2011). Šiuos tikslus galima sieti su architektūros, kaip meno šakos tarpdiscipiniškumu, atvirumu mokslo idejjų įtakoms, socialiniams ir kultūriniams kontekstams, vadinamai laikmečio dvasiai. Tai, jog savitumo klausimas nesvetimas ir globaliam tarptautiniam stiliui, dar 1925 metais pastebi Walter Gropius knygoje „International Architecture“ pažymédamas, jog architektai nekuria laikmečio dvasios, jie jai paklūsta, ir nors kiekvieno architekto kūrinys yra jo kūrybinio potencialo atspindys, kūrybinis potencialas yra itakojamas daugybès faktorių, visų pirma kultūrinès aplinkos. Ir nesvarbu, jog pastatas kuriamas tam tikrais tarptautiniais principais, būdingais tam laikmečiui, architektas visuomet įneš individualumo ir nacionalinio charakterio. W. Gropius 
apibendrina - architektūra visuomet nacionalinè, visuomet individuali ir tarptautine ją padaro tik bendrasis, humaniškasis aspektas (Gropius 2008).

Kritinio regionalizmo idejos, tiesa iki tol neįvardintos, populiarejo JAV, kur pasireiškè daugiau kaip priešprieša iš Europos ateinančiam globaliam tarptautiniam stiliui. Vienas iš bandymų ieškoti nacionalinio charakterio architektūroje, buvo James Ford ir Katherine Morrow Ford knyga ,,The Modern House in America“ (1940 m.), kurioje analizuojami gyvenamujų namų architektūros meninès raiškos skirtumai skirtinguose JAV regionuose, nurodant esminius skirtumus. Vèlesneje publikacijoje „Modern is Regional“ (1941 m.), K. M. Ford išdèsto pagrindinius moderniosios architektūros meninès raiškos savitumą ịtakojančius veiksnius, tai:

- klimatas;

- medžiagos;

- $\quad$ socialiniai regiono ipatumai.

Klimatinès zonos įtakoja patalpų planavimo principus, jų orientaciją pasaulio šalių atžvilgiu, krituliai daro itaką pastato formai. Vietiniams meistrams prieinamos medžiagos įtakoja konstruktyvinius sprendimus, architektūrinę raišką. Socialinis aspektas nurodo žmonių gyvenimo papročius ir ịpročius (Ford 2008).

Pirmieji bandymai ivardinti regionalumo apraiškas moderniojoje architektūroje pastebimi XX a. penktojo - šeštojo dešimtmečio sandūroje. 1947-aisiais Lewis Mumford moderniąą Kalifornijos (JAV) architektūrą pavadina Pakrantès regiono stiliumi, kuris, autoriaus teigimu, yra ,gerokai universalesnis nei taip vadinamas tarptautinis stilius, nes jame matoma Rytu Azijos ir Vakarietiška įtakos“ (Mumford 2008), iškart po to J. M. Richards naujają Skandinavų architektūrą pavadina Naujuoju Empirizmu (angl. - New Empiricism) (Richards 2008), Sigfried Giedion teigia, jog tai yra Naujasis regionalusis požiūris ì moderniają architektūrą (angl. - New Regional Approach) (Giedion 2008), o Harwell Hamilton Harris teigia, jog regionalizmų yra daug, o jų pagrindiniai skirtumai pasireiškia idejose, kurios juos įtakoja (Harris 2008).

Kritinio regionalizmo terminą pirmieji panaudojo Alexander Tzionis ir Liane Lefaivre, tyrinėdami šeštojo dešimtmečio Graikijos moderniają architektūrą, kurioje matėsi vietos architektų bandymai išsivaduoti iš griežtų tarptautinio stiliaus rèmų (Tzionis 1981). Vèlesniuose tyrimuose A. Tzionis ir L. Lefaivre apima platesni geografinị objektų spektrą, ir kritinio regionalizmo bruožų aptinka kitose valstybėse, kuriose ši kryptis pasireiškia skirtingai, tačiau remiantis tais pačiais kūrybos principais. Šiam tyrimui svarbūs pagrindiniai kritinio regionalizmo bruožai, suformuoti minètame tyrime (Tzionis 1992):

1. Charakterizuojami ir stilizuojami regionui būdingi architektūriniai elementai ar formos, ir pritaikomi naujajame, moderniais principais suprojektuotame pastate. Pavyzdžiui, gyvenamujų namų kvartale, Venecijoje, Italijoje (1980-1985 m.), architektas G. De Carlo, panaudojo charakteringiausius 
Italijos architektūros bruožus - fragmentuotus ịvairių formų tūrius, langelių formas, spalvinius sprendimus ir pasiūlè kontekstualų naujos architektūros sprendimą (18 pav.).

2. Naujai projektuojamame pastate gali atsispindèti konkrečios vietovès charakteris, taip pat ir aplinkinio užstatymo bruožai. Pavyzdžiui, teismo rūmų pastate Sevilijoje, Ispanijoje (1982-1990 m.) architektai R. Amado ir L. Domenech panaudojo greta esančių gynybinès sienos ir bokšto motyvus. Visas Teismo rūmų kompleksas sukuria uždarumo ir solidumo ịspūdị, tačiau viršuje esantis pravažiavimas ir terasos veikia kaip viešosios erdvès (19, 20 pav.).

3. Kritinis regionalizmas gali būti naudojamas siekiant defamiliarizuoti vietovę. Tokiu atveju tam tikri vietovei būdingi elementai akentuojami, bet naudojant netikètą, nebūdingą architektūrinę raišką. Pavyzdžiui, daugiabučio gyvenamojo namo projekte Sevilijoje, Ispanijoje (archit. A. Cruz ir A. Ortiz 1974-1976 m.) nei viena detalè nèra tradicinè ar būdinga aplinkiniams pastatams. Vidinis kiemas, kuris turètų būti stačiakampio formos šiame komplekse neregularus, plastiškas, ir vis dèlto, kontekstualus. Ne forma, o turiniu (21 pav.). Kiek kitaip defamiliarizacija akcentuojama Romènu meno muziejaus pastate Meridoje, Ispanijoje (archit. R. Moneo 1980-1986 m.). Reguliarus sienu su arkomis tinklas mechaniškai uždedamas ant istorinių pamatų, tačiau perdangos atkartoja istorini patalpų išdèstymą. Vidinès erdvės atrodo netikètai, kadangi pastate nèra jokio sienų ir perdangų tarpusavio ryšio (22, 23 pav.).

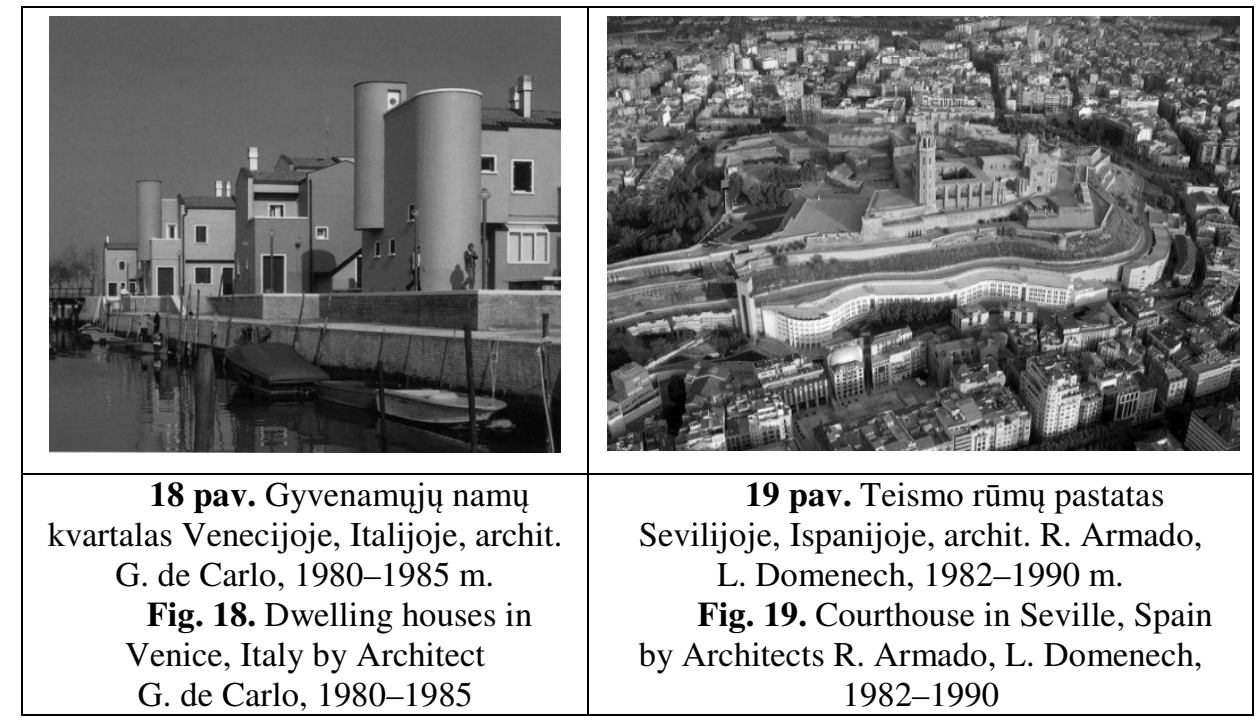




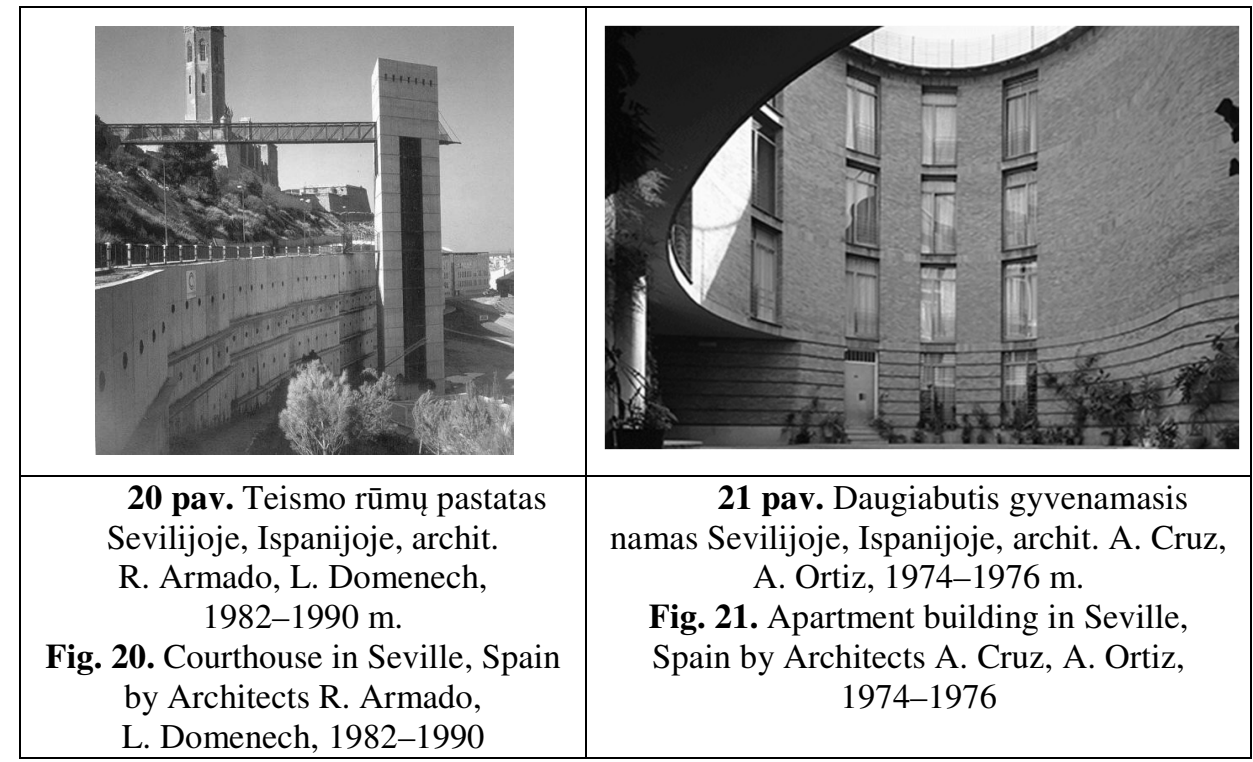

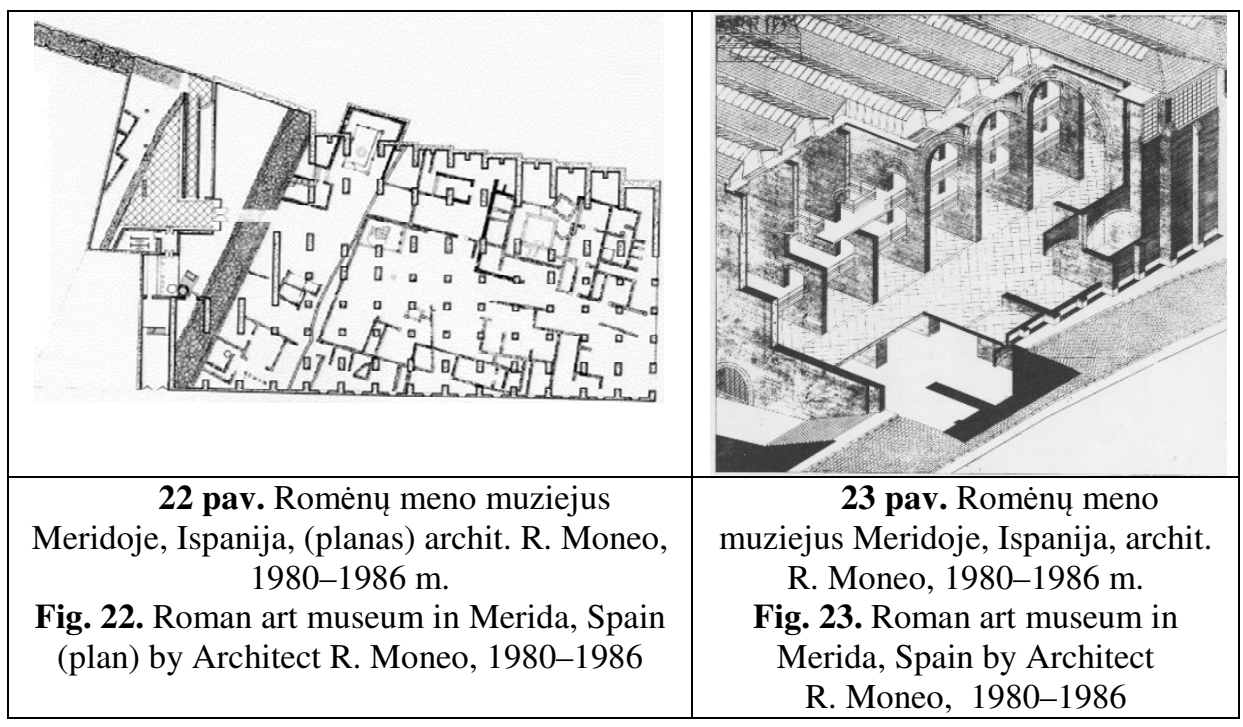

Kritinio regionalizmo sąvoką papildè Kenneth Frampton, šiai architektūros krypčiai apibūdinti naudodamas Vietos o ne erdvès sąvoką (čia turima omenyje tai, jog architektūros objektas yra ne erdvé, kuri gali būti kuriama bet kur, o tam tikra, konkreti vieta). Tam pritare architektai A. van Eyck, L. Kahn, K. C. Bloomer, Ch. Moore, kurių kūryboje vietos konceptas buvo aiškiai artikuliuotas. K. Frampton išdèstè pagrindinius Kritinio regionalizmo bruožus straipsnyje „Towards a Critical Regionalism: Six Points for the Architecture of 
Resistance“ (Frampton 1983). Jeigu A. Tzionis ir L. Lefaivre kritinį regionalizmą traktavo kaip pasipriešinimą moderniosios architektūros tarptautiškumui ir beveidiškumui, tai K. Frampton teigimu, kritinis regionalizmas yra priešprieša visa apimančiai postmodernizmo pop kultūrai, nes architektūroje vertina: a) vietą ir formą; b) topografiją, kontekstą, klimatą ir šviesą; c) pojūčius ir tektoniką. Pasak K. Frampton, termino kritinis regionalizmas nèreikètu painioti su terminu vietinis arba liaudiškas ${ }^{3}$, kuris apima klimatą, kultūrą, meistrystę ir netgi mitologiją, o kritinio regionalizmo terminas skirtas nustatyti globalių moderniosios ir postmoderniosios architektūros stilių savitumų priežastingumą.

Kritinio regionalizmo pavyzdžiu pagal K. Frampton, galima laikyti Bagsvaerdo bažnyčią greta Kopenhagos, Danijoje (archit J. Utzon 1976 m.), pasižyminčią regionalių formų interpretavimu ir simbolistiniais interjero erdvių sprendimais (24, 25 pav.), daugiabuti namą Barselonoje, Ispanijoje (archit. J. A. Coderch $1951 \mathrm{~m}$.), stilizavusị ir savaip interpretavusị vietinei architektūrai būdingas langinių plokštumas ir jų dominavimą fasadų architektūrinèje raiškoje (26 pav.), vietinès architektūros objektams būdingu medžiagiškumu ir charakteriu pasižyminčius individualius gyvenamuosius namus Povoa de Varzim, Portugalijoje, (archit. A. Siza 1973-1977 m.) ir Udineje, Italijoje (archit. G. Valle 1954-1956 m.), ir kt. Dèl modernistinių formų adaptavimo vietinèms tradicijoms, unikalaus medžiagiškumo ir minimalistinių tendencijų sintezès, sąsajų su simbolizmu, kritiniam regionalizmui galima priskirti ir Tadao Ando darbus (Furuyama 2006) (27 pav.).

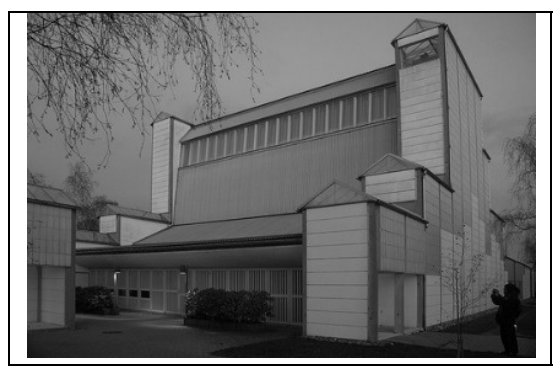

24 pav. Bagsvaerd bažnyčia

Kopenhagoje, Danijoje, archit.

J. Utzon, $1976 \mathrm{~m}$.

Fig. 24. Bagsvaerd church in Copenhagen, Denmark by Architect J. Utzon, 1976

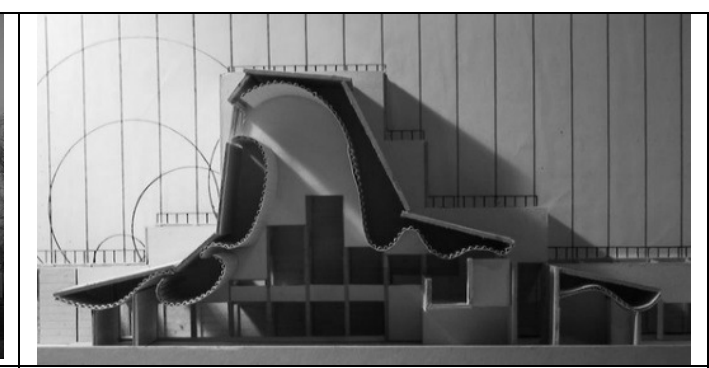

25 pav. Bagsvaerd bažnyčia

Kopenhagoje, Danijoje (maketo pjūvis), archit. J. Utzon, $1976 \mathrm{~m}$.

Fig. 25. Bagsvaerd church in Copenhagen,

Denmark (cross section of a model) by Architect J. Utzon, 1976

Kritinis regionalizmas niekada netapo savarankiška, lengvai identifikuojama architektūros kryptimi, turinčia lengvai apibrèžiamus meninès raiškos bruožus. Tai prieštarautų pačiai šios krypties idèjai, kuri akcentuoja ne erdvę, o vietą, ne

${ }^{3}$ Vernacular (angl.) 
bendrai suvokiamus architektūrinès formos kūrimo principus, o individualų kūrèjo požiūri i i konkrečią situaciją. Vis dèlto, vadovaujantis bendrais kritinio regionalizmo bruožais, nagrinèjant bendrą Lietuvos moderniosios architektūros kontekstą, yra įmanoma nustatyti tam tikrus kritinio regionalizmo meninès išraiškos bendrumus Lietuvos architektūroje.

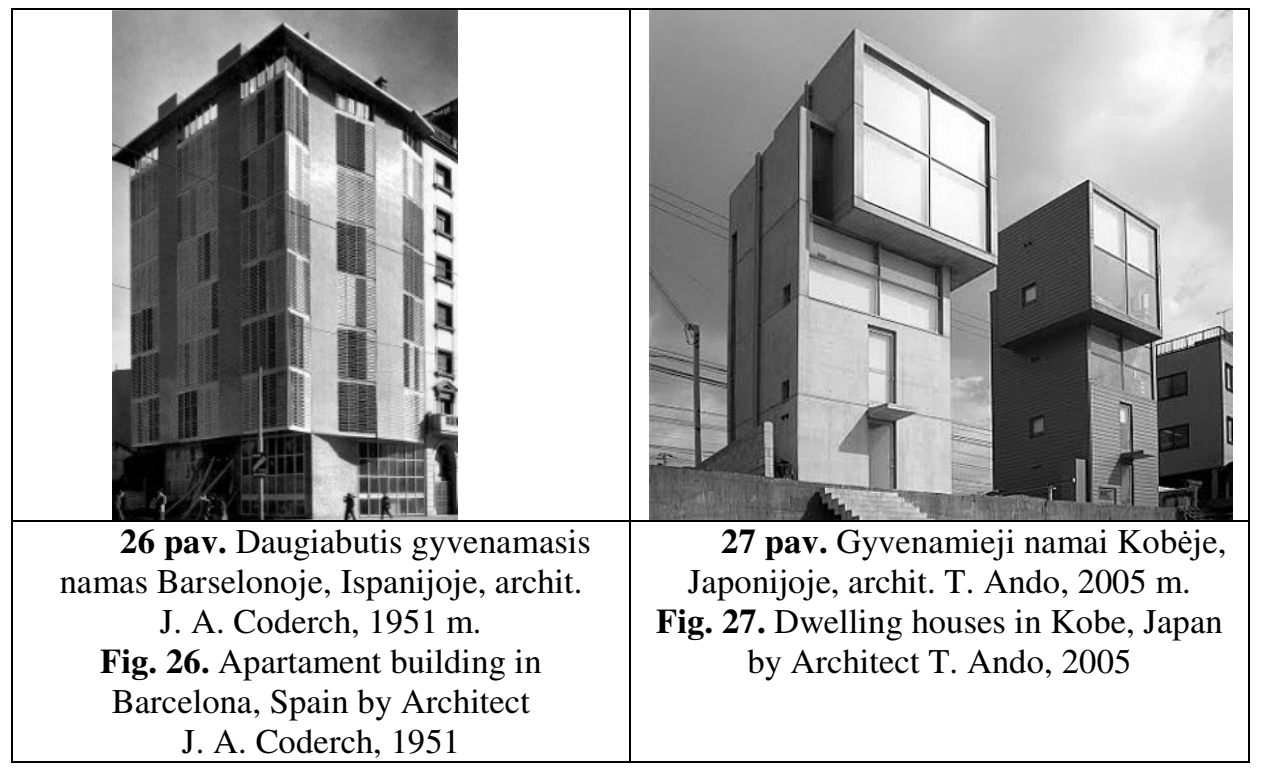

Kritinio regionalizmo meninès raiškos tendencijos Lietuvos architektūroje. Pirmieji kritinio regionalizmo bruožai Lietuvos architektūroje pastebimi architektų bandymuose panaudoti vietines medžiagas, prie jų derinant grynas tarptautinio stiliaus formas. Tai apsiribojo plytų mūro ar skaldyto akmens panaudojimu pirmojo aukšto apdailai, paryškinančiai funkcionalią tūrinę kompoziciją. Kaip pavyzdi galima paminèti kartotini kino teatro projektą Druskininkuose (archit. V. Juršys 1965 m.) (28 pav.), kuriame naudojamas ne tik plytų mūras, tačiau ir ịvairesnè tinko apdaila (kadangi projektas tipinis, kiekvieną kartą šiek tiek skyrèsi ir architektūrinè raiška). Individualus gyvenamasis namas su dirbtuvèmis antakalnyje (archit. E. Bergaitè-Burneikienè 1959 m.) (29 pav.) pasižymi tarptautinio stiliaus architektūrine raiška, matoma ir Le Corbusier vilų įtaka, tačiau skaldyto akmens cokolis, pereinantis į reljefą, šlaitinis stogas suteikia pastatui kontekstualumo, prisitaiko prie gamtinès situacijos. Išskirtine tarptautinio stiliaus funkcine - erdvine raiška ir formomis dominuoja restoranas „Vasara“ Palangoje (archit. A. Eigirdas 1964-1967 m.). Lakoniškų geometrinių formų tūriai apjungti banguojančia pirmo aukšto linija. Ekspresyvumu pasižymi cilindro formos dviaukštè, stiklinè restorano dalis, kuri laikèsi ant piltuvo formos kolonos, ant kurios išdèstomi taškiniai apšvietimo elementai. Regionalumo šiam pastatui 
suteikia gausus, liaudiškais motyvais paremtas dekoras, naudojamas tiek fasaduose, tiek interjeruose, skulptūriški lipdiniai, ornamentika.

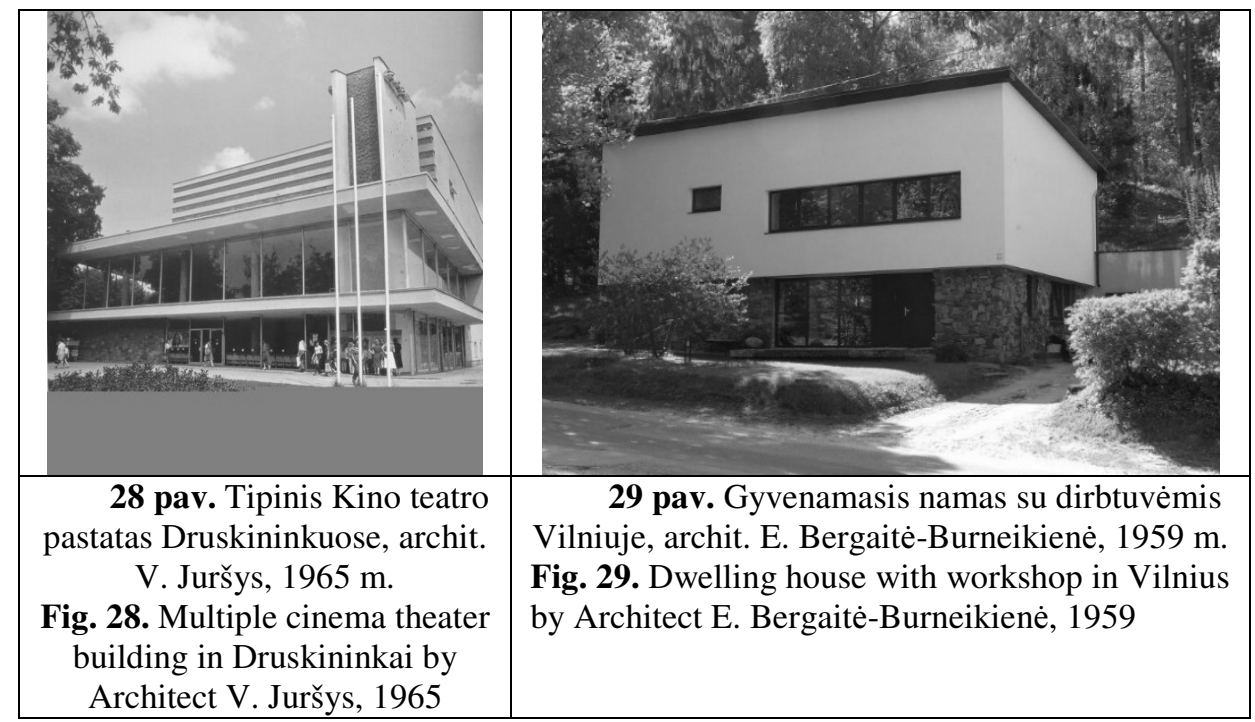

Po kelių pasisekusių bandymų, Lietuvos architektai pradejo eksperimentuoti ne tik su medžiagomis, bet ir su tarptautiniam stiliui būdingomis formomis, tūriais, planiniais spredimais. Vienas iš tokių objektų - Vytauto Edmundo Čekanausko suprojektuoti Kompozitorių namai Vilniuje (1960-1966 m.). Pagrindinio korpuso architektūrinėje raiškoje, medžiagų panaudojime ir pastato proporcijose jaučiama didelè Suomijos architekto A. Aalto įtaka (Gerliakas 1993). Kompleksas išsiskiria ypatingu kontekstualumu, pagarba gamtinei situacijai, pagrindinio pastato tūris medžiagiškai atskirtas, laužtas viršutinis perklausų salès tūris atrodo lengvai uždètas ant grubaus plytų mūro. Šoninų langų plokštumų vertikalumas pabrèžtas medžio ažūru (panašūs sprendimai panaudoti ir A. Aalto studijos pastate Helsinkyje, Suomijoje (30 pav.), Rotušès pastate Saynatsalo mieste, Suomijoje, vasaros rezidencijoje Muuratsalo gyvenvieteje Suomijoje, ir kituose objektuose (Lahti 2004), o V. E. Čekanauskas ši motyvą plètojo ir Šiuolaikinio meno centro gatvès ir kiemo fasaduose), pagrindinio fasado stiklo plokštuma sudalinta De Stijl estetiką primenančiu ritmu. Išorèje dominuojanti skirtingų medžiagų raiška atsispindi ir interjeruose. Panašiu medžiagų panaudojimu vidinėse erdvėse pasižymi ir Vilniaus centrinis paštas (archit. A. ir V. Nasvyčiai 1969 m.), bei Nacionalinis dramos teatras Vilniuje (archit. A. ir V. Nasvyčiai 1981 m.). 


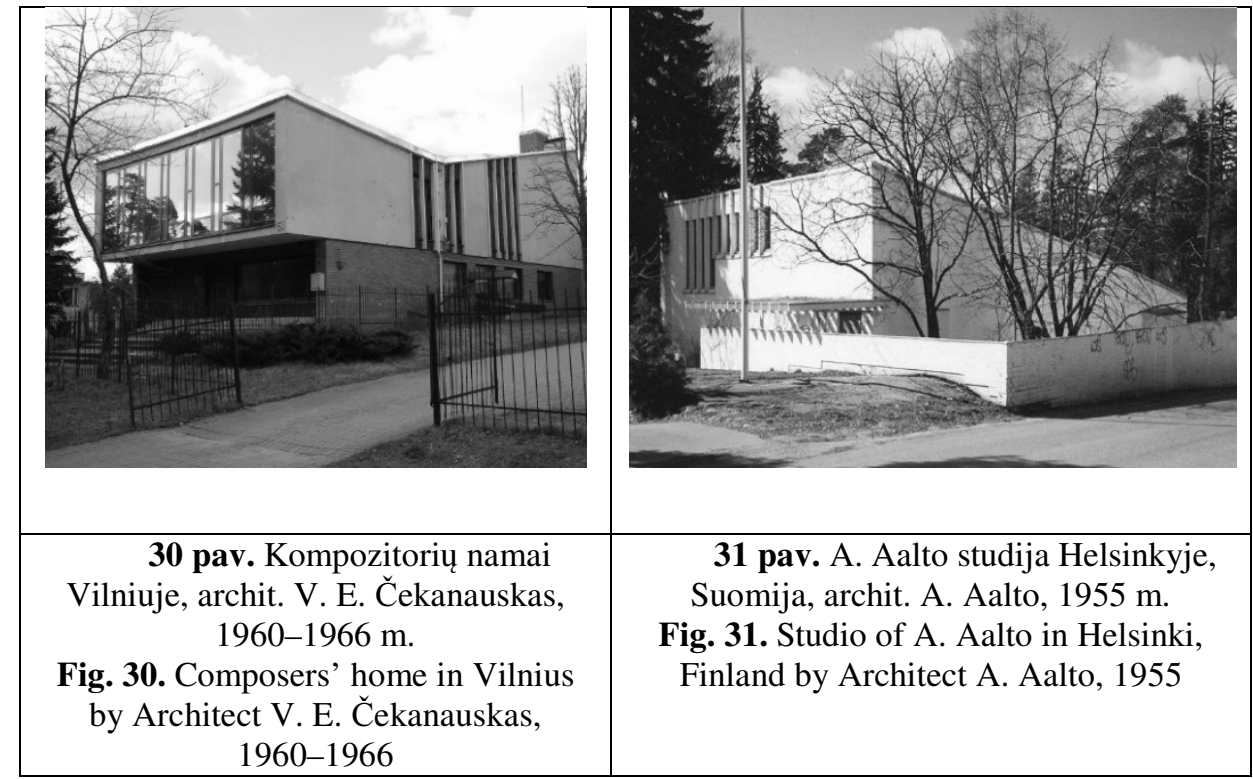

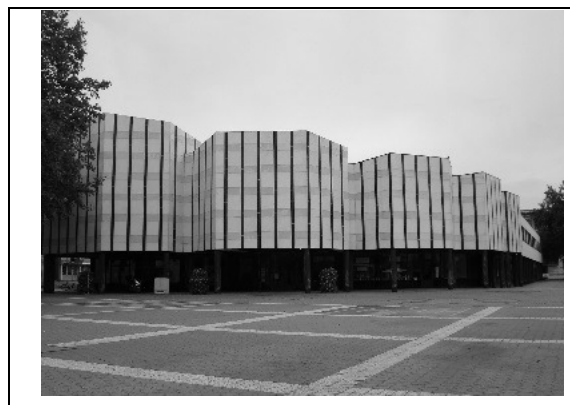

32 pav. Kultūros centras

Volfsburge, Vokietijoje, archit.

A. Aalto, 1959-1962 m.

Fig. 32. Cultural centre in Wolfsburg,

Germany by Architect A. Aalto, 1959-1962

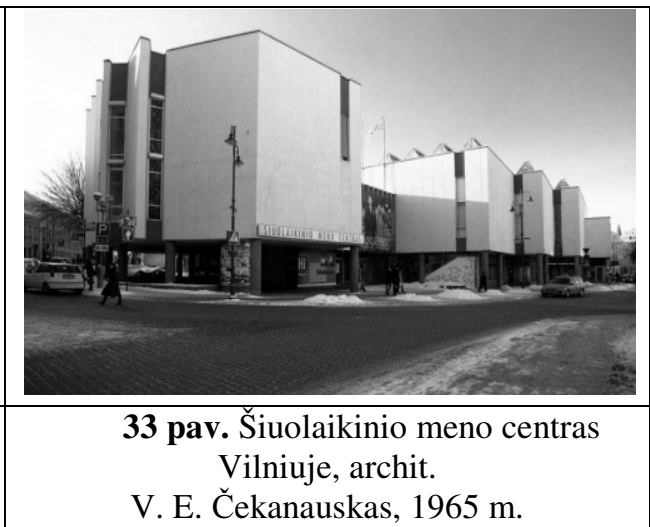

Fig. 33. Contemporary art centre in Vilnius by Architect V. E. Čekanauskas, 1965

Nuosaikių formų kompozicija, ikvèpta A. Aalto kūrybos (32 pav.) (Fleig 1975), adaptuota Vilniaus senamiesčio kontekstui, pasižymi Šiuolaikinio meno centro architektūrinè raiška (archit. V. E. Čekanauskas 1965 m.). Pagarba istoriniam užstatymui ịtakojo pastato tūrinius - planinius sprendimus dviem aspektais. Visu pirma buvo stengiamasi išsaugoti senovinius rūsius, kurie buvo atidengti tik 2003 m. (Drèmaitè, et. al 2012), taip pat siekiant neužgožti Visų Šventuju bažnyčios varpinès, žiūrint nuo Didžiosios gatvès. Masyvus pastatas skaidomas ị smulkesnius tūrius, kurie savo ruožtu dalinami langų ir tamsaus tinko 
plokštumomis, taip parodų kompleksas įsilieja ị istorinị senamiesčio užstatymą. Subalansuotu proporcijų kiemo fasade stiklo plokštumos pabrèžtinai sudalintos vertikalèmis, kurios kartojasi ir ažūrine forma (33 pav.). Kiti kontekstualumu ir nuosaikiomis architektūrinėmis formomis pasižymintys objektai: Vytauto Didžiojo universiteto rūmai Kaune (archit. B. Zabulionis 1974 m.), Vilniaus autobusų stotis (archit.V. Brédikis 1974 m.) ir kt.

Kontekstualus požiūris i aplinką atsiskleidžia ir Lazdynų mikrorajono projekte (arch. V. Brèdikis, V. E. Čekanauskas 1964-1967), kur Suomiu modernizmas taip pat aiškiai pastebimas (projekto autoriai neslepia, jog didelę itaką šio projekto sėkmei turejjo jų kelionè ị Suomiją (Nekrošius 2008), o taip pat ir Le Mirail gyvenamụjų namų rajonas Tulūzoje, Prancūzijoje (archit. G. Candillis, A. Josic, S. Woods, 1964-1974 m. (Mačiulis 2011)). Nepaisant novatoriškų urbanistinių sprendimų, architektūros objektų meniné raiška priklausė nuo esamų gyvenamujų namų modulių ir turimų raiškos priemonių, juk masine gyvenamujų namų statyba buvo vykdoma išskirtinai pagal tipinius projektus. Architektai pastatų fasadus stengèsi paįvarinti balkonais, lodžijomis ar spalviniais akcentais, tačiau kalbèti apie Lazdynų mikrorajono gyvenamujų namų architektūrinès raiškos išskirtinumą nèra prasmès, mikrorajono savitumas buvo pasiektas urbanistiniu požiūriu. Kaip teigia A. Mačiulis: „,V. E. Čekanauskui ir V. Brédikiui pavyko subtiliai panaudoti puikias gamtines sąlygas, tapybišką reljefą“" (Mačiulis 2004). Humaniškas požiūris ị gamtą, organiškumas, optimalaus mastelio paieška buvo akivaizdi priešprieša tuo metu vyravusiai „universaliai“ ir „bereikšmei“ architektūrai. V. E. Čekanausko pastangomis buvo išsaugota dalis planuotų sunaikinti žaliuju plotų, tipiniai, stambiablokiai, nepaslankūs transformacijoms gyvenamieji namai ịsiliejo ị susiklosčiusi gamtinị karkasą, o aukštuminis užstatymas pabrěžè reljefo peraukštejjimą (Nekrošius 2008). Lazdynuose akivaizdžiai pasiteisino architektų siekis išvengti stereotipinių, mikrorajonams būdingų uždarų erdvinių-tūrinių kompozicijų, buvo vengiama laikytis kokio nors susikurto piešinio matomo ir jaučiamo tik planuose ar žiūrint iš paukščio skrydžio. Lazdynų mikrorajone svarbiausia - judejjimo metu atsiveriančios daugiaplanès perspektyvos, žmogiškasis mastelis (Mačiulis 2011).

Kaip jau minèta, svarbus kritinio regionalizmo bruožas - vietinei architektūrai būdingų medžiagu panaudojimas, jų tarpusavio derinimas. Subtiliu plytų ir medžio faktūrų derinimu išsiskiria E. N. Bučiūtės suprojektuota bendrojo lavinimo mokykla Naugarduko g., Vilniuje (1969 m.). Tai - viena pirmujų sovietmečio mokyklų statyta pagal individualų projektą (Tutlytė 2012). Tai galima paaiškinti netipine sklypo situacija. Esamas užstatymas nebuvo vieningas, be aiškaus morfologinio tipo, charakteringų bruožų, sklypas su nuolydžiu išsidèstęs ties judraus eismo gatvių sankirta. Netipinis projektas leido architektei eksperimentuoti ir subtilesnèmis meninès raiškos priemonemis. Konstrukcija išryškinta būdingo XX a. pradžios naujamiesčio architektūrai gelsvų plytų mūro 
pagalba, langų plokštumos pabrèžtos medinių dailylenčių apdaila (34 pav.). Kiti panašūs objektai: kolūkio centras Alksniupiuose (archit. A. Mačiulis 19721981 m.) (35 pav.), klubas Palangoje (archit. R. ir A. Šilinskai 1979 m.), knygynas Palangoje (archit. R. V. Kraniauskas 1969 m.) Mokslų akademijos bibliotekos priestatas Vilniuje (archit. A. Brusokas 1974 m.), Maltos ordino pensionatas Kaune (archit. A. Kančas 1985 m.), kultūros namai Trakuose (archit. A. Paulauskas 1985 m.), poilsio namai „Banga“ Šventojoje (archit. N. Blaževičienė 1988 m.) ir kt.
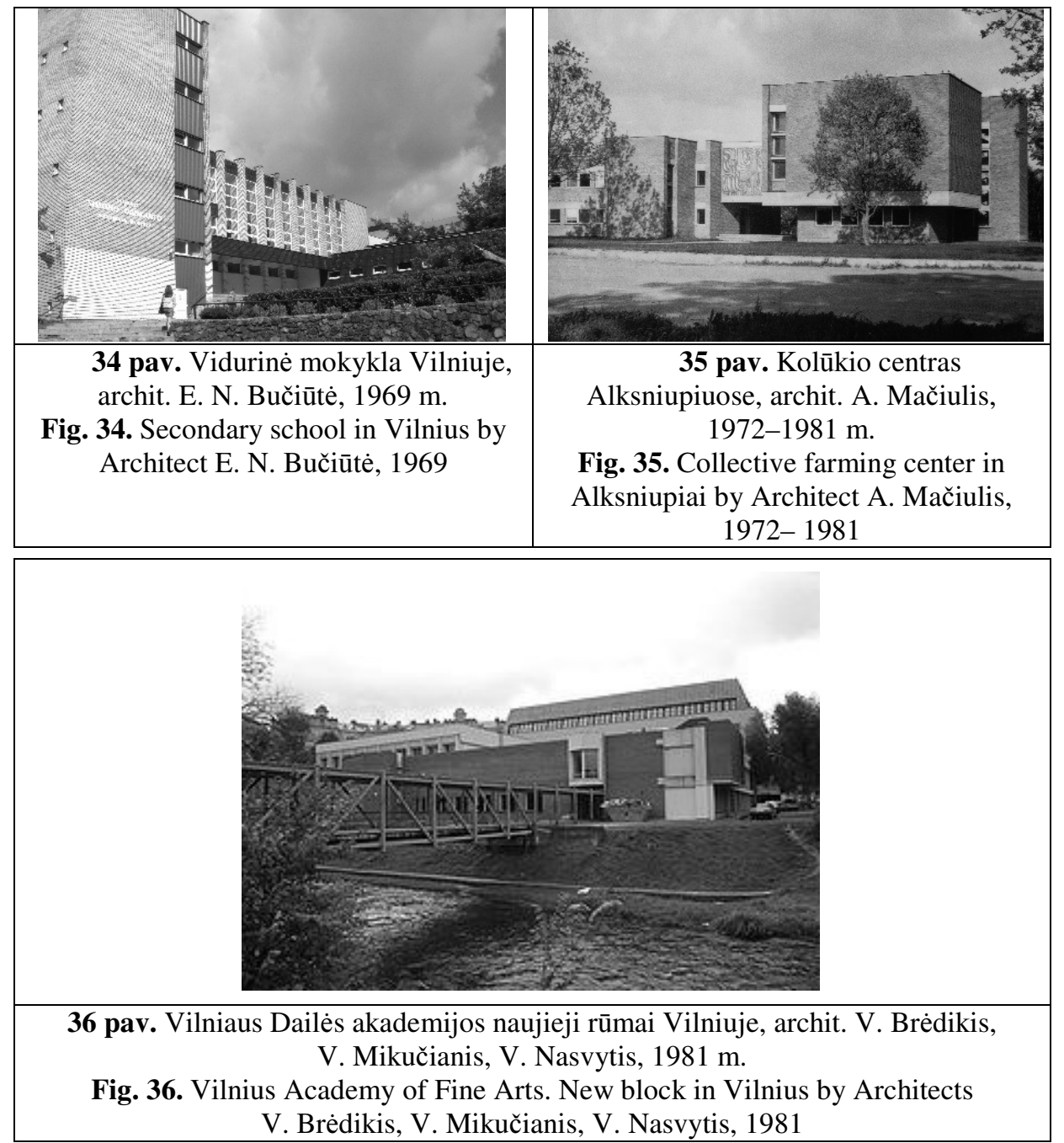

Išskirtinè gamtinè situacija, istoriškai susiklosčiusi Užupio rajono urbanistinė situacija Vilniuje, suformavo išskirtinę užduotị Vilniaus dailès akademijos 
naujujų rūmų architektams V. Brèdikiui, V. Mikučianiui ir V. Nasvyčiui (1981 m.) (36 pav.). Šị kompleksą sunku būtų įvardinti kaip stilistiškai vieningą, nors urbanistiniu požiūriu jis papildè gamtovaizdị, masteliu nenustelbdamas aplinkinio užstatymo (Mačiulis 2007). Pastate galima išskirti tris pagrindinius tūrius, sujungtus tarpusavyje, tačiau meninès raiškos požiūriu, turinčius mažai ką bendro. Aukštesnysis korpusas - trijų aukštų su mansarda - formuoja senamiesčio posesiją su vidiniais kiemeliais, mansardiniu stogu. Mažesnis - sporto salès korpusas. Jame galime ižvelgti vèlyvajam modernizmui būdingo monumentalumo, pasikartojantys langų ritmai, masyvios plytų mūro plokštumos formuoja solidumo įspūdị. Pastato faktūros ir spalvos atspindi kompleksišką statinio idèją. Raudonų plytelių apdaila simbolizuoja ryši su kitoje Vilnelès pusèje išsidèsčiusiu Bernardinų, Onos bažnyčių ansambliu, spalvinga tinko apdaila senamiesčio posesijas.

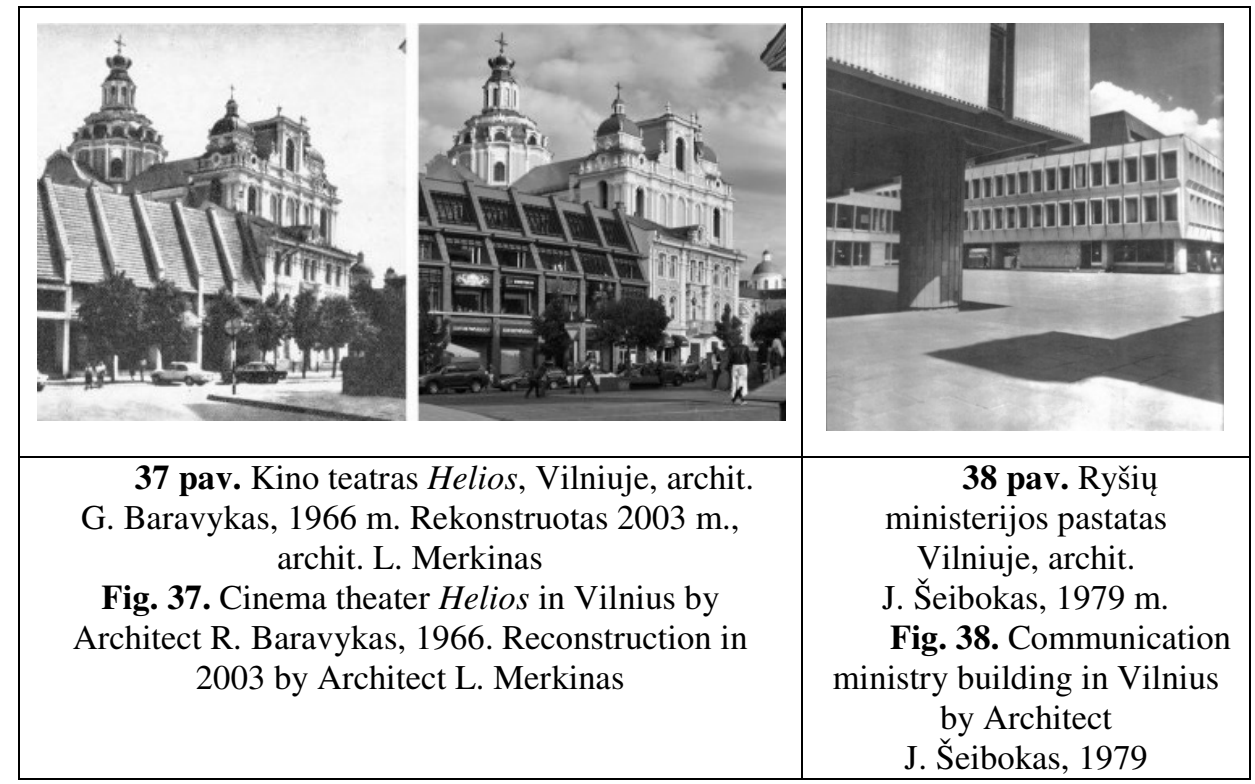

Panašios meninès raiškos priemonių panaudojimo pavyzdys architektūroje, reaguojant $\mathfrak{i}$ istorinę aplinką, galètų būti architekto G. Baravyko suprojektuotas kino teatras „Helios“ (1966 m., rekonstruotas 2003 m., archit. L. Merkinas) (37 pav.). Šis pastatas, dèl itin jautraus konteksto, atspindi kritinio regionalizmo principus faktūrų ir spalvų santykiu. Čerpiniai stogai, plytų faktūra, tinko ir stiklo santykis taikèsi prie aplinkinio užstatymo, o tūrinè - erdvinè kompozicija jau atspindèjo vèlyvojo modernizmo principus. R. Buivydo teigimu, dominuojantis raudonų čerpių stogas - siena atkartoja senamiesčio pastatų charakterị, fasade akcentuotas pilonų ritmas, architekto teigimu, reflektuoja šalia esančios Rotušès kolonadą. Nors šis objektas ir buvo kritikuojamas kolegų dèl „pataikavimo 
istorizmui“, šiandien jis yra suvokiamas kaip saikinga praeities architektūros interpretacija (Buivydas 1999a).

Kontekstualaus kritinio regionalizmo pavyzdys, jau turintis ir vèlyvajam modernizmui būdingo plastiškumo, būtų J. Šeiboko suprojektuotas Ryšių ministerijos pastatų kompleksas (dabar Sveikatos apsaugos ministerija) Vilniaus g., Vilniuje (1979 m.) (38 pav.). Pastatas surinktas iš tipinių elementu, tačiau siekiant kontekstualumo istorineje aplinkoje, fasadų meninè raiška išspręsta skirtingomis kompozicinèmis priemonèmis, kai kur matomos dekoratyvumo tendencijos. Aklinas Islandijos g. fasadas apdailintas betoniniais bareljefais, Vilniaus gatvès fasadas surinktas iš tipinių sienos - lango elementų, vidinis korpusas apdailintas sieniniais surenkamais paneliais. Pastatas atkartoja senamiesčio posesijas savotiškai interpretuodamas vidini kiemą, kuris i Vilniaus g. pusę yra pusiau atviras. Panašiu „vidinio kiemo“ principu ir dekoratyvia fasadų raiška pasižymi ir Seimo rūmų kompleksas (archit. A. ir V. Nasvyčiai 1981 m.) (39 pav.), kuriame pasirinktas monumentalus, griežtas fasadų raiškos būdas. Apie moderniosios Lietuvos architektūros dekoratyvejjimą yra rašę R. Buivydas (Buivydas 1999b), A. Mačiulis (Mačiulis 2002), V. Petrulis (Petrulis 2006) ir kt.

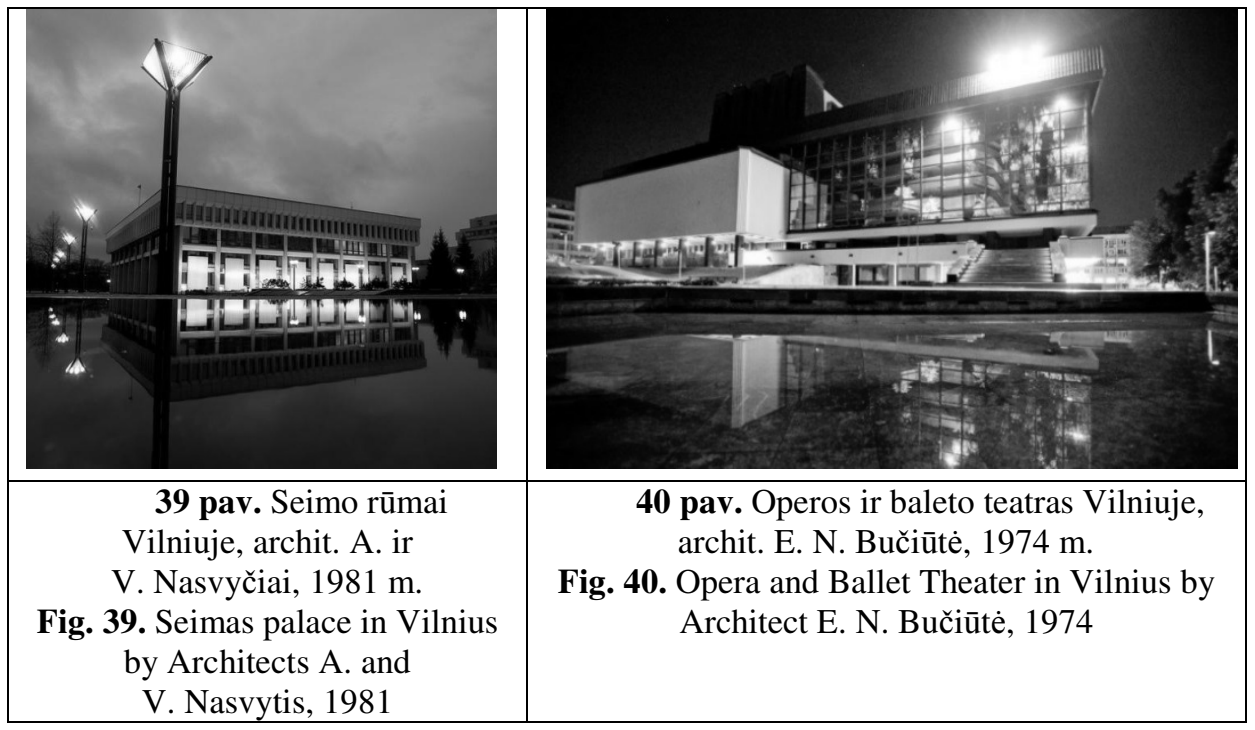

Dekoratyvi, fasadiška architektūrinè raiška atspindejo kritinị regionalizmą kontekstualumo ir interpretacijos aspektu. Pavyzdžiui, Vyriausybès rūmų pastate (archit. V. E. Čekanauskas 1976-1982 m.) dekoratyvia, laužyta fasadų plastika siekta sumažinti naujo pastato tūrị istorinèje aplinkoje. Panašūs sprendimai pastebimi Seimo rūmų II-ajame (archit. A. Gudaitis 1978 m.) ir III-ajame (archit. Ć. Mazūras 1979 m.) korpusuose. Unikaliu aptariamam laikotarpiui 
medžiagiškumu, kartu ir skultpūrinèmis interjero detalèmis bei dekoratyviais elementais fasaduose, išsiskiria Operos ir baleto teatras Vilniuje (archit. E. N. Bučiūtè, 1974 m.). Kaip teigia R. Buivydas: „šis objektas imponavo mūsų architektūroje gana reta teatrališkai ištaiginga išraiška, ispūdingais išorès ir vidaus parametrais“ (Buivydas 2006). Pastato erdviniai sprendimai artimi tarptautinio stiliaus funkcionalumui, tačiau vietinị charakteri atspindi skulptūriškas medinių interjero balkonu sprendimas (matomas ir iš išorès), masyvus karnizas, skulptūrinè plastika fasaduose. Operos ir baleto teatro architektūrinè raiška sukuria įspūdi, tarsi visas interjero teatrališkumas būtų uždengtas stikliniu gaubtu (40 pav.).

Kritinis regionalizmas Lietuvos architektūroje modernizmo ir vėlyvojo modernizmo stilių ịtakoje išlaikè tris pagrindinius šios krypties meninès raiškos bruožus:

- vietinei architektūrai būdingų medžiagų naudojimas;

- kontekstualumas;

- vietinès architektūros interpretacija.

Tautiškumo aspektas Lietuvos architektūroje. Tautinès (kitur vadinamos vietine $^{4}$ ) architektūros nagrinejjimas stilistiniu aspektu yra pakankamai sudètingas uždavinys, kadangi tautiné architektūra yra linkusi būti savaiminiu reiškiniu, jos sąlytis su projektuotoju dažniausiai yra minimalus. Tai lemia, jog tautinè architektūra, kaip savarankiška kryptis, turètų būti nagrinèjama atskirai nuo visų kitų krypčių, kadangi ji nèra kūrybos tikslas, ji dažniausiai yra aplinkinių faktorių ittakos rezultatas, atspindys. Tautinèje architektūroje žmogaus, kaip tiesioginio architektūros vartotojo menkai paisoma. Kaip teigia tautinès architektūros tyrinètojas Paul Olivier: ,tautinę architektūrą galima apibrěžti kaip tautos architektūrą, kuriamą žmonių, tačiau ne žmonėms“" (Olivier 2003). Galima daryti prielaidą, jog tautinè architektūra, kuriama architektų jau nebèra tautiné, juk tik tikslingas objekto projektavimas paverčia ji profesionaliu architektūros kūriniu, kuo tautinès architektūros objektas nèra.

Lietuvoje, kaip teigia V. Jukštas (1976) taip pat A. Mačiulis (1999), tautinès architektūros situacijos unikalumą sąlygojo politinis kontekstas. Gali būti, jog tautinių elementų, naratyvių formų, įvairių etnografinių motyvų stilizacijų naudojimas buvo savotiška rezistencijos forma, galbūt tautinio savitumo paieška, emigracijoje - tautinio identiteto išsaugojimo būdas. Taigi, siekiant apibrěžti, kokia tautinè architektūra gali būti nagrinèjama šiame tyrime stilistiniais aspektais, nagrinèsime išskirtinai profesionaliai sukurtus objektus ir laikysime juos savotiška regionalizmo kryptimi.

Sovietmečio architektūros Lietuvoje tyrinètojas V. Petrulis tautiškumo idèjas Lietuvos architektūros meninèje raiškoje sieja su tradicijomis, būdingomis

${ }^{4}$ Vernacular (angl.) 
konkrečiam regionui ar miestui. Tradicijos architektūroje galejo pasireikšti tiesioginiu ir netiesioginiu vietinių statybos elementu panaudojimu, tautinių elementų stilizacijomis, vietine simbolika, šių elementų ir modernių statybos priemonių derinimu tarpusavyje, dažnai pereinant prie naratyvaus dekoratyvumo (Petrulis 2005).

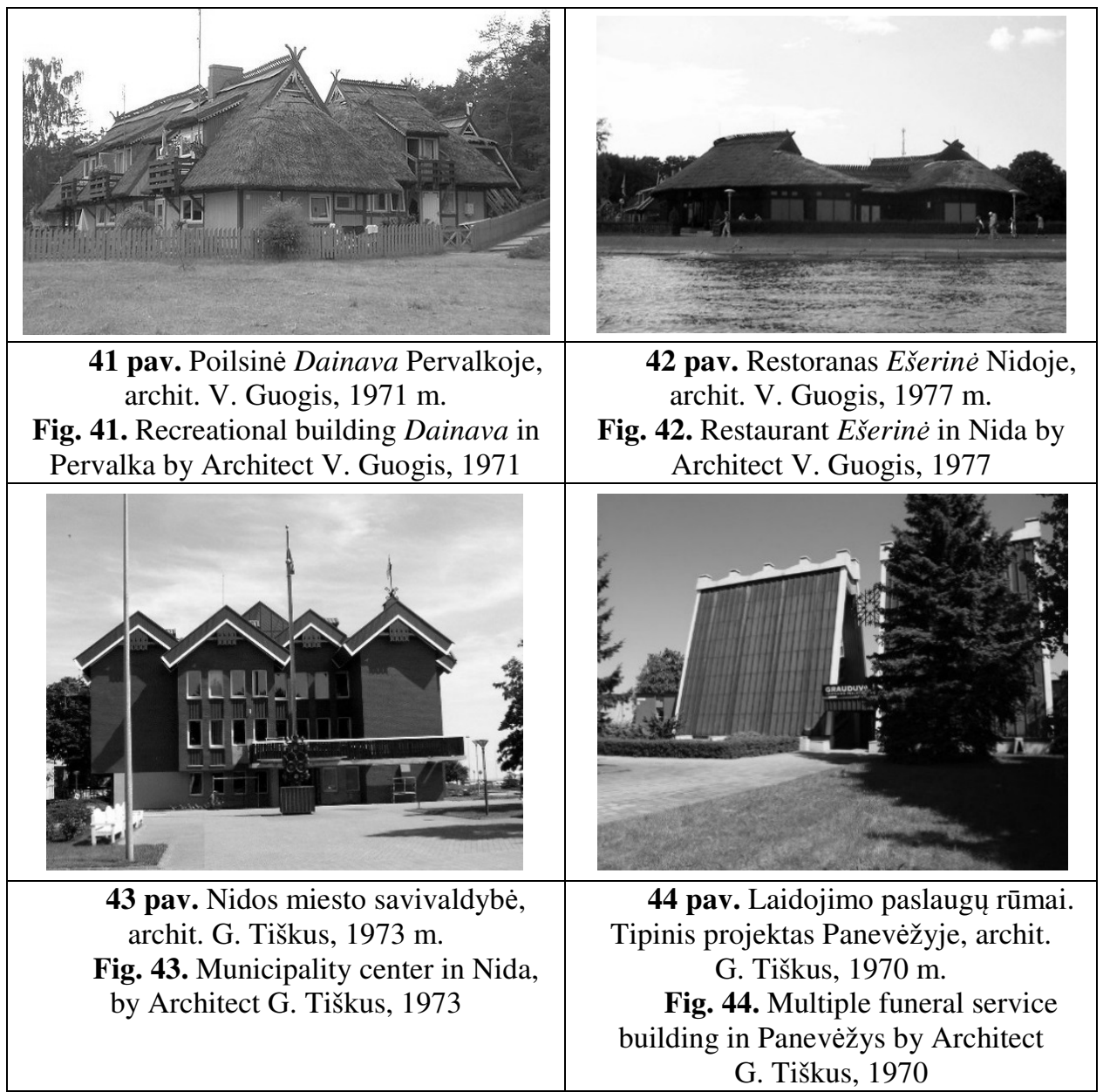

Tarp reikšmingesnių tautinès architektūros objektų reikètų paminèti: naratyvia pajūrio architektūros formų interpretacija pasižyminčius poilsio namus „Dainava“ Pervalkoje (archit. V. Guogis 1971 m.) (41 pav.), kavinę „Vaidilute“", Palanga (archit. G. Tiškus 1970 m.), restoraną „Ešerine““ Nidoje (archit. V. Guogis 1977 m.) (42 pav.). Taip pat, gydomaji kompleksą Juknaičiuose (archit. A. Kiškis ir kt. 1974 m.). Šiek tiek labiau stilizuotomis formomis pasižymejo architekto Gyčio Tiškaus projektuotas savivaldybès pastatas Nidoje (1973 m.) (43 pav.) ir 
tipinis laidojimo namų projektas (1973 m.) (44 pav.), Eugenijaus Arkušausko projektuota kavinè „Du gaideliai“ Klaipedoje $(1974 \mathrm{~m}$.) ir daugiabutis gyvenamasis namas Klaipedoje (1975 m.), taip pat gyvenamieji namai Nidoje (archit. V. Raginis ir V. Stauskas 1974 m.) ir kt.

\subsection{Meninès raiškos priemonès ekspresyvumo ir plastiškumo paieškose.}

Penktojo dešimtmečio viduryje pasaulinèje architektūroje pradedama jausti tarptautinio stiliaus krize, kuri pastebima to meto publikacijose. Visu pirma kritikuojamas tarptautinio stiliaus nepaslankumas, negebejimas keistis ir prisitaikyti prie kintančių poreikių, tuo pačiu - individualumo trūkumas. Bruno Zevi straipsnyje „Towards an Organic Architecture“ (1945 m.) teigia, jog funkcionalizmas neturi teorinio pagrindo. Atsiradęs kaip priešprieša tradicinei architektūrai jis tapo universaliu, tarptautiniu stiliumi tačiau būdamas universalus, iš esmès nebegali kisti (Zevi 2008). B. Zevi vèliau pritarè ir Pablo Bonta, tiesa daugiau socialiniu aspektu. Straipsnyje „Architecture and its Interpretation“ (1977 m.), kur analizuojant tarptautinio stiliaus ir socialinès aplinkos tarpusavio ryšius ir prieinama išvados, jog tarptautinio stiliaus žlugimas buvo užprogramuotas nuo pat jo atsiradimo, nes jis negalejo keistis ir prisitaikyti (Bonta 1977). Matthew Nowicki straipsnyje „Origins and Trends in Modern Architecture“ (1951 m.) teigia, jog pasirodžius Le Corbusier „Modulior“, kuris nagrinejja ergonomines būsto savybes, architektūra pagaliau perkopè iš kiekybinio i kokybini aspektą ir tuo perženge tarptautinio stiliaus ribas. Remiantis aukso pjūvio proporcijomis jau kalbama ne apie funkciją, o apie estetiką (Mumford 1972).

Meninès raiškos požiūriu, išsamiausią vėlyvojo modernizmo laikotarpio apžvalgą ir analizę atliko Charles Jencks (Jencks 1982). Siekdamas atskirti postmodernizmą nuo modernizmo jis apibrěžè vèlyvojo modernizmo sąvoką nurodydamas pagrindinius šio stiliaus meninès raiškos bruožus. Ch. Jencks teigimu, vèlyvajam modernizmui būdinga tūrių, ir funkcijos hiperbolizacija ir kraštutinumai, siekiant i̇domesnès architektūrinès raiškos, norint išvengti monotonijos. Ne visi Ch. Jencks išvardinti vèlyvojo modernizmo bruožai būdingi Lietuvos architektūrai, pavyzdžiui techninè estetika (su keliomis išimtimis), pasireiškė jau tik nepriklausomybès laikotarpiu, tačiau kai kurie jų yra aiškiai pastebimi nagrinèjamo laikotarpio Lietuvos architektūros meninejje raiškoje:

- plastinių formų naudojimas;

- geometrinių formų ekspresija;

- artikuliuoti pasikartojimai. 
Šiuos bruožus tikslinga nagrinèti atskirai, kadangi kai kuriose jų susiformavo tokios architektūros kryptys kaip brutalizmas ar struktūralizmas, aiškiai pastebimos ir Lietuvos architektūroje, kai kurios jų jau anksčiau nagrinètos ir moksliniuose tyrimuose.

Skulptūriškumas. Plastika. Nepaisant to, jog buvo priskiriamas racionalios, tarptautinio stiliaus architektūros krypčiai, Le Corbusier savo kūrybos finale suprojektavo ekspresyvią, absoliučiai iracionalią koplyčią Ronchamp vietoveje, Prancūzijoje (1950-1955 m.) (45 pav.). Piešiniai ant stiklo, emalio paneliai bei sienų apmušalai turi aliuzijų i saulę, sezonų kaitą, vyrišką ir moterišką pradą, šviesą ir tamsą. Visas šis kosminis simbolizmas išreikštas sunkia, primityvia, iš dalies brutualia, iš dalies tragiška, o iš dalies ir linksma geometrinių formų susikirtimo jèga (Jencks 1982).

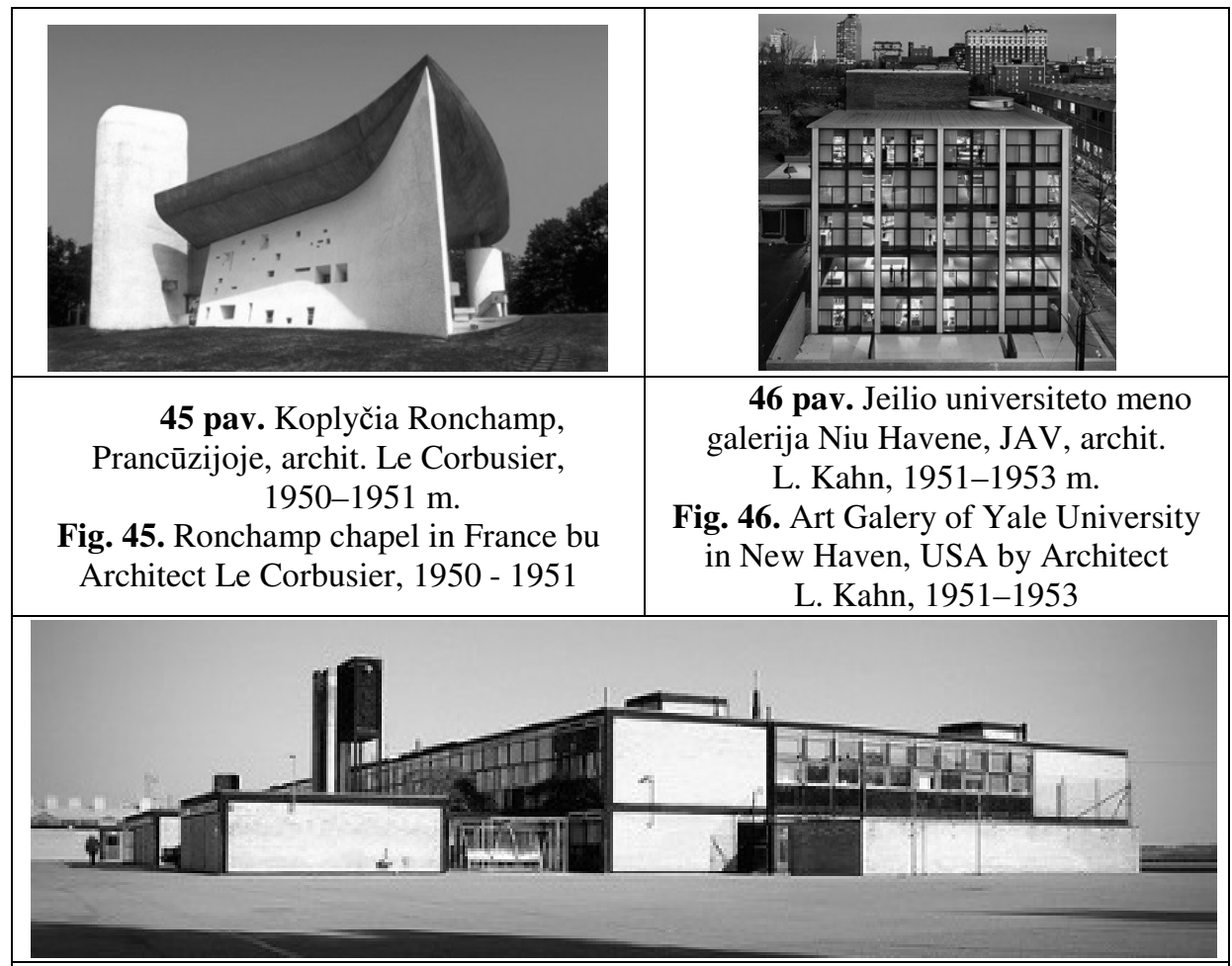

47 pav. Hunstantono mokykla Norfolke, Anglijoje, archit. P. ir A. Smithson, 1949-1954 m.

Fig. 47. Hunstanton school in Norfolk, England by Architect P. and A. Smithson, 1949-1954

Ronšano koplyčia pabrèžè funkcija pagrịsto, racionalaus stiliaus krizę dvejais aspektais. Visu pirma, pasak James Stirling, koplyčios kuriamas įspūdis visiškai nesusijęs su racionalia tarptautinio stiliaus menine raiška, čia nieko nèra logiško, 
racionaliai paaiškinamo. Vizualinis įspūdis kuriamas iracionalaus atsitiktinumo ir netikètumo, sustiprintas aiškiai artikuliuota simbolika. Antra, tai formos plastika ir skulptūriškumas (Stirling 1997). Šis objektas iš esmès leido išskirti idejinị ir formaluji architektūros pradą. Postmoderniojoje architektūroje iš šio objekto buvo adaptuotas metaforiškasis aspektas, simbolių kalba, vėlyvajame modernizme - formalusis, t. y. skulptūriškumas ir plastika (Jencks 1982).

Reyner Banham naujają, skulptūrinę architektūrinę raišką pirmą kartą apibūdina kaip Naujaji brutualizmą (1955 m.), kurio ženklų aptinka vèlyvuosiuose Le Corbusier darbuose, P. ir A. Smithson projektuotoje Hunstantono mokykloje Norfolke, Anglijoje (1949-1954 m.) (47 pav.) ir Jeilio universiteto meno galerijoje Niu Havene, JAV (1951-1953 m.), projektuotoje L. Kahn (46 pav.). R. Banham tuo pačiu apibrěžia pagrindinius brutualistinès architektūros principus:

- isimintina, dominuojanti forma;

- konstrukcinès sąrangos eksponavimas pastato architektūrinèje raiškoje;

- medžiagų natūralumas, apdailos nebuvimas.

İsimintina ir dominuojanti forma veikia emocijas, struktūros eksponavimas rodo santykị tarp pastato dalių, pabrèžia proporcijas, o medžiagų natūralumas atskleidžia konkretaus laikotarpio technines galimybes (Banham 2008a). Brutalizmo architektūros tūrinè išraiška galèjo būti pati ịvairiausia - nuo plastinių gelžbetonio formų, iki griežtų, statmenai susikertančių tūrių. Didžiausią vaidmeni, kaip ir visuose vèlyvojo modernizmo objektuose, atliko formų hiperbolizacija.

\begin{tabular}{|c|c|c|}
\hline & 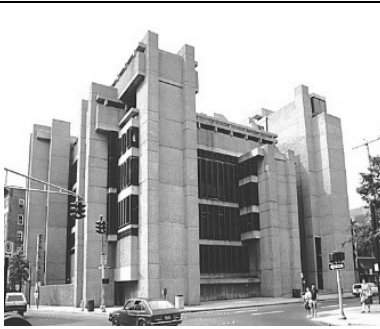 & 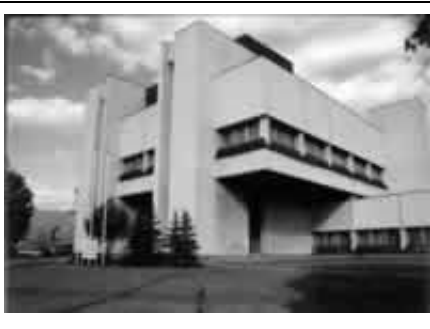 \\
\hline $\begin{array}{c}48 \text { pav. } \\
\text { Kompozicija Anti- } \\
\text { konstrukcija, } \\
\text { T. van Doesburg, } \\
1923 \text { m. } \\
\text { Fig. 48. Composition } \\
\text { Contra - Construction } \\
\text { by T. van Doesburg, } \\
1923\end{array}$ & $\begin{array}{c}49 \text { pav. Jeilio } \\
\text { universiteto Meno ir } \\
\text { architektūros fakultetas } \\
\text { Niu Havene, JAV, archit. } \\
\text { P. Rudolph, } 1963 \text { m. } \\
\text { Fig. 49. Yale University, } \\
\text { Faculty of Art and } \\
\text { Architecture in } \\
\text { New Haven, USA, by } \\
\text { Architect } \\
\text { P. Rudolph, } 1963\end{array}$ & $\begin{array}{l}\mathbf{5 0} \text { pav. VRM kultūros } \\
\text { rūmai Vilniuje, archit. } \\
\text { A. Mačiulis, } 1982 \mathrm{~m} \text {. } \\
\text { Fig. 50. Culture center of } \\
\text { Ministry of Internal Relations } \\
\text { in Vilnius, by Architect } \\
\text { A. Mačiulis, } 1982\end{array}$ \\
\hline
\end{tabular}


Paul Rudoph projektuotas Jeilio universiteto, Meno ir architektūros fakulteto pastatas Niu Havene, JAV (1963 m.) (49 pav.) yra vienas pirmujų objektu, pasižyminčiu hiperbolizuota skulptūrine forma, pasak Ch. Jencks, primenančią erdvines De Stijl menininkų erdvines improvizacijas (48 pav.) ir vèlyvuosius Le Corbusier darbus (Jencks 1982). Architekto Algimanto Mačiulio projektuotas VRM kultūros rūmų pastatas Vilniuje $(1982$ m.) (50 pav.) pasižymi tvirta proporcine struktūra, (Palaima 2006) brutualesne estetika, griežtesniais, apibendrintais tūriais, tačiau išreiškia panašią hiperbolizuotą skulptūrinę formą. Horizontalus betoninis tūris tarsi įstrigęs tarp vertikalių laikančių atramų. Tamsi langu linija ir dekoratyvus fasado skaidymas sukuria šviesos - šešèliu žaismą. Tamsios skardos intarpai, o taip pat ir viršuje ištrauktas koncertinès salès tūris pabrèžia pastato daugiaplaniškumą. Nors laiko skirtumas tarp šių objektų - beveik 20 metų, aiškiai matomi panašūs architektūrinès formo kūrimo principai.

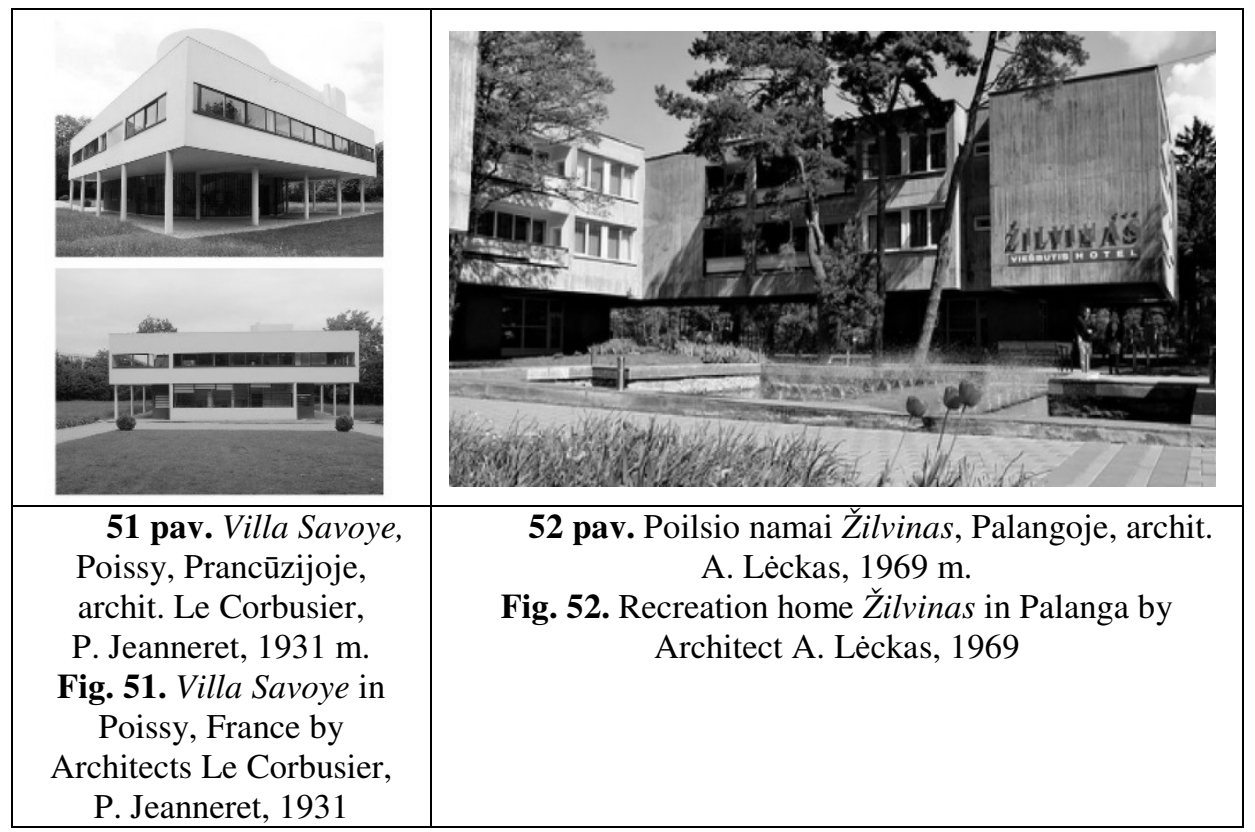

Algimanto Lècko projektuotas poilsio namų „Žilvinas“ kompleksas Palangoje (1969 m.) (52 pav.), dèl tuometinių konstrukcinių ir architektūrinių sprendimu palankiai vertintas Lietuvos architektu, taip pat priskiriamas brutalistinei vèlyvojo modernizmo krypčiai. Šiame objekte hiperbolizuojama Le Corbusier „pakelto namo“ ideja (51 pav.) (Dremaite, et. al. 2012). Šis objektas išsiskiria sudètingais konstruktyviniais sprendimais, dèl kurių antrasis ir trečiasis pastato aukštai tarsi pakabinti ant dviejų atramų, paliekant laisvą erdvę apačioje. Tai rodo jautru architekto požiūri i gamtą, prisitaikymą prie esamos situacijos. Estetiniais tikslais palikta betono klojinių faktūra pabrěžia pastato struktūrą bei 
formuoja įsimenančią betono estetiką. Raudono plytų mūro atramos kontrastuoja su šviesiu pakabintu tūriu ir tarsi išnyksta pušyno fone.

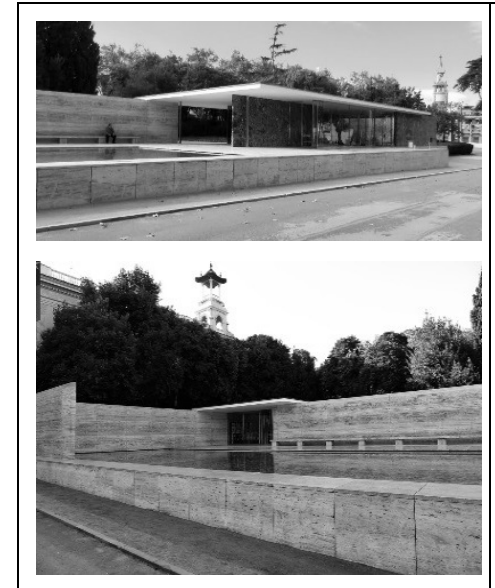

53 pav. Vokietijos

paviljonas 1929-ujų EXPO parodai Barselonoje, Ispanijoje, archit.

L. Mies van der Rohe

Fig. 53. German pavilion for 1929 EXPO in Barcelona, Spain by Architect L. Mies van der Rohe

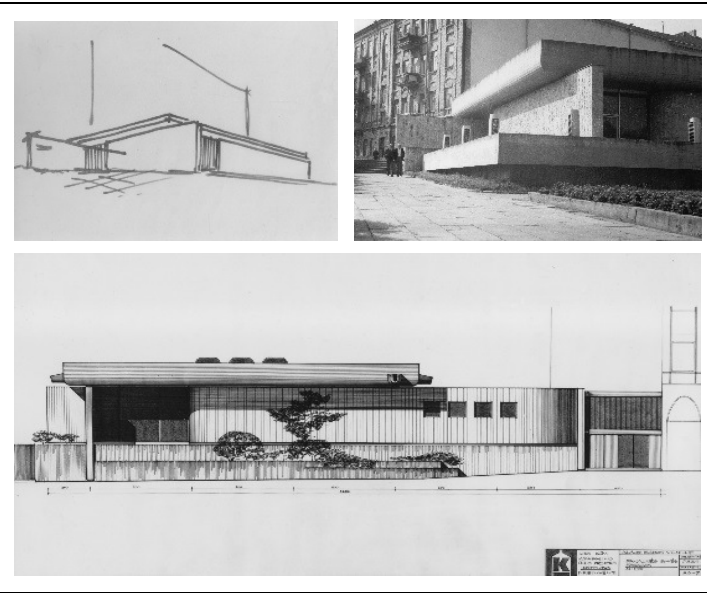

54 pav. Alaus baras Tauro Ragas Vilniuje, archit. A. Mačiulis, $1974 \mathrm{~m}$.

Fig. 54. Beer pub Tauro Ragas in Vilnius by Architect A. Mačiulis, 1974

Tarptautinio stiliaus tūrinès kompozicijos ir architektūrinių elementų hiperbolizacijomis pasižymi buvęs alaus restoranas „Tauro ragas“ (archit. A. Mačiulis 1974 m.) (54 pav.). Funkcionaliai išdèstytos erdvès suskirstytos pusiau atviromis pertvaromis, tarp kurių atsirandantys stiklo intarpai pabréžia laisvo planavimo principus. Pirminiame architekto eskize matomos pagrindinès proporcijos, būdingos brandžiąam tarptautiniam stiliui (53 pav. pavaizduotas Vokietijos paviljonas 1929-ujų Barselonos EXPO parodai Ispanijoje projektuotas architekto L. Mies van der Rohe). Galutinis projekto variantas - formų hiperbolizacija. Horizontali, tačiau jau masyvesnè ir plastiškesnè stogo plokštuma su lenktomis sienomis sukuria šviesos-šešèlių žaismą. Grubios faktūros betonas ir tamsus stogas sustiprina kontrastą, išryškina skirtingų pastato elementų funkcijas. Šis objektas - vienas ryškesnių Lietuvos brutalistinès architektūros pavyzdžių.

Ekspresyvi, skulptūriška brutualizmo estetika matoma Vilniaus Koncertų ir sporto rūmų (archit E. Chlomauskas, J. Kriukelis, Z. Liandzbergis 1971 m.) (55 pav.) architektūros meninejje raiškoje. Pastato stogo konstruktyvinis sprendimas (vantinè konstrukcija) atspindejjo tuometines sporto kompleksų statybos tendencijas Sovietu sajungos valstybèse (panašūs sprendimai panaudoti 
Minsko, Biškeko sporto rūmų konstruktyviniuose sprendimuose), tačiau architektūrinès raiškos vientisumas atspindejo pasaulines brutalizmo tendencijas. Betono plastika ir pilkų dolomito plokštelių intarpai pabrèžè vientisą skulptūrinę formą, kuri nenutrūkstamai pereina iš vidinių erdvių i išorę ir formuoja lengvai atpažįstamą pastato charakterị. Stiklo plokštumos pridengia vidines erdves, tačiau nedominuoja pastato struktūroje. İdomus yra galinio pastato fasado architektūrinis sprendimas. Tarsi kompozicine atsvara pagrindiniam lenktam fasadui formuojamas dekoratyvus skulptūrinis elementas, pabrèžiantis horizontalumą ir taip išryškinantis vertikalius laikančiuosius elementus. Panašų architektūrinị sprendimą galima aptikti administracinio pastato Čandigare, Indijoje, fasade, projektuotame La Corbusier (1955 m.) (56 pav.).

\begin{tabular}{|c|c|}
\hline E5 pav. Vilniaus Koncertų ir sporto rūmai, archit. & $\begin{array}{c}\text { 56 pav. Vietinès } \\
\text { valdžios administracinis } \\
\text { pastatas Čandigare, } \\
\text { Indijoje, archit. }\end{array}$ \\
Fig. 55. Sport and Concert palace in Vilnius by \\
Architects E. Chlomauskas, J. Kriukelis, \\
Z. Liandzbergis, 1971 Corbusier, 1955 m. \\
Fig. 56. \\
$\begin{array}{c}\text { Administrative Building } \\
\text { of local authorities in } \\
\text { Chandigarh, India, by } \\
\text { Le Corbusier, 1955 }\end{array}$ \\
\hline
\end{tabular}

Plastiškų formų brutalizmo estetika pasižymejjo ne tik hiperbolizuotomis tarptautinio stiliaus architektūros formomis, tačiau ir jautresne architektūrine raiška (Frampton 2007). Dažnai plastinèse formose buvo galima įžvelgti ne tik sparno, burès, paukščio ar kokio kito objekto metaforą. Plastiškos brutualistinès betoninès formos, dažniausiai paremtos tokiomis pat betoninèmis kolonomis teigè, jog visą architektūrinę raišką galima kurti vienos medžiagos pagalba, taip dar labiau sustiprinant skulptūriškumo ịspūdị (Jencks 1982). Plastiška, bioninių formų architektūrinè raiška matoma Eero Saarinen suprojektuotame Jeilio universiteto ledo ritulio stadione Konektikute, JAV (1953-1959 m.) (57 pav.), oro uosto terminaluose Niujorke, JAV (1956-1962 m.) (57 pav.) ir Virdžinijoje, JAV (1958-1962 m.) ir kt. Panašia estetine raiška pasižymi Vasaros estrados pastatas Palangoje (archit. V. Gerulis 1970 m.) (59 pav.). Lenkta stogo plokštuma primena išskleistus paukščio sparnus, pasvirusios atramos, kolonų ir sijų tinklas atkartoja aplink augančių medžių ažūrą. Masyvus arenos tūris papildomai skaidomas 
horizontalėmis. Sąlyčio su gamta jausmą sustiprina medinių detalių panaudojimas.

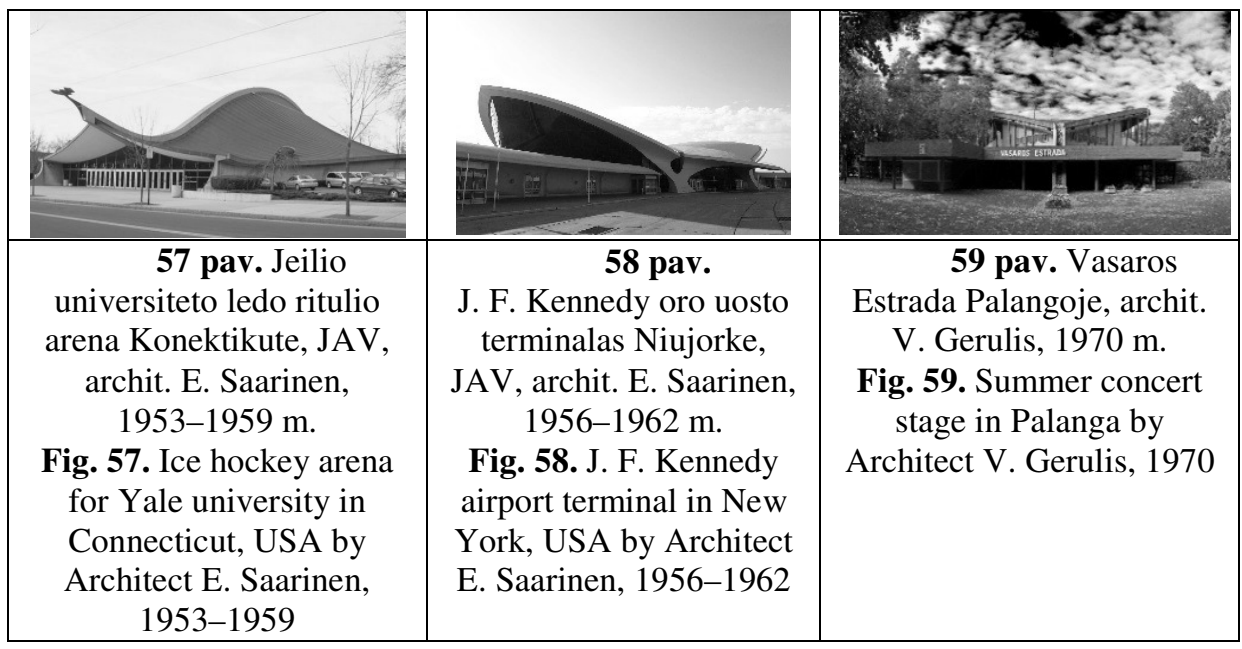

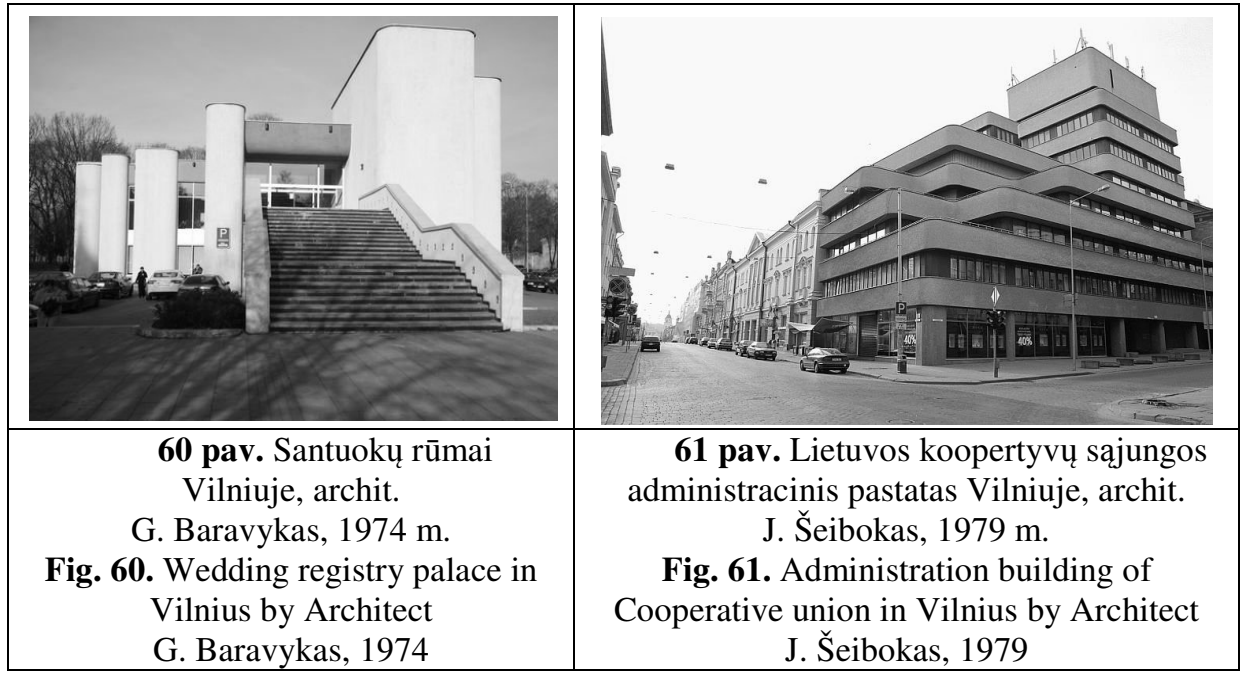

Brutalizmo tendencijos svariai prisidejo prie plastišku formų naudojimo proveržio Lietuvos architektūroje. Pasak A. Mačiulio, aštuntojo dešimtmečio viduryje, Gediminui Baravykui suprojektavus Santuokų rūmus Vilniuje (1974 m.) (60 pav.), Lietuvos architektūroje pradejjo ryškèti iracionalumo bei ekspresyvumo tendencijos, nutolusios nuo brutalistinès estetikos, tačiau vis dar įmantriai hiperbolizuojančios modernistinius planinius ir tūrinius sprendimus. Pastatų kompozicijoje ėmė vyrauti „skulptūrinès, dekoratyvinės formos“ (Mačiulis 2002). Nagrinèjant Santuokų rūmų planinę - erdvinę sąrangą akivaizdu, jog plastinès formos svarbios tik architektūrinei raiškai pagyvinti, svarbiausias 
elementas - atvira, funkcionali, bet hiperbolizuota planinè struktūra kuri atsispindi pastato išorèje. K. Gerliakas teigia, jog G. Baravyko architektūros išskirtinumą lèmé ir savotiškas jo kūrybos proceso braižas. ,Jam buvo svetimas aplikacinis fasadu kūrimo būdas. G. Baravykas turejjo tuo pat metu mastyti apie pastato fasadus ir planinę struktūrą, nes pagrindinè meninès išraiškos priemonè buvo tūrinè forma, kuri glaudžiau susijusi su funkcija nei sąlyginai grafiškos aplikacijos" (Gerliakas 1996).

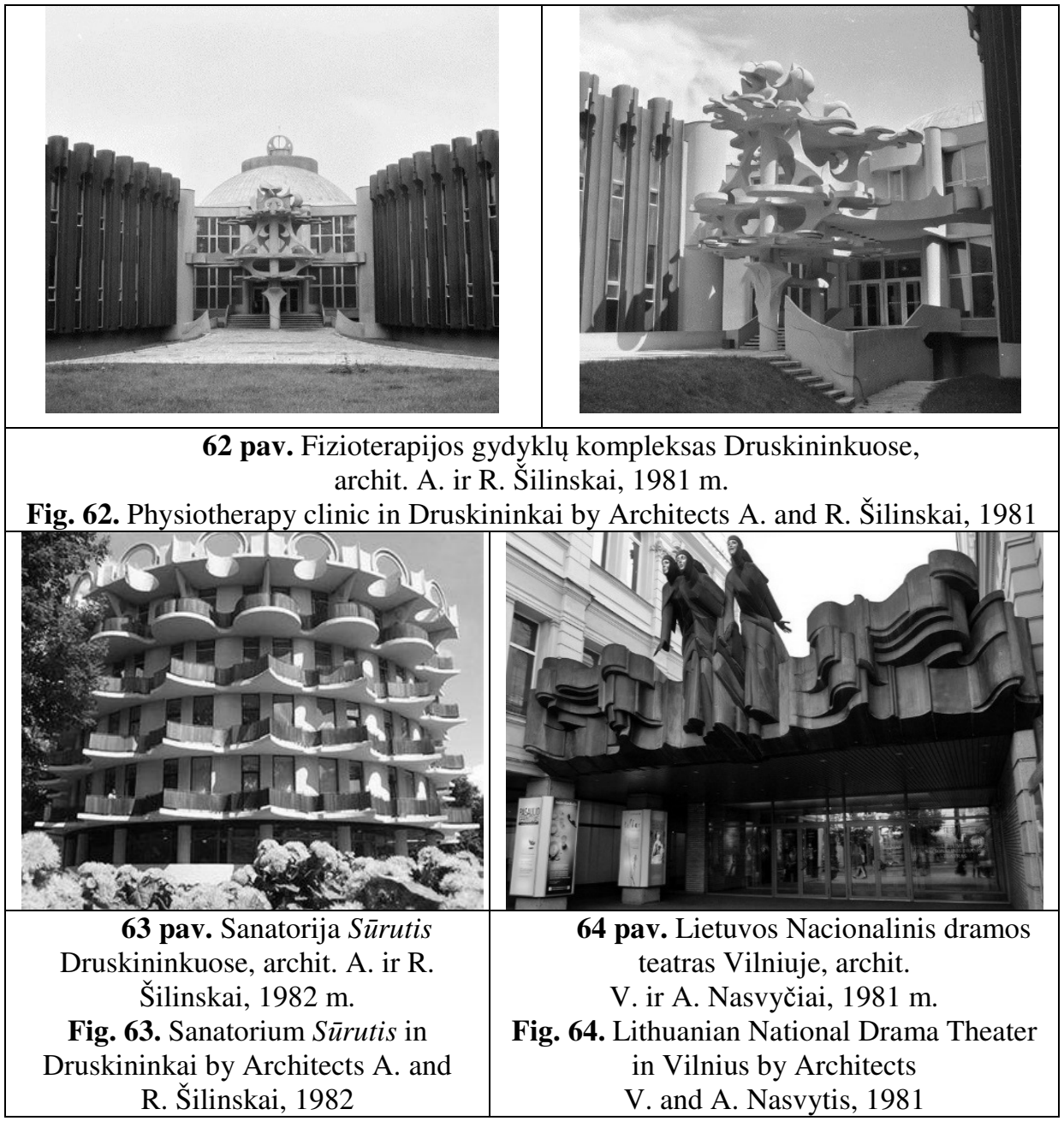

Plastiškomis skulpūrinèmis formomis ir artikuliuota planine struktūra pasižymi Žemès ūkio ekonomikos institutas Vilniuje (archit. V. E. Čekanauskas 1970 m.), turintis aliuzijų i strukturalistinę architektūrą (Nekrošius 2008). Kontekstualumu pasižymintis Lietuvos kooperatyvų sąungos administracinis 
pastatas (archit. J. Šeibokas 1979 m.) (61 pav.) plastiškomis skulptūrinėmis formomis ir horizontalia ritmika nuosaikiai įsilieja ị istorinị Vilniaus užstatymą. Kiti panašaus pobūdžio plastiškos architektūros pavyzdžiai: kultūros rūmai Perekšliuose (archit. H. Šilgalis 1972 m.), stomatologijos klinika Kaune (archit. I. Likšienė 1982 m.), parduotuvè „Rèda“ Kaune (archit. E. Miliūnas 1984 m.), planetariumas Vilniuje (archit. R. Stasėnas 1989 m.), vaikų darželis Alksniupiuose (archit. M. Mačiulis 1986 m.).

Hiperbolizuota skulptūrinè forma priartejjo prie dekoratyvumo architektams Aušrai ir Romualdui Šilinskams suprojektavus Fizioterapijos gydyklų kompleksą Druskininkuose (1981 m.) (62 pav.) ir vieną iš sanatorijos "Sūrutis" korpusų (1982 m.) (63 pav.). Fizioterapijos gydyklų komplekso architektūrinè raiška priartejo prie manierizmo fazès, kurioje interpretuojamos moderno, neobaroko formos, kuriose dominuoja aplikacija ir dekoratyvumas (Dremaite, et. al. 2012). Išskirtinai dekoratyviu skulptūriniu sprendimu pasižymi ir pagrindinis Lietuvos nacionalinio dramos teatro Vilniuje (archit. A. ir V. Nasvyčiai 1981 m.) fasadas (64 pav.). Pagrindinis iejjimas iš Gedimino prospekto - tik siaura, žema, stiklo pertvara jungianti senus namus, tačiau virš jos kylanti S. Kuzmos skulptūra „Mūzų šventė“ yra tikrasis teatro fasadas (Mačiulis 2007).

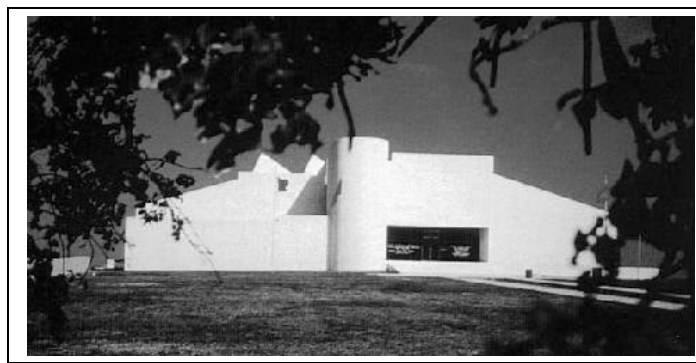

65 pav. Meno muziejus Teksase, JAV, archit. Ph. Johnson, $1972 \mathrm{~m}$.

Fig. 65. Art museum in Texas, USA by Architect Ph. Johnson, $1972 \mathrm{~m}$.

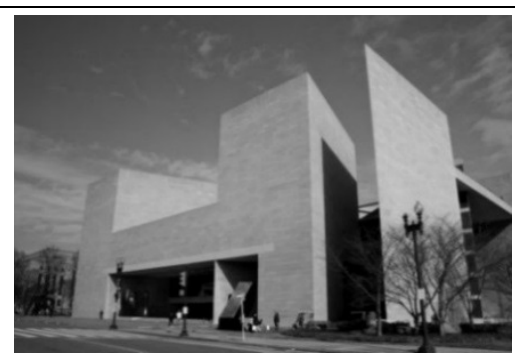

66 pav. Nacionalinès Meno galerijos Rytinis korpusas Vašingtone, JAV, archit.

I. M. Pei, $1978 \mathrm{~m}$.

Fig. 66. East block of National Art Gallery in Washington, USA by Architect I. M. Pei, 1978

Geometrinę ekspresiją architektūrinèje raiškoje galima kildinti iš brutalistinès ir ekspresionistinès XX a. architektūros. Ekspresyvios geometrinès raiškos tikslas vèlyvojo modernizmo architektūroje - hiperbolizuoti pirminių geometrinių formų naudojimą pastato menineje raiškoje, sukurti įtampą, nuostabą, konfliktą. Pagrindiniai geometrinès ekspresijos bruožai architektūrinèje raiškoje, remiantis Ch. Jencks (Jencks 1982):

- griežti, ryškūs kontūrai;

- pirminès geometrinès formos arba jų kompozicijos; 
- $\quad$ ekspresyvi raiška;

- formų priešprieša;

- $\quad$ hiperbolizacija (kaip ir visoje vèlyvojo modernizmo architektūroje).

Solidi, aiškių geometrinių formų meninè raiška pasaulinėje architektūroje dažniau pastebima verslo korporacijų pastatuose, tokia architektūra atspindèjo juc filosofiją, padejo kurti pageidaujamą reprezentatyvų, monumentalų ìvaizdi visuomenèje. Geometrinè ekspresija davė pradžią monumentaliai slick-tech paviršių raiškai, kuri Lietuvos architektūroje pasirodè tik XX a. pab.

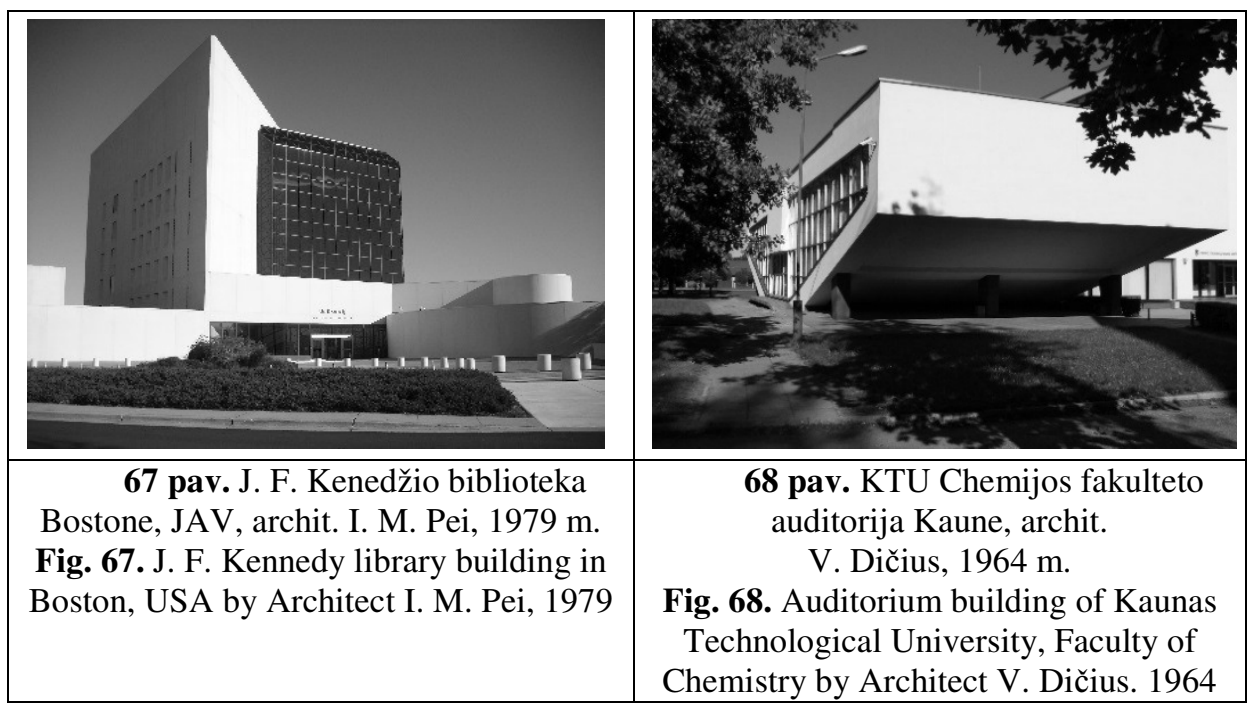

Ekspresyvia pirminių formų estetika pasižymintis muziejus Teksaso valstijoje JAV (archit. Ph. Johnson 1972 m.) (65 pav.) stebina beveik siurrealia precizika. Formų grynumas pabrèžiamas baltos spalvos tinko apdaila, nèra jokio skaidymo, jokių langu, o ir iejjimas tèra tarp formų atsiradusi ertmè. Panašūs architektūriniai sprendimai pastebimi ir architekto I. M. Pei darbuose, pavyzdžiui Nacionalinès meno galerijos Rytų korpuse, Vašingtone, JAV (1978 m.) (66 pav.), arba J. F. Kenedžio bibliotekos pastate Bostone, JAV (1979 m.) (67 pav.), kur baltai tinkuotų formų kompozicijoje akcentu paverčiamas tamsiu stiklu apgaubtas vestibiulis.

Vienas pirmųu įmantraus geometrinių formų naudojimo atvejis Lietuvos architektūroje pastebimas V. Dičiaus projektuoto KTU Chemijos fakulteto auditorijos (1964 m.) pastate (67 pav.), tačiau, nors tai ir primena geometrinę ekspresiją, ji buvo padiktuota daugiau specifinès funkcijos, nei siekio ją hiperbolizuoti. Vienas ryškesnių geometrinès ekspresijos pavyzdžių Lietuvos architektūroje - Nacionalinès dailès galerijos pastatas (archit. G. Baravykas, V. Vielius 1980 m., rekonstrukcija 2009 m., archit. A. Bučas, G. Kuginys ir kt.) (69 pav.), pasižymintis monumentalia, tačiau tuo pačiu ir veržlia architektūrine 
estetika. Ant ilgos vieno aukšto platformos išdėstyti, ritmingai kylantys kubai - pirminès geometrinès formos. Stiklo plokštumos - igilintos, apdaila vieninga, todèl fasado raiškoje dominuoja baltų formų ir šešèlių žaismas. Panašia architektūrine raiška pasižymi ir Kauno paveikslų galerijos pastatas (archit. L. Gelgaudienè, J. Navakas 1978 m.) (69 pav.), KTU dizaino ir technologijų fakulteto auditorijų korpusai (archit. D. Petkelienè 1984 m.) (70 pav.), Anykščiu kultūros rūmai (archit. R. Šileika 1968 m.), parodų rūmai Klaipėdoje (archit. V. ir N. Zubovai $1983 \mathrm{~m}$.).

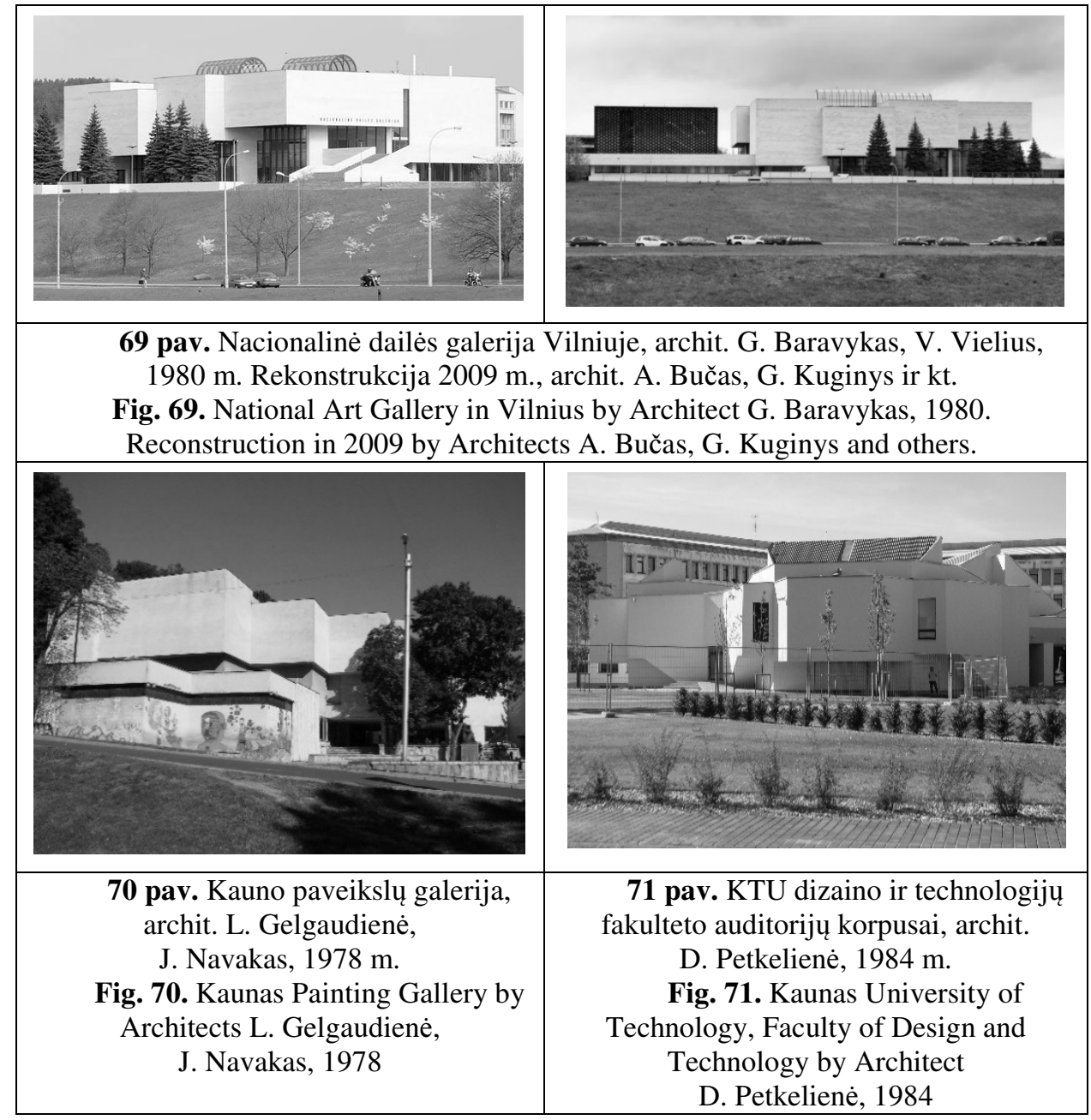

Laužytomis formomis, ekspresyvia planine struktūra ir kompleksiškai sudètingesnemis formomis geometrinę ekspresiją atspindi Ritualinių paslaugų rūmų komplekso Vilniuje, pirmasis korpusas (archit. Č. Mazūras 1975-1987 m.) 
(72 pav.). Smailūs geometriniai pastato tūriai dominuoja pastato meninèje raiškoje ir formuoja pozityvo ir negatyvo konfliktą. Medinių dailylenčių apdaila užbaigiama langų juosta, pabrěžiančia geometrinių formų ekspresyvumą ir dominuojanti pastato charakteri gamtinèje aplinkoje. Planinè struktūra išlieka funkcionali, nors ir sudètingesnè nei iprasta modernistinei architektūrai. Sudètingesne planine struktūra pasižymi ir Litexpo parodų centras Vilniuje (archit. E. Stasiulis 1980 m.) (73 pav.). Čia geometrinè ekspresija igauna struktūralistinių bruožų, yra praturtinama papildomomis medžiagomis (naudojamas aliuminis, terazito ir granito tinkas (Drèmaitè, et. al. 2012)).

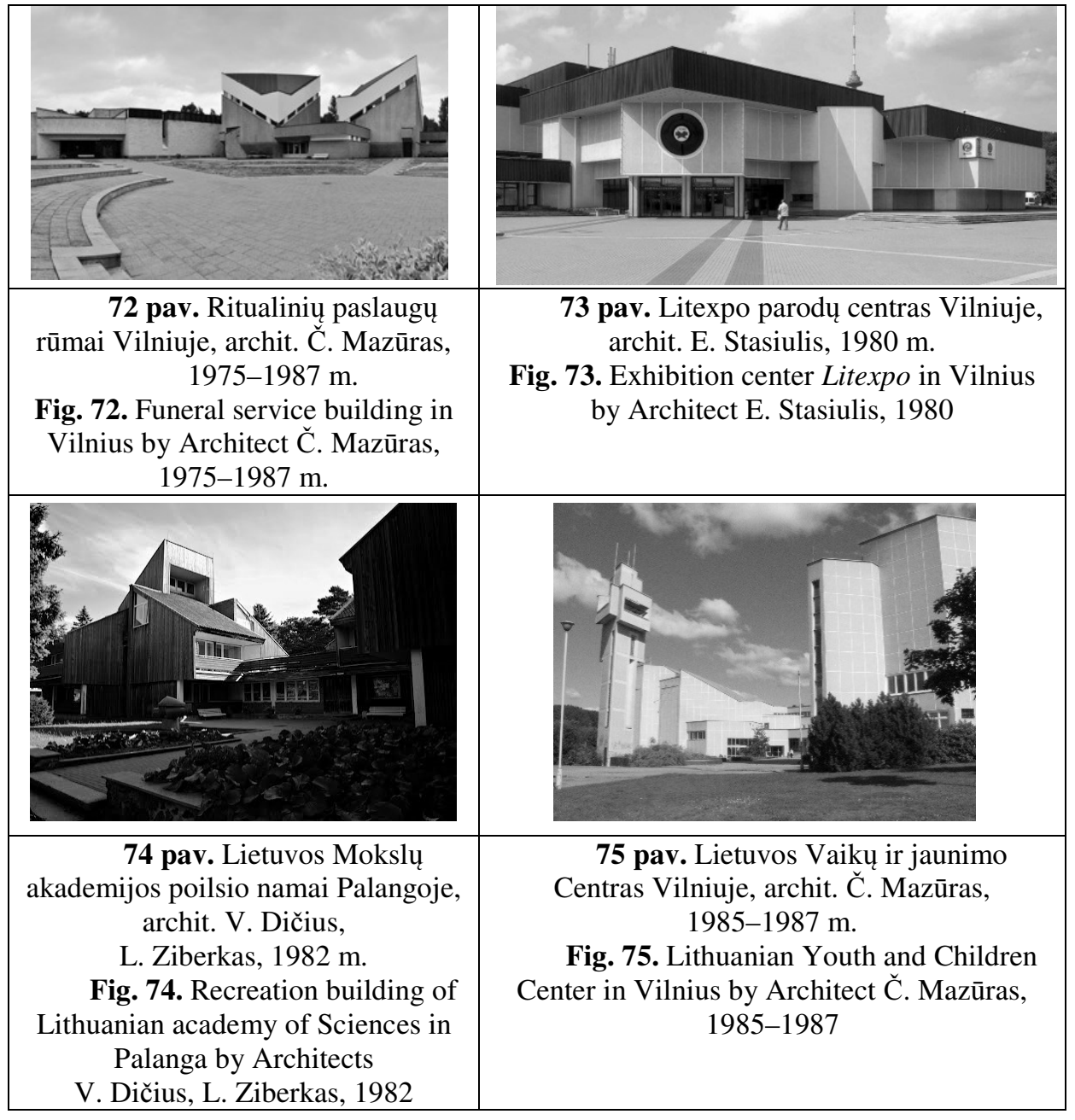

Savita geometrinès ekspresijos apraiškos forma galima laikyti Lietuvos mokslų akademijos poilsio namus (dab. „Pilkasis Garnys“) Palangoje (archit. 
V. Dičius, L. Ziberkas 1982 m.) (74 pav.). Racionalaus išplanavimo kompleksas išsidèstęs kurortinio miestelio aplinkoje. Funkcinè pastato sąranga hiperbolizuota panaudojant ịvairių formų trapecijų tūrius, sukuriant daugiaplanišką monumentalių formų skulptūrą. Artikuliuoti tūriai akivaizdžiai prieštarauja nuosaikiai planinei koncepcijai, daugybè susikirtimų formuoja intrigą ir kuria ekspresyvią ir žaismingą pastato meninę raišką.

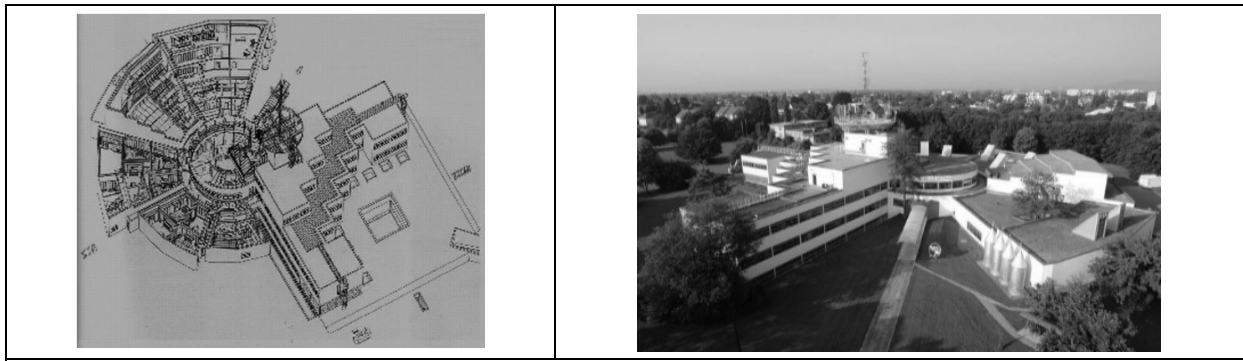

76 pav. Austrijos radijo ir televizijos pastatas Vienoje, archit. G. Peichl 1970-1972 m.

Fig. 76. Austrian Radio and Television Broadcasting building in Vienna by Architect G. Peichl, 1970-1972
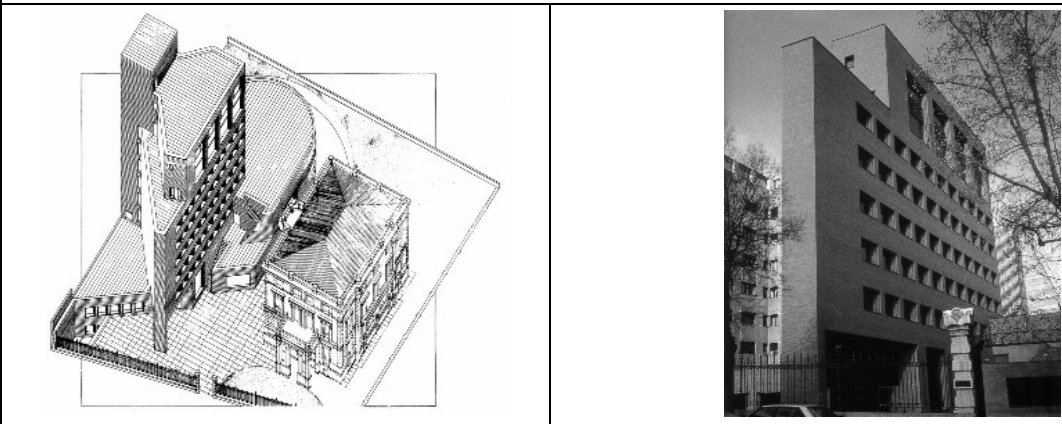

77 pav. Biuru pastatas Madride, Ispanijoje, archit. R. Moneo, 1973-1976 m. Fig. 77. Office building in Madrid, Spain by Architect R. Moneo, 1973-1976

Stiprejant postmodernizmo tendencijoms Lietuvos architektūroje, geometrinis ekspresyvumas buvo pildomas dekoratyviomis formomis, kuriančiomis daugiasluoksnišką ${ }^{5}$ (Jencks 1982) architektūrą. Tarp tokių objektų: prekybos centras „Šeškine““ Vilniuje (archit. G. Baravykas, G. Ramunis, K. Pempè 1978-1985 m.), Vaikų ir jaunimo centras Vilniuje (archit. Č. Mazūras 1985-1987 m.) (75 pav.), poilsinè „Žuvèdra“ (archit. J. Anuškevičius 19741978 m.), oro uosto viešbutis „Skrydis“ (archit. J. Anuškevičius ir kt. 19741978 m.), poilsinè Trakų raj. (archit K. Pempè 1974-1980 m.) ir kt.

${ }^{5}$ Multi - layered (angl.) 
Geometrinių formu ekspresija geriausiai atsiskleidžia, kuomet pastato architektūrinejje raiškoje atsiranda priešingu formų sankirtos, arba formų priešprieša $^{6}$ (Jencks 1982). Tokio pobūdžio geometrinių formų ekspresija gali pasireikšti tiek tūrinejje, tiek planinèje struktūroje. Tikslas - išryškinti pirminių formų skirtumus, arba išskirti ir akcentuoti vieną iš susikertančių formų. Pavyzdžiui, Austrijos radijo ir televizijos pastato (archit. G. Peichl 1970-1972 m.) (75 pav.) struktūroje plastiškų ir statmenų formų susikirtimas simbolizuoja skirtingas pastato funkcijas. Tarnybinès patalpos išdèstytos statǐskame, stačiakampių gretasienių formos korpuse, studijos - plastiškose ir ekspresyviose. Formų susikirtimo taškas - aukščiausia pastato vieta, energetinis centras (Tzionis 1992). Siekiu išryškinti geometrinę formą pasižymi biurų pastatas Madride, Ispanijoje (archit. R. Moneo 1973-1976 m.) (77 pav.). Skulptūriškos formos pjedestalas paryškina geometrinès formos pastato tūrį, kuris atkartoja aplinkinio užstatymo charakterị (Tzionis 1992).

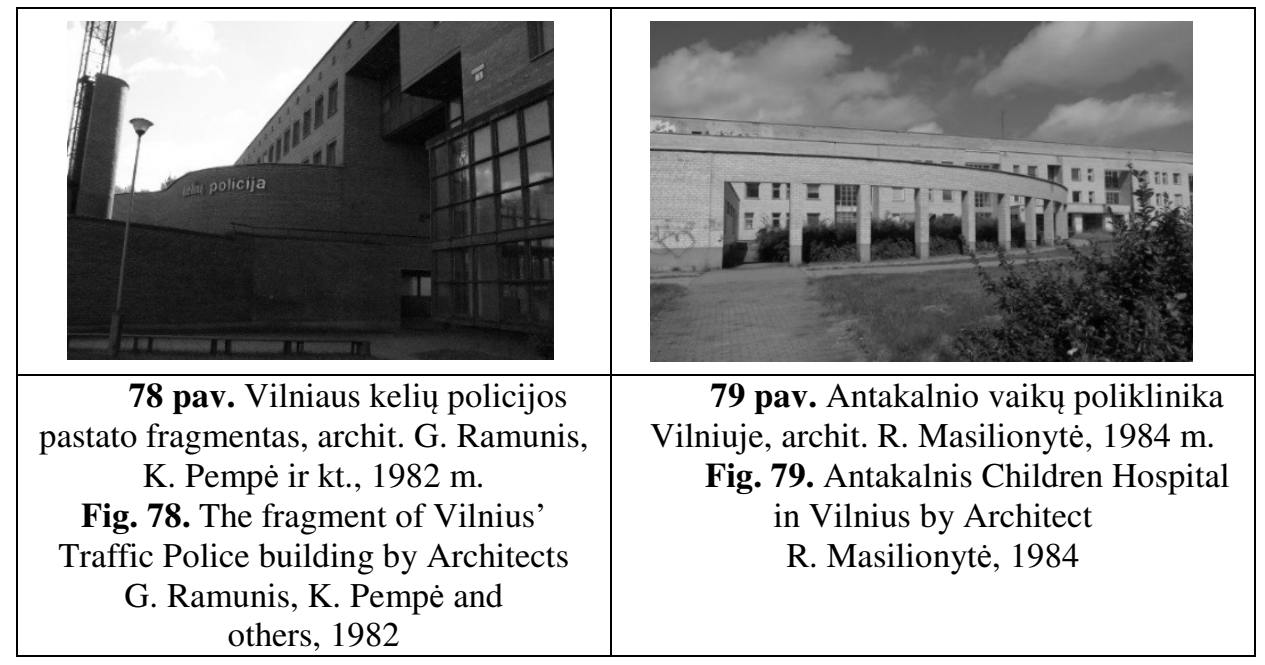

Vienas išraiškingesnių tokio pobūdžio geometrinès ekspresijos pavyzdžiu Lietuvos architektūroje yra Vilniaus kelių policijos pastatas (archit. G. Ramunis, K. Pempe ir kt. 1982 m.) (78 pav.). Nuosaikiai i esamą reljefą ịkomponuotas plastiškas salès korpusas pabrèžia administracinio korpuso geometriškumą, kuris yra dar labiau sustiprintas artikuliuotu langu ritmu. Pastate galima ižvelgti vèlyvojo modernizmo bruožų - tai mastelinio tinklo naudojimas, kuriantis racionalumo îspūdị ir postmodernizmo bruožų - tūrio laiptavimas, turintis simbolistinių užuominų. Kiti formų priešprieša pasižymintys pastatai: Antakalnio vaikų poliklinika Vilniuje (archit. R. Masilionyte 1984 m.) (79 pav.), Pylimo

${ }^{6}$ Juxtaposition (angl.) 
poliklinika, Vilniuje (archit. V. Treinys 1982 m.), parduotuvè „Rèda“ Kaune (archit E. Miliūnas 1984 m.) ir kt.

Pasikartojančių formų ritmika pastato meninèje raiškoje, vèlyvojo modernizmo laikotarpiu, sietina su struktūralizmo tendencijomis pasaulinèje architektūroje, taip pat su artikuliuota geometrinių formų raiška, ir dažnai erdvinès ir/arba konstruktyvinès sąrangos hiperbolizacija (Garcia 2009). Klasikinis struktūralizmo pavyzdys - administracinis draudimo bendrovès pastatas Apeldorne, Olandijoje (archit. H. Hertzberger 1972 m.) pasižymi artikuliuotomis geometrinèmis formomis - kubais, kurie sklype išdèstomi tinklo principu (Frampton 2007). Nuosaikus augimas sklypo gilumos link akcentuoja dinamišką pastato meninę raišką, ,atvirą", nebaigtą formą. Siekiant sustiprinti pabrèžtas geometrines formas, tarp jų paliekami tarpai, taip net nesistengiama pastato sujungti, net interjeruose išskirtinai pabrěžta funkcinè - erdvinè sąranga hiperbolizuoja vidinio išplanavimo principus (80 pav.). Panašiu būdu, tačiau apjungiant atskirus segmentus suprojektuotas ir Vredenburgo muzikos centras Utrechte, Olandijoje (1979 m.). Struktūralistineje architektūroje apskritai, stilistika išreiškiama daugiau tūriniais planiniais sprendimais, ìvairiomis projektavimo sistemomis ir principais.

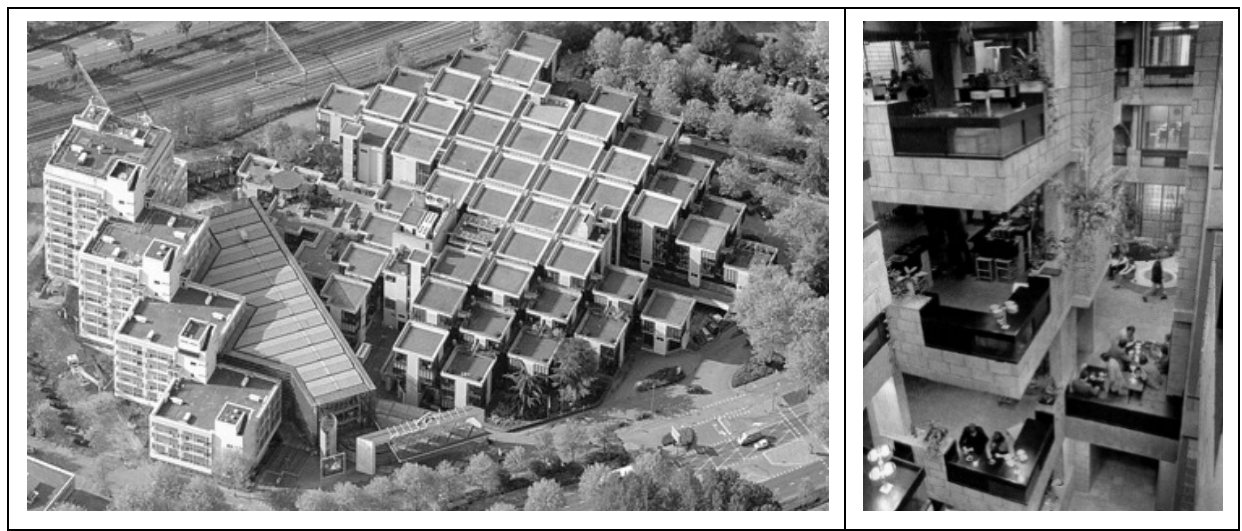

80 pav. Administracinis draudimo bendrovès pastatas Apeldoorn, Olandijoje, archit. H. Hertzberger, $1972 \mathrm{~m}$.

Fig. 80. Administration building of an insurance company in Apeldoorn, Holland by Architect H. Hertzberger, 1972

Lietuvoje struktūralistinei architektūrai plètotis buvo palanki terpè dèl politinès situacijos ir tuo metu vyravusių statybos tendencijų. Moduliai, sekcijos, tipiniai segmentai - visa tai yra labai priimtina struktūralistinei filosofijai. Tokia modulinių geometrinių formų estetika aptinkama gèlių parduotuvès Vilniuje tūriniame sprendime (archit. N. M. Vaičiūnienè 1968 m.). Architekto Algimanto Lècko suprojektuotas pensionas „Žilvinèlis“ Palangoje (1970 m.) (81 pav.), pasižymi trijų sluoksnių kompoziciniu tinklu, kuriame skirtinguose lygiuose 
išdèstomi moduliai. Statinio konstrukcinis sprendimas (baltas gelžbetonio karkasas ir raudonų plytų mūras) matomas fasaduose, kadangi papildoma apdaila nenaudojama. Tokiu būdu pabrèžiamas konstrukcijos dualumas, o tuo pačiu ir pastato kontekstualumas. Išryškintas karkasas turi sąsajų su pajūrio kraštui būdinga fachverko architektūra (Nekrošius 2008). Panašia stilistine raiška pasižymi ir architekto R. Buivydo suprojektuoti poilsio namai „Guboja“, Šventojoje (1976 m.) (Buivydas 2006). Šiuo atveju atviros konstrukcijos išryškinimas tarnauja pagrindinès pastato koncepcijos - vejų išsklaidytų kopu ispūdžiui sustiprinti (82 pav.).

Meninès raiškos skirtumai tarp struktūralistinių Lietuvos ir užsienio architektūros objektų, pasireiškẻ neužbaigtų, tęstinų struktūrų projektavime. Konstrukciškai igyvendinamoje, tačiau sudetingoje, R. Buivydo siūlomoje vadinti „erdvinių blokų“ (Buivydas 2006b) koncepcijoje lietuviškų pavyzdžių atrasti sudètinga. Suprantama, tai itakojo šios koncepcijos specifika, ypatingas reprezentatyvumas, statybos kaštai. Struktūralizmas apsiribojo atvirų formų kūrimu, deja, japonų metabolistų ateities architektūros paieškų nepasiekè. L. Nekrošius teigia, jog struktūralistines užsienio architektūros tendencijas Lietuvos architektai suvokè daugiau fragmentiškai ir formaliai (Nekrošius 2008). Kiti struktūralizmo pavyzdžiai Lietuvos architektūroje: Vilniaus kolegijos pastatas (archit. V. A. Vielius 1985 m.), buitinio aptarnavimo centras Klaipėdoje (archit. E. Arkušauskas 1977 m.), Klaipėdos santuokų rūmai (archit. V. Kranauskas 1979 m.), Litexpo parodų rūmai Vilniuje (archit. E. Stasiulis 1980 m.), irklavimo bazė Trakuose (archit. M. N. Milčiūnienė 1972 m.) ir kt.

\begin{tabular}{|c|c|}
\hline & \\
\hline
\end{tabular}




\subsection{Pirmojo skyriaus apibendrinimai}

1. XX a. antrojoje pusejje Lietuvos funkcionalioji architektūra pasireiškè tarptautiniu stiliumi dèl šios krypties meninès raiškos atitikimo politinèms nuostatoms, dèl socialinių pokyčių (ypatingai dèl gyvenamojo būsto ir kitų svarbių objektų trūkumo), taip pat dèl lengvai pritaikomų konstrukcinių sprendimų skirtingoms vietovès charakteristikoms, unifikuotos statybos. $\breve{S i}$ architektūros kryptis suteike menines ir technines priemones ịvairioms urbanistinèms koncepcijoms, kurios, Lietuvos architektų dèka, tapo išskirtinès meninès vertès gyvenamaisiais rajonais. Ivvairios paskirties kompleksuose matomas tarptautinis stilius Lietuvoje mažai kuo skyrèsi nuo pasaulinio, kadangi rèmèsi panašiomis meninès raiškos priemonèmis. Tarptautinio stiliaus krizė pastebima funkcionaliai formai aplikuojant dekoratyvius, vėlyvajam modernizmui būdingus skulptūrinius elementus.

2. Regioninio charakterio paieškos Lietuvos architektūroje sietinos su dèkingai susiklosčiusiomis politinėmis aplinkybėmis. Po Lietuvos architektų apsilankymų Suomijoje, pradedama jausti šios šalies moderniosios architektūros itaka. V. E. Čekanausko darbuose matomas dèmesys vietinèms medžiagoms, kontekstui, skiriama daugiau dèmesio ịdomesnių formų ir tūrinių kompozicijų paieškai. Netrukus ši tendencija išryškejja ir kitų architektų darbuose, masinejje statyboje (Alytaus ekperimentinių namų statyba). Regioninio savitumo paieškos moderniojoje Lietuvos architektūroje reiškèsi plačiame spektre objektų - nuo gyvenamujų iki sporto kompleksų, visuomeninių pastatų, ligoninių ir mokyklų. Greta kritinio regionalizmo ryški tautinès architektūros linija, apimanti pajūrio kurortų, provincijos miestų architektūrą.

3. Vèlyvasis modernizmas Lietuvos architektūroje ryškiausiai identifikuojamas reprezentacinių objektu, poilsio ir sporto kompleksų statyboje. Geometrinių ir plastinių formų brutalistinè estetika, patraukli masyviomis, monumentaliomis formomis tapo dominuojančia kryptimi Lietuvoje 8-ajame dešimtmetyje. Skulptūrinè plastika palaipsniui dekoratyvejo, peraugo i manieringą, aplikacinį fasadiškumą, kurio pikas buvo pasiektas A. ir R. Šilinskams projektuojant gydyklų ir sanatorijų kompleksus Druskininkuose.

Vèlyvojo modernizmo geometrinių formų ekspresija išliko viena dominuojančių meninès raiškos krypčių iki pat 1990-ųų, vietomis pasižymèjusi struktūralistinei architektūrai būdingais bruožais, kitais atvejais - adaptavusi dekoratyvias postmodernistines formas. 


\section{2}

\section{Pasaulinių stilistinių tendenciju raiška šiuolaikinëje Lietuvos architektūroje (1990-2013 m.)}

Nagrinèjant šio prieštaringo dvidešimtmečio architektūros meninès raiškos raidą, reikia turèti omenyje pagrindini skirtumą nuo prieš tai buvusio keturių dešimtmečių laikotarpio. Visų pirma, tai pasikeitusios sociokultūrinès ir politinès aplinkybès. Privatus užsakovas pakeitè valstybinius užsakymus, to pasekoje suiro didžiujų projektavimo institutų struktūra. Tai atvėrè galimybes naujų medžiagų naudojimui, įsitvirtino kompleksiška postmodernizmo meninè raiška ir paplito techninè estetika. Šiek tiek sistemingumo bandant aprèpti bendrą sociokultūrinị kontekstą suteikia R. Buivydas, pirmaji nepriklausomos Lietuvos architektūros dvidešimtmetị skirstydamas ị tris raidos etapus. Pirmajame etape gausu pozityvių ir negatyvių procesų: gausybé entuziazmo, idealizmo, drąsos persipynusios su chaotiškumu ir skubotumu, dažnai sąlygotu konkurencijos ir pačio architektūros cecho pajègu ribotumo, teisinių reglamentų nebūvimo. Antrasis etapas sistemingesnis, pradèjo veikti teritorijų bendrieji ir specialieji planai, statybos reglamentai, pakilo bendra tiek rangovų, tiek projektuotojų tiek statytojų kompetencija. Išaugo statybos technologijų našumas. Šiame etape R. Buivydas išskiria ir kelis neigiamus aspektus: nepamatuotas taupymas, nekorektiška konkurencija, teisinių reikalavimų nepaisymas. Trečiajame etape pastebimas 
lietuviškos architektūros nuosaikumas ir kryptingumas, siekis ịtvirtinti architektūrą aukštesniu nei utilitariu lygmeniu. Pavyzdžiui, parengtas dokumentas „Lietuvos Respublikos architektūros politikos kryptys“, ieškoma glaudesnių ryšių su visuomene įtraukiant ją i judejjimus, diskusijas, forumus, etc. (Buivydas 2012).

Tomas Grunskis taip pat pastebi tam tikrą sociokultūinị, politini etapiškumą aptariamu laikotarpiu. Pirmasis etapas - sociokultūrinis lūžis 1990-aisiais, kurio ženklai pastebimi beveik visą dešimtmeti. Šiuo laikotarpiu ryškus postmodernistinis chaosas, kurio metu laisvesnès kūrybinès galimybès pralenkè ekonomines. Prie to prisidèjo ir menkas užsakovų architektūrinis išprusimas, todèl dažnai realizacijos buvo konservatyvios, laiko patikrintos, lengvai suvokiamos. Antrasis etapas sąlygotas Rusijos ekonominès krizès 1998-aisiais. Šiuo sudètingu nuosmukio laikotarpiu pelninga architektūrinè veikla sustojo, ko pasekoje atsirado kūrybiškesnès ir tuo pačiu laisvesnès architektūros. Trečiasis etapas daugiau susijęs su Lietuvos integracija i Europos ir Euroatlantines struktūras, suteikusias ženklius ekonominius postūmius. Šis laikotarpis žymi administracinius korporacijų pastatus dešiniajame Neries krante Vilniuje, prekybos centrų atsiradimą, komercinių objektų bumą, iškejlusį vertybinius ir kūrejjo profesinès etikos klausimus (Grunskis 2012). Žymūs nagrinejjamo laikotarpio architektai mini ir kitus socialinius faktorius, lėmusius šio laikotarpio išskirtinumą. Svarbios naujos projektavimo priemonès prie kurių reikejjo prisitaikyti, tačiau jos atvèrè ir dideles galimybes, privati rinka ir spartūs tempai sąlygoti konkurencijos, architekto-verslininko, o ne menininko ịvaizdis, pasikeitusi teisinè aplinka, viešieji pirkimai, pakeitę architektūrinių konkursų specifiką bei chaotiška urbanistinè plètra ir kt. (Grunskis, et al. 2012).

Architektūrinių stilių požiūriu, pirmasis nepriklausomos Lietuvos architektūros dešimtmetis gali būti laikomas postmodernistiniu, tačiau toje postmodernistinejje meninejje raiškoje dominuoja socialiniai, o ne idèjiniai faktoriai. K. Lupeikis teigia: „Postmodernistinès architektūros prabangią išraišką lèmé priemonių gausa, kuri tiek medžiagų, tiek naujų technologijų, tiek informacijos pavidalu i Lietuvą ypač aktyviai pradejo skverbtis paskutinio dešimtmečio viduryje“" (Lupeikis 2002). Tokią, kiek chaotišką situaciją ir paviršutinišką situacijos suvokimą konkrečiau paaiškina K. Gerliakas: „Ch. Jenckso knyga ${ }^{7}<\ldots>$ Lietuvos architektams , padejjo“ suformuoti ịvaizdį, kas yra postmodernistiné architektūra. Šis ịvaizdis pagrịstas ne ịsigilinimu ị Ch. Jenckso tekstus ir mintis, o i vizualinę iliustracinę medžiagą. Lietuvoje isivyravo vulgarizuotas postmodernizmo supratimas. Manoma, kad jei pasitelki istorines detales (pvz.: piramides, kolonas) tai jau turi kontekstualu projektą ir esi postmodernistas“" (Gerliakas 1996). Vedamas formalių stiliaus principu postmodernizmas ypatingai paplito individualių gyvenamuju namų

${ }^{7}$ Charles Jencks - The Language of Post-Modernism 
architektūroje, pavojingai balansuodamas ties kičo riba. „Kičo apraiškas <...> miesto archdizaine galima sieti su postmodernizmu, kuris propaguoja eklektizmą, orientuoja i istorizmo retrospekciją, regionalizmą - „kaimiškąsias“ formas“ (Mačiulis 2008). Eklektiškai derinami istoriniai ir tautiniai motyvai, hiperbolizuoti architektūriniai elementai atspindèdavo užsakovo užmojus ir finansines galimybes. Lietuvos kraštovaizdyje galima aptikti tiek „XIX a. angliško stiliaus namą, tiek Kalifornietišką amerikiečių vasarnamį“ (Mačiulis 1996). Postmodernizmo stiliaus apraiškas Lietuvos architektūroje ịtakojo vakarietiški architektūros leidiniai, o ne savaiminis stiliaus vystymasis, užsakovo norai ir rinkos sąlygos, o ne architekto sumanymai.

Kaip vienas iš svarbesnių šiuolaikinès architektūros ženklų minimas ir dešinysis Nėries krantas Vilniuje, architektūros tyrinètojų nagrinejjamas tiek urbanistiniu, vizualiniu, tiek menotyriniu aspektais (Vyšniūnas, et. al. 2004), (Grunskis 2005), (Daunora 2003). Tai tarsi naujojo Vilniaus simbolis kuriame aukštuminiai verslo korporacijų pastatai atskleidžia techninei estetikai būdingą metalo konstrukcijų ir spindinčių paviršių architektūrinę raišką. Šią, vèlyvajam modernizmui būdingą architektūros krypti Lietuvoje ịtvirtino su anksčiau aptartais ekonominiais procesais sietinas prekybos ir administracinių kompleksu poreikis, formuodamas ištisų kvartalų užstatymą. Techninei estetikai būdinga high-tech ir slick-tech meninè raiška pradejo dominuoti autosalonų, poilsio kompleksų, gyvenamujjų namų, visuomeninių objektų architektūroje.

Śiame skuriuje apžvelgiama skirtingų architektūros krypčių ir stilių meninès raiškos ịvairové šiuolaikinèje Lietuvos architektūroje, nustatomi jų raiškos bruožai, savitumai, paplitimas, sąsajos su pasaulinemis tendencijomis ir naujais architektūrinès formos kūrimo principais. Nagrinejama problematika yra aptarta autoriaus publikacijose (Mačiulis 2010, 2012, Lupeikis, Mačiulis 2011)

\subsection{Techninè estetika ir paviršių raiška}

Hiperbolizuotų, pasaulinès architektūros vèlyvojo modernizmo formų kontekste, galima ižvvelgti architektų siekị grąžinti funkcionalią, technologijomis ir konstrukciniais principais paremtą architektūrinę raišką. Kritinis regionalizmas rèmèsi tarptautinio stiliaus diktuojamais projektavimo principais, tačiau reprezentavo vietinès architektūros tradicijas. Skulptūriškas ir ekspresyus vèlyvasis modernizmas reprezentavo priešingą siekį - išsilaisvinti iš monotoniškos funkcionalistinès meninès raiškos. Techninė estetika funkcionalumą ir konstruktyvą hiperbolizuoja iki tokio lygmens, jog struktūra tampa ornamentu.

Nagrinejjant techninès estetikos high-tech ir slick-tech architektūrą Lietuvoje, lyginti šių krypčių raiškos bruožus su užsienio pavyzdžiais tiesiogiai, nèra 
tikslinga, o ir neinformatyvu. Šios architektūros kryptys Lietuvoje pradèjo reikštis tik nepriklausomybès laikotarpiu, taigi gerokai vèliau nei užsienio architektūroje. Ivertinant technologijų įtaką high-tech ir slick-tech architektūrai, turint omenyje spartų jų vystymąsi, šių krypčių paplitimą Lietuvoje ir užsienyje tikslinga nagrinèti atskirai, siekiant apibrèžti meninès raiškos principus ir savitumus, o ne ieškoti meninès raiškos bendrumų. Juolab, jog pirminiai techninès estetikos bruožai (pavyzdžiui, tiesioginis konstrukcinių ir inžinerinių sistemų iškèlimas i išorę, artikuliuotas pastato konstrukcinès sąrangos eksponavimas) pasiekę Lietuvos architektūrą jau buvo laikomi atgyvenusiais, todèl nebuvo tiesiogiai taikomi.

Techninès estetikos sąvoka ir meninès raiškos bruožai. Vèlyvojo modernizmo techninę estetiką užsienio architektūros tyrinètojai sieja su prieš tai buvusiais stiliais. A. Tzonis ir L. Lefaivre (Tzionis 1992), techninès estetikos sąvoką apibūdina naujuoju rigorizmu (angl. Neo-rigorism), remdamiesi rigorizmo terminu, kuris reiškia „tik tai, kas reprezentuoja funkciją“ (terminas buvo taikomas apibūdinti klasicistinę architektūrą baroko kontekste dar XVIII a. viduryje). K. Frampton techninę estetiką įtraukia i produktyvizmo terminą, siedamas ją su L. Mies van der Rohe dangoraižiais (Frampton 2007). R. Banham (Banham 2008) ir Ch. Jencks tai vadina antraja technine estetika (pirmaja technine estetika laikoma moderniosios architektūros tarptautino stiliaus raiška).

Techninès estetikos meninių priemonių raišką galima sieti su vèlyvojo modernizmo hiperbolizacijos tendencijomis pasaulinèje architektūroje. Ch. Jencks teigia (Jencks 1990), jog techninè estetika architektūroje pradèjo reikštis siekiant struktūrinę pastato sąrangą traktuoti kaip ornamentą, ir išskyrè pagrindinius techninès estetikos architektūrinès raiškos bruožus:

- lankstumas, kitimas, judesys;

- jautrumas, reakcija ị aplinką;

- ivvairūs konstruktyviniai elementai.

Tiek Ch. Jencks, tiek A. Tzonis ir L. Lefaivre vèlyvojo modernizmo techninès estetikos pagrindinị bruožą ịvardina dinamišką, atvirą ir kintančią formą, tuo besiskiriančią nuo pirmosios techninès estetikos. Tokią tūrinę dinamiką galima pasiekti dèl surinkimui naudojamų lengvų konstrukcijų, kurios, dèl kompiuterizuotų gamybos metodų nèra standartizuotos, o gaminamos unifikuotai, vèliau surenkamos kaip skeletas, pastarasis po to dengiamas pageidaujama medžiaga. Techninè estetika suteikè galimybę Archigram sukurti ,vaikščiojančio miesto“ koncepciją (archit. R. Herron 1964 m.) (Cook 1999), kurią galima palyginti su panašių tikslų siekusių futuristų statiškais urbanistiniais bandymais, pavyzdžiui A. Sant‘Elia „La Città Nuova“ (1914 m.).

Laikotarpio dvasią atspindinti techninė estetika davė impulsą high-tech architektūrinès krypties atsiradimui. Architektūros tyrinètojas Colin Davies teigia, jog high-tech architektūra gali būti laikoma pilnaverte architektūros kryptimi, nes 
yra pagrindžiama idejjomis, o tuo pačiu išsiskiria ir meninès raiškos priemonèmis bei unikaliais konstrukciniais sprendimais toms idejoms perteikti (Davies 1988). High-tech nèra tik statybos principas ar pastato vaizdą kurianti išraiškos priemonè. High-tech ịūnija laikmečio dvasią, kuri atsispindi aukštujuc technologiju issisavinimu ir dominavimu tiek gamybos, tiek surinkimo, tiek architektūrinès raiškos prasme. Pasak autoriaus, high-tech architektūra tiesiogiai įkūnija modernistų siekį paversti namą „mašina, kurioje galima gyventi ${ }^{8 “}$. Hightech pastatai ne tik atrodo kaip mechanizmai, jie ir pagaminti iš plastiko, stiklo ir metalo, taigi tai yra daugiau nei metafora, pastatas tampa industrinių technologiju dalimi, kuriame socialiniai ar meniniai faktoriai neturi itakos. High-tech pastate išryškinamas funkcionalumas ir naudingumas, simbolinè ir menine raiška neakcentuojama. C. Davies išskiria pagrindinius high-tech architektūrinès raiškos požymius:

- akcentuotas ir matomas metalinis karkasas;

- nepridengti inžineriniai/konstrukciniai ryšiai;

- lengvi metaliniai, plastikiniai ar stikliniai paneliai.

Tokia ekspresyvia architektūrine raiška siekiama keleto tikslų - struktūrinių pastato elementų eksponavimas atskleidžia funkcinius ryšius, o techniniai pastato elementai yra pagrindiniai meninès raiškos formantai.

Objektai. Užsienio architektūroje lengvų konstrukcijų surenkami pastatai visų pirma paplito pavilijonų, dideliu prekybos, visuomeninių objektų, sporto angarų statyboje. Išskirtinis techninès estetikos pavyzdys - Miuncheno olimpinis kompleksas Vokietijoje (archit. G. Behnisch 1972 m.) (83 pav.). Lengvasvoré konstrukcija tapo prieštara tuo metu dominavusių sunkių konstrukcinių sistemų monumentalumui. Olimpinio komplekso palapinès tapo tiesiog gamtiniu ornamentu, primenančiu laivo bures, skèčius, medžio lapus. Konstruktyvinè hightech architektūros krypties specifika leido vystyti išraiškingesnių, bioninių formų architektūrinę raišką, kuri matoma 9 ir 10 dešimtmetyje. Kansai aerouosto terminalo Japonijoje (archit. R. Piano 1988-1994 m.) pastate (84 pav.), banguojanti, atvira forma primena lèktuvo sparno aerodinamines savybes, iliustruoja oro srautų tèkmę. Traukinių stoties Liono aerouoste, Prancūzijoje (archit. S. Calatrava 1989-1994 m.) korpuse (85 pav.), dominuojantis konstruktyvas sukuria uždarą bioninę formą, primenančią skeletą. İspūdis sustiprinamas lengvų, skaidrių ir masyvių formų santykiu, kuomet ant smulkių atramų tinklo uždedama masyvi stogo konstrukcija. Panašia menine raiška pasižymi R. Rogers projektuoti teismo pastatų kompleksai Bordo mieste Prancūzijoje (1992-1998 m.) ir Antverpene, Belgijoje (1998-2005 m.) (86 pav.), N. Grimshaw projektuoti stočių paviljonai Londone, Anglijoje (1993 ir 1999 m.), ir Melburne, Australijoje (2007 m.).

\footnotetext{
${ }^{8}$ House as a Machine to Live In - Le Corbusier
} 


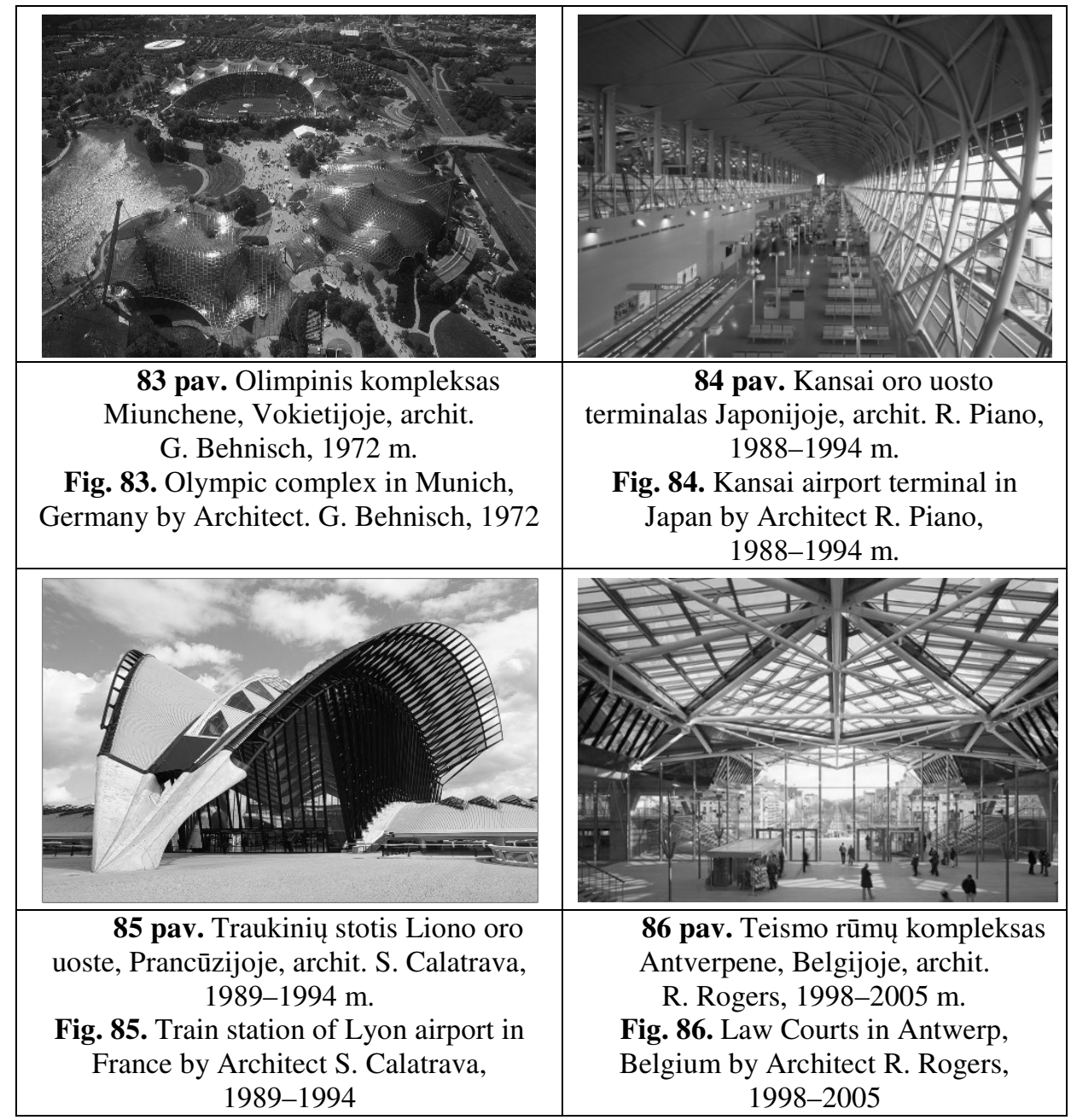

Miuncheno olimpinio komplekso pavyzdys paskatino architektus eksperimentuoti su surenkamomis konstrukcijomis jas standartizuojant. Jeigu olimpinio komplekso statyboje surenkamos konstrukcijos buvo užsakomos ir gaminamos individualiai, o paprastumas atsiskleide statyboje, tai sekantis architektų tikslas buvo standartizuoti gamybinius procesus. Konstrukcijų sistemos surenkamos iš laisvai pasirenkamų detalių galejo būti naudojamos itin plačiai, nuo gamybinių iki gyvenamujų ir net reprezentacinio pobūdžio pastatų. Pavyzdžiui, architekto N. Foster suprojektuotame vizualiujų menų centro architektūrinëje raiškoje Norviče, Anglijoje (1975-1978 m.) (87 pav.) atsiskleidžia surenkamų sistemu panaudojimo galimybès, kuomet skirtingos detalès jungiamos tuo pačiu principu, standartizuotai. Vis dèlto, didžiausias surenkamų konstrukcijų 
potencialas, dèl standartizacijos galimybiu, buvo regimas gyvenamujų namų statyboje (Jackson 1990). Architekto Helmut Schulitz namas Los Andžele, JAV (1976 m.) (88 pav.) ir architekto Michael Hopkins namas Londone, Anglijoje (1978 m.) (89 pav.) pastatyti tokiu pat standartizuotu ir lengvai surenkamų konstrukcijų principu, tačiau iliustruoja skirtingas architektūrinès raiškos galimybes. H. Shulitz namas - tai lengvų konstrukcijų karkasas išsidèstęs šlaite. Čia naudojamos high-tech estetikai būdingos medžiagos - stiklas, profiliuota skarda, metalas. Kai kurios inžinerinès komunikacijos pabrèžiamos nudažant jas kontrastinga spalva. M. Hopkins namas pasižymi dar labiau artikuliuota pastato struktūra. Pastato karkasas uždengtas stiklu, matomi ịtempti trosai, viduje erdves skaidančios santvaros. Panašios stilistikos gyvenamieji namai populiarūs ir XXI a., tačiau šiuolaikinejje architektūroje high-tech estetika naudojama ne siekiant paprastumo, o norint pabrěžti išskirtini pastato charakterị ir užsakovo skonị. Pavyzdžiu galètų būti gyvenamasis namas Štutgarte, Vokietijoje (archit. W. Sobek 2000 m.) (90 pav.).

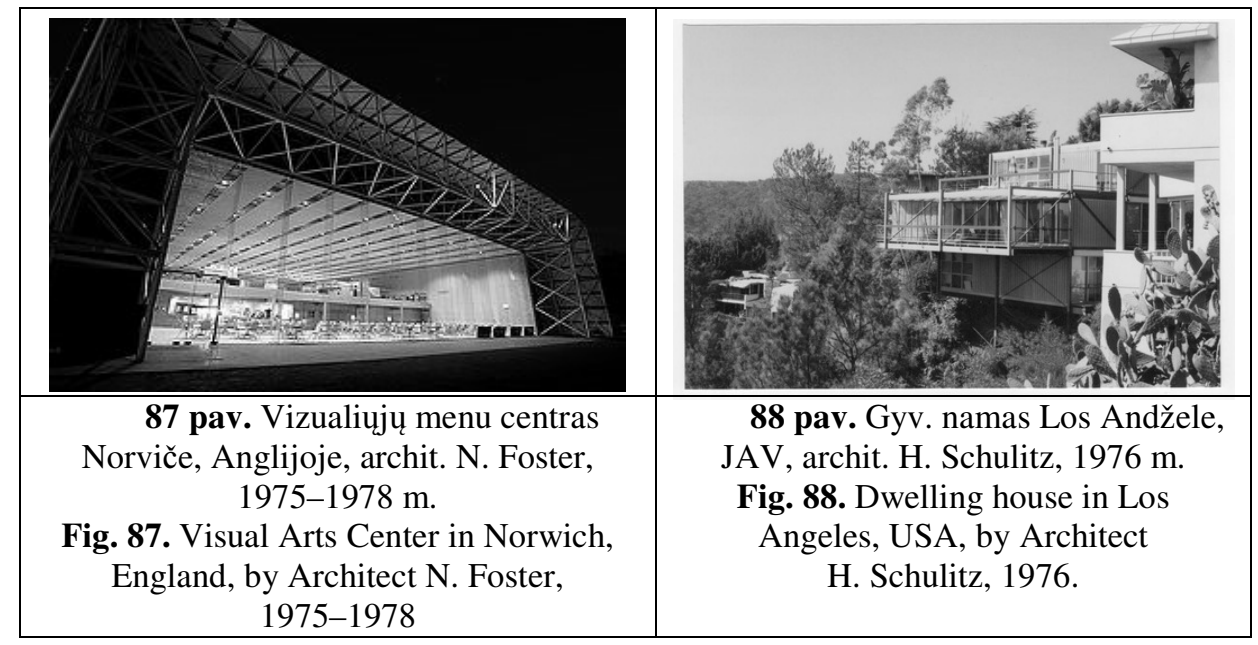

Logiška, pragmatiška surenkamų konstrukcijų techninès estetikos meninė raiška buvo hiperbolizuota Pompidou meno centro pastate Paryžiuje, Prancūzijoje (archit. R. Piano ir R. Rogers 1971-1977 m.) (91 pav.). A. W. Charleson nagrinèdamas struktūros įtaką pastato architektūrinei formai teigia, jog pastato struktūra tiek hiperbolizuojama, jog pradeda dominuoti pastato architektūrinejje raiškoje. Tai galima vadinti struktūrine ekspresija, kuri yra būdinga ir kitiems high-tech pastatams (Charleson 2005). Hiperbolizacija pastebima visuose pastato parametruose - logikoje, technologijoje, judèjimo zonose, komunikacijose, struktūroje ir konstrukcijoje. A. Tzionis ir L. Lefaivre (Tzionis 1992) pastebi, jog šiame pastate galima įžvelgti Rusijos konstruktyvistų, Buckminster Fuller, Yona 
Friedmann, Louis ir Albert Kahn ir Archigram įtakas. Šių idejjų sintezè atspindi ir pastato funkciją - meno centrą.

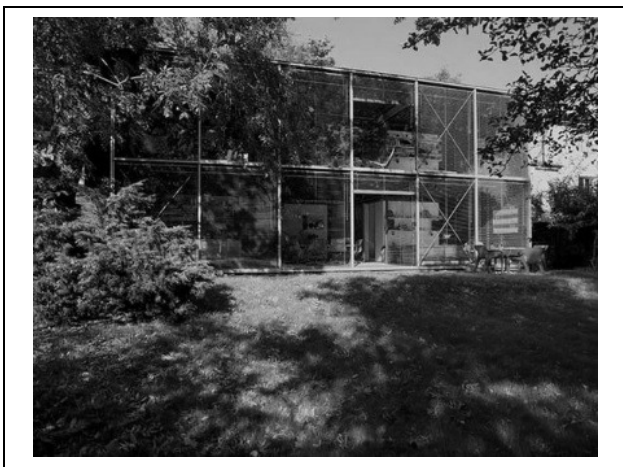

89 pav. Gyv. namas Londone, Anglijoje, archit. M. Hopkins, $1978 \mathrm{~m}$.

Fig. 89. Dwelling house in London, England, by Architect M. Hopkins, 1978.

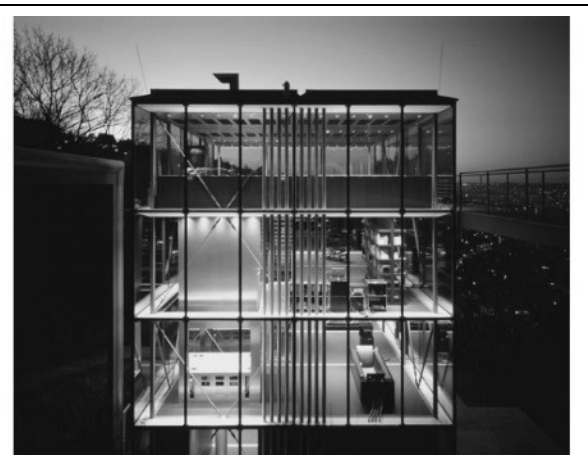

90 pav. Gyv. namas Štutgarte, Vokietijoje, archit. W. Sobek, $2000 \mathrm{~m}$.

Fig. 90. Dwelling house in Stuttgart, Germany, by Architect W. Sobek, 2000.

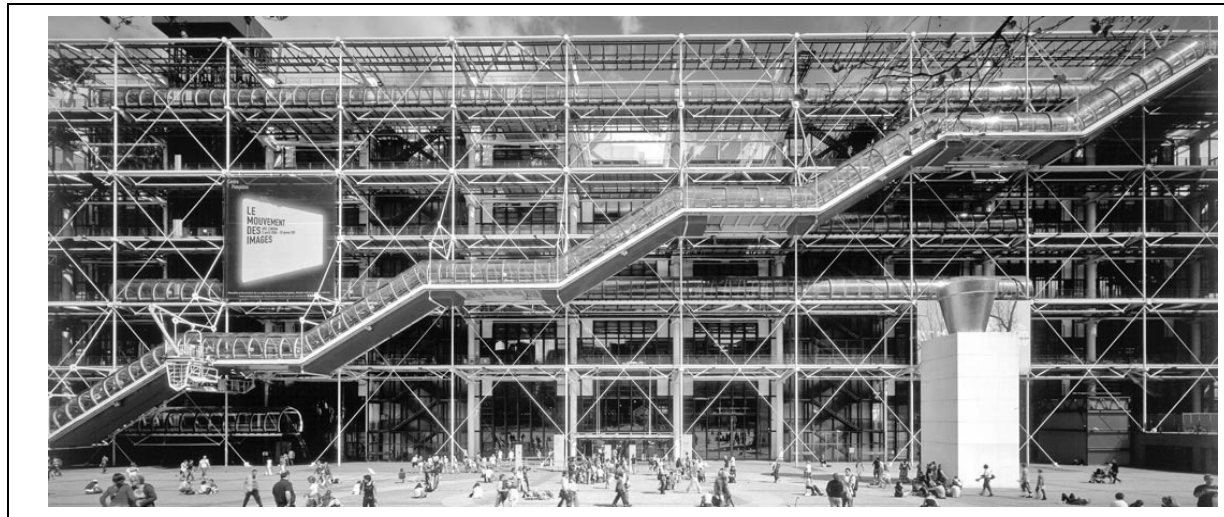

91 pav. Pompidou meno centras Paryžiuje, Prancūzijoje, archit. R. Piano, R. Rogers 1971-1977 m.

Fig. 91. Pompidou Arts Center in Paris, France, by Architects R. Piano and R. Rogers 1971-1977

Pastatas užima pusę jam skirto sklypo, likusi dalis - visuomeninè erdvė nuosaikiai link iejjimo besileidžianti aikštè, formuojanti tarsi amfiteatrą, kuris greitai tapo visuomenès traukos centru. Meno centro funkcinè schema - išskirtinai paprasta, sudalinta ị kelias atskiras zonas. Primojo aukšto holas skirtas bendroms patalpoms iš kurių patenkama i transformuojamu gabaritu ekspozicijų sales, knygyną, kavinę. Viršutiniame aukšte ịrengtos apžvalgos terasos ir restoranas. Vertikalus ir horizontalus žmonių srautų judējimas (išoriniais liftais, viduje), išeksponuota konstrukcinè, inžinerinè schema, leidžianti matyti vidinių erdvių 
transformacijas sukuria gyvo organizmo iliuziją, teigia judejjimą, kuris yra būdingas futuristams ir konstruktyvistams.

Vis dèlto, šis high-tech architektūros bruožas, kuomet struktūriniai elementai ir judejimo srautai nukreipiami i pastato pakraščius, nepasiteisino kitame architekto R. Rogers suprojektuotame pastate - „Lloyd's“" draudimo bendrovès Londone, administraciniame korpuse (1978 - 1986 m.) (92 pav.). Architektui adaptavus Pompidou meno centro projekte naudotą planavimo principą, nebuvo ivertinta skirtinga naujojo pastato paskirtis, o taip pat ir aplinkinè situacija. I pastato išorę iškèlus inžinerines sistemas ir vertikalius judejjimo ryšius, sumažèjo darbo erdvès apšviestumas. Kabinetai, galerijos principu išdèstyti aplink atvirą vidinę erdvę, pasižymèjo dienos šviesos trūkumu, menkomis apžvalgos galimybèmis. Pastatas susilaukè kritikos ne tiek dèl inovatyvios architektūrinès raiškos, o dèl to, jog planuojant patalpas nebuvo įvertinti greta stovintys pastatai. Užsakovų siekiai - atvirumas, erdvių transformavimo galimybès, inovatyvumas, sutapo su R. Rogers kūrybos siekiais ir high-tech architektūros braižu, tačiau „Lloyd"s“ administracinis pastatas tai perteikè tiesiogiai, imituojant judesi ir dinamiką techninès estetikos raiškos priemonèmis, tačiau nereaguojant i patalpų specifiką ir kontekstą (Tzionis 1992).

\begin{tabular}{|c|c|c|}
\hline & \\
\hline
\end{tabular}

Vèlesniuose, ekspresyvia struktūrine raiška pasižyminčiuose administracinès paskirties pastatuose regimi kompromisiniai sprendimai. Išlaikant aukštuminiams 
pastatams būdingą planavimo principą (vertikalūs ryšiai išdèstomi pastato centre, šalia kurių projektuojamos ertmès inžinerinèms komunikacijoms, o aplink išdėstomos administracinès ar komercinès patalpos), pastato išorejje pabrèžiama laikančioji konstrukcija. Pavyzdžiui, administracinis pastatas San Franciske, JAV (archit. L. Skidmore ir kt. 1984 m.), bankas Honkonge, Kinijoje (archit. N. Foster 1986 m.) (93 pav.), viešbutis Barselonoje, Ispanijoje (archit. „SOM“ 1992 m.) (94 pav.) ir kt.

Japonu metabolistų, „Team 10“ utopistų (Team 10 2008) idejjomis ir hightech estetika pasižymintis medicinos tyrimų centras Achene, Vokietijoje (archit. „Weber, Brandt und Partners“ 1968-1986 m.) (95 pav.), vienas labiausiai priartejjusių prie gyvo, kintančio pastato koncepto, kuri stengèsi išplètoti R. Piano ir R. Rogers. 6000 palatų aptarnaujančio tyrimų komplekso erdvinè - funkcinè struktūra primena nedidelius miesto kvartalus. İspūdị sustiprina tarp korpusų, ant stogu įrengtos žaliosios zonos - vidiniai kiemai. Išorejje dominuoja inžinerinių sistemų tinklas, viduje - metalo ir plastiko high-tech estetika (96 pav.). Atvira tinklo plano struktūra leidžia pastatui pastoviai plèstis (paskutinis išplètimas 2011 m.), sukuriant judejjimo ir dinamiškumo metaforą.

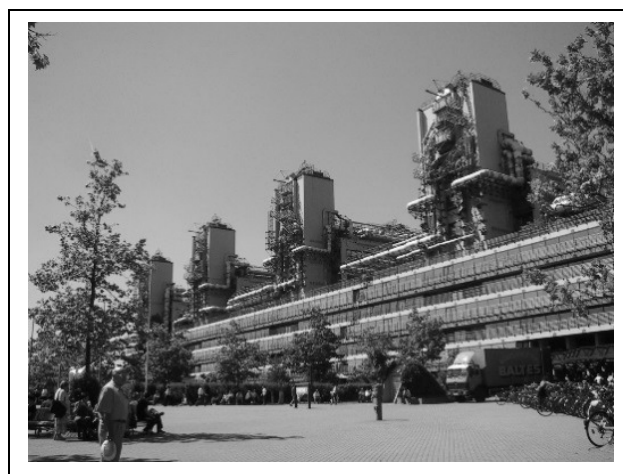

95 pav. Medicinos tyrimų centras Achene, Vokietijoje, archit. Weber, Brandt und Partners, 1968-1986 m.

Fig. 95. Medical Research Center in Aachen, Germany, by Architects Weber, Brandt und Partners, 1968-1986

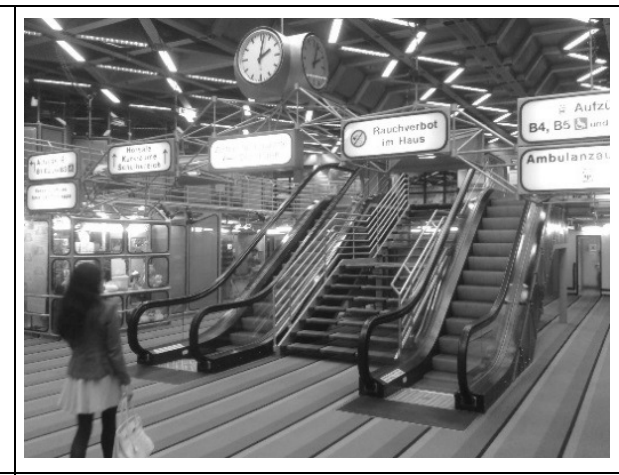

96 pav. Medicinos tyrimų centro Achene, Vokietijoje interjeras, archit. Weber, Brandt und Partners, 1968$1986 \mathrm{~m}$.

Fig. 96. Interior of the Medical Research Center in Aachen, Germany, by Architects Weber, Brandt und Partners, 1968-1986

Savitą požiūrị ị high-tech architektūrą galima pastebèti Japonų architektų K. Kurokawa, F. Maki, A. Isozaki ir kt. kūryboje. Pavyzdžiui, administraciniame pastate Tokijuje, Japonijoje (archit. K. Kurokawa 1982-1984 m.) (97 pav.) konstrukcinè sandara paslèpta už aliuminio panelių apvalkalo, tačiau pabrež̌ta horizontaliu fasado skaidymu. Čia high-tech architektūra suprantama kaip tiesioginè buitinio prietaiso ar mechanizmo interpretacija. Techninę estetiką 
šiame pastate primena detalès. Pusapvalis viršutinis aukštas su žaismingomis langų formomis, apvalus iejjimo stogelis. Pats architektas viršutiniojo aukšto holą apibūdina kaip ,,japoniško stiliaus kosminị laivą“ (Mallgrave 2011) (98 pav.).

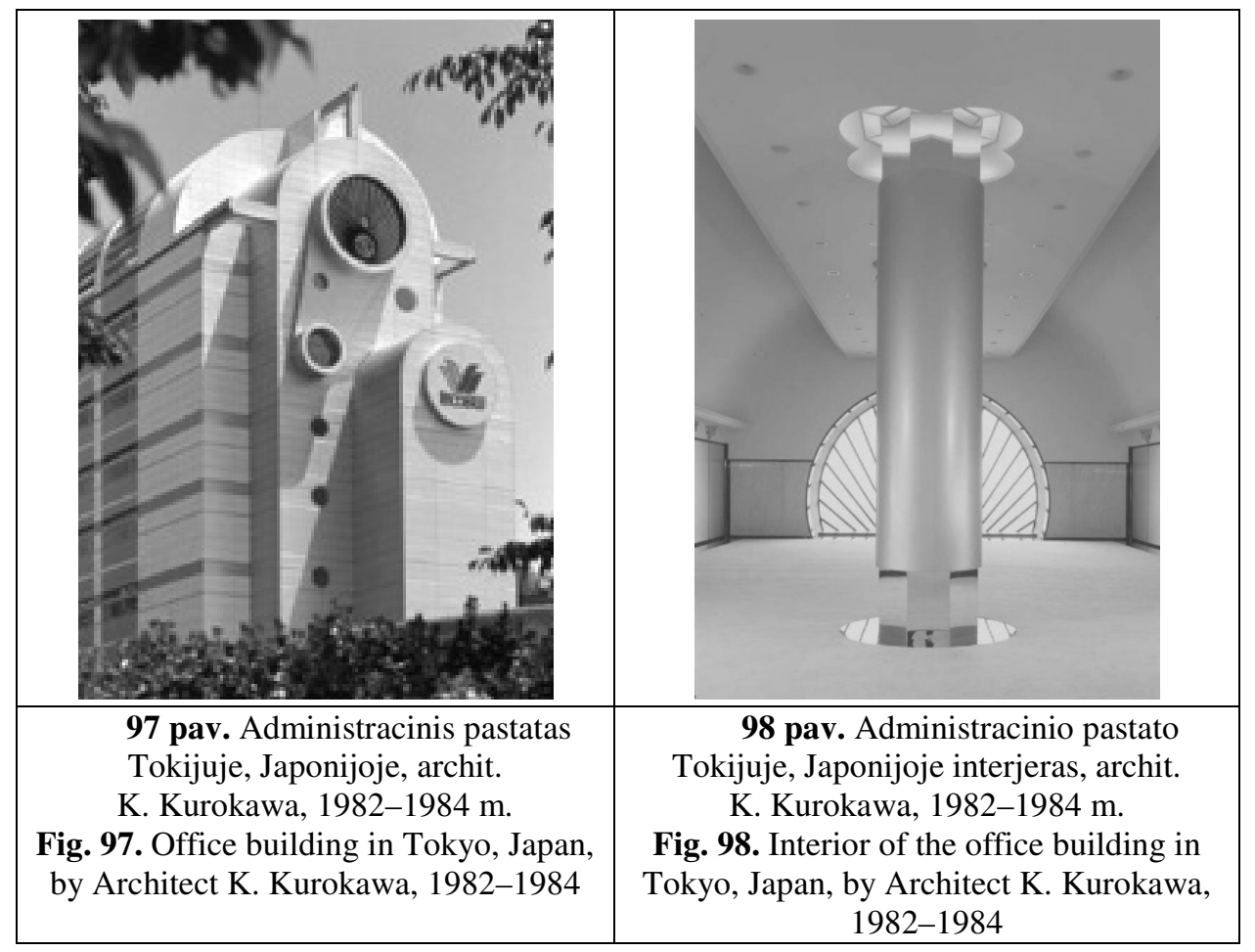

Pirmieji High-tech meninès raiškos bruožai Lietuvos architektūroje pastebimi devintojo dešimtmečio pradžioje, pavieniuose architektūriniuose elementuose. Vytauto Brédikio, Vladislavo Mikučianio ir Vytauto Nasvyčio suprojektuotų Vilniaus Dailès akademijos naujujų rūmų korpuse $(1981 \mathrm{~m}$.) akcentuojami high-tech elementai - ventiliacijos šachtos, metalinè tiltelio konstrukcija, interjeruose dominuoja metaliniai laiptų turèklai, nors pastato koncepcija daugiau orientuota i kontekstą, nei i techninès estetikos stilistiką. Panašūs sprendimai naudojami ir vèlesniuose objektuose, pavyzdžiui, lengvų konstrukcijų, stiklinis prekybos centro „Akropolis“ Vilniuje (archit. G. Jurevičius, A. Nasvytis 2002 m.) (99 pav.) iejjimo stogelis ir iškabą laikanti konstrukcija meninès raiškos požiūriu neturi nieko bendra su pagrindiniu pastato tūriu, tačiau architektūrinę formą praturtina kaip akcentai, sutelkiantys dèmesi i iejjimą ir komplekso pavadinimą. Administracinio pastato Vilniuje (archit. A. Asauskas, V. Kančiauskas 2005 m.) (100 pav.) architektūrinejje raiškoje, high-tech elementai naudojami pasvirusiai pėsčiujų rampos konstrukcijai, kuriai suteikus techninès estetikos bruožų sukuriamas dominuojantis architektūrinis akcentas, neįtakojantis 
vientisos, artikuliuotų geometrinių tūrių administracinio pastato formos. Panašus architektūrinis sprendimas matomas prekybos centre Jurbarke (archit. „L\&G Projektai“ 2008 m.). Kaip vieną išraiškingesnių plastiško high-tech elemento panaudojimo atvejų, galima išskirti prekybos centro „Europa“ Vilniuje (archit. A. Ambrasas ir kt. 2002 m.) (101 pav.) stogo konstrukciją. Sudetinga plieno, aliuminio ir stiklo forma dominuoja pastato interjere, veikia kaip pagrindinis šviesos šaltinis, tuo tarpu iš išorès veikia kaip monumentali, plastiška forma, prisitaikanti ir papildanti pagrindini gatvès fasadą.

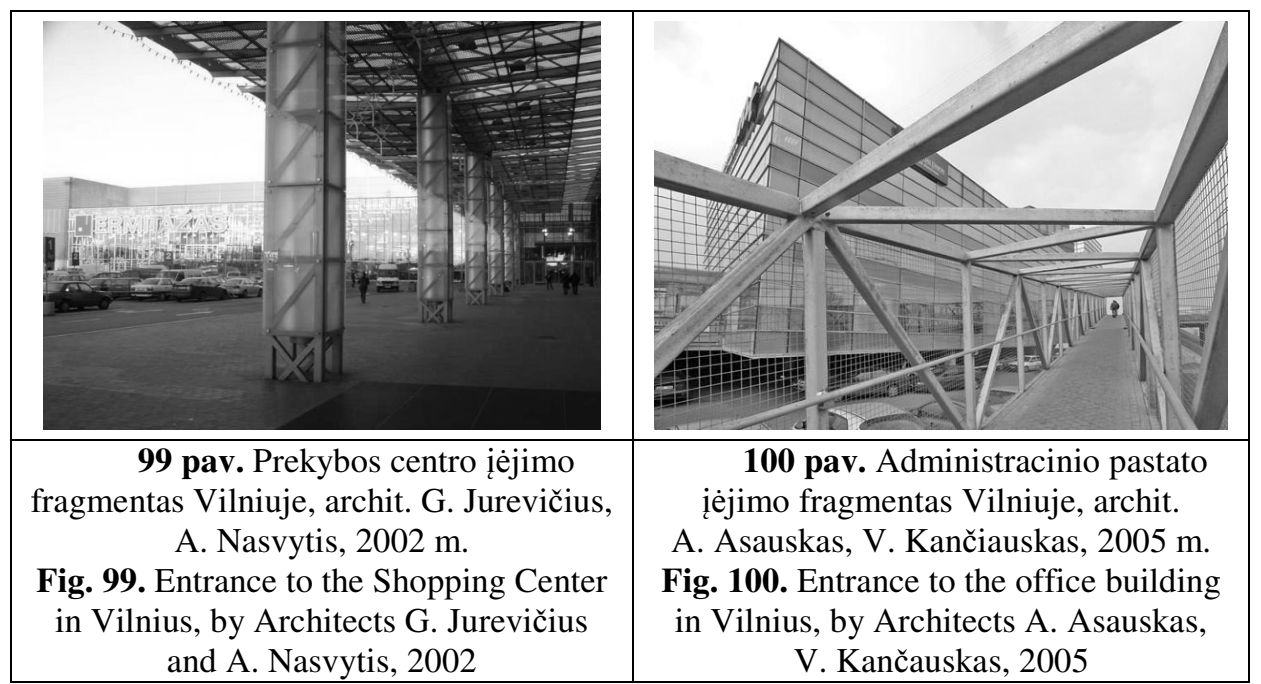

\begin{tabular}{|c|c|}
\hline 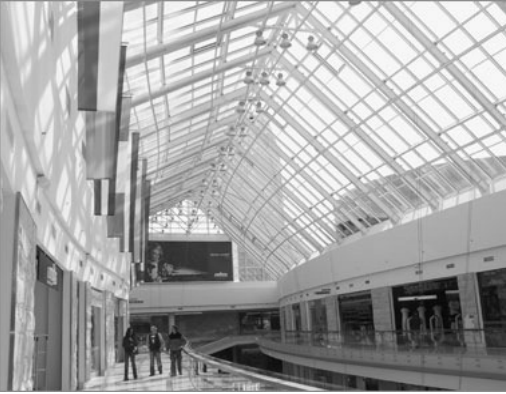 & , . \\
\hline $\begin{array}{l}\text { 101 pav. Prekybos centro } \\
\text { Europa Vilniuje interjeras, archit. } \\
\text { A. Ambrasas, } 2002 \mathrm{~m} \text {. } \\
\text { Fig. 101. Interior of the shopping } \\
\text { center Europa in Vilnius, by } \\
\text { Architect A. Ambrasas, } 2002 \\
\end{array}$ & $\begin{array}{c}102 \text { pav. Litexpo paroduc centro } \\
\text { Vilniuje interjeras, archit. R. Palekas, } \\
2006 \mathrm{~m} \text {. } \\
\text { Fig. 102. Interior of the exhibition center } \\
\text { Litexpo in Vilnius, by Architect R. Palekas, } \\
2006 \\
\end{array}$ \\
\hline
\end{tabular}

Fragmentiški high-tech architektūros bruožai pastebimi ir visuomeninių bei prekybos objektų interjeruose. Eklektiška prekybos centro „Promenadas“ Vilniuje 
(archit. G. Pociūnas, L. Lazauskas 2000 m.) fasadų raiška vidinėse erdvėse pakeičiama high-tech estetika. Atviros stogo konstrukcijos pabrěžiamos jas nudažant ryškiomis spalvomis, palubeje išvedžioti nerūdijančio plieno vėdinimo kanalai ir fluorescencinių šviestuvų tinklas primena pramoninio pastato interjerą. XX a. antros pusès brutalizmą primenantis „Stiliaus fabrikas“ Vilniuje (archit. D. Nainys, S. Gricius 1999 m.), fasadų menine raiška primena Japonų betono estetiką, tačiau vidinès erdvès artimesnès high-tech architektūrai. Čia dominuoja betono ir metalo paviršiai, atvirai išdèstytos inžinerinès komunikacijos, funkcionalaus dizaino šviestuvai ir baldai, atviri konstrukciniai elementai. Panašus architektūrinis sprendimas pastebimas parodų centro „Litexpo“ naujajame korpuse, Vilniuje (archit. R. Palekas ir kt. 2006 m.) (102 pav.).

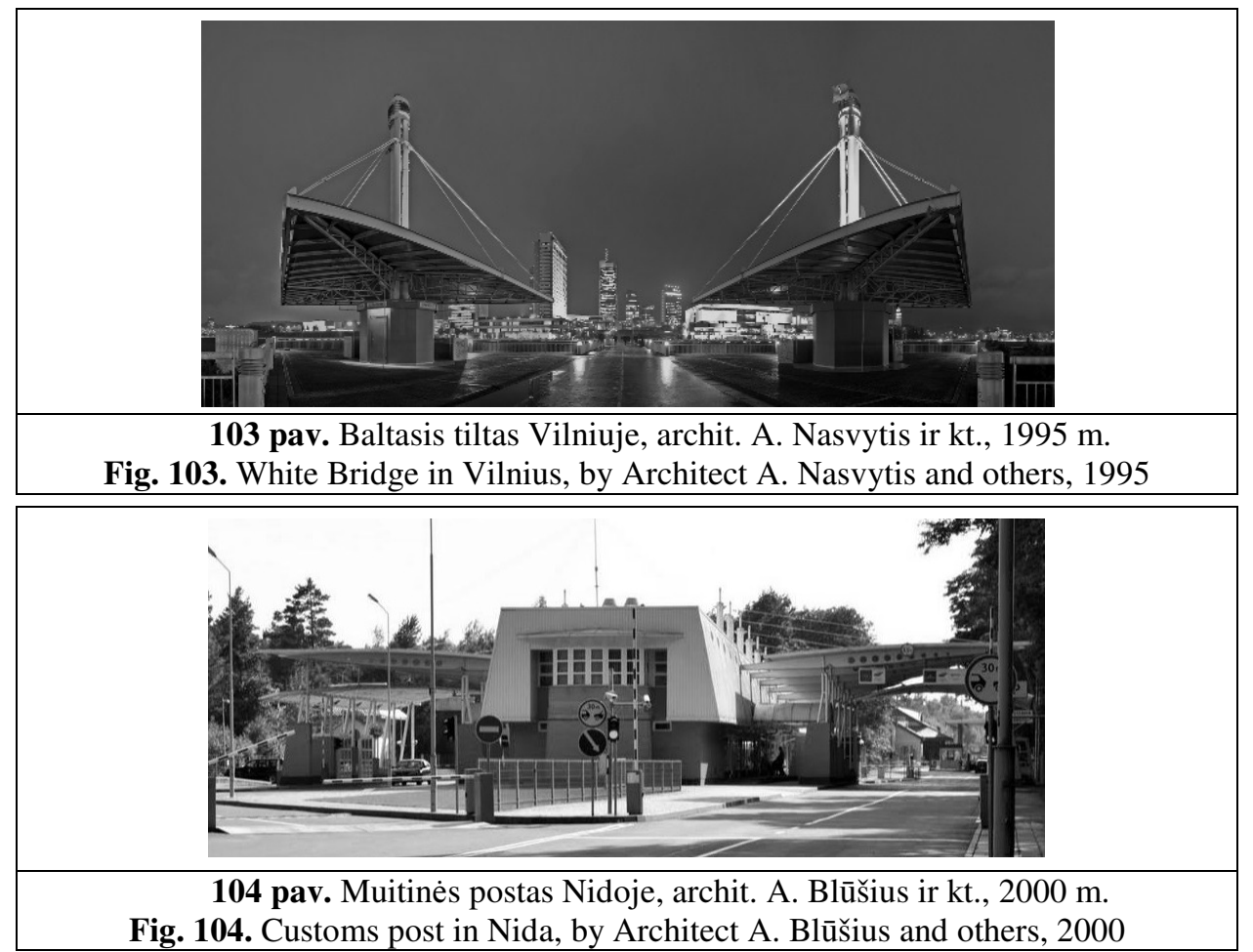

Bioninių formų high-tech estetika pasižymi Baltojo tilto Vilniuje, apžvalgos aikštelių lengvų konstrukcijų stoginès (archit. A. Nasvytis ir kt. 1995 m.) (103 pav.), sukuriančios vertikalų akcentą dešiniająme Neries krante ir pabrěžiančios organiškai i reljefą įkomponuotas kavinès patalpas. Ant dviejuc vertikalių atramų užmauti trikampiai lapo formos stogai, prilaikomi atotampų, pabrezžia tilto simetrijos aši, tuo sustiprindami jo, kaip jungties tarp naujojo ir senojo miesto, simbolinę prasmę. Plastiška high-tech ekspresija dominuoja ir Klaipèdos teritorinès muitinès, Nidos posto pastate, Neringoje (archit. A. Blūšius 
ir kt. 2000 m.) (104 pav.). Geltonų plytų mūro pirmasis aukštas naudojamas tarsi pagrindas, skirtas pabrèžti plastiškas antrojo aukšto formas. Pravažiuojami korpusai perdengti lenktais, dviejų dalių profiliuotos skardos sparnais, kurių ịlinkị pabrěžia kiaurymètos metalinès konstrukcijos. Lengvumo îspūdi sustiprina pagrindinio korpuso atotampų tinklas. Bioninę pastato prigimtị sustiprina išilgai pastato įvesta simetrijos ašis, lygiagreti važiuojamajai daliai.
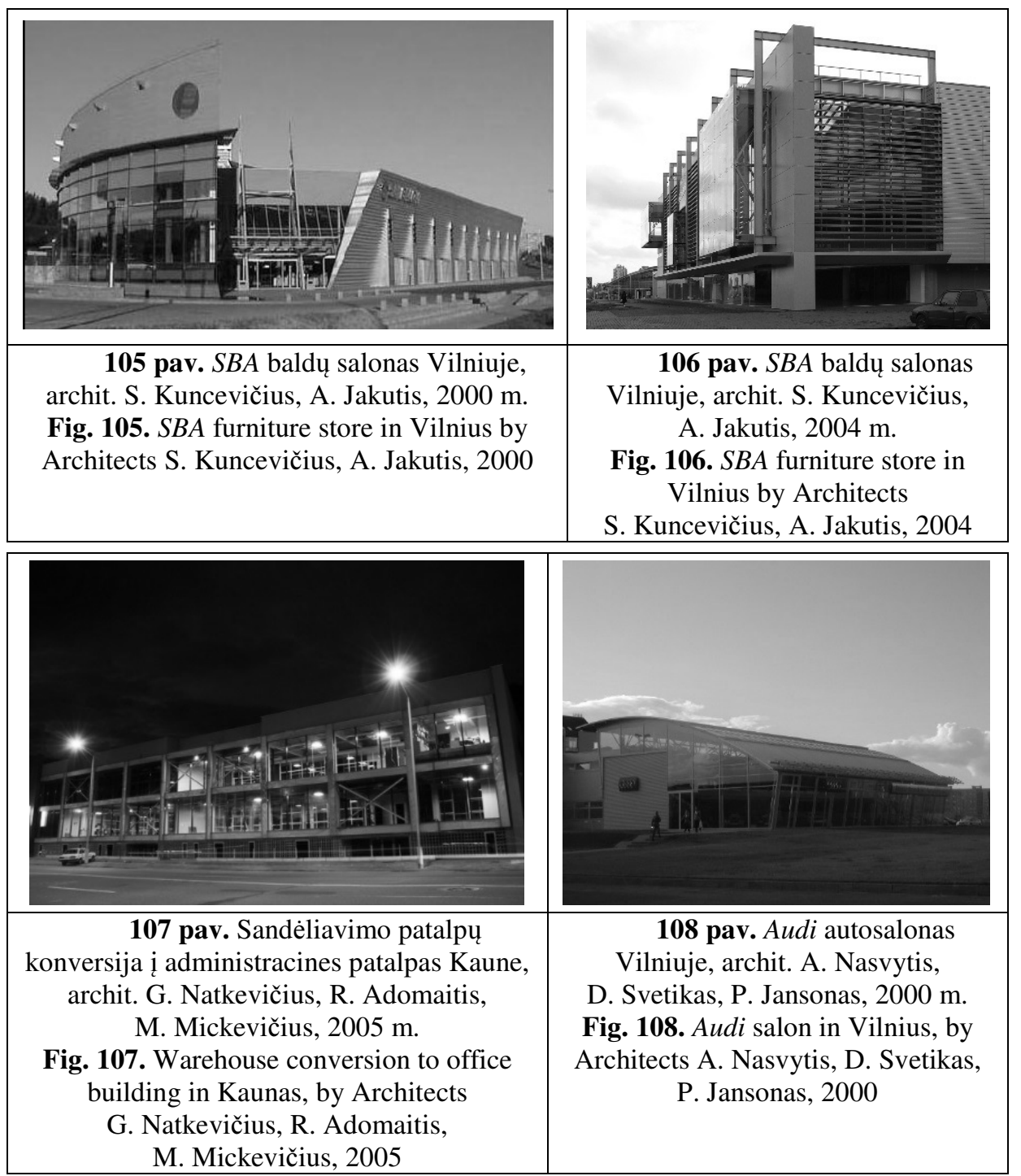

Išraiškingų tūrių dinamika išsiskiria prekybos centro „Laisve““ (buv. „SBA baldai“) pastatas Vilniuje (archit. S. Kuncevičius, A. Jakutis 2000 m.) (105 pav.). 
Plieninès fasado detalès, cinkuotos skardos apdaila čia derinama su lenktomis stiklo plokštumomis, tinko ir medžio intarpais. High-tech įspūdị sustiprina įvairūs ažūriniai elementai, stogeli prilaikantys trosai, nepridengti masyvūs ortakiai, apšvietimo elementai ir pan. Kiek nuosaikesne, tačiau taip pat high-tech architektūrai būdinga menine raiška pasižymi architekto S. Kuncevičiaus ir A. Jakučio suprojektuotas „SBA baldų“ salonas Vilniuje (2004 m.) (106 pav.). Ilgas Ukmergès gatvès fasadas skaidomas stikliniais erkeriais, metaliniu ažǔru bei vertikaliais konstruktyviniais elementais. Pastatas kontekstualus, savo architektūrine raiška siekiantis prisitaikyti prie susiklosčiusio aplinkinio užstatymo, tačiau tuo pačiu yra vientisas ir atspindintis high-tech architektūros principus. Sèkmingo esamo užstatymo panaudojimo pavyzdys galètų būti sandeliavimo patalpų rekonstrukcija ir administracinių patalpų įrengimas Kaune (archit. G. Natkevičius, R. Adomaitis, M. Mickevičius 2005 m.) (107 pav.), kuomet high-tech architektūrai būdinga struktūrinè ekspresija dominuoja išoreje, o viduje išryškinama buvusių sandèliavimo patalpų konstrukcija, bei praturtinama high-tech elementais - šviestuvais, atviromis ventiliacijos šachtomis, poliruoto metalo paviršiais.

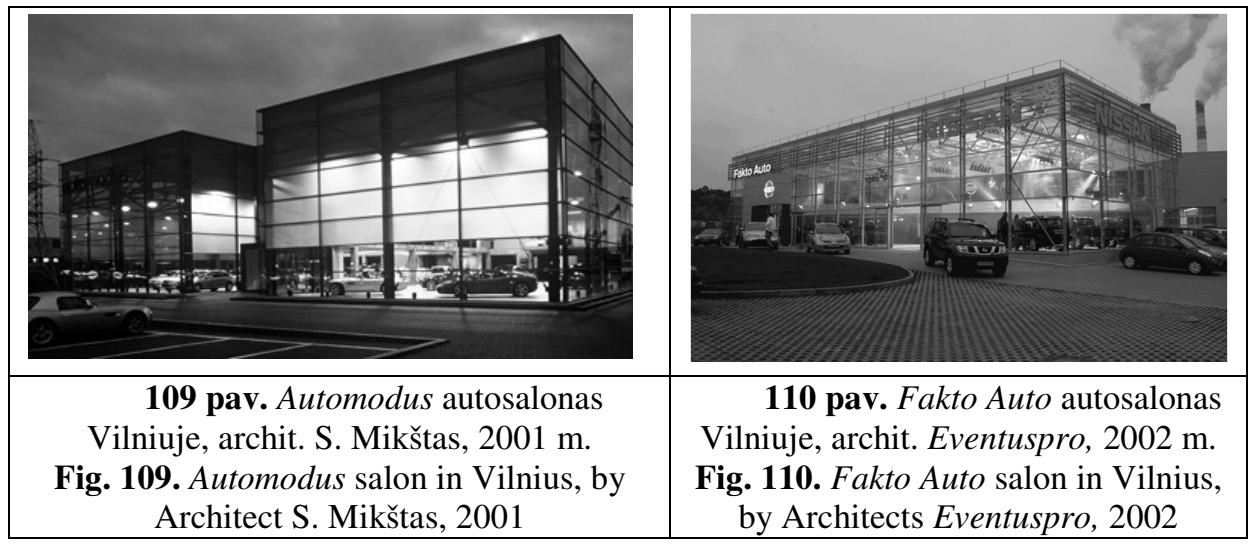

Techninė estetika matoma dideleje dalyje autosalonų ir autoservisų, sukurtų 1990-2010 m. Pavyzdžiui, architekto Gedimino Jurevičiaus suprojektuotas „Peugeot” autosalonas Kaune (2001 m.), pasižymintis medinių plokštumų ir metalo estetikos sinteze, „Toyota“ autosalonas Kaune (2004 m.) ir „Audi““ autocentras Vilniuje (archit. A. Nasvytis, D. Svetikas, P. Jansonas 2000 m.) (108 m.) kuriuose atsiskleidžia stiklo ir metalo konstrukcijų sintezè, autoservisas Savanorių prospekte, Vilniuje (A. Žalys, S. Vinciūnas 2000 m.), kur monumentalus, netikètu kampu pasviręs metalinis tūris pabrèžiamas high-tech architektūrai būdingais elementais - nerūdijančio plieno dūmtraukiu, dengta iejjimo rampa. Slick-tech fasadų raiška ir high-tech interjero sprendimai pastebimi automobilių salone „Automodus“, Vilniuje (archit. S. Mikštas 2001 m.) 
(108 pav.), automobilių salone „Fakto auto“, Vilniuje (archit. „Eventuspro“ 2002 m.) (109 pav.), automobiliu salone „Sostena“, Kaune (archit. A. Kančas, L. Kazakevičiūtė 2002 m.), „Kia” autosalone Vilniuje (archit. A. Nasvytis ir kt. 1998 m.), Automobilių centre „Mitsubishi“ Vilniuje (archit. K. Pempé, V. Lukoševičius, 1996 m.).
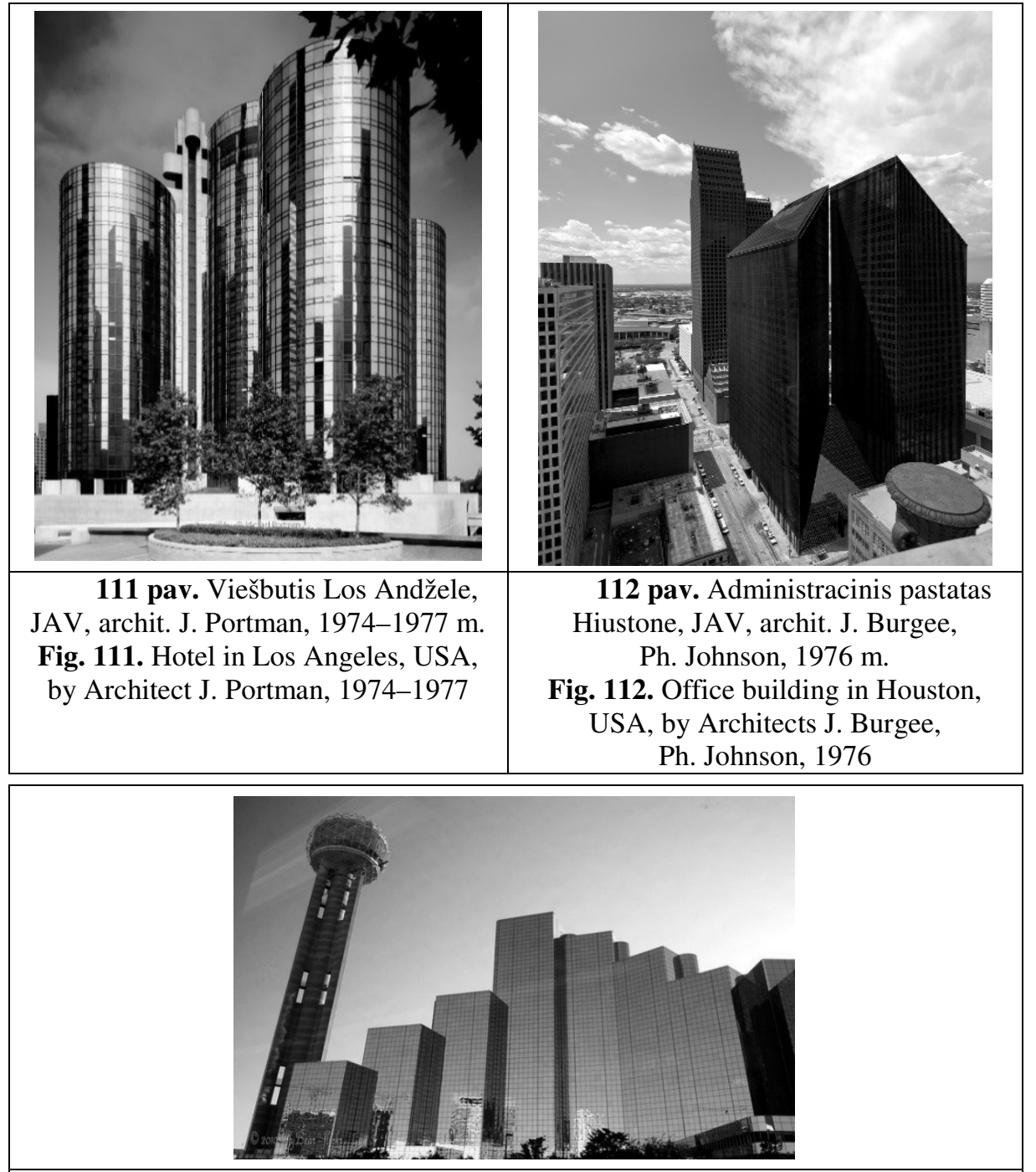

113 pav. Viešbutis Dalase, JAV, archit. W. Becket, 1976-1978 m.

Fig. 113. Hotel in Dallas, USA, by Architect W. Becket, 1976-1978

Jeigu high-tech architektūra technologinę pažangą akcentavo hiperbolizuodama pastato struktūrą, tai slick-tech architektūroje pastebima 
paviršių estetikos hiperbolizacija. Terminas slick-tech apibūdina technologijų triumfą išreiškiant ji ypač glotnių ir spindinčių paviršių pagalba. Šiam tikslui pasiekti naudojamos tik modernios medžiagos - lakštinis plienas, poliruoto aliuminio plokštès, ịvairūs aplinką atspindintys plastikai, šviesi emalè ir atspindintis ar veidrodinis stiklas. Taip sukuriamas tarsi šlapio paviršiaus įspūdis, kuris savo atspindžiais sustiprina šviesos - šešèlio kontrastus, tačiau tuo pačiu panaikina formų kontūrus, suniveliuoja ribas tarp skirtingų medžiagų. Kuomet atspindžiai ir blizgesys užpildo pastato architektūrinę raišką, tūriškai naudojamos pakankamai primityvios formos. Architekto N. Fosterio teigimu, ,slick-tech raiškai pakanka lygios sienos“ (Jencks 1982). Ch. Jencks pastebi, jog slick-tech architektūra pirmines geometrines formas adaptavo iš minimalistinio meno ir jas šiek tiek transformavo. Naudojami penkių ir daugiau briaunų tūriai taip pat jų kompozicijos. Nevengiama cilindrų o taip pat banguotų elementų, priešingų (plastiškų ir griežtų) formų susikirtimų. Slick-tech estetika dažnai naudojama administracinès paskirties korporacijų ir bankų pastatuose, kadangi architektūriné raiška atitiko siekiamą sukurti įspūdį - nuosaikaus, aplinkai neabejingo griežtumo ir solidumo. Dar kitokị efektą slick-tech paviršių raiška sukuria tamsiu paros metu. Iš vidaus apšviesto pastato architektūrinè forma pakinta. Griežtos geometrinès formos tampa permatomos, dažnai galima įžvelgti pastato struktūrinę sąrangą, pastatas pavirsta traukos centru, apšviečia aplinką, tampa tarsi šviestuvu (Valevičius 2010).

Aiškiai artikuliuotų geometrinių tūrių slick-tech architektūrai būdinga menine raiška pasižymi architekto J. Portman viešbučių projektai Čikagoje, JAV (1967-1971 m.), Atlantoje JAV (1964-1967 m.) ir Los Andžele, JAV (19741977 m.) (111 pav.). Kiek sudètingesnès formų kompozicijos būdingos J. Burgee ir $\mathrm{Ph}$. Johnson architektu suprojektuotiems aukštuminiams pastatams Mineapolyje, JAV (1973 m.) ir Hiustone, JAV (1976 m.) (112 pav.), taip pat W. Becket viešbučio pastatui Dalase, JAV (1976-1978 m.) (113 pav.).

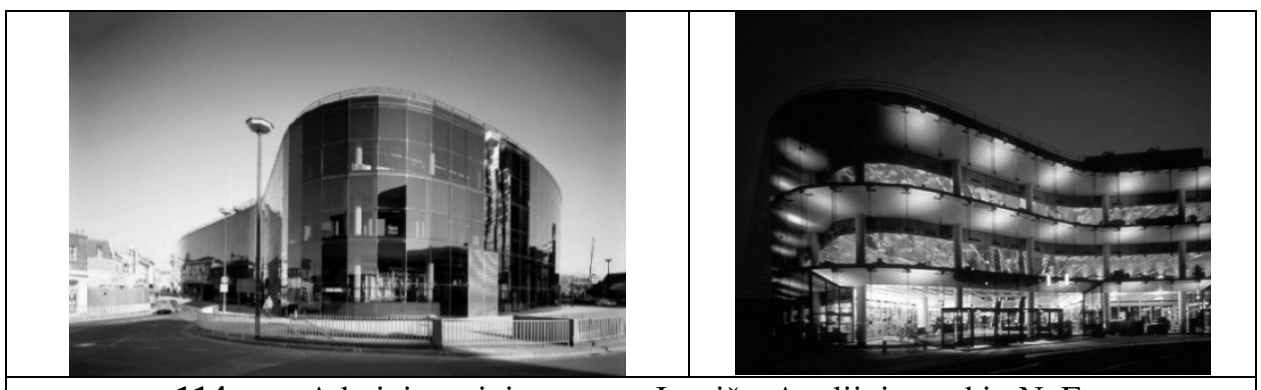

114 pav. Administracinis pastatas Ipsviče, Anglijoje, archit. N. Foster, 1972-1975 m.

Fig. 114. Office building in Ipswich, England, by Architect N. Foster, 1972-1975 
Kaip vienas iš įsimintinesnių slick-tech architektūrinès raiškos objektų išskiriamas administracinis pastatas Ipsviče, Anglijoje (archit. N. Foster 19721975 m.) (114 pav.). Sudètinga urbanistinè situacija sąlygojo nestandartinę pastato formą. Banguojantys fasadai atkartoja vingiuotų gatvelių įlinkius, tamsinto stiklo plokštumos atspindi transporto, pėsčiujų srautus, aplinkini užstatymą. Laisvo planavimo (konstrukcinè sąranga paremta kolonų ir perdangų tinklu) ir vientiso tūrio pastate dera administracinès patalpos ir darbuotojų laisvalaikio erdvès, kuriose yra net sporto sale ir baseinas. Komplekso architektūrinè raiška sprendžia ir kontekstualumo klausimą. Berèmis stiklas veikia tarsi lengva užsklanda tarp vidaus ir išorès, o plastiška forma prisitaiko prie susiklosčiusio užstatymo.

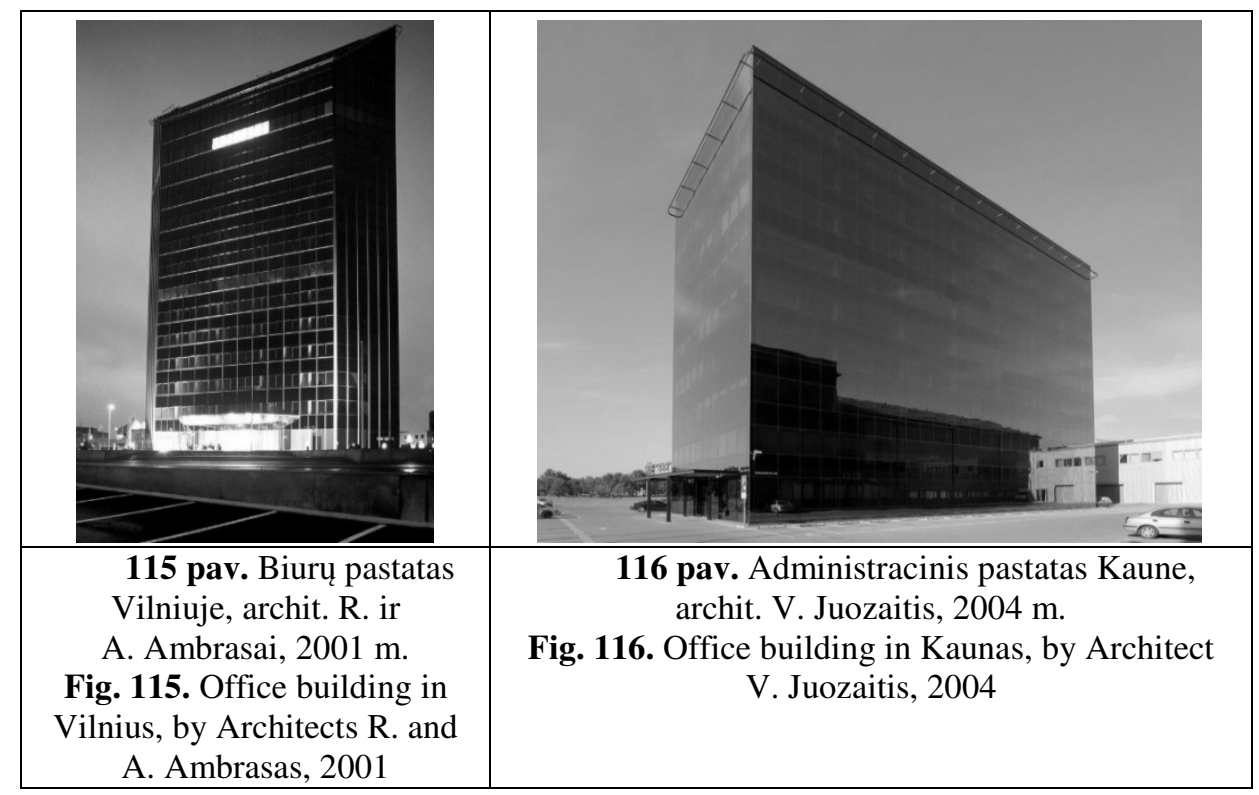

Lietuvos, kaip ir užsienio architektūroje, slick-tech paviršių meninè raiška visų pirma pastebima visuomeniniuose ir administraciniuose pastatuose. Architektų Ritos ir Audriaus Ambrasų suprojektuotas vienas pirmujjų aukštuminių biurų pastatų „Hanner“, Vilniuje (2001 m.) (115 pav.), pasižymi grežtais kontūrais ir monumentalia forma, apvilkta spindinčiu stiklo paviršiumi. Vienintelis elementas suardantis minimalią fasadų architektūrinę raišką - tai evakuacinių laiptinių vertikalè. Pastato architektūrinèje formoje galima įžvelgti minimaliai formai būdingo asketiškumo, tačiau bendra pastato estetika tikriausiai artimesnè Mies van der Rohe konstruktyvizmui. Architekto teigimu, paprastas pastato tūris yra tarsi ženklas (Lupeikis 2002), toki ispūdị sustiprina tai, jog pirminè geometriné forma neskaidoma nei horizontaliu, nei vertikaliu ritmu, minimalistinès plokštumos optiškai didina pastatą. 
Administracinis banko pastatas Kaune (archit. V. Juozaitis 2004 m.) (116 pav.) galètų būti kitas panašios, aiškių geometrinių slick-tech tūrių architektūrinès raiškos pavyzdys. Kompleksas sudarytas iš dviejų susikertančių korpusų, sudarančių $\mathrm{T}$ formą. Aukštuminis korpusas pasižymi asketiška minimalistine raiška, o dviejų aukštų žemutiniame korpuse įvedama raudono poliruoto akmens ritmika. Tokiu būdu išryškinamas stiklinis monumentalus tūris, neprarandant slick-tech architektūrai būdingo reprezentatyvumo.

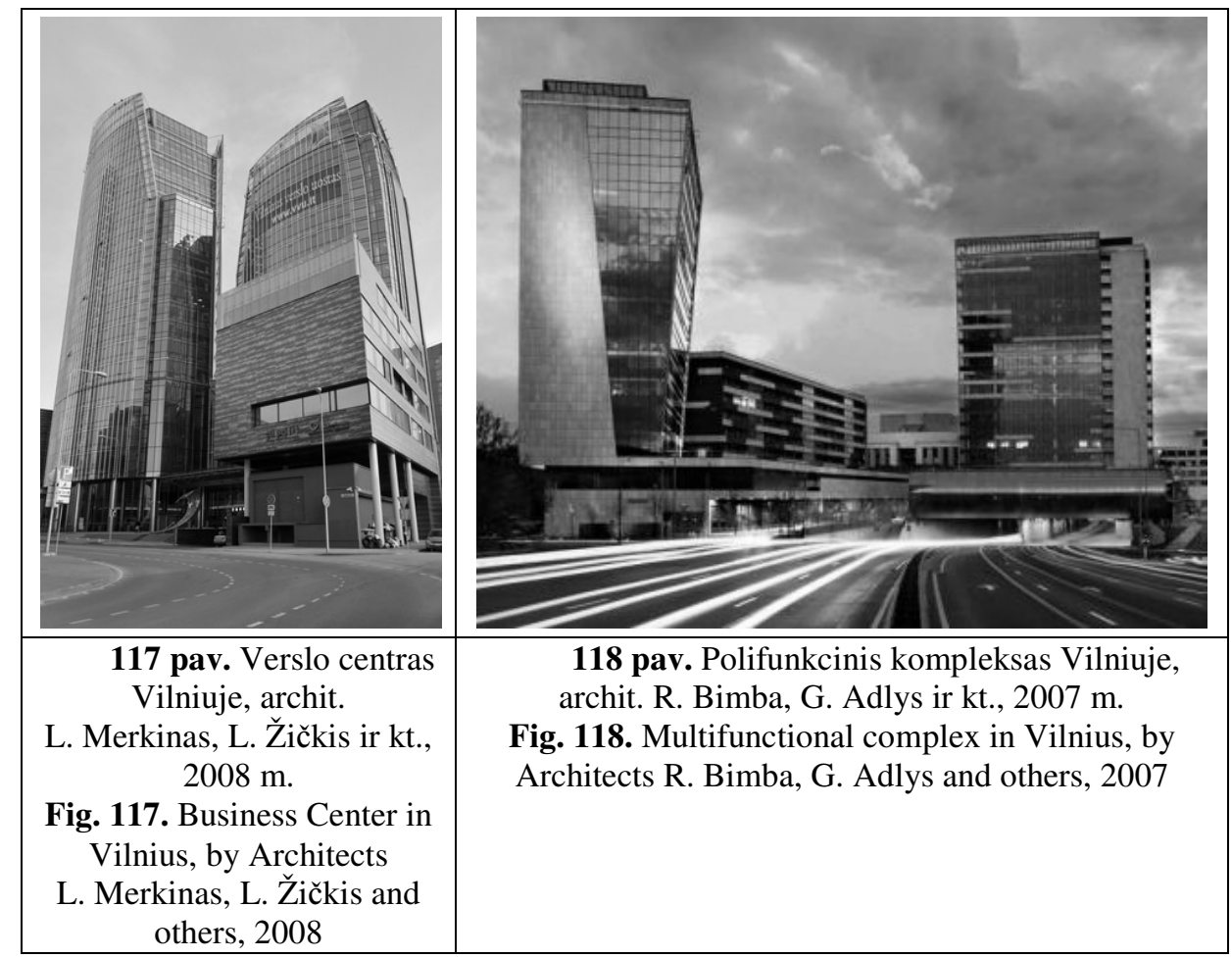

Verslo centre „Verslo uostas“, Vilniuje (archit. L. Merkinas, L. Žičkis ir kt. 2008 m.) (117 pav.) ir polifunkciniame komplekse „Vilniaus vartai” (archit. R. Bimba, G. Adlys ir kt. 2007 m.) (118 pav.) slick-tech paviršiai traktuojami kaip atskiri architektūriniai elementai, vietomis atitrūkstantys nuo pagrindinio pastato tūrio, pabrezžiantys formos daugiasluoksniškumą. Biurų pastatuose „Victoria“ Vilniuje (archit. R. Palekas, R. Bèčius ir kt. 2004-2005 m.) (119 pav.) ir „BCC” Vilniuje (archit. S. Pamerneckis ir kt. 2002-2003 m.) (120 pav.), verslo centre „Europa”, Vilniuje (archit. A. Ambrasas ir V. Adomonyte 2002-2004 m.) (121 pav.), Vilniaus miesto savivaldybès pastate (archit. A. E. Paslaitis ir kt. 2002-2004 m.) slick-tech paviršių raiška papildoma kitomis medžiagomis, spalvotų panelių akcentais, akmens masès plokštėmis, plytų mūro intarpais. Tokiu 
būdu universali slick-tech estetika igauna kontekstualumo, kritinio regionalizmo bruožų.

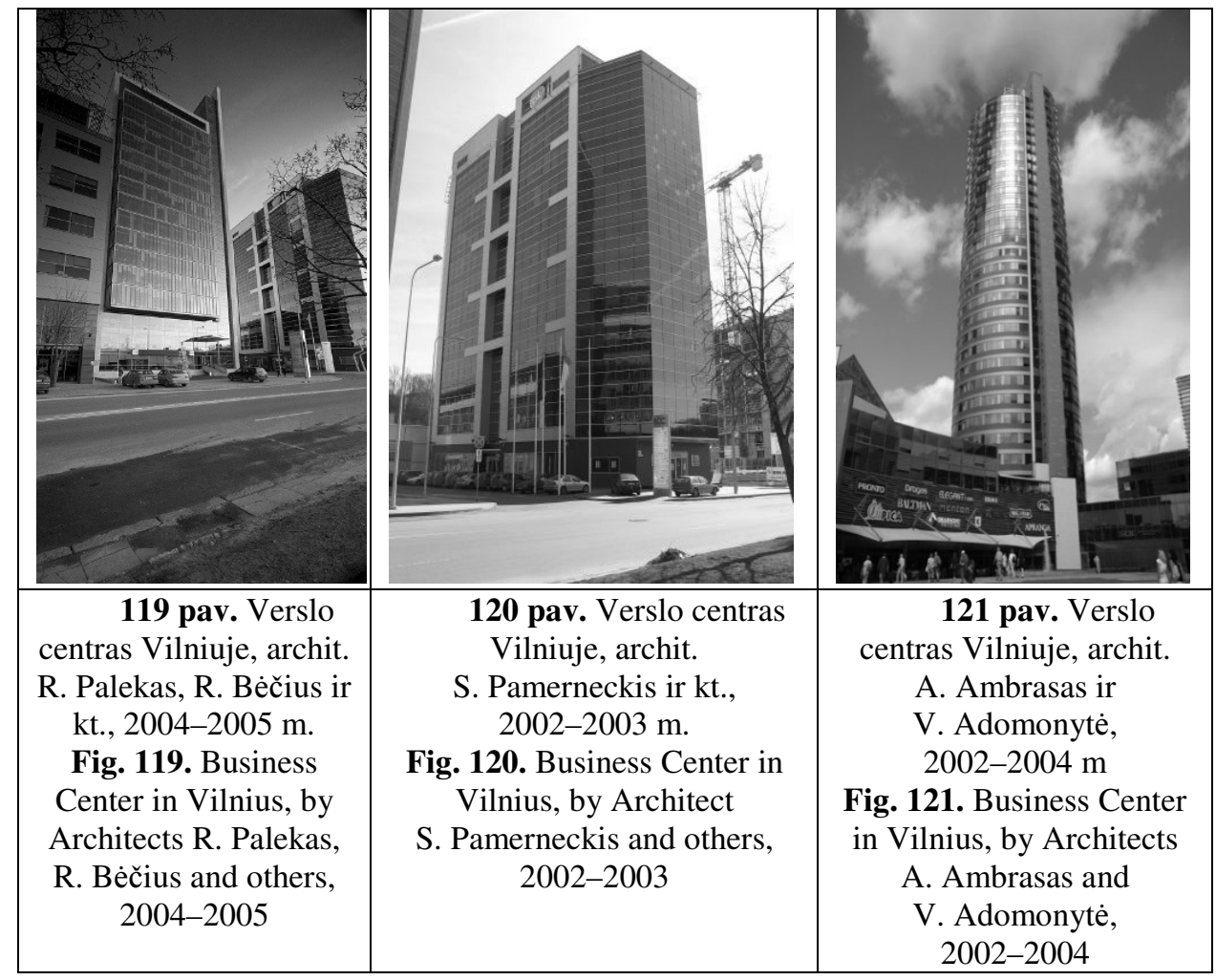

Kiek įmantresne tūrine išraiška išsiskiria polifunkcinio komplekso „Domus galerija“ pastatas Vilniuje (archit. R. Bimba 2004 m.) (122 pav.). Pagrindiniame dviejų aukštų prekybinio korpuso fasade naudojamos ištisinès stiklo plokštumos ir aliuminio paneliai, antrajame - administraciniame korpuse - tamsinto stiklo paviršiai. Plastiškos formos administracinio korpuso tūrị papildo lengvų konstrukciju akcentai, ikirstos evakuacinès laiptinès. Panašūs kompleksiški tūriniai sprendimai pastebimi automobilių centre Ukmergès g., Vilniuje (archit. A. Ambrasas 1999 m.), kur aštrių formų geometrinè forma uždedama ant ovalo formos pirmojo aukšto, derinama stiklo ir aliuminio medžiagų slick-tech estetika, taip pat komerciniame komplekse Žirmūnuose, Vilniuje (archit. „Architektūros kūrybinè grupé" 2003 m.).

Išskirtinès architektūros objektas, pasižymintis unikaliu medžiagų ir formų deriniu, yra „Swedbank“ banko pastatas Vilniuje (archit. A. Ambrasas 2009 m.) (123 pav.). Komplekse apjungiamas aiškių geometrinių formų slick-tech paviršių blizgesys ir high-tech struktūrinè ekspresija, kuri pabrèžiama laužytų medinių terasų ritmu ir ovalo formos žalių plotu intarpais. Pastatas išdèstytas 
kontekstualiai, tūrines formas derinant su greta esančiu „Lietuvos“ viešbučiu, ị gatvès pusę atgręžiant prabangiomis medžiagomis apdailintą, žvilgančių paviršių, griežtų formų fasadą. Upès pusèje - laisvalaikio zona, kurioje laužyta, gamtines pakrantès formas atkartojanti terasa atveria senosios miesto dalies vaizdus. Šiame objekte profesionaliai derinamos techninès estetikos ir kritinio regionalizmo meninès raiškos priemonès.

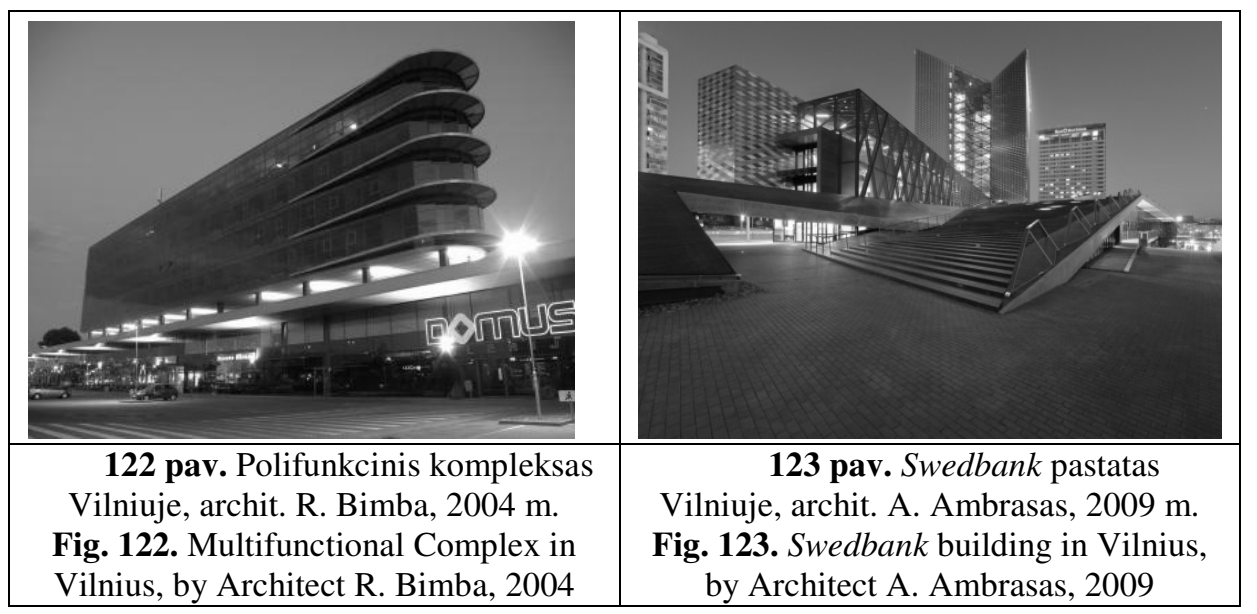

Ekspresyvi struktūrinė raiška dominuoja polifunkciniame komplekse Kaune (archit. G. Natkevičius ir kt. 2008 m.) (124 pav.). Pirmajjame aukšte išdèstytos restorano ir komercinès patalpos, nuo antrojo iki devintojo - gyvenamosios. Pastato tūris sudarytas iš dviejų sluoksnių, pirmasis - stiklo plokštuma sutampanti su kolonų tinklu, ir sudalinta balkonų horizontalemis. Antrasis - struktūrinis tinklas, formuojantis vientisą pastato architektūrinę formą, kur struktūra virsta ornamentu. Panašus sprendimas igyvendintas „Pirklių klubo“ pastate Vilniuje (archit. A. Trimonis ir kt. 2012 m.) (125 m.). Šiuo atveju high-tech estetika atsiskleidžia kaip struktūrinis ornamentas, kuris pabrèžia slick-tech paviršius. Be techninės estetikos čia svarbus ir kontekstualumo aspektas. Kontrasto principu istoriniam užstatymui modeliuojama tiek naujojo pastato forma, tiek išoriné jo išraiška. Viduje dominuoja funkcionaliai išplanuotos erdvès, lakoniškas pastato tūris nekontrastuoja vidinių erdvių pragmatiškumui, architektūrinę raišką praturtina išryškinti struktūriniai elementai, kurie ir sukuria naujojo pastato atpažįstamumą. Architektai ,žaidžia“ forma, dekoratyviniai elementai nėra naudojami, viso pastato estetiką atspindi jo konstrukcinè sąranga. Tai leidžia $\mathfrak{i}$ pirmame plane palikti istorinius pastatus, kurie ir formuoja bendrą komplekso vaizdą, paliekant naujajji pastatą tarsi foną (Mankus 2012).

Panašaus pobūdžio objektas, tiesa kiek nuosaikesnis istorinio užstatymo atžvilgiu - Halès turgaus rekonstrukcija Vilniuje (archit.V. Kormilcevas, M. Mankus, V. Lužys, 2007 m.). Šio objekto architektūroje dominuoja techninès 
estetikos principai - atviros konstrukcijos, inžineriniai įrengimai, vidinès erdvès sudalijamos berèmio stiklo plokštumomis. Ypatinga pagarba išlaikoma esamam užstatymui. Naujasis pavilijonas nuo aplinkinių pastatų tarsi atsitraukia pagarbiu atstumu, ten kur reikia funkciškai susijungti, tam naudojamos stiklo konstrukcijos siekiant pabrěžti kontrastą esamam užstatymui. Pilkai melsvas stiklas taip pat oponuoja aplinkiniam geltonų plytų mūrui, tačiau nenustelbia jo, o kaip tik pabrěžia senamiestinį užstatymą. Antrasis komplekso korpusas - administracinis. Jis projektuojamas panašiu principu, kaip ir prekybos pavilijonas, stiklinis tūris atgrežiamas į mūro sieną (Kučinskas 2006).

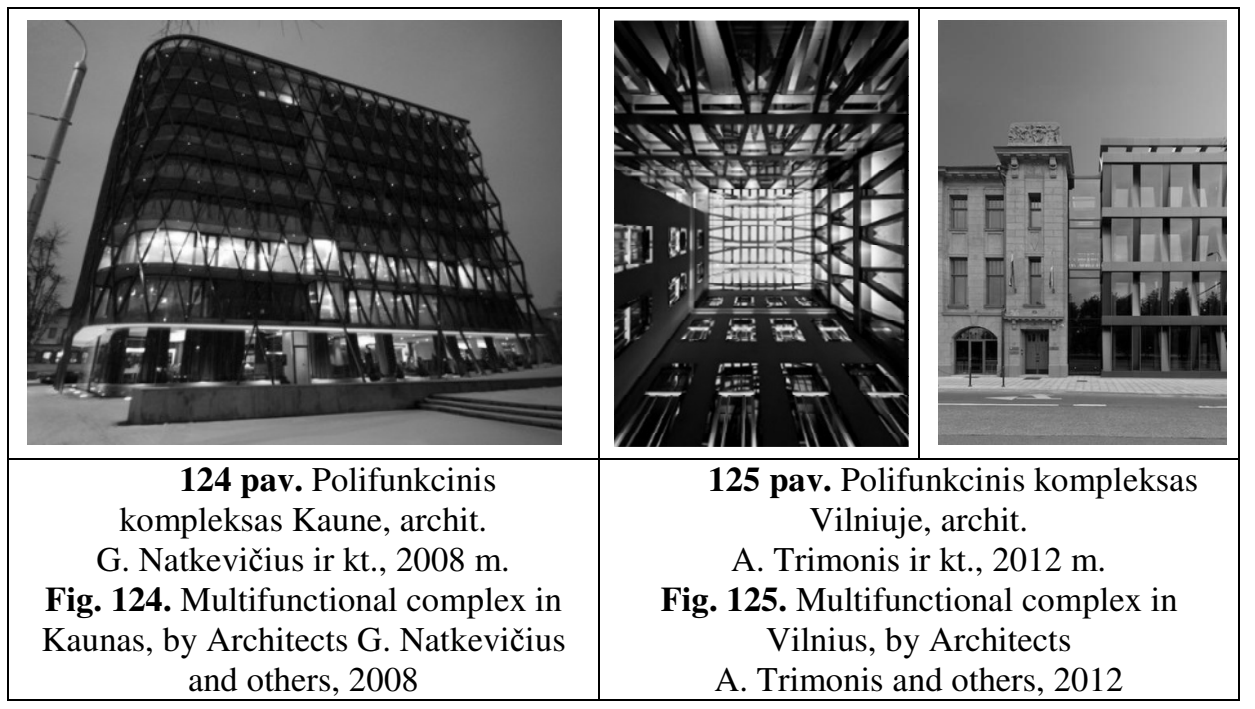

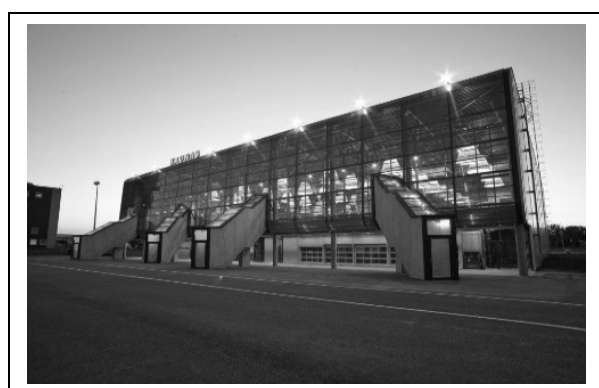

126 pav. Tarptautinis Kauno oro uostas, archit. G. Natkevičius, $2008 \mathrm{~m}$.

Fig. 126. Kaunas International airport, by Architect G. Natkevičius, 2008

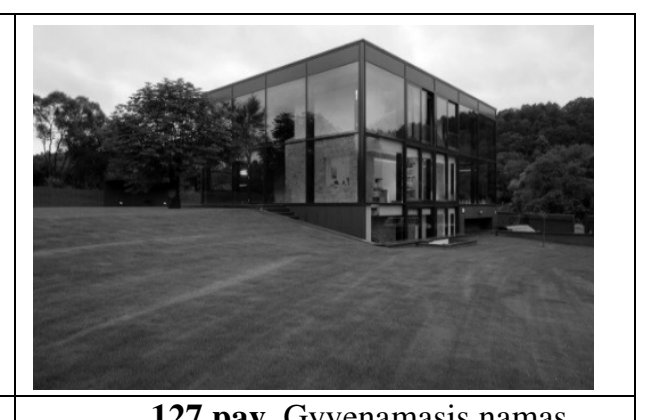

127 pav. Gyvenamasis namas Vilniuje, archit. G. Natkevičius, $2008 \mathrm{~m}$. Fig. 127. Dwelling house in Vilnius, by Architect G. Natkevičius, 2008

High-tech ir slik-tech architektūrai būdingos meninès raiškos sintezè matoma ir kituose projektuose: Tarptautiniame Vilniaus oro uoste (archit. L. Vaitys 1994 m.), viešbutyje „Šachmatinë“, Palangoje (archit. G. Likša 1997 m.), 
administraciniame pastate Vilniuje (archit. S. Pamerneckis ir R. Noreikis 1999 m.), verslo centre „Hanner“, Vilniuje (archit. A. Ambrasas ir V. Adomonyte 1998-2000 m.), administraciniame „Kraft“ imonès pastate, Kaune (archit. A. Kančas 2001 m.). Slick-tech paviršiais apgaubta high-tech estetika atsiskleidžia Kauno oro uosto išvykimo terminale (126 pav.) (archit. G. Natkevičius 2008 m.), taip pat autosalone „Mitsubishi““ (archit. K. Pempè, V. Lukoševičius ir kt. 1999 m.). Individualaus namo projekte, Vilniuje (127 pav.) (archit. G. Natkevičius 2007 m.) high-tech ir slik-tech raiška primena anksčiau aptartus architektų H. Shulitz, M. Hopkins ir W. Sobek pavyzdžius.

Išskirtinis techninès estetikos pavyzdys, kuriame susipynusi high-tech ir sliktech meninè raiška, galètu būti etnokosmologijos muziejaus rekonstrukcija Kulonyse, Molètu raj. (archit. R. Krištapavičius ir A. Gudaitis 2008 m., pirminio projekto autorius V. Lisauskas 1990 m.) (128 m.). Kompleksui rekonstruoti panaudojami esami statiniai, tiesa kalno papėdeje lankytojus pasitinka naujas polifunkcinis elipsès formos statinys, kuriame ịrengtos bilietų kasos, infocentras, konferencijų salè. Panašus motyvas atkartojamas ir kalno viršūnejje, kuomet panašios konfigūracijos tūris užmaunamas ant esančių observatorijos bokštų sukuriant sklendimo ore iliuziją. Šiame objekte labai aktyvus emocinis high-tech užtaisas, susijęs ir su pastato paskirtimi.

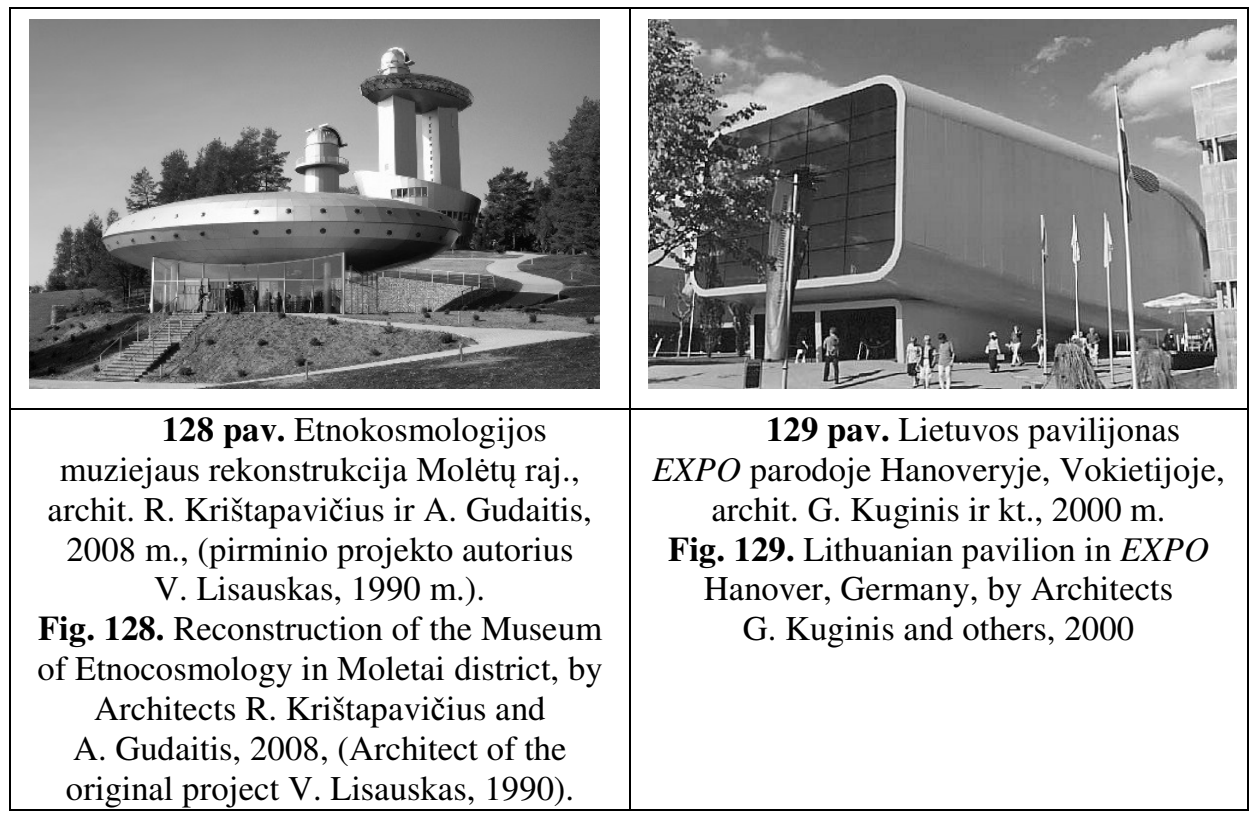

Panašia emocija pasižymi ir administracinis pastatas Klaipėdoje (archit. M. ir A. Bučai 2005 m.). Utilitari pastato išvaizda turi slik-tech raiškos bruožų, tačiau čia akivaizdžiai matoma „pastato kaip prietaiso“ koncepcija aptarta anksčiau, 
šiame skyriuje. Autorių teigimu, gatvès fasadas imituoja prožektoriaus reflektorių (Vengalytė 2006). Pastatas funkciškai padalintas ị dvi zonas, priekyje, šalia gatvės fasado - klientu zona, už aliuminio pertvaros įrengta virtuvèlè ir pagalbinès patalpos. Kadangi pastatas priklauso dviems įmonėms, viduje jų plotai atskiriami tiesiog spalvomis, raudona ir mèlyna. Visa interjero estetika - itin utilitarinè. Vyrauja plastikas, aliuminis, paneliai. Lietuvos pavilijonas EXPO parodoje Hanoveryje, Vokietijoje (archit. G. Kuginis ir kt. 2000 m.) (129 pav.) taip pat išsiskyrè savo utilitaria išvaizda ir ,laikmečio dvasios“ koncepcija.

Autonominè paviršių raiška šiuolaikinèje architektūroje. Spindintys slick-tech paviršiai ir jų panaudojimo proveržis septintajame XX a. dešimtmetyje inicijavo susidomejjimą autonomine paviršių raiška architektūroje. Tai nèra išskirtinis atvejis, kadangi demesys paviršiams yra pastebimas visoje XX a. architektūroje, pavyzdžiui F. Lloyd Wright banguojantys fasadai, O. Niemeyer lenktos stiklo plokštumos. H. Gaudin, Herzog ir de Meuron taip pat daugelis kitu skyrė ypatingą dèmesi paviršių plastikai ir medžiagiškumui, tačiau architektūros tyrinètojai A. Tzionis ir L. Lefaivre pastebi, jog šiuolaikineje architektūroje, paviršiaus, kaip vieno iš pagrindinių architektūrinès formos kūrimo priemonių reikšmè išaugo. Pastebimai padaugejo bandymų architektūrinę raišką formuoti ne tūrinès - erdvinès sąrangos, bet daugiau išorinio apvalkalo pagalba (Tzionis 1992).

Architektūros tyrinètojai pastato ,apvalkalą““ išskiria kaip vieną iš architektūrinès formos apibūdinimų, šalia dydžio, spalvos, tekstūros ir pan., atskirdami ji nuo struktūrinès pastato formos. Andrew W. Charleson teigia, jog „,architektūrinè forma yra apvalkalas, apgaubiantis tūrị ar kontūrą. Šis supaprastintas požiūris ị architektūrinę formą leidžia mums ją atskirti nuo vidaus ir išorès struktūrinès sąsajos. Tai padeda suvokti, jog tas trijų dimensijų tūris, kurị mes matome, gali būti visiškai nesusijęs su vidine konstrukcine sąranga“" (Charleson 2005). K. Frampton išorinio apvalkalo sureikšminimą vadina tiesiog dekoratyvumu (Frampton 2007), D. Leatherbarrow ir M. Mostafavi paviršių raišką ịvardina kaip vieną svarbiausių $\mathrm{XX}$ a. antros pusès architektūrinès kalbos formantų (Leatherbarrow 2002), o K. Lupeikis teigia, jog XX a. pab. architektūroje issivyravus multimedijų priemonèms, iš esmès pakitus požiūriui i formą, fasadai traktuojami ne kaip plokštumos, o daugiau kaip apvalkalas (Lupeikis 2007).

Nagrinejjant architektūrinius paviršius, reikètų pažymèti, jog autonomiškas paviršių traktavimas architektūroje nèra išskirtinai šiuolaikinès architektūros bruožas. Apvalkalas, kaip vienas pagrindinių architektūrinès formos kūrimo elementų buvo atskiriamas dar tuomet, kai pastato forma ir konstrukcinè sąranga buvo tiesiogiai priklausoma viena nuo kitos. Šio koncepto pradininkas - Gottfried Semper, autonominių paviršių teoriją pristatęs XIX a. pabaigoje (Breitschmidt 2004). 
Šiuolaikinèje architektūroje įžvelgiama glaudi kompiuterinio projektavimo ir paviršių teorijos architektūroje sintezè. Skaitmeninè projektavimo erdvė sukuria galimybę ignoruoti medžiagos konstrukcines savybes, jos vidines charakteristikas. Plona draperija tampa pagrindiniu formos paieškos elementu, tokiu būdu medžiaga leidžia architektui kurti koncepciją iš esmès prieštaraujančią medžiagos fizinèms galimybėms. Nereikètų ịsivaizduoti tokio formos kūrimo kaip nereikšmingo, nematerialaus. Skaitmeninejje erdvejje atskiriamos formos kūrimo ir jos materializavimo dimensijos, vèliau jos sujungiamos gamyboje, naudojant $\mathrm{CAD}^{9}$ ir $\mathrm{CAM}^{10}$ programas. Norint realizuoti skaitmeninejje erdvejje sumodeliuotą formą, reikalingas kompleksiškas medžiagos ir struktūros suvokimas. Integralus kompiuterinis modelis sujungia šiuos elementus sukurdamas galimybę novatoriškiems sprendimams. Skaitmeninèje erdvejje paviršius atlieka kitokị vaidmenį nei realybejje, dažnai jam skiriamas vaidmuo turi žymiai didesnę prasmę nei, tarkime, reprezentatyvumas. Kompiuteriniame formos paieškos procese, paviršius tampa pagrindiniu išraiškos elementu (Garcia 2006), „oda ir skeletas yra vienas ir tas pats elementas“ (Schumacher 2011).

Paviršiu įtaką architektūrinei formai galima apibūdinti trimis bruožais:

1. Paviršiai naudojami atskirti vizualiai dominuojančią architektūrinę formą nuo vidinès pastato sąrangos.

2. Paviršiai naudojami kaip sluoksnis, pabrèžti monumentalią pastato formą.

3. Fasadų tektoninė struktūra vizualiai suskaidoma hiperpaviršių pagalba.

1. Paviršiai, forma ir vidaus struktūra. Pradejus naudoti kompiuterinio projektavimo programas CAD ir kompiuteriu paremtas gamybos programas CAM $\mathrm{XX}$ a. pabaigoje, architektams atsirado daug galimybiu panaudoti sudètingesnius tūrinius elementus, modeliuoti neiprastas geometrines formas. Jas tapo lengviau ir pigiau realizuoti (Jodidio 2001). Nepaisant to, ne visuomet tikslinga komplikuoti funkcinę-planinę pastato struktūrą siekiant išorinio ekspresyvumo, tai galima igyvendinti išorinio apvalkalo pagalba. Tokiuose objektuose ypatingai išryškejja fasadiškumas, paviršiaus autonomija. Architektūrinè forma tampa nepriklausoma nuo konstrukcijos ir plastiški, išorę gaubiantys paviršiai apibrežia savarankišką statinio kontūrą.

Autonomiškas paviršiaus panaudojimas architektūrinèje raiškoje leidžia reaguoti i daugybę aplinkinių faktorių, tuo pačiu nesprendžiant funkcinių planinių klausimų: vizualus tūrio skaidymas, tarkime siekiant masteliškumo tam tikrame kontekste, harmoningų fasado proporcijų paieškos, idèjiniai, simboliniai, stilistiniai ar kiti kūrybiniai motyvai gali būti išsprendžiami manipuliuojant išorès plastika.

${ }^{9}$ Computer Aided Design (angl.) - Kompiuterinèmis programomis paremtas projektavimas.

${ }^{10}$ Computer Aided Manufacturing (angl.) - Kompiuterinėmis programomis paremta gamyba. 
Nerūdijančio plieno audinys puikiai veikia kaip paviršius, suminkštinantis grubias ir aštrias formas. Pačios medžiagos savybès leidžia kombinuoti blizgumą, ažūriškumą ir plastines galimybes. Olandų architekto Lars Spuybroek suprojektuotame polifunkciniame kultūriniame centre Lilyje, Prancūzijoje 2004 m. (130 pav.), šviesos - šešèliu judejjimas fasado paviršiumi, skulptūrinè plastika perteikianti judejimą, kūrybinį veržlumą, ekspresiją, atsispindi tik fasaduose (Quinn 2006). Pastato vidinè struktūra išlieka nuosaiki, funkciškai patogi. Pastato aptaki dinamika nekontrastuoja su aplinka ir ,tarsi gyvas organizmas isitvirtina aplinkoje“" (Stasiulis 2010).

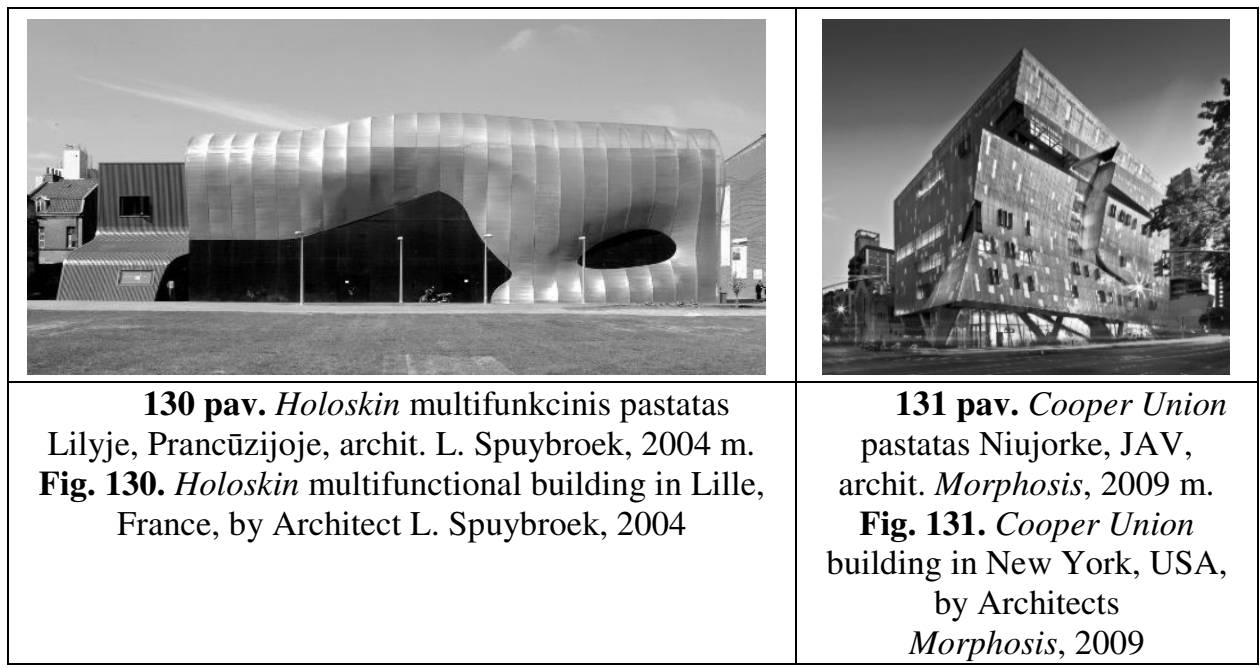

Meninès raiškos požiūriu panašus architektūrinis sprendimas realizuotas „Morphosis“ architektų kompanijos Niujorke, JAV 2009 m. pastatytame Cooper Union pastate (131 pav.). Tiesa, šiuo atveju dvigubas fasadas atlieka ne tik estetinę funkciją. Išorinis perforuoto metalo sluoksnis padeda kontroliuoti temperatūrinę aplinkos įtaką interjero erdvèms. Pasak autorių, ,metalinis pastato sluoksnis išorèje apgaubia pagrindinị stiklinị tūrị, tuo užtikrindamas temperatūros balansą, tačiau praleidžia šviesą, kas leidžia stebėti viduje vykstančius kūrybinius procesus. Skulptūriška Cooper Union pastato išraiška pakelia viso kvartalo architektūrinę vertę, reaguoja ị aplinkinį užstatymą“. Banguojantis, suskaldytas fasadas tūriškai susmulkinamas ị tam kvartalui būdingą mastelị. Šiuo atveju pastato apvalkalas tarnauja kaip vienas pagrindinių architektūrinès estetikos formantų, diktuojantis proporcijas, įtakojančias masyvaus tūrio kontekstualumą.

2. Paviršių daugiasluoksniškumas ir monumentalumas. Autonomiški pastato paviršiai gali būti naudojami ir siekiant architektūrinès formos monumentalumo, norint pabrèžti vientisą statinio formą. Tam naudojamos permatomos fasadų apdailos medžiagos, dažniausiai stiklas arba ažūras, sukuriant architektūrinès formos daugiasluoksniškumą. Išorinis pastato kontūras, tokiu atveju, papildo 
vidinę struktūrą, tai gali sukurti išskirtinai dekoratyvumo įspūdị, tačiau taip pat ir pabrèžti formos vientisumą.

Tokie architektūriniai sprendimai igyvendinti F. Gehry administracinio pastato fasade Prahoje, Čekijoje (1992-1996 m.) (132 pav.), ir LAB architektu suprojektuotame visuomeniniame pastate Melburne, Australijoje (2002 m.) (133 pav.). Šiuose pastatuose išorinis, peršviečiamas sluoksnis sukuria viduje esančios struktūros monumentalumą. Tarkime, F. Gehry „šokančiame pastate“ stiklinio tūrio kontūras pabrèžia vientisą fasado plokštumą, nors viduje esantis tūris suskaldytas langų ertmėmis ir perdangų horizontalèmis. Stiklinio apvalkalo dèka, peršviečiamas ir medžiagiškai atskirtas korpusas neišsiskiria iš monumentalios, skulptūriškai banguojančios pastato plastikos. LAB architektų pastato fragmente stiklo plokštuma apvelka ažūinę konstrukciją, o stiklų dalijimas tik pabrèžia dinamišką, suskilusio fasado metaforą.

Ivairaus pobūdžio pastato apvalkalai šiuolaikinèje architektūroje naudojami ne tik estetiniais sumetimais. Tvarūs, energiją taupantys sprendimai, skirti maksimaliai išnaudoti saulès energiją gali pasitarnauti ir pastato architektūrinei raiškai. Tuo pasižymi Norvegijos architektų „Snohetta“ 2009 m. suprojektuotas Karaliaus Abdulazizo žinių ir kultūros centras Dhahrane, Saudo Arabijoje (134 pav.). Švelnių kontūrų statinių komplekso tūrinè išraiška susilieja su aplinka. Dykumoje išdèstyti pastatai primena vejjyje nugludintus akmenis, besiremiančius tarpusavyje. Kiekvienas tūris yra atskiras funkcinis korpusas: biblioteka, ekspozicijų centras, koncertų ir pasirodymų salès ir kt. Visgi, architektai susidūrè su problema. Siekiant monumentalumo, kuris reprezentuojamas pastato tūrinejje išraiškoje, reikejjo išspręsti ir apšviestumo problemas, tuo pačiu ir apsaugoti pastato vidines erdves nuo per didelio saulès kaitros poveikio. Akivaizdus ir logiškas sprendimas tokiu atveju - transformuojamas fasadas. Stikliniai pastato tūriai apvyniojami lanksčiais $67 \mathrm{~mm}$ skersmens nerūdijančio plieno vamzdeliais, kurie sutekia šešèli ir ventiliaciją vidinèms erdvèms, o taip pat surenka saulès energiją. Tose vietose, kuriose reikia daugiau šviesos, vamzdeliai suplonèja, išsaugodami raštą, tačiau praleisdami šviesą. Kiekvienas korpusas, tos pačios medžiagos pagalba, gauna skirtingą raštą, priklausantị nuo pačio tūrio geometrinių charakteristiku, iejjimo angos formos ir nuo konkrečios vietos, kurioje pradedami vynioti vamzdeliai. Visi tūriai tampa skirtingi, turintys tarsi savo piršto antspaudą (135 pav.). Kadangi pastato išorinis sluoksnis ịkaista iki maždaug $80^{\circ} \mathrm{C}$, karščio bangos, kylančios aukštyn suformuoja banguojančią aurą aplink pagrindinius pastato tūrius (Thorsen 2010).

Iš pastarojo pavyzdžio matome, jog pastato apvalkalas, kaip išraiškos elementas, gali būti vienas pagrindinių architektūrinès raiškos konceptų, formuojantis pastato išskirtinumą ir atpažįstamumą, tuo pačiu atlikdamas daugybę techninių funkcijų. Šiuo konkrečiu atveju, norejus pabrěžti dominuojančių formų masyvumą, daugiasluoksniškumas tapo monumentalumo priežastimi. Nepaisant 
to, jog išorinis sluoksnis vietomis atsiveria, o kitur susiglaudžia, praleisdamas tai daugiau, tai mažiau šviesos, struktūrinis išorès raštas išlieka, pabrèždamas masyvią, nepajudinamą gamtos formas atkartojančių tūrių kompoziciją.

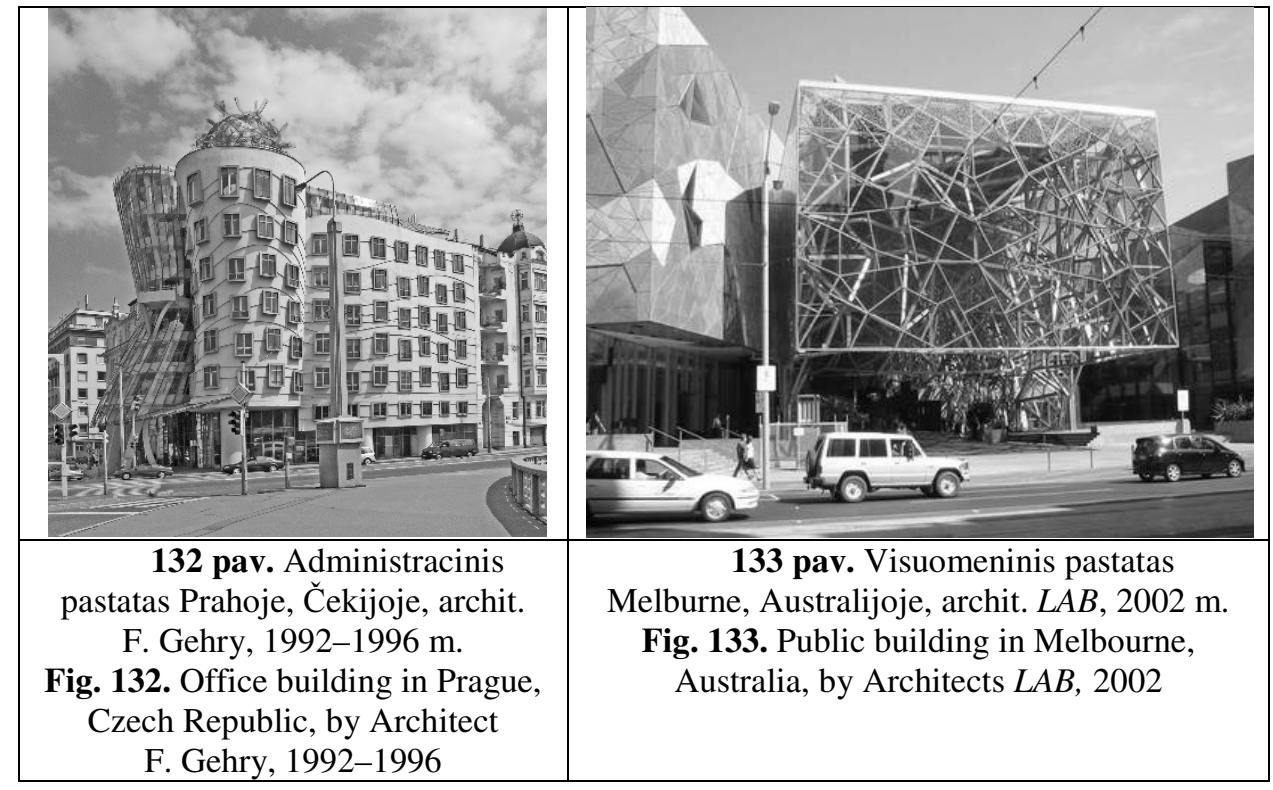

3. Paviršiu dualumas. Paviršių dualumo architektūroje išraiška hiperpaviršiai. Hiperpaviršius - tai architektūrinès formos būklè, kylanti iš dažnai viena kitai priešingų sričių, idèjos ir materijos susiliejimo i neišskaidomus sudètinius darinius, kurie sukuria visomis kryptimis veikiančias išcentrines būsenas. S. Perrella terminą „hiperpaviršius“ ivardija kaip būdus, kuriais „,<..> reprezentuojančio vaizdo ir formos sritys yra atitinkamai pertvarkomos ir išskiriamos i naują vaizdo ir formų sąsają. Hiperpaviršiai yra suformuotos, imanentinès topologijos, sudarančios nedialektines vaizdo ir formos aplinkas, kuriose absorbuojamas intersubjektiškumas vèl iškyla tik pats iš savęs. Hiperpaviršius deklaruoja produktyvų kitoniškumą, kuris tradiciškai neapibrežiamas, tačiau tuo pat metu yra kilęs iš tradicinès kultūros principų“ (Perella 1998). Dèl savo dualumo, paviršius itakoja pastato struktūrą, vizualiai veikia tektoninę formą, tuo pakeičia architektūrinès formos suvokimą. Viena pagrindinių priemonių formuoti hiperpaviršius - medijos.

Medijų pritaikymas fasadų plokštumoms nèra naujiena užsienio architektūroje, tiesiog pastaraji dešimtmetị ypatingai jaučiamas susidomèjimas tokiomis išraiškos priemonėmis. Dinamiški fasadų elementai verčia architektus domètis fasado detaliu kintančia ritmika, sekomis, eiliškumu. Fasadai tampa aktyvūs laiko dimensijoje. Po to, kuoment Graz mieste, Austrijoje 2003-aisiais meno, architektūros ir technologijų studija Realities:united ant meno centro 
fasado (arch. P. Cook, C. Fournier, 2003 m.) įrengè media fasadą BIX (136 pav.), juos turbūt pelnytai galima būtų laikyti šios srities instaliacijų pradininkais.

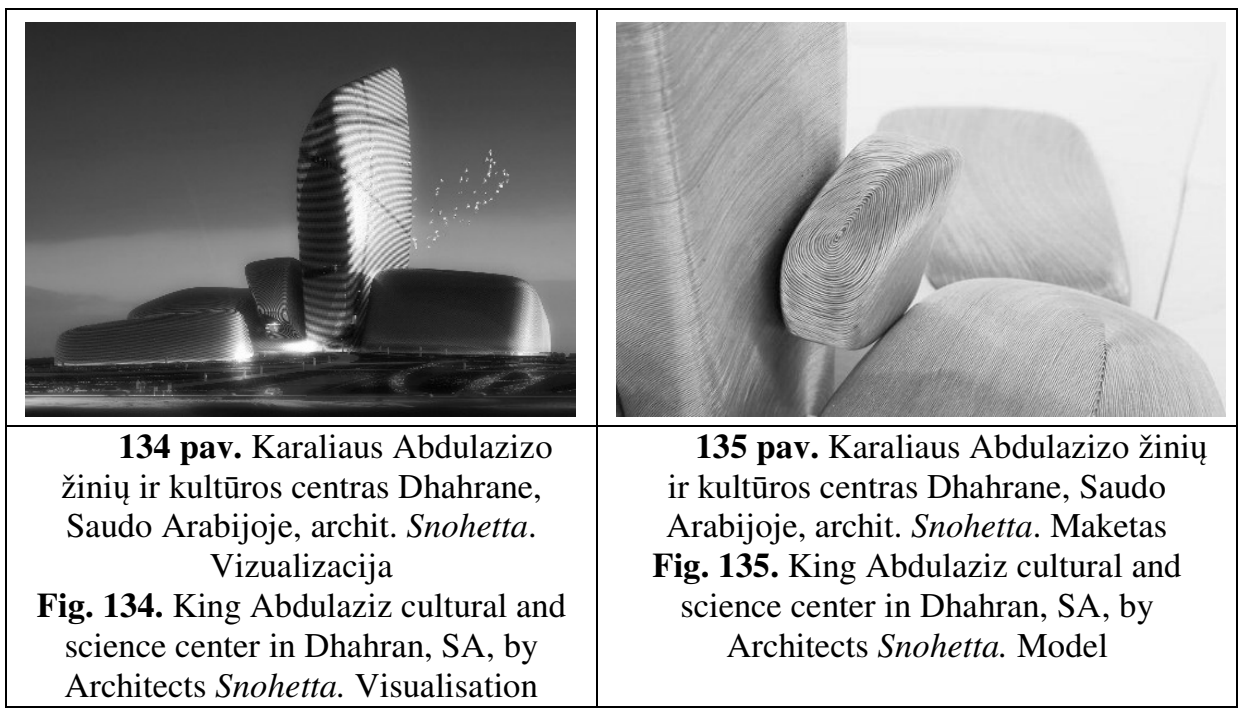

Medijų naudojimas architektūroje leidžia siekti ne tik estetinių tikslų. Tai, kas viduje, šiuolaikinių technologijų pagalba gali būti matoma iš išorès. Modernistų bandymai apjungti vidaus ir išorès erdves buvo daugiau idèjiniai, architektų Rogers ir Piano Pompidou centras Paryžiuje - tarsi šaržuotas bandymas ,išversti““ pastatą iš vidaus i i išorę. Meno centras Graz mieste atspindi tą pačią filosofiją, tačiau igyvendina tai šiuolaikinių technologiju pagalba. Be minèto objekto Austrijoje, panašios instaliacijos pristatytos žiūrovams Potsdamo aikštèje Berlyne, Vokietijoje (2005 m.), Singapūre, (2008 m.) (137 pav.) ir kt.

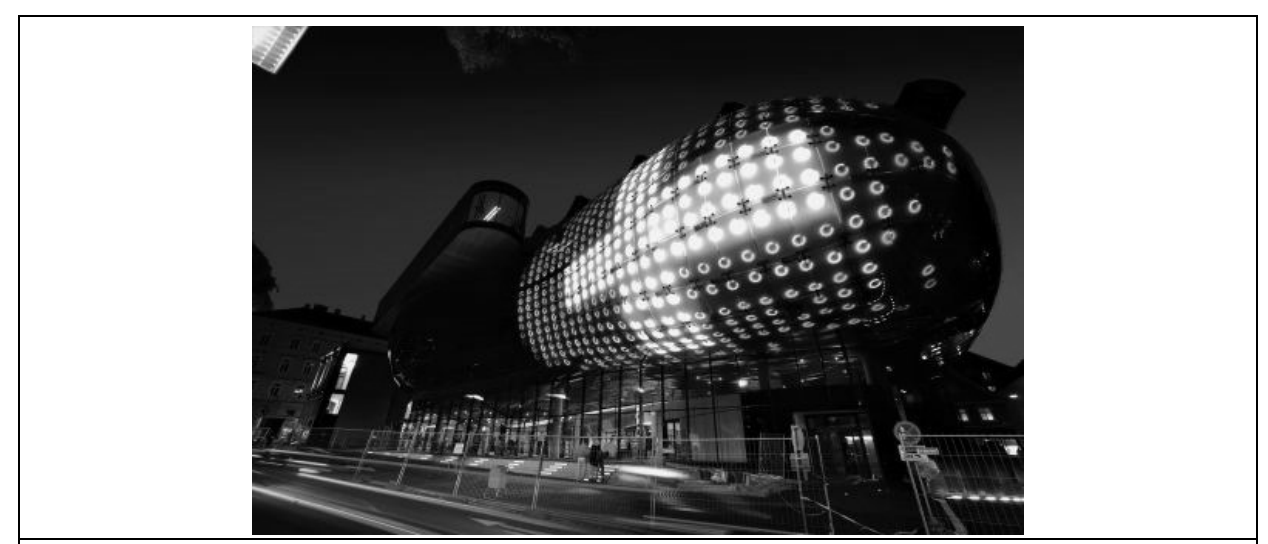

136 pav. Medijų instaliacija $B I X$, Gracas, Austrija, aut. Realities:united, $2003 \mathrm{~m}$. Fig. 136. Media installation BIX, in Graz, Austria, Authors Realities:united, 2003 


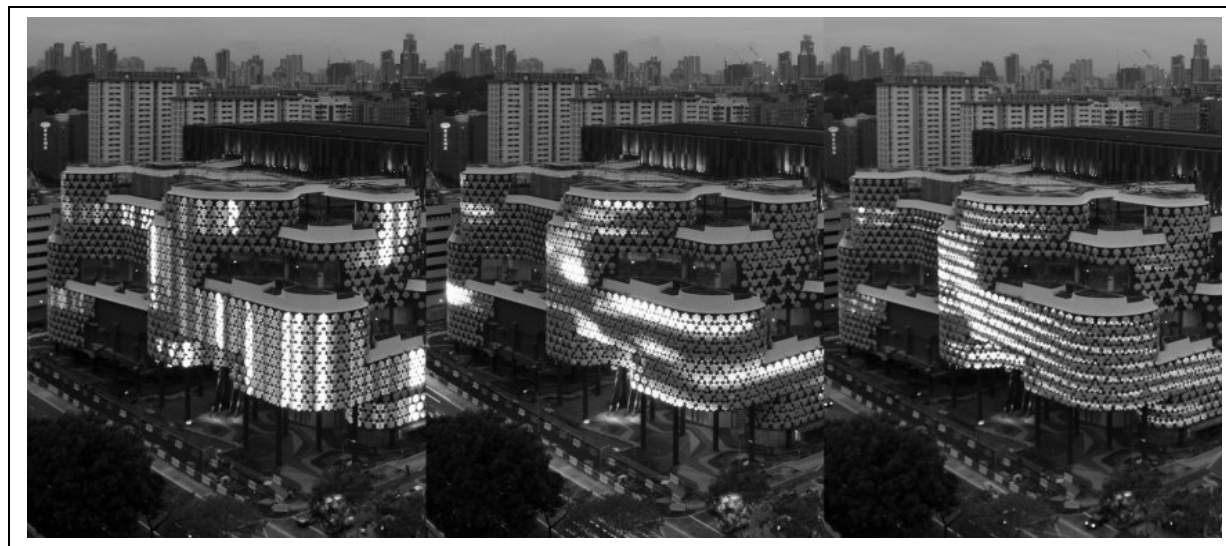

137 pav. Media instaliacija Crystal Mesh, Singapūras, aut. Realities:united, $2009 \mathrm{~m}$.

Fig. 137. Media installation Chrystal Mesh, Singhapore, Authors Realities:united 2009.

Pastaraisiais metais, anksčiau naudotas reguliarus šviečiančių elementu (galime vadinti juos pikseliais, kadangi jų pagalba sudaromas didesnis vaizdas) tinklas, pakeistas įvairesnių elementų sekomis. Tai leidžia pateikti įvairesni pikselių išdèstymą, tuo pačiu ir ịdomesnę media fasadų raišką. Pateiktame pavyzdyje pikseliai primena ịvairaus dydžio kristalus, kuriančius ne tik media vaizdą naktį, tačiau ir turinčius specifinę tekstūrą, kuri matoma dieną. Ši struktūra veikia kaip ventiliuojamas fasadas ir kaip miesto apšvietimas. Žmogaus santykis su tokio pobūdžio pastatu nevienareikšmiškas. Ne tik dèl to, kad fasadas nuolat kinta. Aplink esanti erdvė užpildoma skaitmeniniu media turiniu (Croci 2010).

Prie vizualiai ardančių pastato struktūrą paviršiaus apraišku galima priskirti ir interaktyvius pastatus. Interaktyvūs pastatai reaguoja ị aplinkos veiksnius (vejją, šviesą, temperatūrą, etc.) taip pat ị žmonių veiklą. Nagrinejjant paviršių itaką pastato architektūrinei išraiškai, ypatingai įdomūs pavyzdžiai, kuomet pastato eksploatacijos eigoje atsiranda paviršiaus autonomija. Kitaip tariant, pastato architektūrinè išraiška yra vienokia, o panaudojus papildomą paviršių - radikaliai skiriasi. Kaip pavyzdi galima pateikti instaliaciją sukurtą Minesotos Universiteto tyrimu centro laboratorijai. Menininkas Ann Hamilton, bendradarbiaudamas su „Small Design Firm“ ir „EAR Design Studio“ pasiūlè dinamišką LED šviestuvų pagrindu sukurtą instaliaciją, perteikiančią vidaus procesus ị išorę. Pasiūlytas sprendimas sujungia daugybę sistemų, tarp kurių ir daugybę pastato viduje esančiu judesio daviklių. Programinè įranga apdoroja gautus duomenis ir perteikia ant fasado pageidaujamais būdais. Tokiu būdu pastato paviršius tampa aktyvus, reaguojantis i viduje vykstančius pokyčius, o tuo pačiu ir dinamiškas bei nenuspejjamas (Small 2006). Dominuojančios langų plokštumų vertikalès suskaidomos šviečiančiomis horizontalèmis, kurios pulsuoja kintant apšvietimo intensyvumui ir spalvoms, taip tapdamos svarbiausiais pastato akcentais. 
Šiuolaikinių medijų kūrejų darbuose pastebimas architektūrinių elementų (fasadu, vidaus erdvių) naudojimas vaizdinèse instaliacijose, projekcijose. Menininkai kuria instaliacijas, pritaikytas konkrečiai erdvei, plokštumai, sujungdami esamus architektūros elementus (langų ertmes, balkonus, nišas) paversdami juos vaizdinès projekcijos dalimi. Žaidimas fasado elementais, šviesos ir šešèlių kontrastais, spalvų panaudojimas panaikina esamą, projekto autoriaus sukurtą kompoziciją. $2010 \mathrm{~m}$. buvo pristatyta vaizdo projekcija „555 KUBIK“ (D. Rossa, „Urbanscreen“) (138 pav.) ant meno centro fasado Hamburge, Vokietijoje (arch. O. M. Ungers 1995 m.). Šios projekcijos pagalba stengtasi suardyti griežtą pastato architektūrinę išraišką. Monumentalioje fasado plokštumoje rodomos interpretacijos, geometrinè estetika perteikiama per judesį. Panašių sprendimų galima aptikti ir kitų panašaus pobūdžio menininkų darbuose.

Elektronine paradigma yra didelis iššūkis architektūrai, nes ji kuria realybę per medijas ir simuliacijas, labiau vertina vaizdinius nei realybę. Medija sukuria dviprasmybę to, ką ir kaip mes matome. Anksčiau architektūroje tokių klausimų nereikejo kelti, kadangi nuo XV a., kuomet buvo suvokta vizualinès perspektyvos esmé, architektūroje dominavo elementarus matymas. Architektūra priima regèjimą kaip natūralų kūrybos ir vertinimo procesą, tačiau būtent tą ,natūralumą“ kvestionuoja elektroninè paradigma. Kinta stebètojo (subjekto) ir objekto santykis. Tradicinès architektūros struktūra paremta tam tikrų kompozicinių elementų išdèstymu vienokia ar kitokia tvarka, sukuriant subjektui tam tikrą scenarijų. Medijos kuria kitokią architektūrinę raišką.

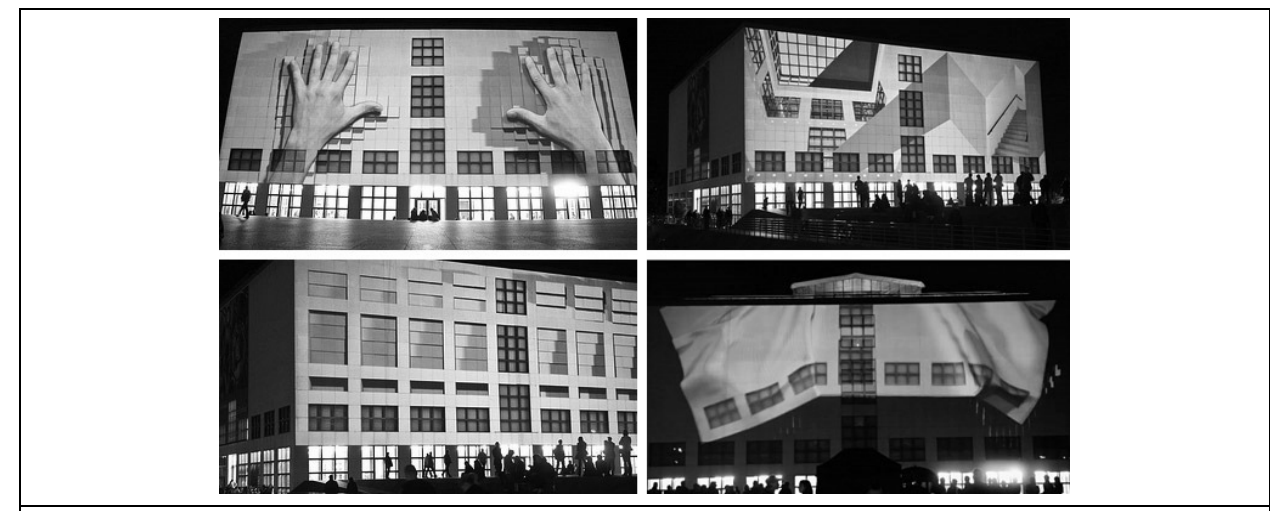

138 pav. Media instaliacija 555 Kubik, Hamburgas, Vokietija, aut. D. Rossa, 2010 m.

Fig. 138. Media installation 555 Kubik, in Hamburg, Germany, by D. Rossa, 2010

Šiuolaikinei architektūrai būdinga kompiuterizacija pasireiškia ne tik formų analizès, paieškos ar tiesiog projektavimo etape. „Siuolaikiniai pastatai kompleksiškas mechanizmas ne tik ịvairių modernių formų ịvaldymo požiūriu, o dažnai apjungiantis visą pastato valdymo mechanizmą, elektros, oro cirkuliacijos, signalizacijos, priešgaisrinius mechanizmus. Paradoksalu, tačiau šiuolaikiniuose 
pastatuose didelis informacijos srautas naudojamas tam, kad būtų paprasčiau jais naudotis“ (Tzionis 1992). Taigi, ar estetiniais, ar tik informaciniais tikslais pastatuose naudojamos medijos, hiperpaviršiai, ar kitokia 4D išraiška taip pat prisideda prie šiuolaikinès architektūros kompleksiškumo. Pastaruoju metu ryškejjančios tendencijos paverčia architektūrą tarpdisciplininiu objektu.

Autonominė paviršių raiška šiuolaikinèje Lietuvos architektūroje. Lietuvos architektūroje, išskyrus slick-tech raišką ir pavienius atvejus, daugiau koncentruojamasi ị tūrio formavimą, nuosaikų vidaus erdvių ir tektoninès pastato sąrangos ryšị, paviršių estetiką paliekant antrame plane. Tai galima būtų sieti su ekonominiais motyvais, kadangi paviršius, kaip autonomiška pastato išraiškos priemonè, daugumoje atvejų tarnauja išskirtinai estetiniams tikslams. Vis dèlto, didejjant reprezentatyvumo poreikiui, dažniausiai visuomeniniuose pastatuose, paviršiai vis dažniau naudojami architektūrinès formos kūrime.

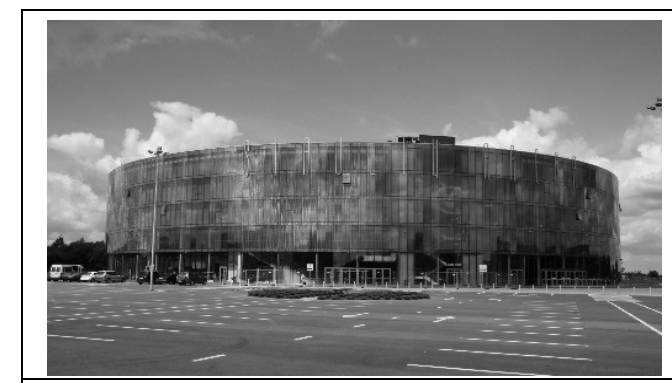

139 pav. Aukštabalio multifunkcinis kompleksas Šiauliuose, archit. E. Miliūnas, A. Bublys, G. Balčytis ir kt., $2007 \mathrm{~m}$. Fig. 139. Aukštabalis multifunctional complex in Šiauliai, by Architects

E. Miliūnas, A. Bublys, G. Balčytis and others, 2007

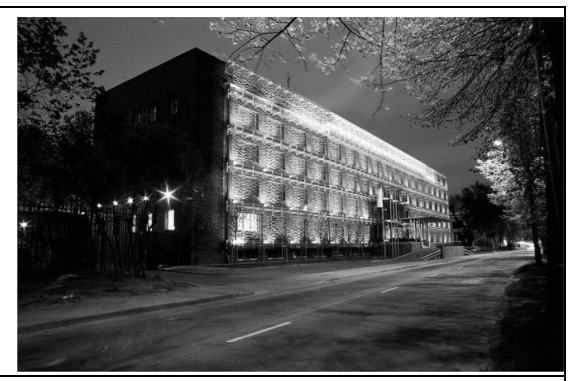

140 pav. Administracinis

Lietuvos Energijos pastatas Vilniuje, archit. K. Pempè, A. Pliučas, $2003 \mathrm{~m}$.

Fig. 140. Lietuvos Energija office building in Vilnius, by Architects K. Pempè and A. Pliučas, 2003

Aukštabalio daugiafunkcinis kompleksas Šiauliuose (archit. E. Miliūnas, A. Bublys, G. Balčytis ir kt. 2007 m.) (139 pav.), paviršių raiškos architektūrinejje formoje aspektu reikšmingas dèl fasado apdailai panaudoto holografinio stiklo dualumo. Cilindro formos areną apjuosęs stiklinis paviršius atlieka ne tik utilitarią išorinès atitvaros funkciją, kadangi holografinio stiklo savybès suteikia objektui savybę vizualiai keistis, priklausomai nuo paros meto. Šilti, dienos metu vyraujantys atspalviai pastatą optiškai didina, šalti, vakariniai - mažina, šviesesni atspalviai paryškina objekto formą, tamsesni - niveliuoja. Ryškiai šviečiant saulei pastatas igauna raudonų, žalių, mėlynų atspalvių. Šiuo atveju pirminè geometrinè forma, cilindras, veikiant hiperpaviršiui praranda sunkumą, stabilumą, pastatas igauna lengvumo ir nenuspejamumo įspūdị.

Šiek tiek kitokia paviršiaus itaka architektūrinei formai pasižymi bendrovès „Lietuvos energija“ būstinè Vilniuje (archit. K. Pempè, A. Pliučas 2003 m.) 
(140 pav.). Sovietinis pastatas apdailintas tamsiomis klinkerio plytelèmis, pabrèžiančiomis sunkų, nepajudinamą, monumentalų tūrị. Išsaugotas tvarkingas langų ritmas, vienodas langų dalijimas, bendra fasado simetrija paryškinta naujai suprojektuotu iejjimo stogeliu. Siekiant sukurti dinamiškumo ịspūdi, i priekị iškeltas antras, stiklinis fasadas su šilkografijos elementais. Pastarieji dienos metu matomi tik iš arti, todèl dominuoja lygi, permatoma stiklo plokštuma atspindinti aplinką ir pabrèžianti bendrą pastato monumentalumą. Naktį, laužytų linijų banguojantis šilkografijos piešinys apšviečiamas fasado paviršiuje imontuota apšvietimo sistema, pakeičiančia statišką ir sunkią pastato formą i ažūrišką ir dinamišką (Almonaitytè-Navickienè 2006).

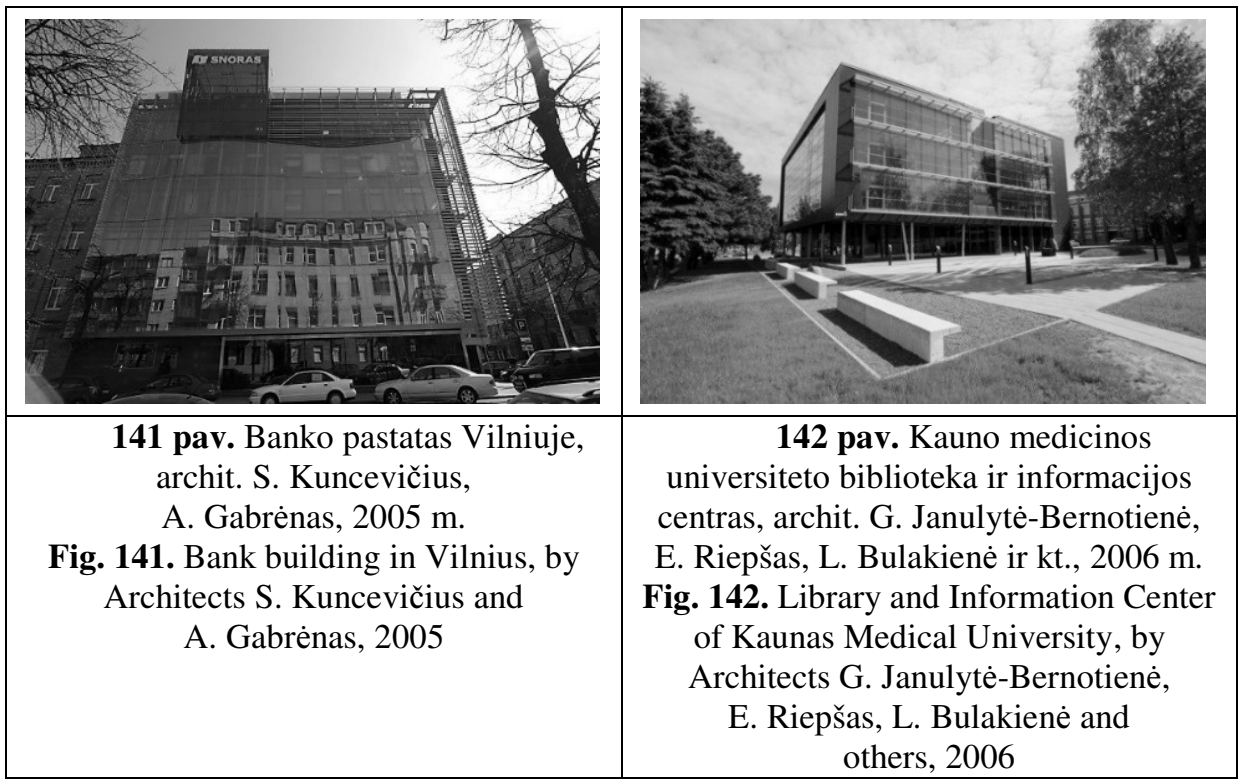

Iš pirmo žvilgsnio analogiškas daugiasluoksnių paviršių panaudojimo rekonstrukcijoje pavyzdys yra banko pastate Vivulskio g. Vilniuje (archit. S. Kuncevičius, A. Gabrènas 2005 m.) (141 pav.), tačiau nepaisant panašaus konstrukcinio ir medžiagiško sprendimo, architektūrinès formos požiūriu, paviršiaus panaudojimas fundamentaliai skiriasi. Skirtingai nei „Lietuvos energijos“" pastate, čia paviršius naudojamas kaip nepriklausomas elementas naujos formos modeliavimui. Ant pastato atsiradę tūriniai elementai yra labiau naujo, stiklinio tūrio akcentai, neturintys nieko bendro su senuoju pastatu. Naujas paviršius neatkartoja senosios pastato struktūros, vietomis banguoja, kai kur yra perskirtas ažūro, o naktį apšvietimas taip pat koncentruojamas paryškinti išorinị fasadą. Banko pastate paviršius modeliuoja formą, o „Lietuvos energijos“ pastate veikia daugiasluoksniškai, pabrèžia esamą tūrị ir architektūrinei formai prideda dekoratyvumo. 
Kauno medicinos universiteto biblioteka ir informacijos centras (archit. G. Janulytė-Bernotienè, E. Riepšas, L. Bulakienè ir kt., 2006 m.) (142 pav.) vertinant tūrinę - funkcinę schemą artimesnis modernistinei architektūros tradicijai, nors savo masyvumu ir gali turèti aliuzijų i minimalizmą (AlmonaitytèNavickienè 2006). Vizualiai sunkus pastato tūris pakilęs nuo žemès, paremtas metalinėmis kolonomis, stiklinè, atspindinti aplinką pirmo aukšto dalis igilinta, formuojanti iejjimo trauką. I monumentalų, plytų mūro tūri i ikirstas erkeris pabrěžia pastato vertikalinius ryšius o taip pat suskaido tūrị vizualiai. Pasvirusi stiklinès dalies kryptis kompoziciškai atsikartojama tiek fasaduose, tiek iracionaliame kolonų tinkle, samoningai paneigia pretenzijas i minimalistinę raišką. Interjeruose daugiau matomas atviru konstrukcijų, metalo ir stiklo žaismas artimesnis high-tech ir slick-tech architektūrai. Akị traukia dar vienas architektūrinis elementas - dvigubas fasadas. Šiuo atveju pastato raiškos jis nepraturtina, veikia daugiau kaip paviršiaus inžinerinis elementas. Autorių teigimu, jis skirtas reguliuoti patalpų mikroklimatą atspindint saulès šviesą. Tam tikru kampu pasukti stiklo elementai praturtina pastato raišką blyksèdami vaivorykštès spalvomis, tačiau neformuoja pastato atpažistamumo, o taip pat kontrastuoja su pasvirusiomis kolonomis, erkeriu, langų ertmėmis.

\subsection{Kompleksiška postmodernizmo raiška. Istorizmas, stilizacija ir metafora}

Pirmieji kompleksiškos postmodernizmo raiškos bruožai Lietuvos architektūroje aptinkami tik devintajame XX a. dešimtmetyje, nors pasaulineje architektūroje postmodernizmas pastebimas dar septintojo dešimtmečio pradžioje. Kaip teigia K. Frampton, modernizmą kaip stilių užbaigia postmodernizmas - globali prieštara moderniajai formai, apeliuojanti ị klasikinị stilių, tačiau labiau orientuota i i ispūdị ir ịvaizdị, nei i turinị (Frampton 2007). Postmodernizmas būdamas modernistinès architektūros tąsa, savotiškas stiliaus manierizmas (Mačiulis 1996) pasižymintis pliuralizmu (Jencks 2011), ivvairių idejjų sintezèmis, kilo iš nepasitenkinimo modernistinès architektūros nelankstumu, formalistiniu požiūriu. Kitokios architektūros poreikis pastebimas to meto straipsniuose ir atsiliepimuose, išdèstančiuose platų moderniosios architektūros ideologinių problemų spektrą. R. Banham (Banham 2008b) straipsnyje „The Italian Retreat from Modern Architecture“ (1959 m.) ieško nacionalinio charakterio moderniojoje Italijos architektūroje, S. Anderson (Anderson 2008) straipsnyje „Architecture and Tradition. That Isn't „Trad Dad“““(1964 m.) nagrinejja tradiciju ir progreso (taip pat ir architektūrinio) santyki, A. Rossi (Rossi 2008) straipsnyje „The Architecture of the City“ (1966 m.) teigia, jog šiuolaikinis modernistinis miestas naikina nacionalini charakteri, tampa „,erdve“, o ne „vieta“. E. N. Rogers 
(Rogers 2008) straipsnyje ,The Evoloution of Architecture : An Answer to the Caretaker of Frigidaires" (1959 m.) teigia, jog architektūra turi evoliucionuoti ir keistis, bei prisitaikyti prie kintančių poreikių, A. van Eyck (van Eyck 2008) straipsnyje „Is Architecture Going to Reconcile Basic Values?“(1959 m.) pažymi vertybinius architektūros pokyčius, unikalumo siekį. J. Rykwert (Rykwert 2008) straipsnyje „Meaning and Building“ (1960 m.) ir T. Maldonado (Maldonado 2008) „Notes on Communication” (1962 m.) pastebi augančią ženklų ir simbolių kalbą archiektūrinèje raiškoje. C. Rowe ir R. Slutzky (Rowe 2008b) straipsnyje ,Transparency: Literal and Phenomenal“" (1963 m.) teigia, jog pastato forma turètuc būti atskirta nuo funkcijos, o Ch. Norberg-Schulz (NorbergSchulz 2008) straipsnyje ,Intentions in Architecture” (1963 m.) apskritai, architektūrinę formą traktuoja kaip atskirą, juslinę dimensiją, nepriklausančią nuo konkrečios pastato formos.

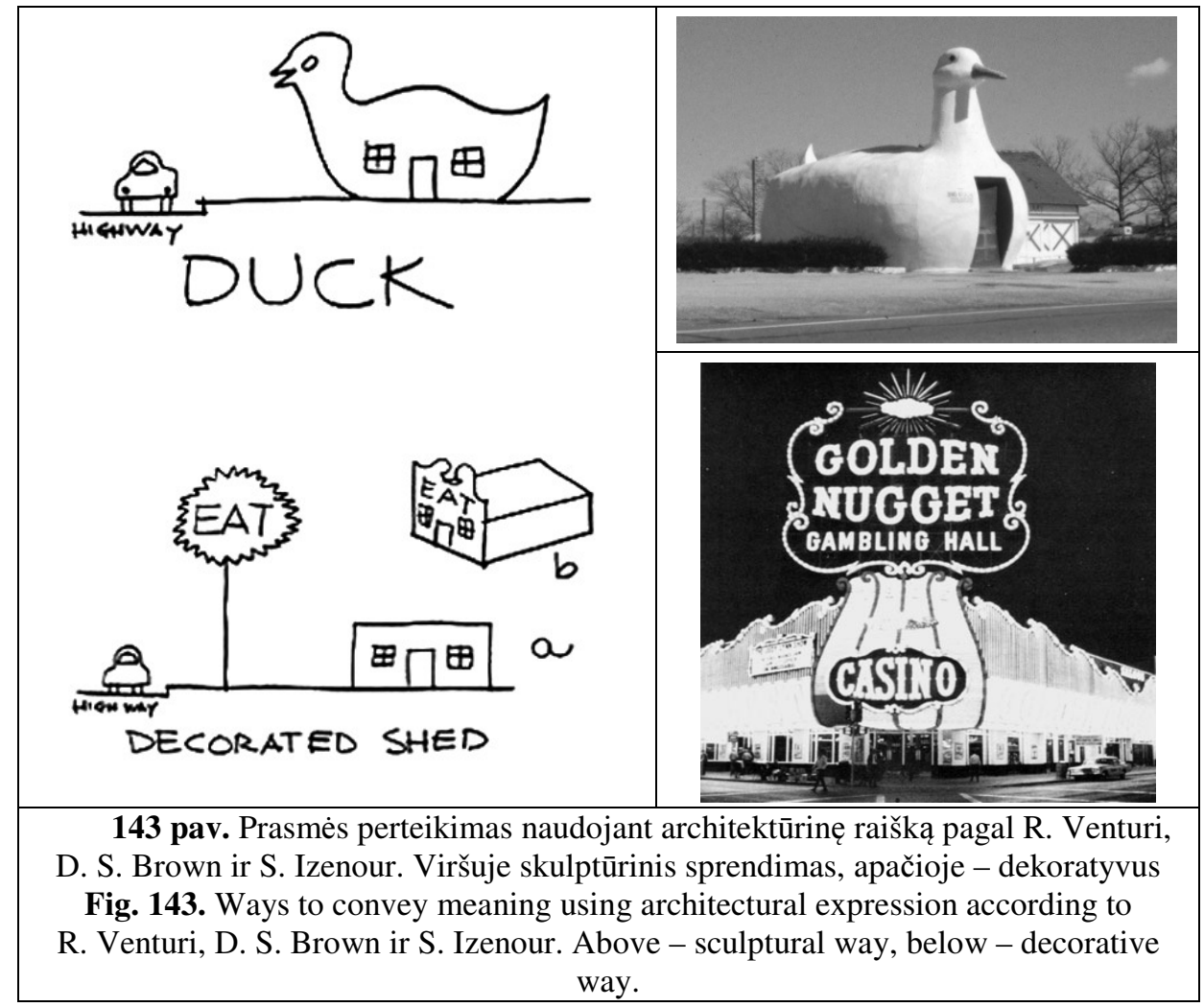

Vèlesniuose šaltiniuose modernizmo kritika virsta naujų idejų paieškomis, stengiamasi įžvelgti įtakų įvairovę, pliuralizmo architektūroje pranašumus, pastebimas siekis apibrèžti naujosios architektūrinės raiškos kontūrus. Aiškų sieki ịtvirtinti regionini charakteri architektūroje deklaruoja Ch. Norberg-Schulz 
(Norberg-Schulz 1971) knygoje „Existence, Space and Architecture“ (1971 m.), kurioje pastebima didejanti jau anksčiau minètos „vietos“, o ne „erdvès“ koncepcijos architektūroje svarba. Colquhoun (1985) straipsnyje „Historicism and the Limits of Semiology“ (1972 m.) nagrineja išaugusią istorizmo svarbą tuometineje architektūroje, Ch. Jencks knygoje „The Language of Post-Modern Architecture“ (1977 m.) nagrineja itakas tuometinei postmoderniajai architektūrai, tarp kurių ne tik socialinès, bet ir filosofinès, o J. P. Bonta tyrime „Architecture and its Interpretation“ (Bonta 1977) ir H. Hertzberger (Hertzberger 2008) straipsnyje „Homework for More Hospitable Form“ (1973 m.) išskiria interpretacijos svarbą, kaip vieną pagrindinių architektūros kitimo ir progreso sąlygų. Pliuralizmas urbanistikoje nagrinejamas H. Fathy (1973) knygoje „Architecture for the Poor“, kurioje aprašomi miestu planavimo eksperimentai, naudojant modernistinius planavimo principus ir vietinę, tradicinę architektūrinę raišką, o C. Rowe ir F. Koetter (Rowe 2008a) tyrime „Collage City“ (1975 m.) nagrinèja kontekstualumą, vietinị charakterị, natūralią, multikultūrinę urbanistinę raidą.

Vieną pirmujų bandymų apibrèžti kompleksišką postmodernizmo architektūros meninių priemonių raišką ir atskirti ją nuo modernistinès, galime laikyti Robert Venturi (1966) „Complexity and Contradiction in Architecture“. Pradėdamas nuo istorinès baroko architektūros, R. Venturi apima Le Corbusier ir M. van der Rohe funkcionalizmą, A. Alto modernizmą, palyginimui įtraukdamas keletą savo paties tuometinių darbų. „Complexity and Contradiction in Architecture" yra savotiškas postmodernizmo manifestas, atspindintis pakitusią architekto rolę, nagrinejjantis kūrèjo santykį su pačiu savimi, profesija ir sociumu. R. Venturi teigia:

1. Architektas privalo projektuoti atsižvelgdamas i kliento programos sudètingumą ir kompleksiškumą. Sudėtingos, kompleksiškos programos šiuolaikinių socialinių ir ekonominių pokyčių rezultatas. Modernistinei architektūrai labiau tinka vienos funkcijos pastatai, taip pat tie, kuriuos projektuojant galima naudoti modulines sistemas, šių laikų poreikio tai nebetenkina.

2. Nepaisant deklaracijų jog forma seka funkciją, taip niekada nebuvo ir nèra jokių priežasčių kodèl reikètų to siekti. Jeigu įvairūs dekoratyviniai elementai yra atmetami modernistinès ideologijos, ir laikomi nereikalingais ir apsunkinančiais formos grynumą, tuomet pati ideologija neturètų būti laikoma kaip estetiką formuojantis faktorius, nes pati ideologija apsunkina kūrybos procesą.

3. Architektūrinè kalba turi daug reikšmių, yra polisemantinè. Būdai, kuriais architektūra perteikia prasmę, gali nebūtinai sutapti su forma, struktūra ar programa, kuria ji remiasi. Tai gali būti skulptūrinis sprendimas (kur erdvès, struktūra ir funkcija apjungiamos viena simboline forma), ir dekoratyvus sprendimas (kur erdvès, struktūra ir funkcija remiasi modernizmo projektavimo 
principais, o simboliniai motyvai perteikiami atskirai - ornamentika ir stilizacijomis). Tai R. Venturi, D. S. Brown ir S. Izenour ironiškai pavadino atitinkamai „The Duck“11 ir „Decorated Shed“12 (143 pav.).

4. Architektas turi ieškoti neaiškių, sudètingų ir prieštaringų prasmių, kurios būdingos šiuolaikiniam pasauliui. Todèl šiuolaikinè architektūra ir yra realistinè. Ji naudoja visiem suprantamas, iprastines priemones tam, kad sukurtų kažką neiprasto.

5. Vietoje modernistinès vienalytès erdvès, postmodernizme naudojami ịlinkiai ir tūrio fragmentacija, o tai formuoja skaidytą erdvès konceptą. Sienos yra traktuojamos kaip pertvaros, ant kurių galima prilipdyti ornamentą. Fasadai formuoja atpažistamos vietos vaizdą.

Šie kūrybos principai padèjo autoriui suformuluoti kai kuriuos kompleksiškos postmodernistinès architektūros meninès raiškos bruožus (2 lentelè). Siekiant pabrezžti skirtumus, autorius lygina funkcionalią modernistinę ir kompleksišką postmodernistinę raišką.

Ch. Jencks architektūrinio stiliaus (modernizmo, vèlyvojo modernizmo ir postmodernizmo) meninę raišką skirsto ị tris pagrindinius segmentus: ideologiją, stilistiką ir kūrybos idèjas. Stilistiniai raiškos bruožai apibūdinantys postmodernizmą: mišri raiška, kompleksiškumas, besikeičianti erdvè, iprastos ir tradicinès formos, eklektika, pabrěžta semiotika, turinio ir semantikos svarba prieš funkciją, organiškumas ir ornamentika, reprezentatyvumas, metaforiškumas, istorizmas, humoras, simbolika.

R. Stern (1980) postmodernistinès architektūros bruožus nustato padalindamas postmodernistus į dvi grupes. Tuos, kurie nepripažista modernizmo itakos, ir sieja save su humanizmo tradicijomis, ir tuos, kurie tęsia modernistines tradicijas, tačiau praturtina jas laužydami dogmatines normas, kurios ir laikomos moderniosios architektūros žlugimo priežastimi. R. Stern teigia, jog postmodernistai naudoja meną, kaip įrankị reflektuoti kasdieninius ịvykius o taip pat juos interpretuoti. Postmodernizmas atpasakoja socialines realijas, todèl yra reprezentatyvus, o ne konceptualus ar abstraktus. Postmodernizmo santykis su istorija nèra tiesioginis, o daugiau paremtas interpretacijomis, ir todèl, jog nèra ideologinių stilių formuojančių nuostatų (kaip pavyzdžiui modernizme), galima adaptuoti tam tikrus kūrybos principus, kurie buvo nepelnytai nenaudojami. Postmodernistų požiūris ị istoriją remiasi ne visišku jos ignoravimu, o jos interpretavimu, pritaikymu šios dienos poreikiams. Postmodernistinè architektūra pabrěžtinai simboliška, tačiau tuo pačiu metu priimtina visuomenei, kadangi yra orientuota ị tai, kad būtų estetiškai patraukli. Postmodernizmas yra priklausomas nuo modernizmo ir prieš tai buvusių stilių, jis teigia formalią raišką bet forma

\footnotetext{
${ }^{11}$ angl. Antis

12 angl. Dekoruota pašiūrè
} 
postmodernistinejje architektūroje gali būti ir interpretacija, ženklas ar simbolis, taigi tuo pačiu vizuali ir asociatyvi. Be viso to, postmodernizmas gali interpretuoti ir modernistines formas, tokiu atveju jis tampa modernus ir postmodernus tuo pačiu metu.

2 lentelè. Pagrindiniai postmodernistinès architektūros meninės raiškos bruožai pagal R. Venturi

Table 2. Basic features of artistic expression of Post-Modern architecture, according to R. Venturi

$\begin{array}{ccc}\text { MODERNIZMAS } & & \text { POSTMODERNIZMAS } \\ \text { Aiškūs elementai } & \leftrightarrow & \text { Mišrūs elementai } \\ \text { Vienareikšmiškumas } & \leftrightarrow & \text { Kompromisai } \\ \text { Tiesioginis } & \leftrightarrow & \text { Iškreiptas } \\ \text { Aiškiai išreikštas } & \leftrightarrow & \text { Dviprasmiškas } \\ \text { Suprojektuotas } & \leftrightarrow & \text { Savaime susiklostęs } \\ \text { Išsiskiriantis } & \leftrightarrow & \text { Kontekstualus } \\ \text { Paprastas } & \leftrightarrow & \text { Sudètingas } \\ \text { Ramus } & \leftrightarrow & \text { Gyvybingas } \\ \text { Monochromiškas } & \leftrightarrow & \text { Polichromiškas }\end{array}$

Kompleksišką postmodernistinès architektūros raiškos dualumą nagrinèja D. Scott Brown (2008) straipsnyje „Learning from Pop“ (1971 m.), kur teigia, jog modernizmo architektūros atstovai turi pripažinti, jog architektūrinę formą apibrèžia ne tik technologijos ar medžiagos, tačiau ir idejos, jog forma negali kilti tiesiogiai tik iš funkcijos, forma yra galutinis ir kompleksiškas idejų ir materijos rezultatas. Panašiai architektūrinę formą apibūdina ir M. Graves (1982), teigdamas, jog pastato formą sukuria du demenys. Pirmasis yra vidinis, struktūrinis, kuris yra nulemtas pastato paskirties, konstruktyvinių ir techninių sprendimų. Antras yra poetiškas, nulemiantis pastato išvaizdą, jame yra užkoduota simbolika, tradicijos, visuomeniniai procesai. Poetiška forma architektūroje yra būtina tam, kad pastatas galètų tapti architektūros objektu, reflektuojančiu visuomenès tradicijas ir socialinius procesus. Ch. Jencks tai ivardina taip: „postmodernizmas visuomet dvilypis: modernistiné statybos 
technologija papildyta kažkuo kitu (dažniausiai vietinėmis tradicijomis) tam, kad architektūra komunikuotų su visuomene" (Jencks 1986).

Remiantis išnagrinėtais šaltiniais pastebima kompleksiška postmodernistinès architektūros meninè raiška, kuri remiasi turiniu (dažniausiai įvairiomis interpretacijomis) ir forma (dažniausiai pasižyminčia dekoratyviomis savybėmis) (3 lentelè).

3 lentelè. Kompleksiškos postmodernistinès architektūros meninės raiškos bruožai

Table 3. Features of artistic expression of complex postmodern architecture

\begin{tabular}{|l|l|}
\hline TURINYS & FORMA \\
\hline Istorizmas & Stilizacija \\
\hline Kontekstualumas & Eklektika \\
\hline Metafora/asociacija & Ornamentika \\
\hline Semiotika & Polichromija \\
\hline Simbolika & Mišri funkcija \\
\hline Reprezentatyvumas & Daugiasluoksniška erdvė \\
\hline Interpretacija & \\
\hline Tradiciškumas & \\
\hline Tautiškumas & \\
\hline
\end{tabular}

Postmodernistinès architektūros raiška Lietuvoje ir užsienyje. Kaip jau minèta, užsienio architektūroje postmodernistinès tendencijos pradejjo ryškèti aštuntajame dešimtmetyje. Lietuvos architektūroje jos pastebetos 8-ojo dešimtmečio pabaigoje, vèliau plètojosi 9-ajame ir 10-ajame dešimtmečiuose. Pasak A. Mačiulio, postmodernistinè architektūra pasižymi trimis pagrindiniais bruožais: „orientacija i praeities architektūros formalias sistemas, istorinių asociacijų užuominas, vadinamaji aliuzionizmą - istorinių asociacijų panaudojimą architektūroje, daugiau jų retrospekciją, išreikštą šiuolaikinèje architektūroje „,cituojant“ nuo paradokso iki ironiško sarkazmo istorines formas, jo eklektizmą <...>; antrą - architektūros sąsajas su vietos kultūros tradicijomis, pastato - su supančia gamta, vadinamaji kontekstualizmą, kur kūrybinio įkvėpimo reikètų ieškoti savo kultūroje ir tradicijose <...>; trečia - architektūrinès formos semiotiką, simbolinę jos reikšmę, kur architektūrinè forma - ženklas, <...> simbolio reikšmè architektūroje“ (Mačiulis 1996). 


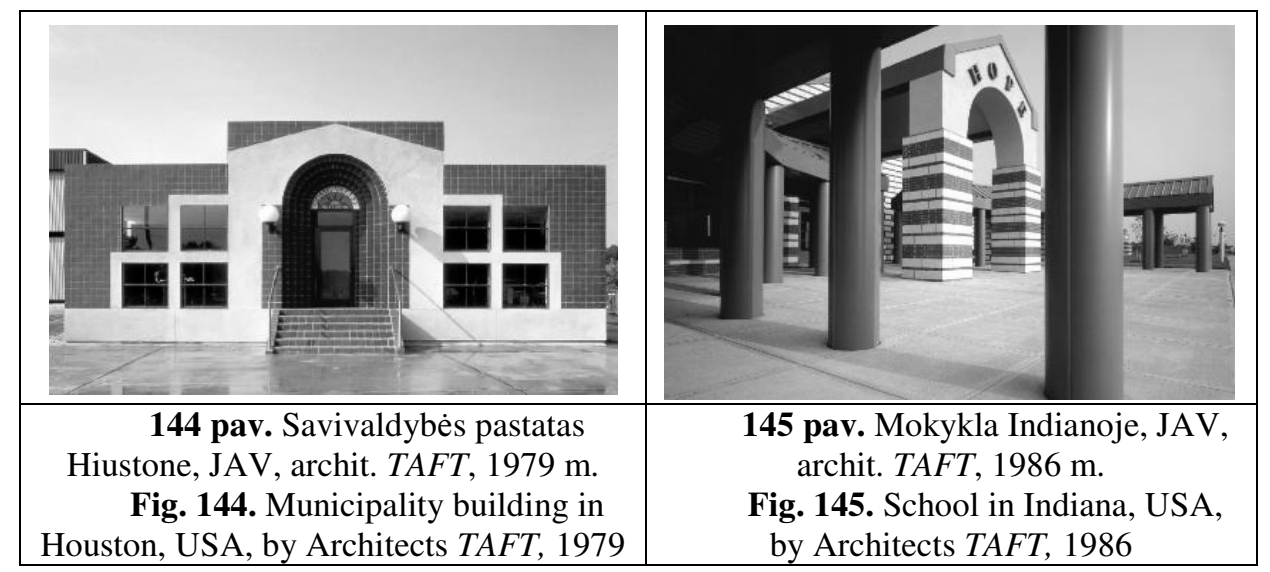

Lietuvos postmodernistinejje architektūroje, ypatingai paplito Venturiškasis „dekoruotos pašiūrès“ konceptas, kaip pagrindines raiškos priemones naudojant stilizuotus istorinius architektūrinius elementus. Tai galima paaiškinti paprastesniu dekoratyvios architektūrinès formos kūrimo procesu, kuris nereikalauja suvokti giluminių postmoderniojo stiliaus priežasčių, nekelia sudètingu formos kūrimo problemų, o tiesiog leidžia kurti pageidaujamą ịspūdị. Dekoratyvūs, stilizuoti architektūriniai elementai pritaikomi naudojant vèlyvąjam modernizmui būdingą tūrinę - erdvinę sąrangą. Toks principas aptinkamas ir pačio R. Venturi, M. Graves, Ch. Moore, Ph. Johnson, „TAFT architektų“, R. Krier ir kt. darbuose.

„Dekoruotos pašiūrès“ koncepto pavyzdžiu galima laikyti savivaldybès pastatą Hiustono mieste, JAV (archit. „TAFT“ 1979 m.) (144 pav.), kur gatvès fasadas suprojektuotas tarsi atskira siena, vizualiai atitraukta nuo pagrindinio pastato tūrio. Pagrindinis arkos formos iẹjimas išdèstytas per viduri, akcentuojant simetriją, kuri pabrežiama paaukštinant parapetą. Fasade naudojama polichromija išryškina fiktyvų frontoną, kuris suteikia plokštumai dualumo. Tai klasicistiné Art-deko interpretacija. Panašūs sprendimai igyvendinti pradinès mokyklos projekte Indianoje, JAV (1986 m.) (145 pav.), kur artikuliuotas arkos motyvas naudojamas kaip iejjimo stogelio konstrukcija, ir mokyklos projekte Hiustone, JAV (1979 m.), kur arkos motyvas pabrèžiamas medžiagiškumo pagalba. Tai tarsi netikras fasadas, siekiant sukurti ištaigingesnio ir ịspūdingesnio pastato ịspūdị.

Antikinio orderio interpretaciją galima ižvelgti administracinio pastato Niujorke, JAV (archit Ph. Johnson 1984 m.) (146 pav.) architektūrinèje raiškoje, kur apatiniai aukštai imituoja pjedestalą, o viršuje matoma kapitelio stilizacija. Ši triguba fasado morfologija gali būti toliau istoriškai interpretuojama, nes akivaizdu, jog vieningo interpretuojamo stiliaus apibrěžti nèra i̇manoma. Pjedestalo arkados motyvas architektūroje naudojamas nuo renesanso laikų, viduriné, kolonos stiebo dalis primena $\mathrm{XX}$ a. pradžios dangoraižiu art-deco 
stilistiką, kapitelio forma galètų būti Claude-Nicolas Ledoux darbuose matomų frontono elementu stilizacija. Orderio interpretacijos matomos ir M. Graves projektuotuose administraciniuose pastatuose Portlande, JAV (1980-1983 m.) (147 pav.) ir Luisvilyje, JAV (1982-1986 m.) (148 pav.), kur be istorinių formų stilizavimo pastebimos ir italų racionalizmo tendencijos (Jencks 1982).

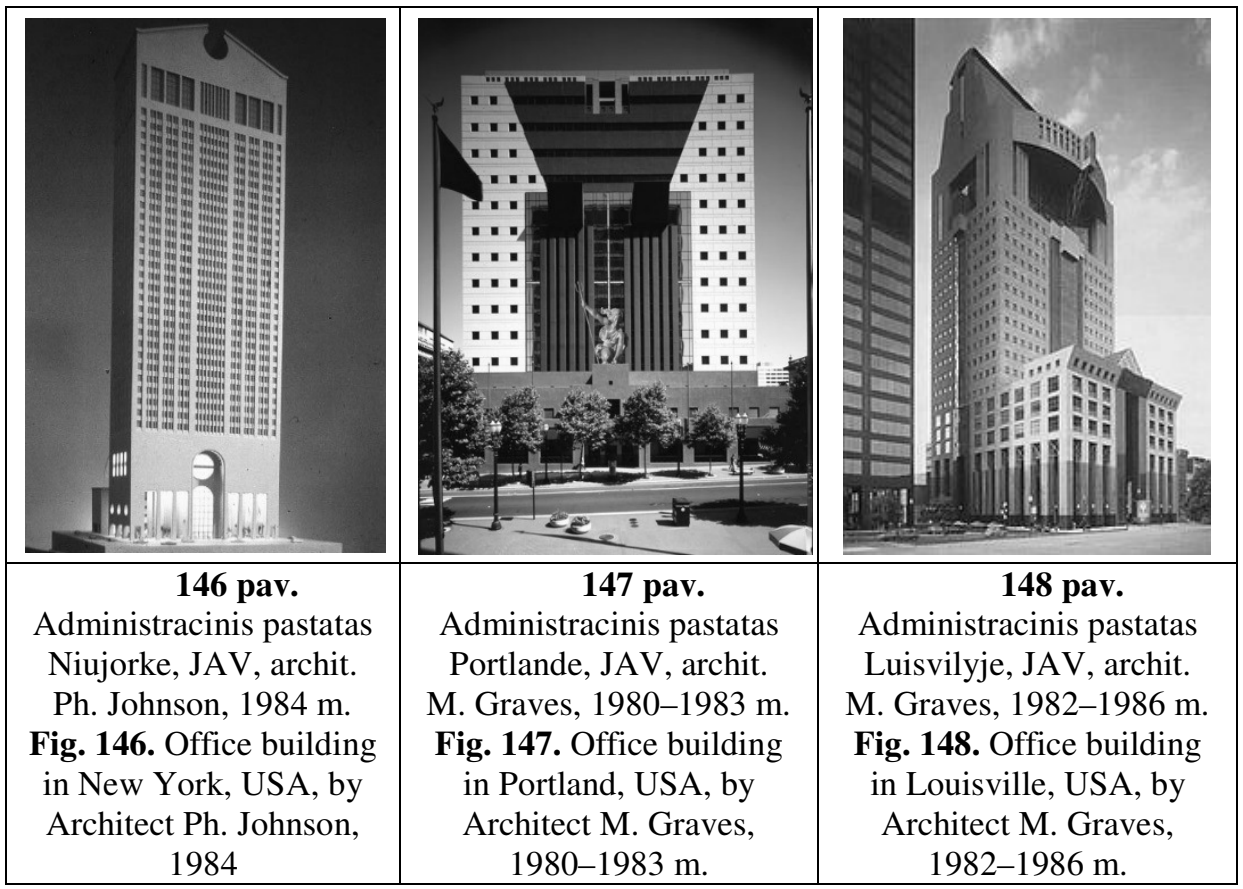

Eklektišku istorinių formų derinimu pasižymi architekto Ch. Moore suprojektuota „Piazza d'Italia“ aikšte Naujajame Orleane, JAV (1975-1980 m.) (149, 150 pav.). Pasak Ch. Jencks, eklektizmu galima vadinti objektą, kurio architektūrinę raišką lemia trys pagrindiniai faktoriai: a) kontekstas; b) atliekamų funkcijų ivvairovè; c) pataikavimas vartotojiškam skoniui. Visa tai aiškiai atsispindi „Piazza d'Italia“. Aikšte įrengta mišriame Naujojo Orleano rajone, toks kontekstas paaiškina nepaprastai išraiškingų formų derinimą tarpusavyje. Prieigose išdèstytos arkados ir pergolès veda lankytoją link aikštès centro, kuris pagal visas istorinių aikščiu tradicijas turètų būti simetriškas, tačiau viduryje išdèstyta kaskada atkartoja Italijos „batą“ žemèlapyje. Aikštès centre - sicilijos salos piešinys. Aukščiausioje aikštès vietoje - Italijos alpès. Panašus eklektikos pavyzdys galètų būti kelionių agentūros biuro interjeras Vienoje, Austrijoje (archit. H. Holein 1978 m.) (151 pav.). Čia eklektika panaudota tiesiogiai biuro paskirčiai apibrèžti. Piramidès dalis, atremta ị sieną simbolizuoja kelionę į Egiptą, bronzinès palmės - dykumų oazes, korintinio orderio fragmentas - Romą, ir t.t. 
Abstraktūs kelionès simboliai šiuo atveju skirti sukurti surrealumo nuotaiką (Jencks 1982).

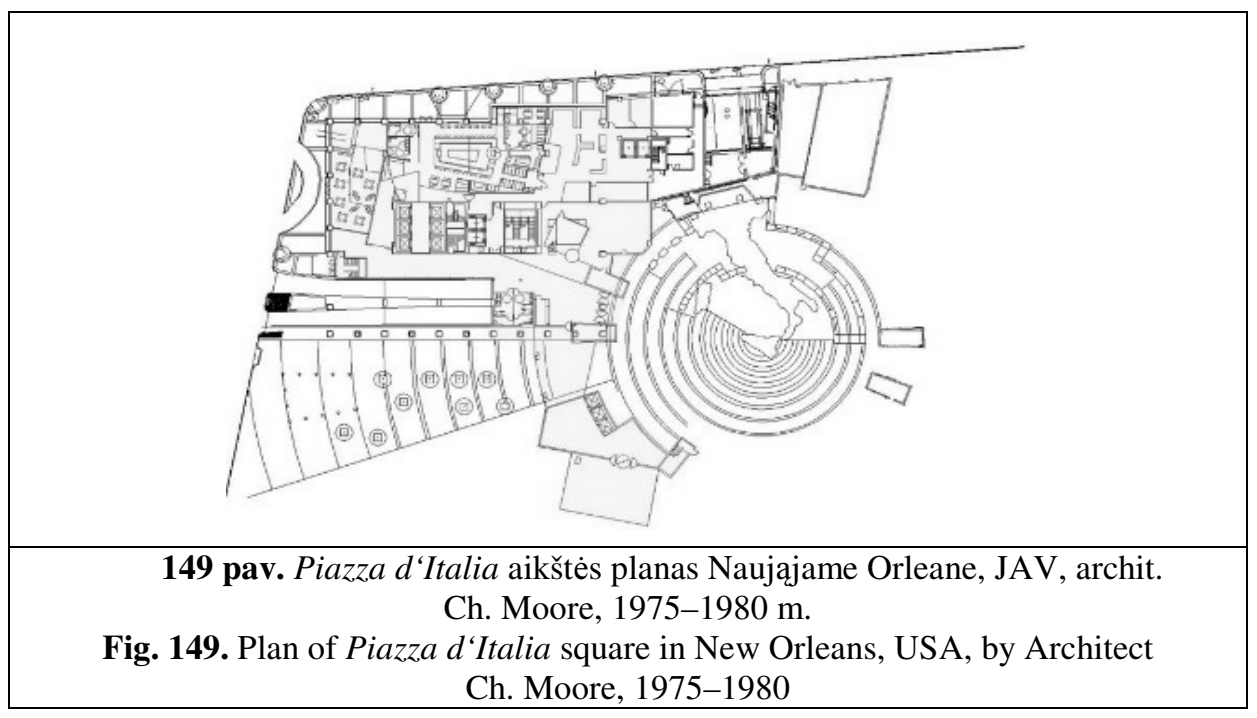

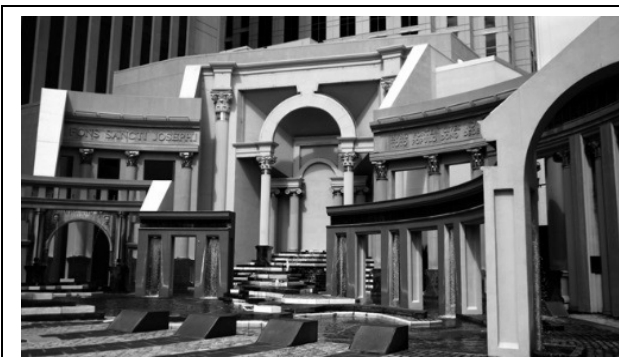

150 pav. Piazza d'Italia aikštè

Naujajame Orleane, JAV, archit.

Ch. Moore, 1975-1980 m.

Fig. 150. Piazza d'Italia square in New

Orleans, USA, by Architect Ch. Moore, 1975-1980

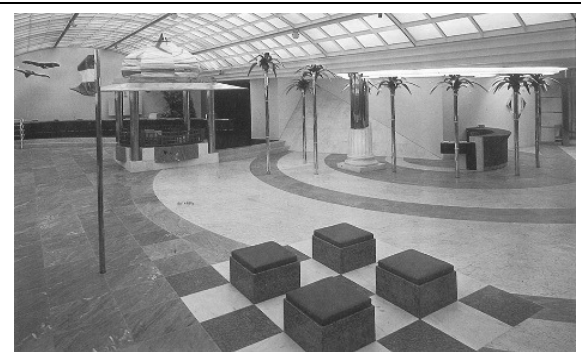

151 pav. Kelionių agentūros biuro interjeras Vienoje, Austrijoje, archit.

H. Holein, $1978 \mathrm{~m}$.

Fig. 151. Office of a travel agency in

Vienna, Austria, by Architect. H. Holein, 1978

Vienas iš pirmujų postmodernizmo raiškos bruožų Lietuvos architektūroje, aptinkamas aštuntojo XX a. dešimtmečio pabaigoje, Romualdui ir Aušrai Šilinskams suprojektavus klubo pastatą Palangoje (1979 m.) (152 pav.). Šiame objekte panaudoti istoriniai arkos motyvai, viena ju akcentuoja iejjimo svarbą, kitos naudojamos dekoratyviniais tikslais, greta naudojamas apvalus, tarsi rozetès motyvas. Istoriniai elementai šiuo atveju naudojami vèlyvojo modernizmo kontekste, kadangi erdvinè tūrinè sąranga vadovaujasi modernistiniais projektavimo principais. Portalo akcentavimas stilizuotu arkos elementu pastebimas ir Klaipedos dramos teatro naujojo korpuso fasade (archit. 
S. Manomaitis 1979-1989 m.) (153 pav.). Arkos elementas atlieka išskirtinai dekoratyvinę funkciją ir be viso to dar yra pabrèžiamas tarsi iškirsta griežtų formų fasado plokštumos anga. Šiame pastate pastebimas Ch. Jencks (Jencks 1982) aprašytas erdvių skaidymo metodas, kuomet erdvès atskiriamos dekoratyvinėmis pertvaromis siekiant išvengti vèlyvajam modernizmui būdingos monotonijos.

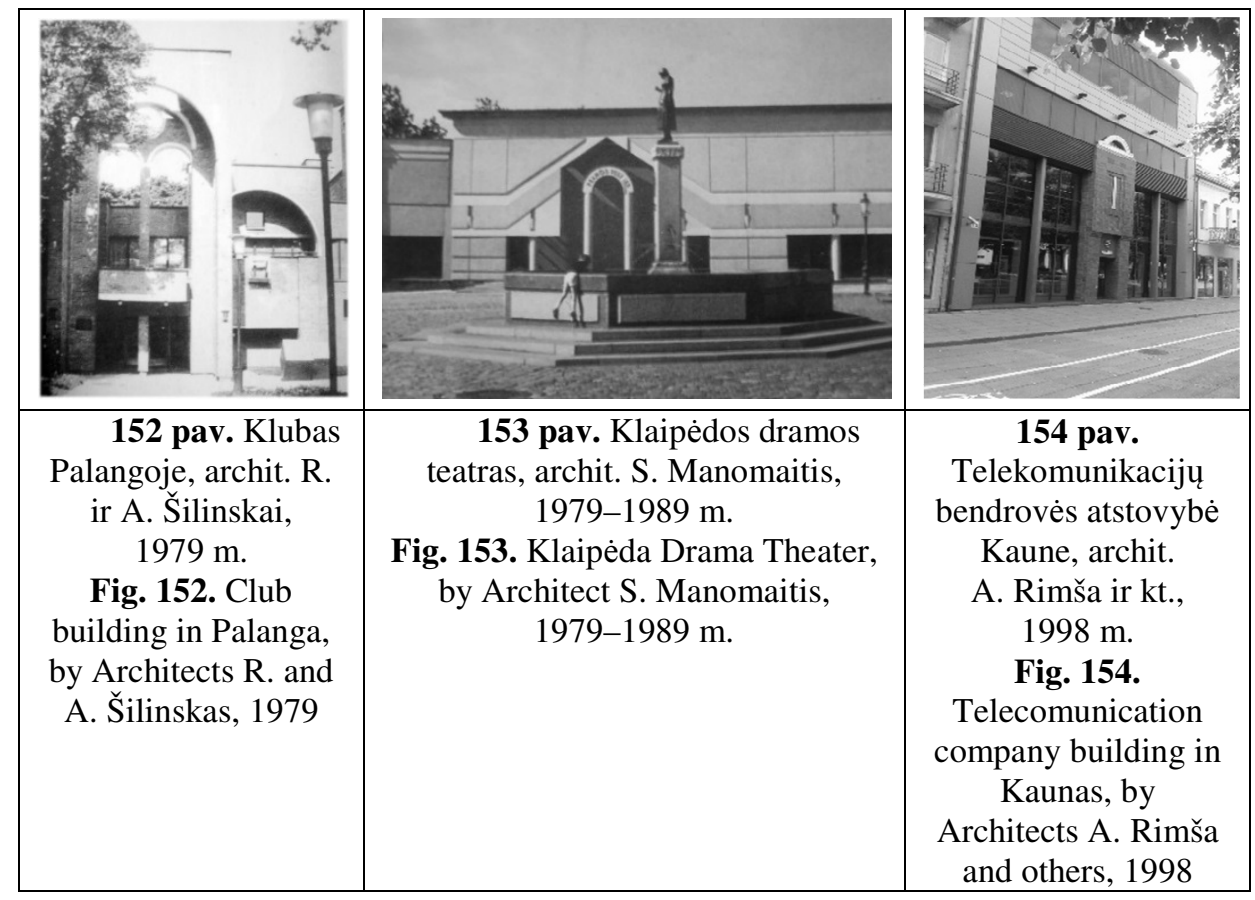

Telekomunikacijų bendrovès atstovybès pastato Kaune (archit. A. Rimša, E. Vilčinskas, D. Gutauskienè 1998 m.) (154 pav.) portikas akcentuojamas jau ne tik forma, tačiau ir medžiagiškumu. Slick-tech estetika pasižyminčio pastato gatvès fasade pirmieji du aukštai įtraukti ị vidų, taip išryškinant „akmeninị““ stilizuotų istorinių formų portalą, pabrèžtą liaunomis, nuo stiklo plokštumų atitrauktomis kolonomis. Taisyklingu formų, racionalaus tūrio ir išplanavimo pastatas praturtinamas postmodernistiniu portiku tiesiai per pagrindinio fasado vidurį. Pramoninès architektūros estetiką atspindinčio fasado tūrị skaido kiek itraukta atvira pirmujų aukštų vertikali plokštuma (klientų prièmimo zona), kurią keičia horizontaliai orientuota dviejų viršutinių aukštų zona (trečiojo aukšto administracinès ir ketvirtojo aukšto inžinerinès patalpos), užsibaigianti pusiau cilindriniu skardos stogu (Tutlytė 1998). Postmodernistinių detalių fragmentiškos apraiškos - būdingas XX a. pab. Lietuvos architektūros bruožas.

Vèlyvojo modernizmo architektūroje galima pastebėti ir kitų stilizuotų istorinių architekūrinių formų. Algimanto Kančo suprojektuotame Maltos ordino 
senelių namų komplekse Kaune (1985 m.), laiptinès tūris užbaigiamas piramidès formos stogeliu, pabrèžiančiu iejjimą i pusiau uždarą vidinį kiemą. Kompleksas pasižymi jautrumu gamtinei aplinkai, aliuzijomis ị viduramžių pilių architektūrą. Panašia architektūrine raiška pasižymi ir M. Šaliamoro ir J. Balkevičiaus suprojektuota kunigų seminarija Vilniuje (1998 m.) (155 pav.). Monumentalus raudonų plytų mūro tūris turi aliuzijų ị vienuolynų architektūrą, tačiau tuoj pat sušvelninamas stilizuotais karnizais, šlaitiniu stogu, iejjimas pabrèžtas stilizuota kolonada. Polifunkciniame pastate Marijampoleje (archit. L. Tumyniené ir kt. 1993 m.) (155 pav.) naudojama jau daugiau istoriniu detaliu, o taip pat ir polichromija. Pagrindinis iejjimas taipogi pabrěžiamas stilizuota kolonada ir trikampio tūrio stogu, simetriškai perkirstu dekoratyvine plokštuma. Fasade nebèra vèlyvajam modernizmui būdingo solidumo, langų formos pabrèžtinai skirtingos, karnizo linija perkertama pusapvaliu lango plokštumos elementu. Arkos elementai pastebimi tiek langu formose, tiek pabréžiant iejjimą i vidinị kiemą.

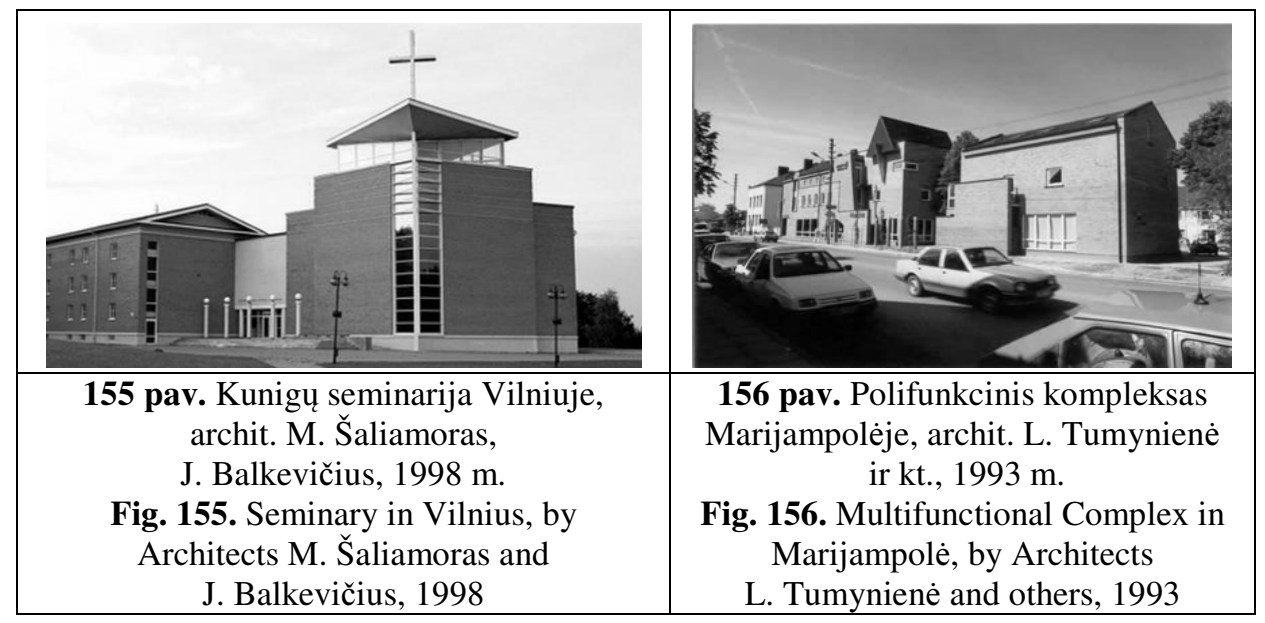

Kolonados ir portiko akcentas aiškiai pastebimas Lazdijų rajono apygardos Teismo rūmuose (archit. A. Mazūras 1994 m.) (157 pav.), tačiau šiame objekte jau pastebimas ir planinès struktūros artejjimas prie postmodernistinès architektūros. İejjimas akcentuojamas jau ne tik stilizuotų dekoratyvių elementų pagalba, bet ir jo atžvilgiu simetriško patalpu išdèstymo. Čia igyvendinta ir vidinio kiemo ideja, kurio meninè raiška gerokai atviresnè, kontrastuojanti šaltam ir monumentaliam išorès ịvaizdžiui. Anksčiau aptartą klasikinio orderio interpretaciją, būdingą užsienio postmoderniajai architektūrai, galima įžvelgti Japonijos ambasados pastate Vilniuje (archit. D. Ruseckas 1997 m.) (158 pav.). 


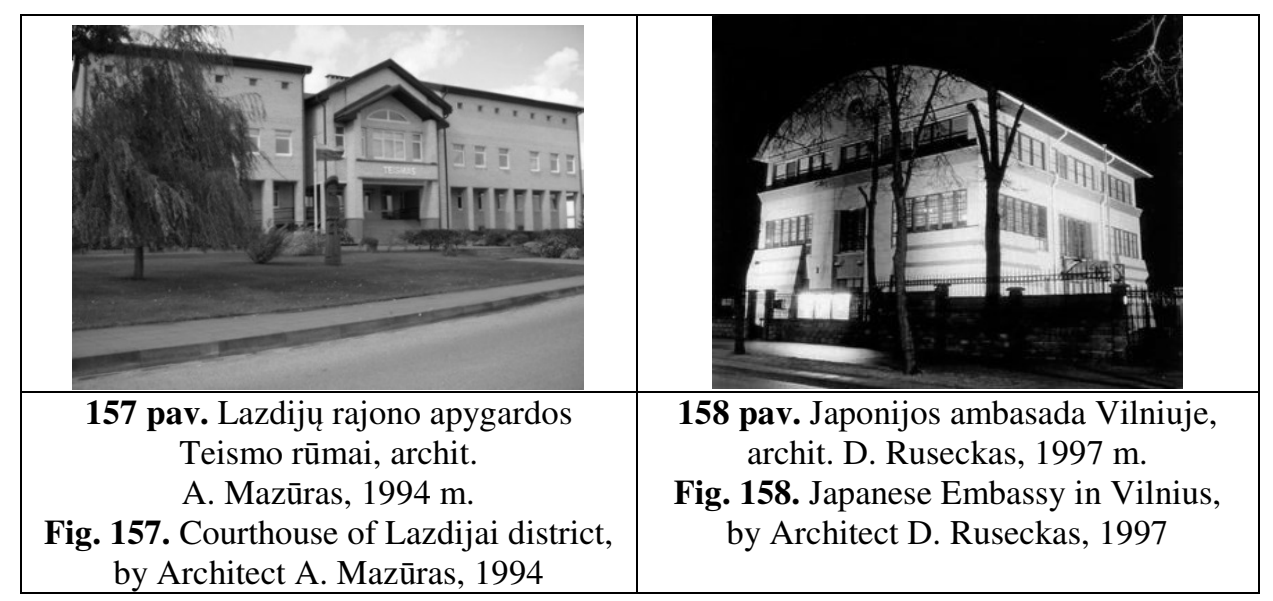

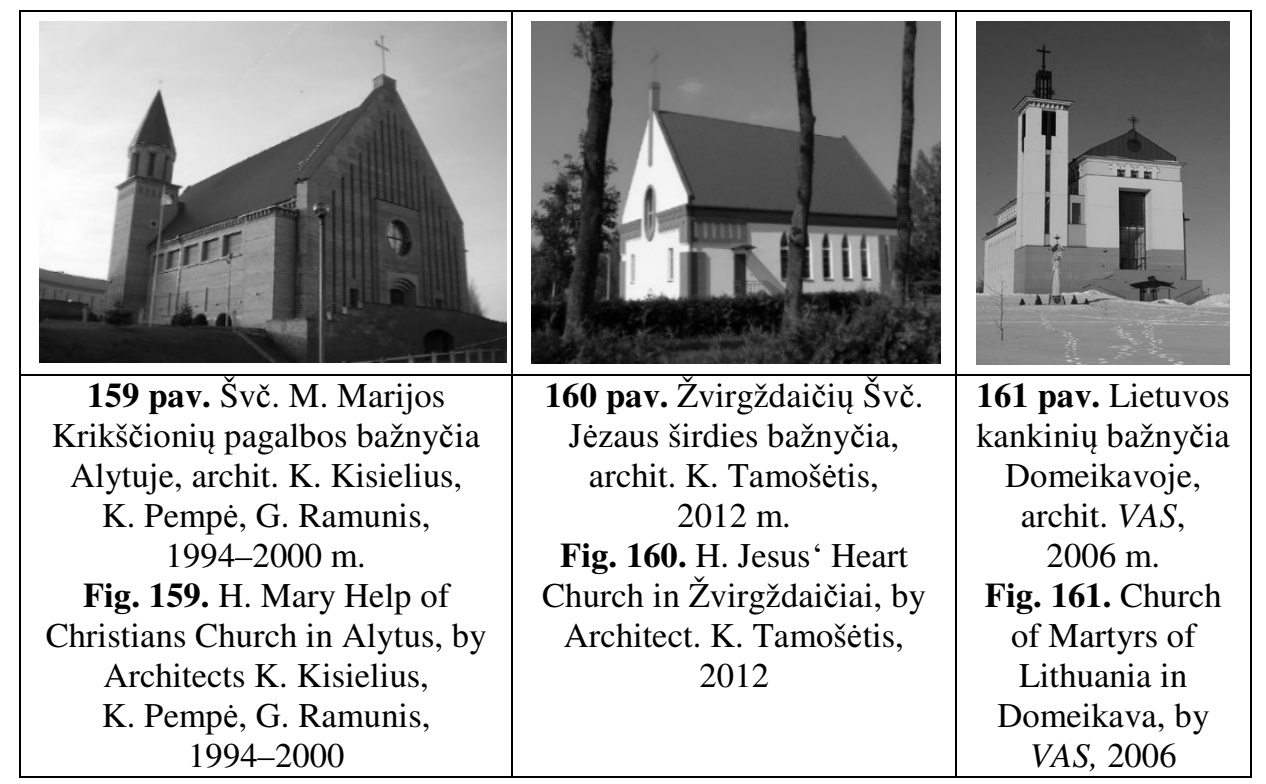

Tam tikrais atvejais, postmoderniojoje Lietuvos architektūroje, istorinių formų adaptacija peržengè stilizacijos rèmus, pradèta naudoti tiesiogiai. Tai ypatingai pastebima bažnyčių architektūroje. Pavyzdžiui, Švč. M. Marijos Krikščionių pagalbos bažnyčioje Alytuje (archit. K. Kisielius, K. Pempé, G. Ramunis 1994-2000 m.) (159 pav.), taip pat K. Tamošéčio suprojektuotose Panevėžio Šv. Kryžiaus išaukštinimo bažnyčioje $(2007$ m.) ir Žvirgždaičiu Švč. Jèzaus širdies bažnyčioje (2012 m.) (160 pav.), taip pat Lietuvos kankiniu bažnyčioje Domeikavoje (archit. „Vilniaus architektūros studija“ 2006 m.) (161 pav.) ir kt. Kituose objektuose tiesioginiai istoriniai elementai naudojami tradiciškumui ir prabangumui ịtvirtinti, pavyzdžiui banko pastate Kretingoje 
(archit. E. Giedrimas 1995 m.), taip pat gyvenamajame name - rezidencijoje Pilies g. Vilniuje (archit. V. Nasvytis ir kt. 1999 m.), ir kt.

Tiesioginiam istorinių formų aplikavimui postmoderniojoje Lietuvos architektūroje galima priskirti ir tautinès architektūros interpretacijas, dažnai turinčiomis kičo elementų. Tai architektūra turinti aliuzijų i istorines vietines tradicijas, dažniausiai nedisponuojanti tarptautinèmis istorinemis formomis, dažniau jas galima pavadinti liaudiškomis (Mačiulis 2008) arba etninèmis (Gabrènas 2012).

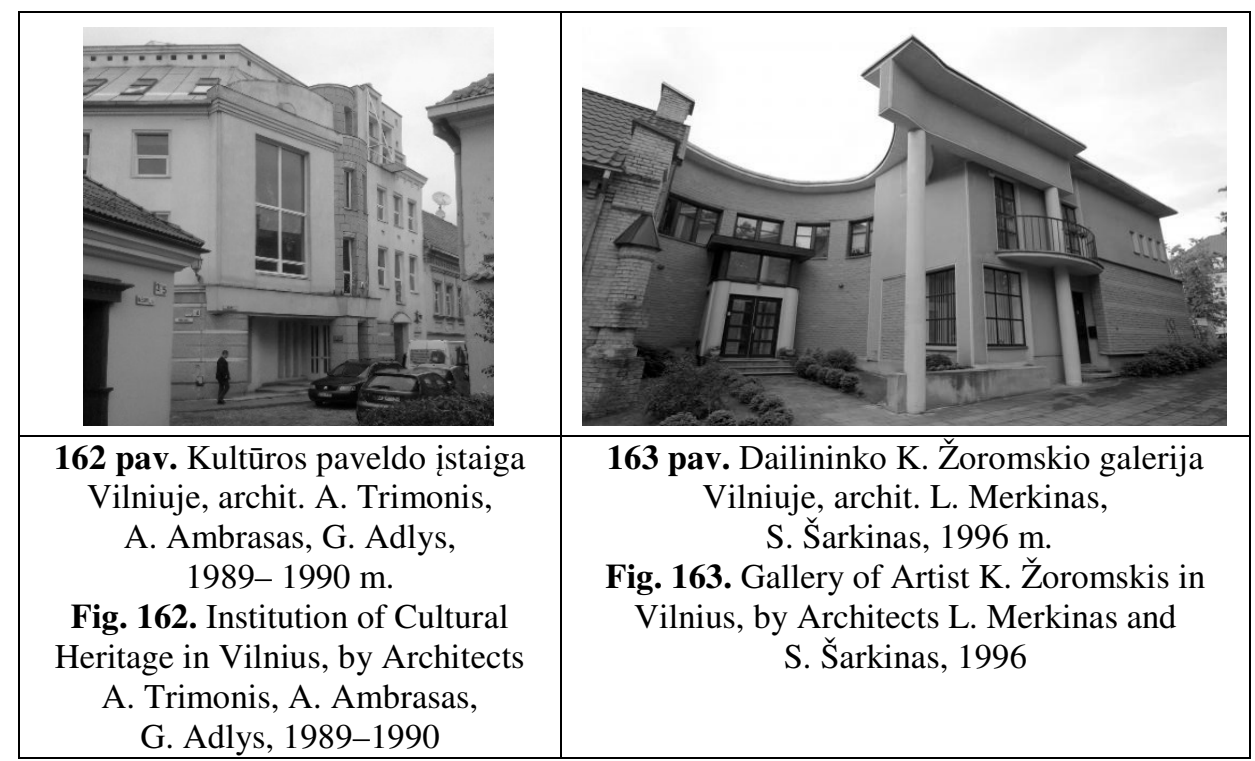

Eklektiška istorinių formų interpretacija pasižymi buvęs prekybos centras „Vaivorykštė“ Marijampoleje (archit. K. Jurènas 1992 m.). Komplekso architektūrinèje raiškoje galima aptikti kūgio formos stogelį, užbaigiantị cilindro formos prekybini korpusą, medžiagiškai išryškintą metalinę koloną užbaigtą stilizuotu kapiteliu, iejjimo akcentą, pabrěžtą dviejomis kolonomis, netgi high-tech elementų stogo konstrukcijoje. Kultūros paveldo instituto pastate Vilniuje (archit. A. Trimonis, A. Ambrasas, G. Adlys 1989-1990 m.) (162 pav.), Mèsinių g. fasade galima įžvelgti išdidintą lango fragmentą, ginybinei architektūrai būdingo bokšto aliuziją ir tradicinį senamiesčiui būdingą gatvès fasadą, kuris vietoje stogo netikètai užbaigiamas antstatu ir nedideliu balkonu. Vidinio kiemo fasade netikètu kampu pasvirusi plokštuma imituoja arkadą, atremtą i puskolonę su kapiteliu. Dailininko K. Žoromskio dirbtuvès ir galerijos pastate Vilniuje (archit. L. Merkinas, S. Šarkinas 1996 m.) (163 pav.), stilizuotas orderio fragmentas derinamas su pusapvaliu karnizu, taip paliekant neužbaigtos formos îspūdị. G. Ramunio ir K. Pempés projektuotame polifunkciniame pastate Vilniuje (19981999 m.), aktyvus karnizo motyvas pabrèžia dvi netaisyklingo pastato kryptis. 
Monumentali plytų mūro forma tarsi pridengta postmodernistinèmis dekoratyvinèmis formomis, erkeriais, spalvotomis detalemis (164 pav.).

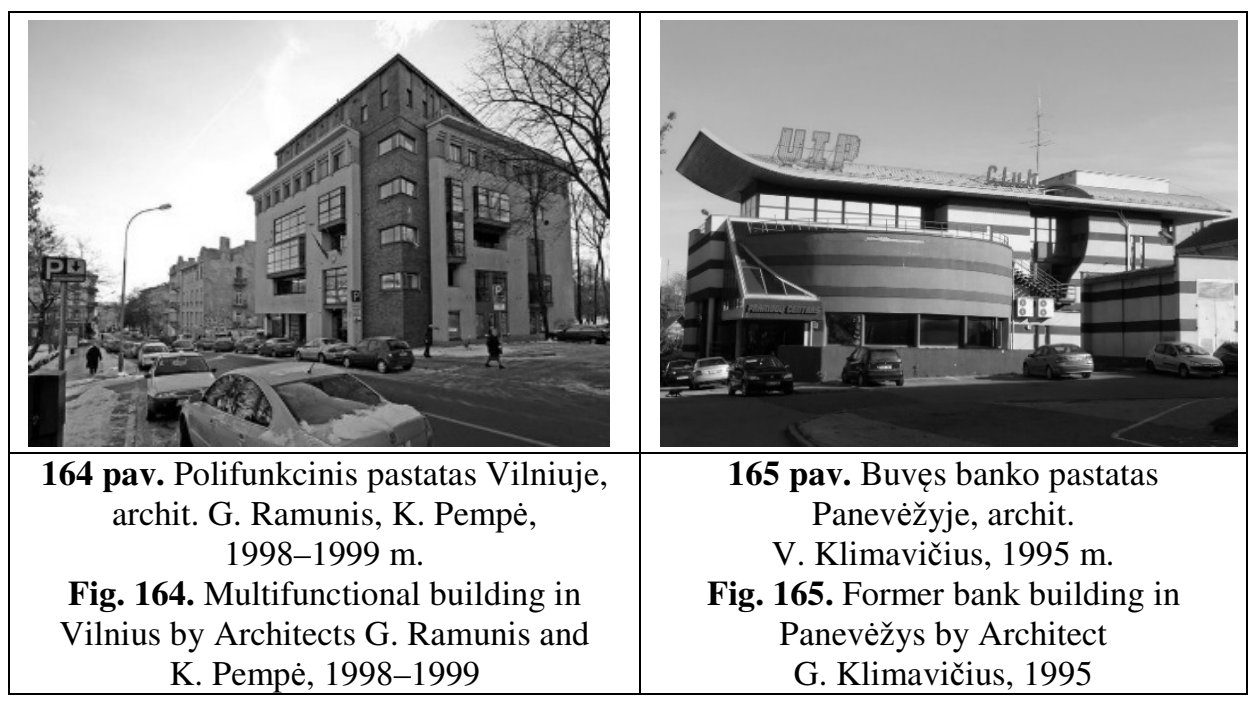

Eklektišku įvairių formų ir pusformių žaismu pasižymi banko (dab. įvairios paskirties) pastatas Panevėžyje (archit. V. Klimavičius 1995 m.) (165 pav.). Nepaisant numatytos konservatyvios pastato funkcijos, nevengiama paieškoti plastiškų formų, pabandyti jas derinti su taisyklingomis geometrinèmis. Ganètinai aiški ir nuosaiki pastato planine struktūra išoreje tampa fragmentišku ir sunkiai suvokiamu tūriu, aplipdytu sudètingais architektūriniais elementais. Panašūs sprendimai pastebimi Klaipédos miesto apylinkès Teismo priestate (archit. R. Valiukonis 1999 m.),taip pat ir prekybos centro „Vici“ pastate Panevéžyje (archit. L. Paulauskiené 1999 m.), kur eklektiška architektūrinè ekspresija balansuoja ant kičo ribos, bei buvusiame prekybos centre „Promenadas“, Vilniuje (archit. S. Gecas ir R. Pilkauskas 1995 m.), kur kiekvienas atskiras korpusas išreikštas skirtinga architektūrine raiška.

Istorinių elementų stilizacija postmoderniojoje architektūroje plačiai naudojama siekiant kontekstualumo, projektuojant naujus pastatus senamiesčio aplinkoje ar bandant prisitaikyti prie charakteringų vietos objektų. Pastarasis konceptas aiškiai izžvelgiamas naujajame M. Mažvydo bibliotekos priestate Vilniuje (archit. G. Baravykas, L. Majerienè 1986 m.), kuriame naudojamas stilizuotos karnizo linijos elementas, taip pat aliuzija i senojo pastato portalo kolonadas, kurias naujajame pastate atstoja puskolonès. Alytaus savivaldybès administraciniame pastate (archit. S. Juškys 1989 m.) galima įžvelgti istorinių pastatų kompozicijos principų, taip pat XX a. antros pusès italų racionalizmo tendencijų. Išraiškinga aliuzija $\mathfrak{i}$ istorines formas pasižymi vienas pirmujų postmodernistinių objektų Lietuvos architektūroje - daugiabutis gyvenamasis 
namas Vilniuje (archit. A. Trimonis, G. Čaikauskas, A. Ambrasas 1986-1987 m.) (166 pav.). Kontekstualų pastato charakteri išreiškia nuosaikus mastelis, sienamiesčiui būdingi tūriai, langų angos, nišos, karnizai, ịvairios stilizuotos istorinès detalès. Pirmajame aukšte suprojektuotos visuomeninès ir komercinès patalpos i kurias patenkama kiemo vartus primenančiu iejjimu. Kiek labiau stilizuota, tačiau neabejotinai istorinių formų itakota menine kalba pasižymi Vytauto Didžiojo gimnazijos naujasis pastatas Vilniuje (archit. J. Makariūnas 2002 m.) (167 pav.), kurio kontekstualus charakteris nedisonuoja senamiesčio aplinkoje.

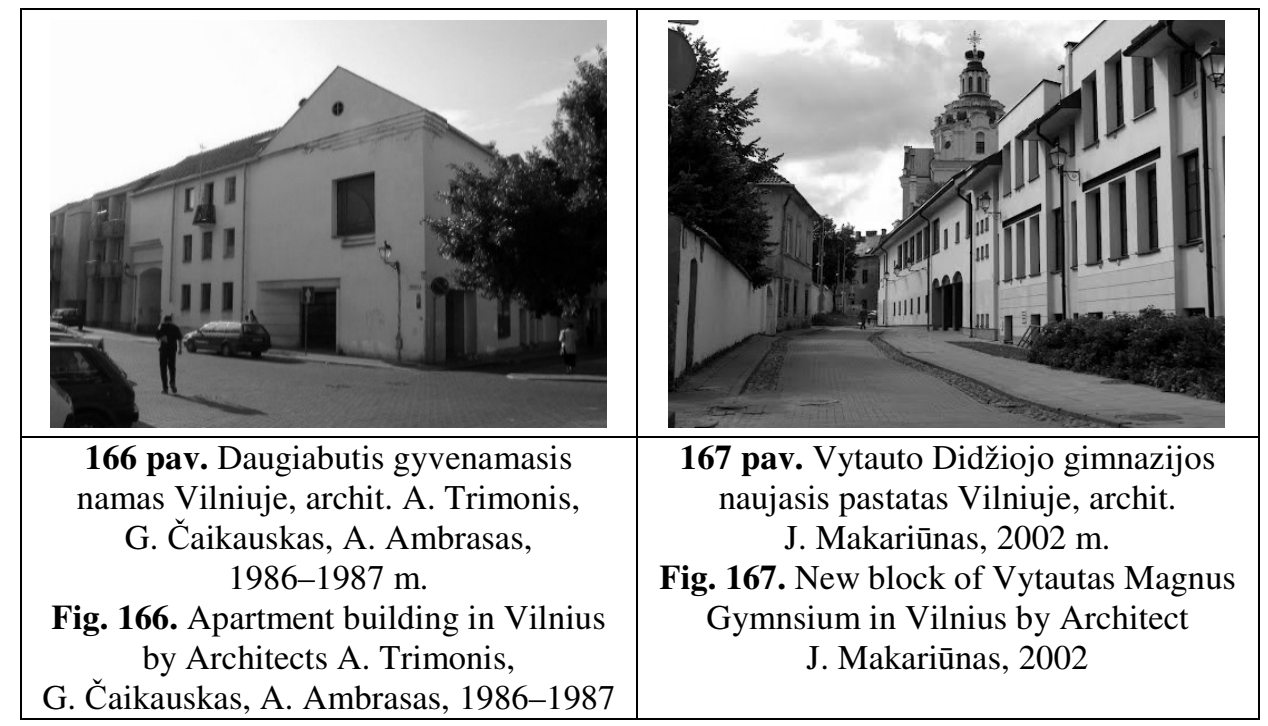

Panašiais tikslais vadovautasi projektuojant Seimo viešbuti Vilniuje (archit. A. E. Paslaitis, 1989 m.) (168 pav.). Pastato tūris ir masteliškumas prisitaiko prie Gedimino prospekto charakterio, naudojama įmantri architektūrinė kalba dekoratyvinès formos, stikliniai erkeriai, polichromija. Trijų daugiabučių namų projekte, Teatro g. Vilniuje (archit. A. Blotnys $1996 \mathrm{~m}$.) ir verslo centre Vilniuje (archit. A. Songaila, 2000 m.) (169 pav.), atkartojant Senamiesčio pastatų charakterị nevengiama manieringumo, kartais nebūdingo istoriniam užstatymui, stikliniai erkeriai čia užbaigiami balkonais, stilizuoti karnizai kai kur perkertami pusapvalèmis formomis. Pagarba esamam užstatymui pasižymi ir konferencijų centro Vilniuje pastatas (archit. K. Pempè, K. Kisielius, G. Ramunis ir kt., 1999 m.) (170 pav.), kur cilindro formos bokštą primenantis tūris atspindi pasaulines postmodernistines tendencijas. 


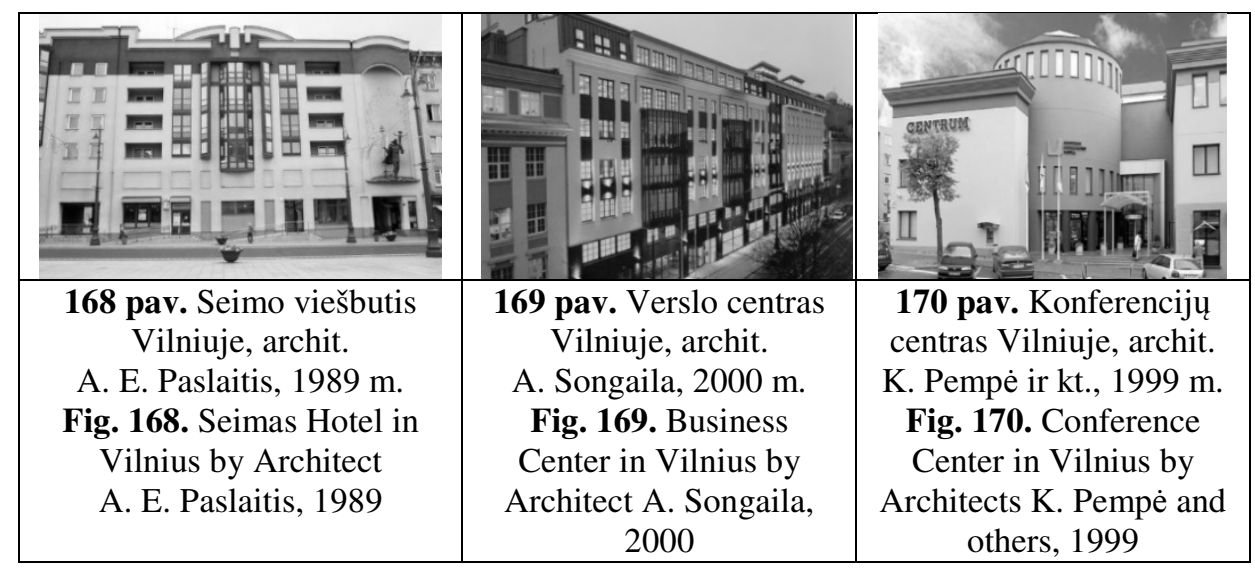

\begin{tabular}{|c|c|}
\hline 171 pav. Krašto apsaugos ministerijos centrinis \\
gynybinis štabas Vilniuje, archit. \\
E. N. Bučiūte, 1997 m. \\
$\begin{array}{c}\text { Fig. 171. Central Defensive Headquarters of } \\
\text { the Ministry of Defense in Vilnius, by } \\
\text { Architect E. N. Bučiūte, 1997 }\end{array}$ \\
$\begin{array}{c}\text { Fig. 172. SEB bank in Vilnius, by } \\
\text { Architect K. Pempé, } \\
\text { G. Ramunis, 1996 }\end{array}$ \\
archit. K. Pempé,
\end{tabular}

Vienas ryškiausių kontekstualaus stilizuotų istorinių formų panaudojimo atvejų šiuolaikinèje Lietuvos architektūroje, būtų dabartinio „SEB“ banko pastatas Vilniuje (archit. K. Pempè, G. Ramunis. 1996 m.). Pagarba kontekstui čia pastebima pastato mastelyje ir fasado horizontalèse, atkartojančiose greta esanti užstatymą (paaukštintas cokolis, išlaikyta karnizo linija). Dauguma architektūrinių elementų - tapukario Lietuvos moderniosios architektūros interpretacija, pabrežta simetrijos aši akcentuojančiu stiklo erkeriu, kurị užbaigia dekoratyvus frontonas (172 pav.). Pagarba istorinèms formoms pasižymi E. N. Bučiūtès suprojektuotas Krašto apsaugos ministerijos centrinio gynybinio štabo kompleksas Vilniuje $(1997$ m.) (171 pav.). Kontekstualumas čia suvokiamas kaip buvusio užstatymo interpretacija. Keturi Šv. Ignoto gatvejje išdėstyti frontonai simbolizuoja anksčiau buvusį užstatymą, vienas kurių tiesiog pakabintas virš Totorių gatvès. Totorių gatvès fasade galima įžvelgti senamiesčiui 
būdingą masteliškumą, langų dalijimo stilizaciją, tačiau piramidès formos stiklinis stogelis, itraukta stogo linija rodo pasaulinès postmodernizmo architektūros įtaką.

Kontekstualumas, kaip postmodernistinès architektūrinès raiškos siekis taip pat naudojamas stilizuojant ir interpretuojant tradicinès architektūros formas ir elementus. Vienas pirmujų tokių bandymų - Mokslų akademijos fizikos instituto poilsio namai Preiloje (archit. G. Telksnys 1985 m.), kur interpretuojamos tautinei architektūrai būdingos formos, tačiau kai kurie elementai paverčiami ornamentais, pavyzdžiui turèklai, kolonų kapiteliai. Trikampis stogo tūris paryškintas baltu rèmeliu, kurio viduryje vietinei architektūrai būdingas langas, tačiau čia jis stilizuotas, paverstas ornamentu. Nidos bažnyčios projekte (archit. R. Krištapavičius, A. Zaviša 2003 m.) (173 pav.) konteksto problema išspręsta naudojant vietinei architektūrai būdingas medžiagas, stilizuojant vietinès architektūros formą, paverčiant ją centrine bažnyčios nava. Atviros medžio konstrukcijos dažomos balta spalva, kontrastuojančia tamsiam pagrindiniam tūriui, tuo paryškindamos konstruktyvinį raštą, kuris būdingas visai pajūrio architektūrai.

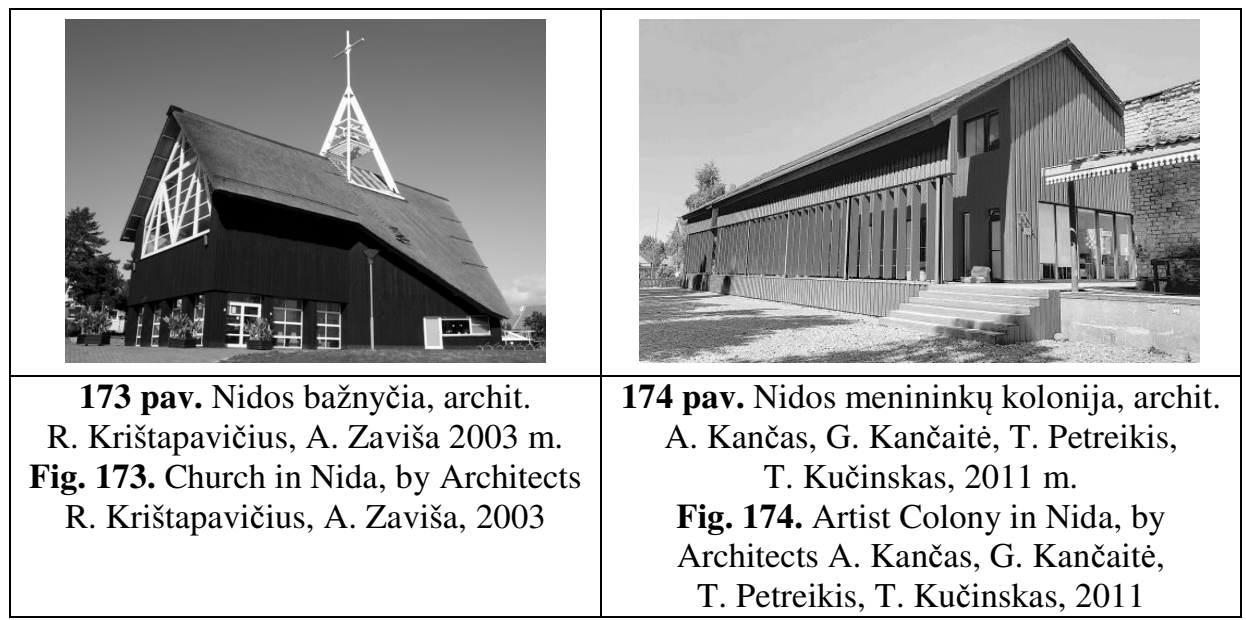

Nidos menininkų kolonijos rekonstrukcijai pasirinkta vietinių architektūrinių formų interpretacija (archit. A. Kančas, G. Kančaite, T. Petreikis, T. Kučinskas 2011 m.) (177 pav.). Anksčiau buvęs dviejų aukštu pastatas praplèstas papildomai įrengiant dar vieną, masardinį aukštą. Komplikuota achitektūrinė forma primena tris, viena šalia kito sujungtus tradicinius žvejo namukus. Masyvų tūrị apdailintą tamsiomis medinèmis dailylentemis pagyvina ryškiai raudonos spalvos intarpai, vidinè, ant stogo įrengta terasa, taip pat pagrindiniame fasade įrengta galerija, kuri pridengiama vertikalių žaliuzių ritmika. Panašus sprendimas, architektūrinès formos prasme, igyvendintas naujajame viešbučio korpuse Klaipėdoje (archit. J. R. Palys, J. Audejaitis, G. Kezys 2007 m.) (175 pav.). Pasak architektų, tai yra 
Klaipèdos uosto sandèlių interpretacija, iš to kilo tiek smailaus dvišlaičio stogo forma, tiek įvažos motyvas viename iš pastato fasadų (Štelbienė 2013). Pastatas, nors savo forma ir motyvais kontekstualus, dèl nebūdingos aplinkiniam užstatymui apdailos (tiek sienų, tiek stogo dangai panaudotos oksiduoto vario plokštelès) išsiskiria iš aplinkos, kuria autonomiško objekto įspūdị.

Kontekstualia vietinio architektūrinio charakterio interpretacija pasižymi „Ryžių malūno“ rekonstrukcija Klaipėdoje (archit. A. Stripinis, S. Stripinienè, E. Kaltanaitè, K. Jurkute 2007-2008 m.) (176 pav.). Po II-ojo pasaulinio karo iš dalies sunaikinto pastato liko tik pirmasis aukštas. Remiantis išlikusia istorine medžiaga atkurtas likęs pastato tūris, stogo forma, buvęs fachverko raštas. Tiesa, pastarasis šiuolaikiniame pastate atlieka tik dekoratyvinę funkciją. Šiuo atveju stilizuojamos ne detalès, o pastato konstruktyvinè sąranga.

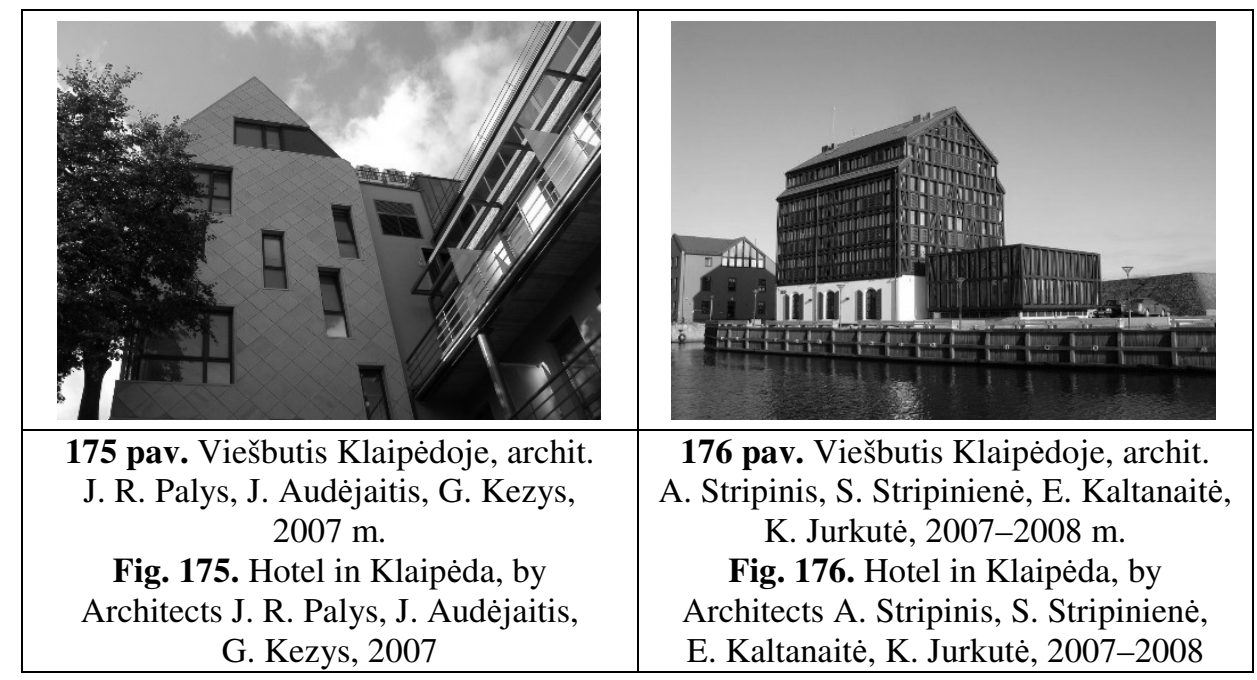

Postmodernistinès erdvès interpretacijos. Kritika modernaus miesto urbanistinėms erdvėms jau aptarta anksčiau, šiame skyriuje (Rowe 2008a). Ten ivardinama, jog pagrindinis modernistinio miestų planavimo trūkumas, tai jo nesugebejimas parodyti kultūrinio perimamumo, teigiama, jog modernistinis miestas neturi gyvybingumo, ryšio su praeitimi. Postmodernistineje architektūroje deklaruojamas pliuralus erdvès suvokimas, kurioje kompleksiškai adaptuojamos ivairios formos ir idejos. Tokia filosofija pastebima R. Walker, O. M. Ungers, R. Bofill, R. Krier, A. Rossi, J. Stirling darbuose.

R. Walker suprojektuotame gyvenamajame name Velingtone, Naujojoje Zelandijoje (1970 m.) bandymas sukurti kompleksišką raišką minimaliame mastelyje išreiškiamas istorinių formų interpretacijomis (177 pav.). Smailūs bokšteliai žymi skirtingas erdves, kambarius, taip sukurdami didesnio urbanistinio komplekso îspūdị. Chaotišką architektūrinę ekspresiją paryškina apvalūs langų motyvai, terasos, tūriniai stoglangiai. Panašią idèją, tik jau 
didesniame mastelyje igyvendino R. Bofill gyvenamujų namų kvartale Reus mieste, Ispanijoje (1964-1970 m.). Šiame pastatu komplekse naudojamos vèlyvąjam modernizmui būdingos architektūrinès formos, tačiau jos išdèstytos istorinių miestu planavimo principu, siekiant sukurti senovinio Antikinio miesto ispūdį - kupiną aikščių, gatvių ir arkadų (178 pav.). Pusiau uždara tūrine kompozicija, sukuriančia vidini kiemą pasižymi J. Stirling suprojektuota galerija Štutgarte, Vokietijoje (1977-1982 m.) (179, 180 pav.). Šis urbanistinio kotekstualizmo pavyzdys savo architektūrinejje raiškoje adaptuoja visus pagrindinius postmodernizmo elementus. Pagarba kontekstui matoma komplekso išdėstyme aplinkinių pastatų atžvilgiu, $\mathrm{U}$ formos simetriškas vidinis kiemas apgaubia centre esančią apvalią lauko galeriją, kuri yra tarsi „kupolas, kuriam trūksta viršutinès dalies“ (Jencks 1982). Daugiasluoksniškose lauko erdvèse gausu rampų, laiptelių, kelių lygių sankirtų. Pastato raišką paįvairina atviros metalinès konstrukcijos nudažytos ịvairiomis spalvomis, stilizuoti istoriniai elementai.

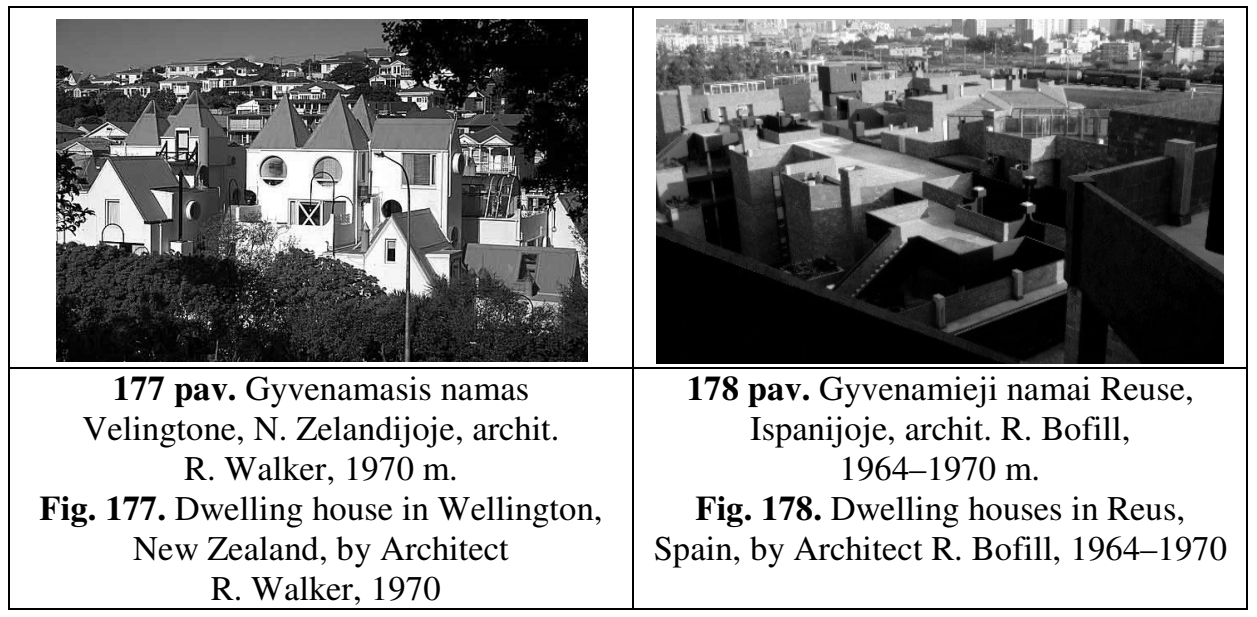

Nors tikrosios „postmodernistinès urbanistinès erdvè““ analogai dažniau matomi užsienio architektūros objektuose, Lietuvoje galima pastebèti lokalių bandymų sukurti senamiesčio gatvelès, kiemo, istorinès viešosios erdvès ar istorinio statinių komplekso įspūdį. Pirmuoju panašaus pobūdžio bandymu vis dar pasižyminčiu vèlyvajam modernizmui būdinga menine raiška, galima laikyti G. Baravyko, G. Ramunio ir K. Pempès suprojektuotą prekybos kompleksą „Šeškinè“, Vilniuje (1978-1985 m.) (181 pav.). Išsidèstęs sostinès miegamajame rajone, prekybinis kompleksas formuojamas aplink pusiau uždarą vidinę erdvę, kurios viduryje akcentas - fontanas su laikrodžiu. Aplink aikštę išdèstyti nuožulnių stogu korpusai, primenantys senamiesčio kiemą, kuriuose projektuojamos nedidelès prekybos ir paslaugu erdvès. Vidinė aikštė apsupta 
galerijomis, kelių lygių praèjimais, kurie vietomis atviri, kitur pridengti dekoratyviniais elementais.

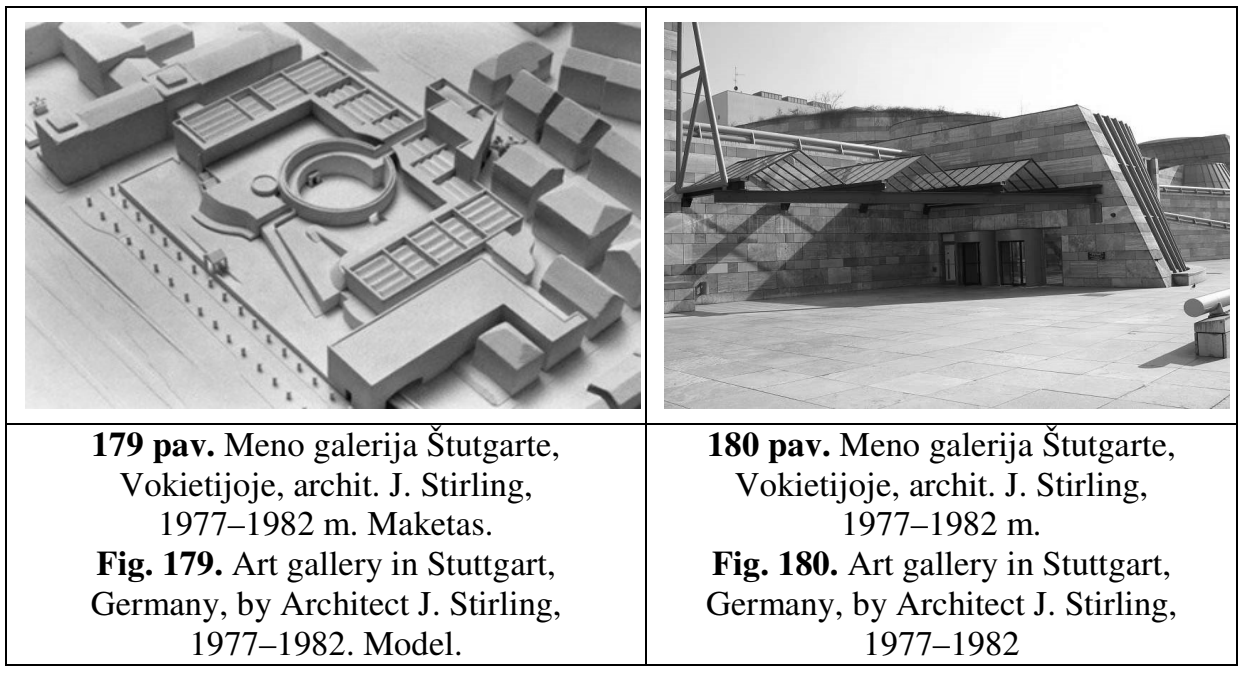

\begin{tabular}{|l|l|}
\hline 181 pav. Prekybos kompleksas Šeškiné, & 182 pav. M. Žilinsko dailès galerija \\
Vilniuje, archit. G. Baravykas, & Kaune, archit. E. Miliūnas, K. Kisielius, \\
G. Ramunis, K. Pempe, 1978-1985 m. & S. Juškys, 1981-1988 m. \\
Fig. 181. Shopping Complex Šeškine, in & Fig. 182. M. Žilinskas Art Gallery in \\
Vilnius, by Architects G. Baravykas, & Kaunas, by Architects E. Miliūnas, \\
G. Ramunis, K. Pempe, 1978-1985 & K. Kisielius, S. Juškys, 1981-1988 \\
\hline Vienam,
\end{tabular}

Viename ryškesnių Lietuviškojo postmodernizmo pavyzdžių - M. Žilinsko dailès galerijoje (archit. E. Miliūnas, K. Kisielius, S. Juškys 1981-1988 m.) (182 pav.) i komplekso gilumą įtrauktas iejjimas suformuoja vidini galerijos kiemą, kuris išsidèstęs aukščiau gatvès lygio, todèl ypatingą simbolinę reikšmę čia atlieka laiptai. Galerija pasižymi postmodernizmui būdingais elementais ašine kompozicija, iejjimo akcentavimu, kolonomis ir portiku. İejimo laiptai, pirmo aukšto kolonos apdailinti tamsiai rudos spalvos akmens plokštemis vizualiai atkelia ekspozicijų sales - stačiakampio gretasienio formos tūrius nuo 
žemès. Monumentalios formos taip pat pažymimos faktūra. Komplekso tūrinèje išraiškoje galima pastebèti Antikinès architektūros formų interpretacijas stilizuotas iejjimo portalas, stilizuotos kolonados, išraiškingos vidaus erdvès ir apdailos medžiagos. Galerijos pastatas nepasižymi kontekstualumu aplinkiniam užstatymui, čia jis kuria autonomišką postmodernistinę erdvę.

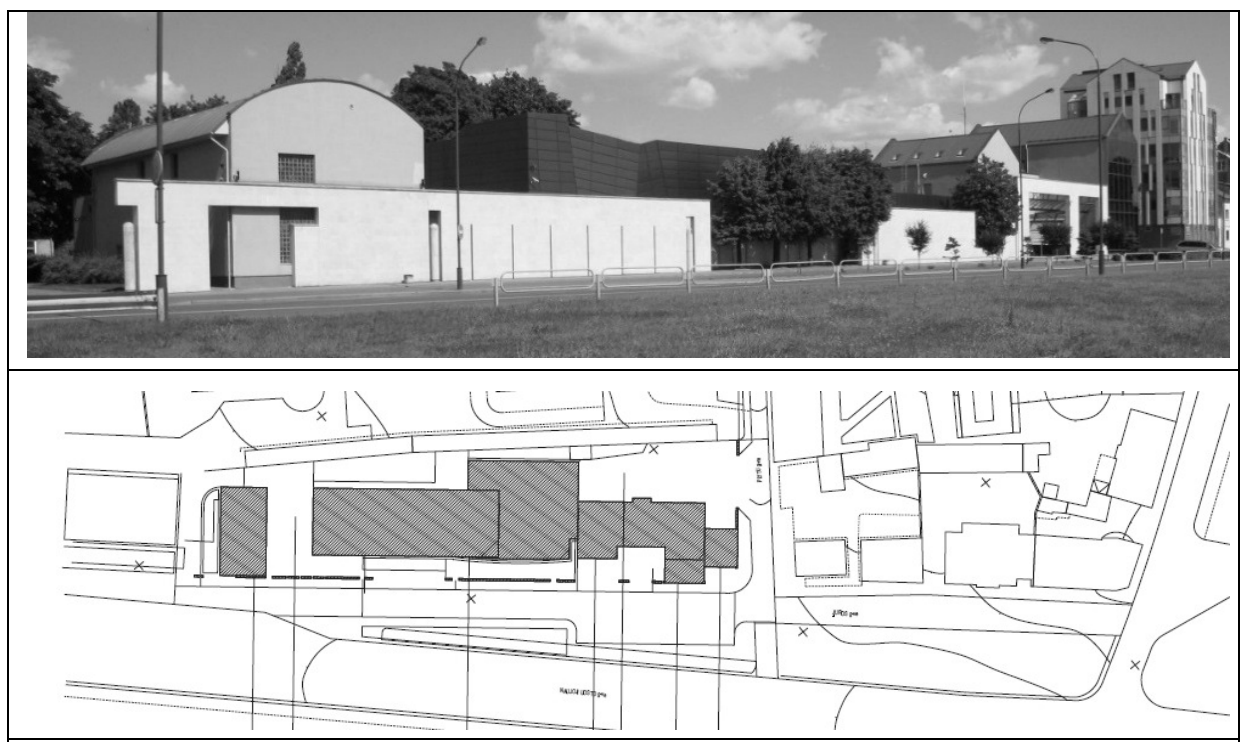

183 pav. Lietuvos banko administracinis pastatas ir saugykla Klaipedoje, archit. J. Volungevičius, R. Lajus, $1996 \mathrm{~m}$.

Fig. 183. Office building and vault of Lithuanian Bank in Klaipeda, by architects J. Volungevičius, R. Lajus, 1996

Stilizuota senamiesčio gatvelès interpretacija matoma J. Volungevičiaus ir R. Lajaus Lietuvos banko administracinio pastato ir saugyklos projekte, Klaipedoje (1996 m.) (183 pav.). Šiame objekte, kaip ir anksčiau aptartame Krašto apsaugos ministerijos centrinio gynybinio štabo komplekse, vadovaujamasi buvusio užstatymo tūrine interpretacija. Tam pasitelkiami daugiaplaniai fasadai, kurie derinami su ganètinai chaotišku Naujojo uosto gatvès užstatymo charakteriu. Fasadų daugiasluoksniškumas nèra atsitiktinis, pirmasis sluoksnis žymi buvusias posesijas, antrasis - buvusius rekonstruotus pastatus. Pastato siluetas - kompleksiškas, čia galime įžvelgti ir pusapvalių ir griežtų geometrinių formų, taip pat ir dekonstrukcijos elementų. 


\subsection{Dekonstruktyvizmo ir minimalizmo tendencijos šiuolaikinèje Lietuvos architektūroje}

Kartu su istorinių formų interpretacijomis, stilizacija, kontekstualumu ir kitais postmodernistinio stiliaus bruožais, Lietuvos architektūroje pastebimi architektūrinès raiškos pokyčiai, susiję su emociniu architektūros suvokimu, simboliais ir metaforomis, sietinais su pasaulinèmis dekonstruktyvistinèmis ir minimalistinèmis tendencijomis.

Dekonstruktyvizmas ir judesio metafora. 1988 m. birželi, Niujorko (JAV) Modernaus meno muziejuje duris atvėré paroda pavadinimu „Dekonstruktyvistiné architektūra“. Šios parodos iniciatorius Phillip Johnson (MOMA ${ }^{13}$ muziejuje rengęs ir kitas įtakingas parodas „Mies van der Rohe“ (1947 m.) ir „International style“ (1932 m.)) kartu su pagalbininku Mark Wigley tuo pačiu išleido ir parodos katalogą, kuriame sudèti tuo metu populiarëjančių architektų Frank O. Gehry, Daniel Libeskind, Rem Koolhaas, Peter Eisenman, Zaha Hadid, Coop Himmelblau, Bernard Tschumi darbai. Kataloge M. Wigley atskiria dekonstrukciją nuo dekonstruktyvizmo, pastaraji terminą naudodamas naujajai, įtakingai architektūros krypčiai apibrèžti (Mallgrave 2008).

Dekonstruktyvizmo terminą reikètų kildinti iš struktūralizmo ir poststruktūralizmo analizès krypčių, todèl dekonstruktyvizme galime jžvelgti tiek vienai, tiek kitai krypčiai būdingų bruožų. Struktūralistinèje analizèje orientuojamasi kontekstą. Vienas ar kitas analizuojamas reiškinys suvokiamas kaip vienas iš ženklų, sudarančių bendrą vaizdą. Struktūralizmo tikslas - atskleisti to ženklo esmę ir atrasti jo vietą bendroje semiotineje sistemoje. Greitai pasidarè akivaizdu, jog vienas ženklas dažnai nieko nereiškia, jo reikšmė gali būti nustatyta tik ivertinus santyki su kitais ženklais ar ju sistemomis, ką teigè poststruktūralizmas. Vis dèlto, post-struktūralistai pripažino, nors bendra ženklu sistema ir egzistuoja, tačiau jos išaiškinti neįmanoma, todèl dekonstruktyvistai grịžo prie tiesioginès atskirų ženklų analizès, tuo pačiu ịvertindami kompleksiškumo svarbą (Abrams 1988). Dekonstruktyvizmą galima laikyti išsilaisvinimu iš tradicinio vakarietiško mąstymo, bandymą ištrūkti iš ịprastinio pasaulio suvokimo. Tai skatino kūrybiškumą ir naujų idejų atsiradimą mene ir architektūroje. Dekonstruktyvizmas pripažista daugialypiškumą, pliuralizmą atitoldamas nuo tradicinių vertybių (Stevens 2009).

Dekonstruktyvistinès idejos gali būti laikomos neracionaliomis, skeptiškomis, prieštaraujančiomis normoms, nehumaniškomis, taip pat net ir nihilistiškomis „dèl absoliutaus vertybių nuvertinimo“ (Bloom 1984). C. Norris cituoja kai kuriuos dekonstruktyvizmo kritikus, teigdamas, jog dekonstrukcija yra tarsi priešprieša natūraliam (žmogiškajam, ne vertybiniam) mąstymo būdui.

${ }^{13}$ Museum of Modern Art 
Dekonstravimas gali būti suprastas kaip nereikalinga komplikacija, prasmès ieškojimas ten, kur jos galbūt ir nèra. Vis dèlto, pagrindinis argumentas verčiantis abejoti dekonstruktyvistine logika, pasak C. Norris, yra tai, jog, jeigu viskuo galime abejoti ir niekuo negalime pasitikèti, tuomet tas pats galioja ir dekonstruktyvizmui. Jeigu joks objektas neturi prasmès, tuomet dekonstruktyvizmas - taip pat. Tuo požiūriu objektų dekonstravimas yra betikslis (Norris 1982).

M. Wigley teigia, jog iki dekonstruktyvizmo, architektūra buvo kuriama naudojant grynąsias architektūros formas - kubus, cilindrus, sferas, piramides ir pan., komponuojant šiuos elementus i ansamblius, stengiantis akcentuoti kiekvieno naudojamo elemento grynają formą, suteikti jam funkciją. Tokiu būdu visa kompozicija tampa architektūriniu ansambliu, sukurtu vadovaujantis nustatytais ar išmoktais principais. Šie principai garantuoja stabilumą ir funkcionalumą, struktūrinę harmoniją. Dekonstrukcija nèra atskirta nuo konstrukcijos, jos nereikètu suvokti, kaip „,iškonstravimo“. Ne kiekvienas objektas, naudojantis neįprastus, chaotiškus ir sudètingus konstrukcinius sprendimus yra dekonstruktyvistinis. Dekonstruktyvizmo tikslas - emociné itampa, kylanti iš disharmonijos, skaidymo, destabilizacijos, sukuriant kitokị požiūrị i konstrukciją, teigiantị, jog dekonstrukcija yra viena konstrukcijos vidinių savybių, užkoduota pačioje konstrukcijos sąvokoje. Dekonstruktyvistas, M. Wigley teigimu, yra kūrejas, savo darbuose akcentuojantis dilemas, kuriantis problemas, naudodamas grynąsias architektūros formas, tačiau čia yra svarbi jų deformacija, sankirtos, ittampa (Wigley 1988). Architektai „Coop Himmelblau“ teigia: ,architektūra turi liepsnoti““ (Mallgrave 2008).

Tai, jog šie M. Wigley pastebejjimai atspindi tiek dekonstruktyvistinès architektūros siekius tiek kūrybos principus, iliustruoja pačių šios krypties autorių išdestyti kūrybos tikslai. Bernard Tschumi straipsnyje „The Violence of Architecture" (2008) nagrinèja architektūrinio objekto įtaką supančiai aplinkai. B. Tschumi teigia, jog tiek modernistinè, tiek postmodernistinè architektūra buvo brutuali tiek aplinkos, tiek architektūros vartotojo - žmogaus atžvilgiu, todèl, kad objekto (architektūros) ir subjekto (žmogaus) santykis su aplinka skiriasi. Stengiantis juos sujungti i vieną gaunama elementari konfrontacija, kuri automatiškai sukuria įtampą. Ši konfrontacija yra fundamentali ir neišvengiama, bet „,būtina, kaip sargybiniui reikalingas kalinys, kaip policininkui - nusikaltèlis, kaip gydytojui - pacientas, kaip tvarkai reikalingas chaosas“. Vienas demuo, be kito dèmens egzistuoti tiesiog negali, todèl architektūroje visuomet bus įtampa, tačiau dekonstruktyvistai tai akcentuoja, paverčia pagrindine pastato ideja. 


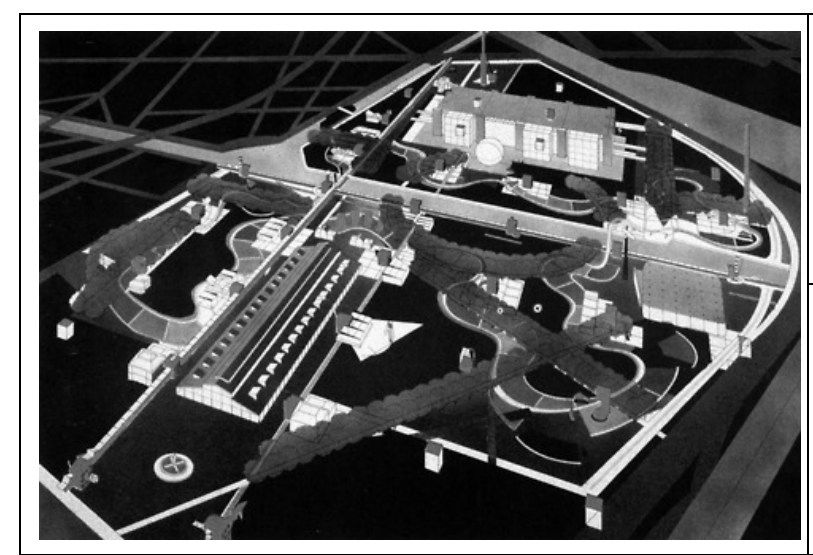

184 pav. Parc de la Villette Paryžiuje, Prancūzijoje, archit. B. Tschumi, 1985 m. Projektas.

Fig. 184. Parc de la Villette in Paris, France, by Architect B. Tschumi, 1985 m. Project.

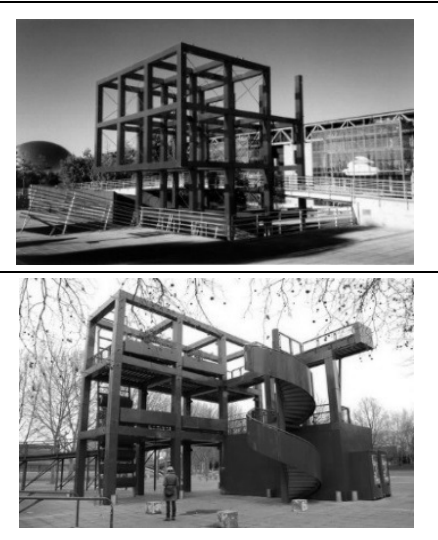

185 pav. Parc de la Villette

Paryžiuje, Prancūzijoje, archit. B. Tschumi, $1985 \mathrm{~m}$.

Dekoratyvios pastogès.

Fig. 185. Parc de la Villette in Paris, France, by Architect B. Tschumi, 1985 m. Follies.

1985 m. B. Tschumi pakvietè prancūzų filosofą, dekonstruktyvios semiotinès analizès pradininką, Jacques Derrida dalyvauti parko (Parc de la Villette) dalies Paryžiuje, Prancūzijoje, projektavime (184 pav.). Parko dalis, apimanti naujų muziejų pastatus, ekspozicijų sales atrodo tarsi būtų tikslingai suprojektuota, siekiant patikrinti dekonstruktyvistines teorijas. B. Tschumi pateiktame plane dekoratyvios pastogès (angl. Follies) $)^{14}$, išreikštos atviros konstrukcijos raudonais kubais, kurie patys jau yra deformuoti, taip sustiprinant jų formos autonomiškumą ir nekontekstualumą. B. Tschumi teigia: „tai architektūra, kuri nieko nereiškia“, ji skirta tam, kad prieštarautų lūkesčiams (Culler 2007).

Parko architektūrinė raiška susilaukè nemažai kritikos visų pirma dèl žmogiškojo mastelio. Atsiveriančios neužpildytos erdvės tarsi prieštarauja tam, ko parko lankytojas tikètųsi iš parko mieste. B. Tschumi projektas yra universalus, skirtas bet kuriai erdvei, visiškai nekreipiant demesio ì susiklosčiusi istorini užstatymą (Tschumi 1987a). Parko architektūrinè raiška siekia panaikinti bet kokius konkrečios vietos ženklus, grižta prie moderniajai architektūrai būdingo „erdvès“ koncepto, panaikindama postmoderniajai būdingą „vietos“. Erdvès konceptas būdingas B. Tschumi kūrybai, kadangi tai leidžia išgryninti subjekto ir objekto santyki architektūroje, nekreipiant dèmesio i aplinkinius faktorius (Papadakes 1988). Šio parko planinè struktūra, skulptūriški tūriai nekuria

${ }^{14}$ Folly (angl.) - dekoratyvi konstrukcija, kurios funkcionalumas yra antrinė paskirtis 
kontekstualios aplinkos, nereaguoja $\mathfrak{i}$ istorinị užstatymą. Parko architektūrinè raiška atspindi pirminius architektūros tikslus, išreikštus dekonstruktyvistine raiška, - susikoncentruoti ị veiklą, atliekamą konkrečioje erdvejje. Šis parkas nèra gražus reginys, kaip, pavyzdžiui, Centrinis parkas Niujorke (JAV), šio parko aplinka veikia tarsi fonas, papildantis kokią nors kitokią veiklą (Tschumi 1987a).

Nors dekonstruktyvistinè filosofija visų prima pastebima parko planinejje struktūroje, tačiau tai patirti įmanoma tik žvelgiant ị parką iš paukščio skrydžio. Lankytojams geriausiai pastebimi dekonstruktyvistiniai elementai yra minètosios dekoratyvios pastogès. Dažniausiai suvokiami kaip XVIII-XX a. pradžios parkų mažosios architektūros elementai, šios pastogès čia interpretuojamos ir pateikiamos kaip dekonstruktyvistiniai elementai. Funkcine prasme šie objektai yra skirti daugiau kaip orientyrai, padedantys orientuotis didelejje parko erdveje. Nors šie architektūriniai elementai ir neturètų turèti sąsajų su kontekstu ar prieš tai buvusiais pastatais, galima izžvelgti ryši tarp jų konstrukcijos ir toje vietoje stovejjusių industrinių, metalo karkaso pastatų. (Hill 1996).

Vienu pirmujų dekonstruktyvistinès raiškos bandymų Lietuvos architektūroje galima laikyti Kauno IX forto memorialinio komplekso projektą (archit. G. Baravykas 1983 m.) (186 pav.). Nors kai kurių architektūros tyrinètojų šis kompleksas ịvardinamas kaip struktūralistinis: „Šiu pastatų vidaus struktūra yra geometrinè, sukurta analitiškai skaidant, bet ne dekonstruojant pasirinktą figūrą. Iš pirmo žvilgsnio IX forto muziejaus pastatas gali priminti dekonstrukciją, tačiau eksterjeras tik atspindi painią statinio vidaus sandarą, kuri suformuota aplink centrinę muziejaus patalpą. Tai - struktūralistinis sprendimas“ (Gerliakas 1996a), tačiau sunku nepastebèti, jog būtų sudètinga vertinti atskirus elementus kaip vienetus, kadangi akivaizdu, jog visuma čia yra svarbesnè, tai post-struktūralistinis sprendimas. Dar svarbesne čia yra visumos kuriama emocinė i̇tampa, kuri kyla iš atskirų elementų tarpusavio ryšio. İspūdi sustiprina pasirinktos formos charakteris ir jų išdèstymo būdas. Aštrūs tūriai jungiami tarpusavyje ịkertant juos viena i kitą, išdèstant puslankiu tarsi vẻduoklę, taip dèmesį koncentruojant ị vieną emocinį tašką - centrinę muziejaus patalpą. Muziejaus korpusas vingiuojančiu, laužytu taku sujungtas su skulptūrine kompozicija, kuri tarsi išlaisvina šio komplekso emociją. Kauno IX forto naujasis muziejaus kompleksas, tai post-struktūralistinis visumos suvokimas papildytas dekonstruktyvistiniais architektūrinès formos kūrimo principais.

Dekonstruktyvistiniu sprendimu pastebima ir postmodernizmo laikotarpiu, tarp eklektiškų, dekoratyvių, kičinių formų. Savita dekonstruktyvistinès, hightech ir istorinių formų stilizacijos samplaika pasižymi ,Žirmūnų“ prekybos centro priestatas Vilniuje (archit. L. Merkinas 1997 m.) (187 pav.). „Plano erdvinè struktūra yra plastiška ir poetiška, buvusiam kietam tūriui priešinama minkštų kreivų linijų erdvių geometrija, Statiškos ir monotoniškos pastato dėžutės išraiška esmingai keičiama. Didžiulè išgaubta stiklinè plokštuma ,praplèšia“ kietą kevalą 
ties centriniu vestibiuliu ir pereina i plastišką stogo formą. Tektoninès konstrukcijos estetizavimas išryškèja kreivų linijų stogą laikančiose erdvinėse ažūrinèse santvarose. Savo plastiška dinamika ir lengvumu jos sudaro kontrastingą dermę su statiškomis ir monumentaliomis kolonomis. <...> Kompoziciniu požiūriu „Žirmūnų“ centro architektūra yra polifoniška. Jame ị vieningą visumą pavyko harmoningai sujungti kituose objektuose naudotus architektūrinès raiškos būdus“" (Markejevaitė 1998).
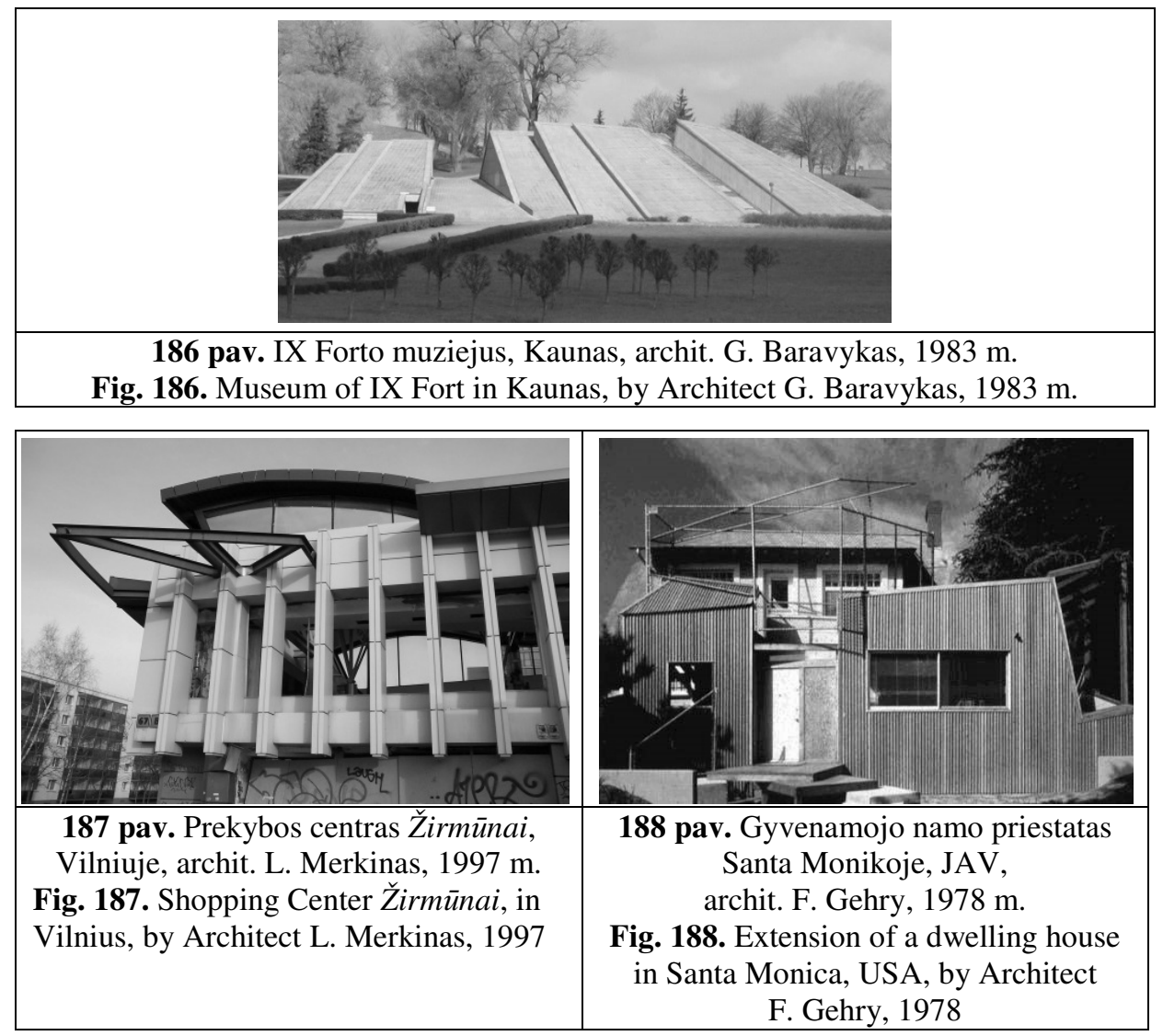

Nors šis priestatas ir nefunkcionuoja kaip savarankiška architektūrinè forma, ši naujo ir seno samplaika yra labai įdomi tyrinejjant architektūros stilių įtaką architektu kūrybai. Kartu su postmodernistine estetika ir kontekstualumu (kas postmodernizme užemè didelę dali priežastingumo), ì Lietuvos architektūrą atkeliavo ir dekonstruktyvistinis maištavimas. Buvo eksperimentuojama visomis galimomis raiškos priemonėmis, ieškoma tūrių ir plokštumų santykio, sudėtingų planinių sprendimų, erdvinių asociacijų su visiškai ne architektūriniais objektais, visa tai paryškinama atvirų konstrukcijų žaismu tiek viduje tiek išoreje ir taip pat 
gausybe apdailos medžiagų. Frank Gehry projektuodamas individualaus namo priestatą (188 pav.) tarsi tyčiojasi iš M. van der Rohe kūriniams būdingų tvarkingų plokštumų ir kampų. Išeksponuota konstrukcija, langai ir grotos iškraipyti, stiklinės detalès pakreiptos kampu (Jencks 1982). Šie konkretūs atvejai iliustruoja Venturiškają „,dekoruotos pastogès“ sampratą, kadangi pastatų forma, struktūra ir erdviniai sprendimai lieka nepakitę, tačiau dekonstruktyvistinis apvalkalas vizualiai įtakoja architektūrinę formą, keičia jos kontūrą.

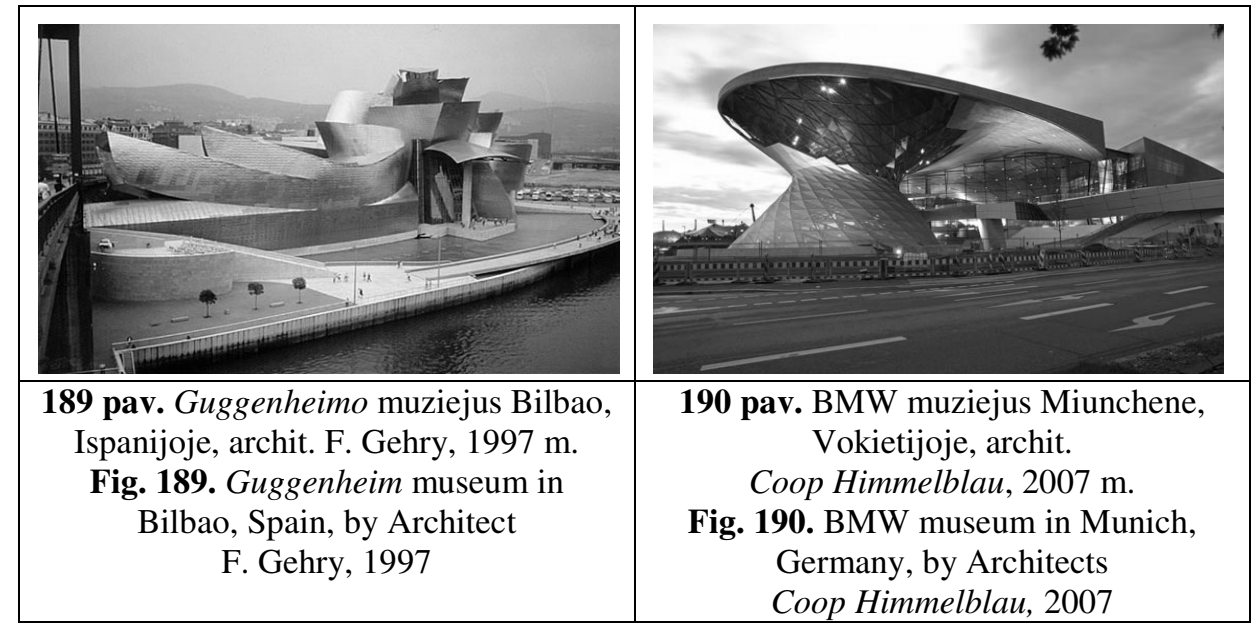

Skulptūrinių, iracionalių formų paieškos sustiprejo paskutiniojo XX a. dešimtmečio architektūroje. Atsiradus, vèliau masiškai išplitus kompiuterinèms technologijoms, formos transformacijos galimybès neregètai išsiplète, visuotiné kompiuterizacija, naujų instrumentų atsiradimas sudaro praktiškai neribotas naujų formų paieškos galimybes (Lupeikis 2007). Architektūros tyrinètojai svarbiu faktoriumi kompiuterinių technologijų taikymui architektūroje laiko būtent dekonstruktyvizmą. Šios architektūrinès krypties dèka, kompiuterinių technologijų taikymas atvèrè dideles raiškos galimybes (Melvin 2008).

Tai, visų pirma pastebima vėlesnejje Frank Gehry kūryboje. Salamono Guggenheimo muziejaus projekte Bilbao, Ispanijoje, F. Gehry dekonstruktyvizmas igauna amorfinių, organinių formų (189 pav.). Iš pirmo žvilgsnio pastatas atrodo tarsi sunkus urbanistinis augalas. Iracionalios, bioninių formų struktūros tarsi ropščiasi ant tvarkingų, stačiakampių urbanistinių formų. Pastato konstrukcija - neįikètinai sudètinga, projektavimo eigoje jau naudotos kompiuterinès technologijos (Jencks 1997). Panašūs formos modeliavimo sprendimai pastebimi ir kituose F. Gehry darbuose, pavyzdžiui, koncertų salëje Los Andžele, JAV (2005 m.), gyvenamuju namų projekte Diuseldorfe, Vokietijoje (1999 m.) ir kt. (Gilbert-Rolfe 1999). Šiuolaikinejje architektūroje dekonstruktyvizmo srovei taip pat priskiriami tokie architektai kaip Coop Himmelb(1)au (190 pav.), Morphosis, Z. Hadid, M. Fuksas. 


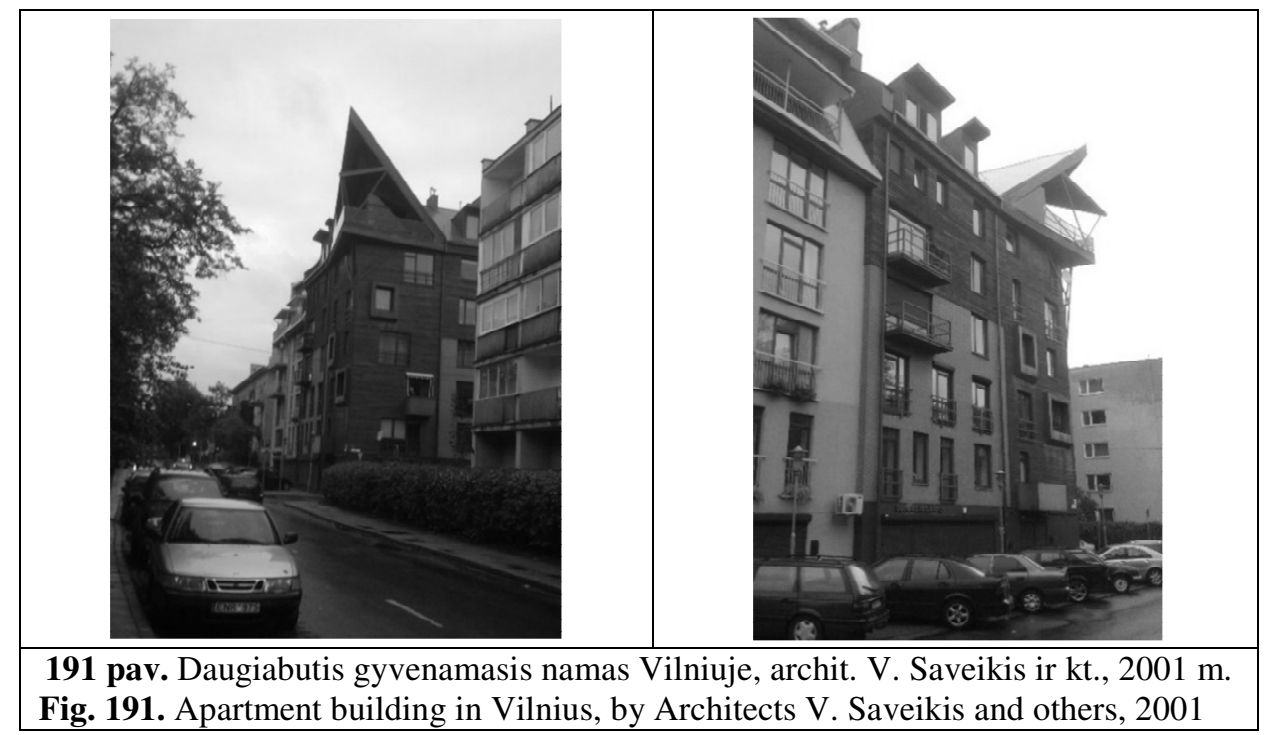

Fragmentiškos dekonstruktyvistinès architektūros apraiškos pastebimos ir pirmojo XXI a. dešimtmečio Lietuvos architektūros objektuose, dažnai dekonstrukcinius elementus naudojant kaip papildomus elementus vizualiai praturtinti architektūrinę raišką. Pavyzdžiui, daugiabučio namo projekte Latvių g. Vilniuje (archit. V. Saveikis, R. Malavickas, R. Mankus 2001 m.) matomas sudètingas, fragmentuotas pastato tūris, kurio nevienalytiškumą pabrèžia skirtingos apdailos priemonès, užbaigiamas sudètinga, laužyta stogo konstrukcija, formuojančia komplikuotą architektūrinès formos kontūrą. Šiuo atveju laužytos stogo plokštumos neveikia vidinių erdvių charakterio, tuo pačiu neįtakoja ir pastato funkcijos, tačiau architektūrinei formai suteikia dekonstruktyvų charakterị (191 pav.). Vienbučio gyvenamojo namo Panevėžyje projekte (archit. „Arches“ 2005 m.) sudètingos konfigūracijos forma naudojama racionalaus tūrinio ir funkcinio sprendimo kontekste, taip sukuriant intrigą vienoje iš pastato interjero erdviu (192, 193 pav.). Skirtinga ne tik pačios formos konfigūracija, tačiau ir jos medžiagiškumas, tekstūra. Šiame objekte įtampa kuriama priešpastatant skirtingo prado formas, kaip akcentą naudojant pati jų susikirtimo faktą. Išraiškingas, dekonstruktyvistinei architektūrai būdingas elementas naudojamas ir anksčiau aptartame „Swedbank“ banko pastate, Vilniuje (archit. A. Ambrasas 2009 m.). Laužytos formos terasa naudojama metaforiškai, tarsi banguotų Neries pakrančių stilizacija.

Dekonstruktyvizmui būdingu, kompleksišku ịvairių pirminių architektūrinių formų derinimu pasižymi sveikatingumo centro kompleksas Ozo g. Vilniuje (archit. L. Vaitys 2000 m.). Siekiant pabrèžti šią kompoziciją, skirtingų formų apdailai parenkamos skirtingos medžiagos. Panašus sprendimas, tiesa su kiek 
imantresniais, high-tech architektūrai būdingais elementais pastebimas ankstesniame skyriuje minèto prekybos centro „Laisvë“ (buv. „SBA baldai“) pastate Vilniuje (archit. S. Kuncevičius, A. Jakutis 2000 m.). Dekonstruktyvistinė architektūros raiška administracinès paskirties pastate Kaune (archit. G. Natkevičius, V. Kuliešius 2001 m.) (194 pav.) taip pat išreikšta ịvairiu geometrinių formų derinimu, tačiau čia jaučiama postmoderniajai architektūrai būdinga kontekstualumo paieška ir tam tikra ironija. Langų ritmas gatvès fasade atkartoja aplinkinio užstatymo charakterí, tačiau pakreiptos langų angos pabrèžia ikirsto, netaisyklingo laiptinès cilindro formą. Geltonos spalvos balkonų tūriai derinami prie aplinkinių pastatų balkonų, tačiau banguojanti jų forma savo charakteriu vẻl gražina prie cilindro formos laiptinès akcento.

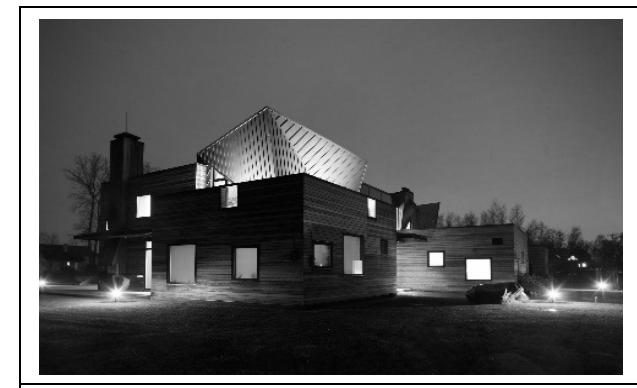

192 pav. Gyvenamasis namas

Panevėžyje, archit. ARCHES, $2005 \mathrm{~m}$.

Fig. 192. Dwelling house in Panevėžys, by Architects ARCHES, 2005

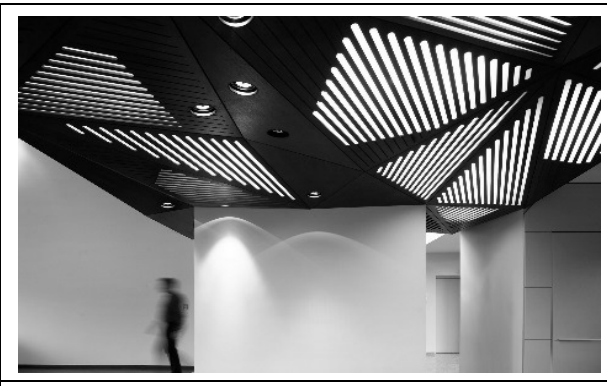

193 pav. Gyvenamasis namas Panevėžyje, archit. ARCHES, $2005 \mathrm{~m}$. Interjeras.

Fig. 193. Dwelling house in Panevėžys, by Architects ARCHES, 2005. Interior.

Pirminių geometrinių formų deformacijos, būdingos dekonstruktyvistinei architektūrai, pastebimos vėlesniuose Lietuvos architektūros pavyzdžiuose. Daugiabučio gyvenamojo namo projekte Vilniuje (archit. „Plazma“ 2006 m.) trys masyvūs „mediniai“ tūriai deformuojami juos įlenkiant, ir apjungiami stiklinèmis holo patalpomis. Šiame objekte nèra dekonstruktyvistinei architektūrai būdingų sankirtų, tačiau tūrių deformacijos išlieka. Šiuo atveju adaptuojamas dekonstruktyvizmo santykis su geometrine forma, tačiau ne jų derinimo principais (195 pav.). Analogiški sprendimai tūrių deformacijos atžvilgiu pastebimi gyvenamojo namo Kaune (archit. R. Raslavičius 2010 m.) (196 pav.), gyvenamuju namų komplekse Kaune (archit. V. Adomavičius 2010 m.), gyvenamojo namo Birštone (archit. G. Natkevičius, 2011 m.) architektūriniuose sprendimuose (197 pav.).

Išskirtiniu tūrio deformavimo pavyzdžiu galima laikyti gyvenamojo namo Kaune projektą (archit. G. Natkevičius, 2010 m.) (198 pav.). Šiuo atveju du atskiri korpusai - bendrujų erdvių (virtuvè, valgomasis, svetainè) ir miegamųjų, sujungiami per pagalbines patalpas, garažą ir holą. Taip suformuojamas pusiau 
atviras vidinis kiemas, suteikiantis privatumo. Dviejų korpusų sujungimo vietoje netaisyklingas pastato tūris dar labiau sulankstomas, pastato kontūras tampa tarsi sulaužytas. İspūdžiui sustiprinti naudojama rūdinto metalo apdaila, kurio profiliai tvirtinami įstrižai.

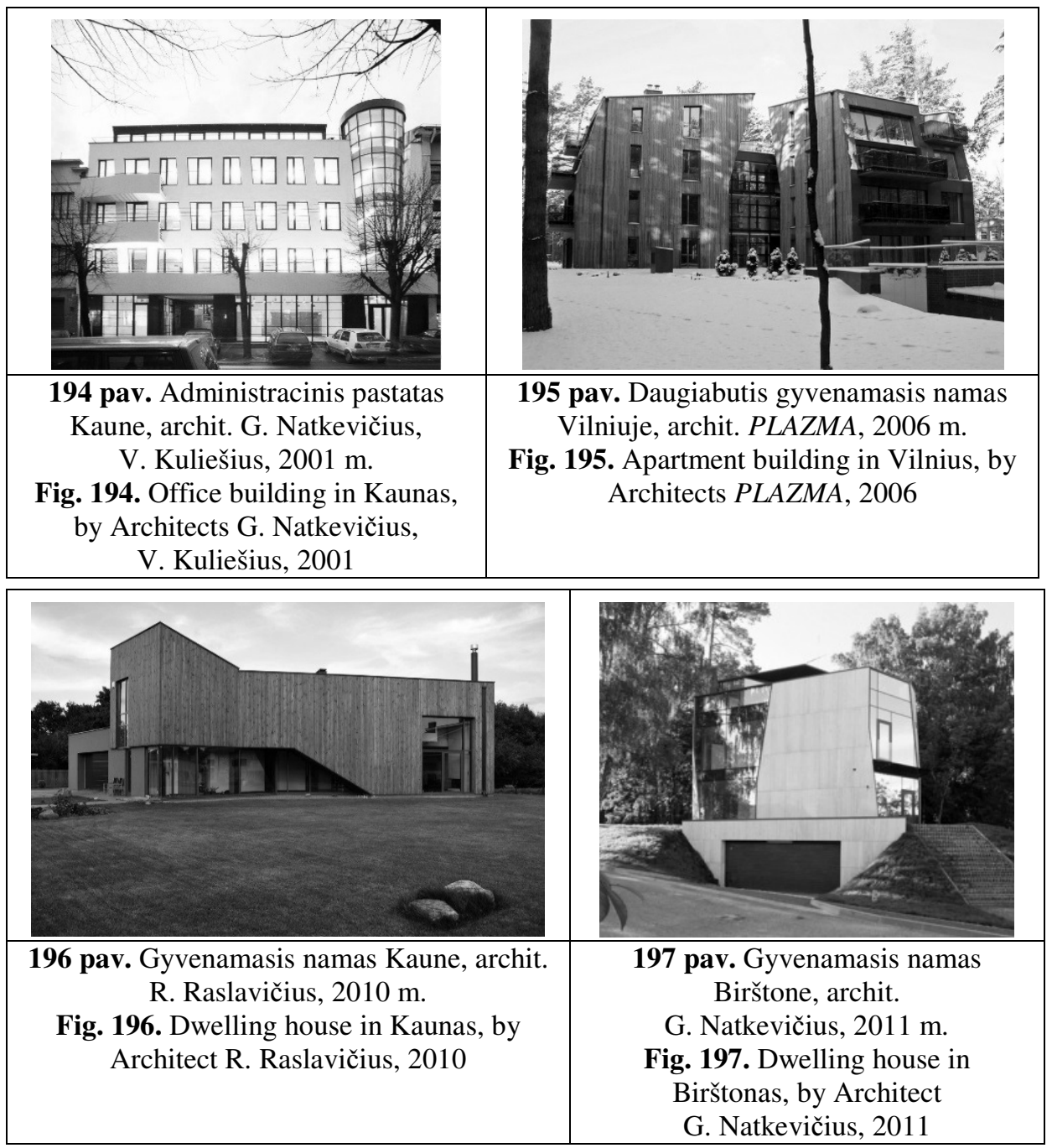




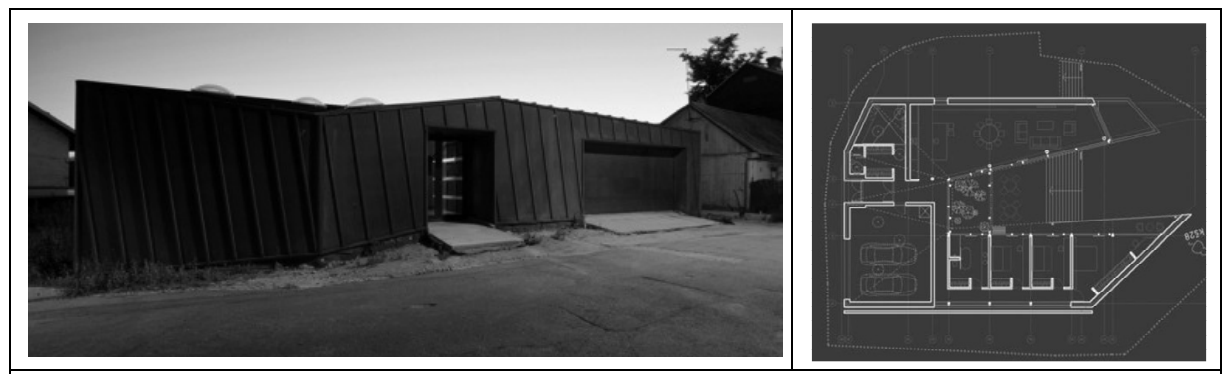

198 pav. Gyvenamasis namas Kaune, archit. G. Natkevičius, 2010 m.

Fig. 198. Dwelling house in Kaunas, by Architect. G. Natkevičius, 2010

2013 m. realizuotas Mokslinès komunikacijos ir informacijos centras Saulètekyje, Vilniuje (archit. R. Palekas, B. Puzonas, A. Palekienè ir kt.) (199 pav.) pasižymi monumentaliais, deformuotais tūriais turinčiais aliuzijų i gamtines formas - uolienas ar kristalus. Trys skirtingos konfigūracijos tūriai sujungiami stiklinèmis holo - atriumo patalpomis, kurios tuo pačiu sukuria pusiau atvirą, su pušynu besiribojanti vidini kiemą. Komplikuota tūrinè komplekso išraiška interjeruose tampa funkcionaliomis bibliotekų ir skaityklų erdvemis. Apdailai naudojamos pilkai gelsvos keramikinès plokštelès derinamos su betonine prieigu danga pabrèžia ryšio su gamtinėmis formomis paieškas. Bibliotekos komplekso architektūrinè raiška priklauso šiuolaikinio dekonstruktyvizmo krypčiai, kurią yra priimta vadinti kristalų formos ${ }^{15}$ architektūra (Jencks 2011), kildinamai iš D. Libeskind projektuoto naujojo gamtos muziejaus korpuso Toronte, Kanadoje (2007 m.), pavadintu „Kristalas“ (200 pav.). İstrižai komponuojami vienas į kitą panašūs sudėtingos formos tūriai, kurie apdailinti aliuminio plokštelèmis, primenančiomis faktūrą, aptinkamą ant suskilusio kvarco. Lygiagrečiai, arba kaip tik, priešingai formos pasvirimo krypčiai išdèstomos panašių kontūrų langų plokštumos. Pastato tūriai pasvyra virš gatvès, siekiant panaikinti ribą tarp vidaus erdvių ir išorès. Panašus tūrinis sprendimas igyvendintas Honkongo universiteto, kūrybinių medijų centro pastate Kinijoje (archit. D. Libeskind, 2010 m.) (201 pav.), taip pat Denverio meno muziejuje (archit. D. Libeskind, 2006 m.), kino salių pastate, „Futuroscope“ parke Prancūzijoje (archit. G. Buthaud 2004 m.), polifunkciniame pastate Londone, Anglijoje (archit. „Wilkinson Eyre architektai“ 2012 m.), kino teatru centre Dresdene, Vokietijoje (archit. „Coop Himmelb(1)au“, 1993-1998 m.) (202 pav.), ir kt.

Daniel Libeskind architektūros sieki sukurti ịtampą, sieja su simbolių ir ženklų perteikimu architektūrinès raiškos pagalba, tuo pačiu įvesdamas ir laiko dimensiją. D. Libeskind architektūrai svarbi judesio metafora, inercija, kurią sukuria pirminès geometrinès formos jas transformuojant. Erdvès suvokimas

15 angl. Chrystal-shaped 
tokioje architektūroje kinta, erdvè tampa daugialype, fragmentuota, pastoviai kintančia ir evoliucionuojančia. Tokiu būdu architektūrinè forma apibrěžiama ne tik vizualiai, bet pasitelkus metaforas, simbolius ir ženklus.

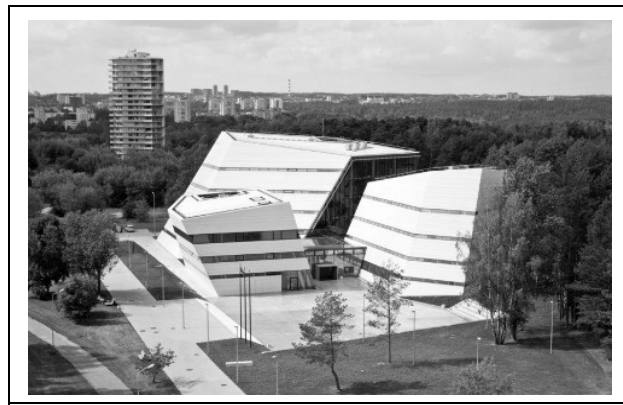

199 pav. Mokslinès komunikacijos ir informacijos centras Vilniuje, archit.

R. Palekas, A. Palekiené,

B. Puzonas, $2013 \mathrm{~m}$.

Fig. 199. Center of Scientific comunication and information in Vilnius, by Architects R. Palekas, A. Palekienè, B. Puzonas, 2013

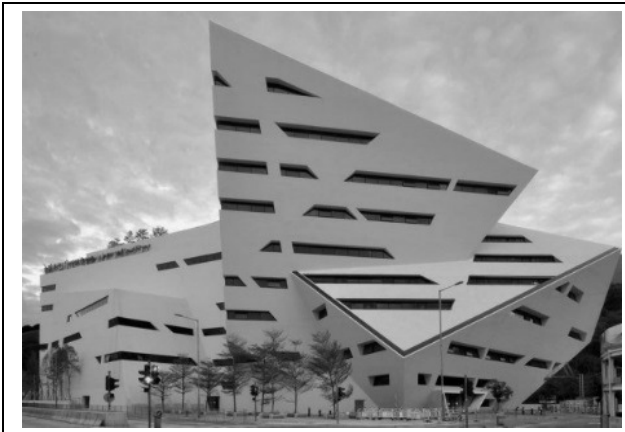

201 pav. Honkongo universiteto kūrybiniu medijų centras Kinijoje, archit.

D. Libeskind, $2010 \mathrm{~m}$.

Fig. 201. Center of Creative Media, Hong Kong University, China, by Architect D. Libeskind, 2010

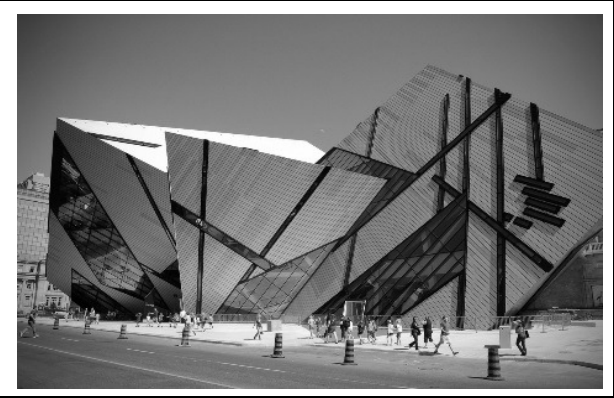

200 pav. Gamtos muziejus Toronte, Kanadoje, archit. D. Libeskind, $2007 \mathrm{~m}$. Fig. 200. Nature Museum in Toronto, Canada, by Architect D. Libeskind, 2007

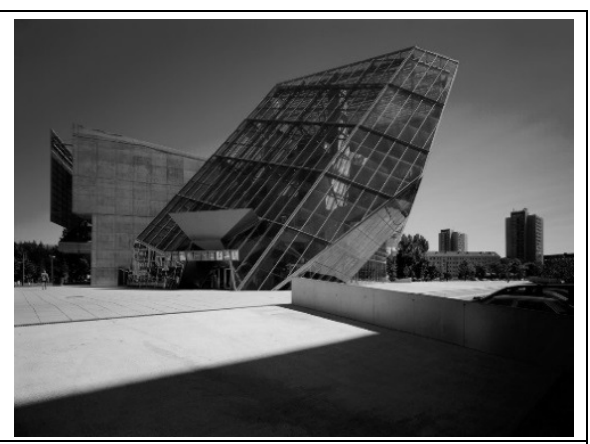

202 pav. Kino teatrų centras Dresdene, Vokietijoje, archit. Coop Himmelb(l)au, 1993-1998 m.

Fig. 202. Cinema Ceter in Dresden, Germany, by Architects Coop Himmelb(l)au, 1993-1998

Judesio metafora nèra išskirtinai šiuolaikinès architektūros konceptas. 1905 metais pasirodė Alberto Enšteino veikalas „Apie judančių kūnų elektrodinamiką“, kuriame pristatyta reliatyvumo teorija. Joje pristatyta keturiu dimensijų aplinka. Laikas ir erdvè nustojo būti laikomi nevienalyčiais, nesugretinamais. „<...> nepertraukiama keturių dimensijų įvairové nebebuvo skirstoma į trijų dimensijų erdvę ir vienos dimensijos laiką, kur vienalaikiškumas, ar sinchroniškumas galèjo 
būti vertinamas tik iš laiko perspektyvos, t. y. vertinant praeitị. Priešingai, laiką priimta laikyti reliatyviu ir tiesiogiai priklausančiu nuo erdvès. Laiko - erdvès sąvoka tapo vienalytė, neskirstoma $\mathfrak{i}$ atskiras dimensijas, nematuojama atskirais matmenimis“" (Kwinter 1986).

Pasikeitęs laiko suvokimas buvo sąlygotas teorinių atradimų, reliatyvumo teorijos paplitimo mokslininkų tarpe, tačiau XX a. pradžioje keitèsi ir žmones supančios erdvès samprata. Pasak S. Kwinter, itin reikšmingi technikos išradimai, ypač elektros energijos naudojimo protrūkis, lèmé didelius tyrinejjimus elektromagnetikos srityje. Radijo bangos, bevielis telegrafas, radijo paplitimas, masinè elektrifikacija ir pan., sąlygojo kitoki erdvès suvokimą. Pradèta manyti, kad realybė yra visgi kitokia, nei yra matoma. Kas anksčiau buvo laikoma tuštuma tapo apčiuopiama, aplink tvyranti erdvè prisipilde elektromagnetinių, radijo bangų. Suvokiant, jog tai, kas anksčiau laikyta tuštuma tapo užpildyta, atsirado kitokios meninès išraiškos poreikis (Kwinter 1986).

Vizualiuose menuose, ypač tapyboje, vyko panašūs procesai. Nuo XV a. pradžios vyravusi vienintelè paveikslo perspektyva buvo išstumta ịvairių asimetriškų formų ir tūrių kompozicijų, kurios gali būti tyrinèjamos iš įvairiausių perspektyvų. „Erdvè pradèta suvokti ne tik kaip vieta, kurioje vienokiu ar kitokiu principu išdèliojamos figūros, bet kaip organiškas procesas, kuomet judesys ir tūriai patys savaime kuria kompozicijas ir suteikia tam tikrus potyrius. <...> postimpresionistai, kubistai, ekspresionistai ir kiti menininkai sekè šia tendencija nuo pat XX a. pradžios. Cezanne'o natiurmortuose, Pablo Picasso paveiksluose kompozicijos išlaisvinamos nuo laiko sekos, atsiranda daug vietos interpretacijoms. Tapyboje, kaip ir architektūroje, atrandamas daugiasluoksniškumas, peršviečiamos plokštumos, objektas suskaldomas fragmentais, siekiant parodyti tiek vidų, tiek išorę. Vaizduojant objektą iš kelių perspektyvu vienu metu, tapyboje pradedama naudoti laiko dimensija“ (Heyer 1993). Architektūros tyrinètojas S. Giedion Enšteino reliatyvumo teoriją siejo su kubizmu, o kubistinès formos buvo lyginamos su Le Corbusier Villa Stein, tačiau nepaisant šio laiko - erdvès koncepto, šiame pavyzdyje erdvè vis dar išliko sukaustyta sienų (Tschumi 1975). Didelę ịtaką kubistiné lengvumo, judejjimo, kompozicijos atvirumo filosofija padare De Stijl judejimui (Habermas 1981). Architektas Gerrit Rietveld 1920 metais suprojektavo Schroderio namą, kuris puikiai atspindi atviros formos De Stijl estetiką (Heyer 1993). Panašią filosofiją galima įžvelgti tiek John Hejduk, tiek Michael Graves kūryboje.

Judesio interpretacijos samprata dekonstruktyvistų architektūroje pastebimos jos santykyje su kitomis meno sritimis. F. Gehry, kalbėdamas apie savo projektuotą baldu kompanijos „Vitra“ dizaino Muziejų (1989 m.) (205 pav.) Vokietijoje, paminèjo savoką ,,sustingęs judejjimas“. Akivaizdus F. Gehry pastatų panašumas ị konstruktyvistų ar ekspresionistų tapybos darbus yra būdingas 
dekonstruktyvistų architektūrai. Šių tapybos srovių ir architektūros susijungimas sukūrè kažką visiškai naujo. Jeigu klasikinis menas teigè rimti, nekonfliktiškumą, nerūpestingumą, tai šiuolaikinis menas siekia nustebinti žiūrovą, jis remiasi iracionalumu, netikètumu (Palaima 2006). Aaron Betsky dekonstruktyvistinius Z. Hadid darbus apibūdina kaip ,sprogusią izometrinę projekciją“ (204 pav.). Šio koncepto ištakos matomos kubistų siekyje sustabdyti laiką, tapybos kompozicijose apimti papildomą dimensiją. Akivaizdu, jog kubistinis M. Duchamp darbas „Nude Descending the Staircase“ (205 pav.) padare didelę ịtaką Z. Hadid kūrybai (Betsky 1998). Fragmentuoti tūriai, „sprogimo“, arba tiesiog judesio samprata $i$ architektūros, o taip pat ir i tapybos kalbą ịveda ketvirtos dimensijos sąvoką. Palaipsniui Kubizmo principus perèmé puristai (P. Mondriano kompozicijos) bei suprematistai (K. Malevich), kurių itaka vis dar jaučiama XX a. pabaigos architektų P. Eisenman, R. Meyer, R. Koolhaas kūryboje (Sennot 2004).

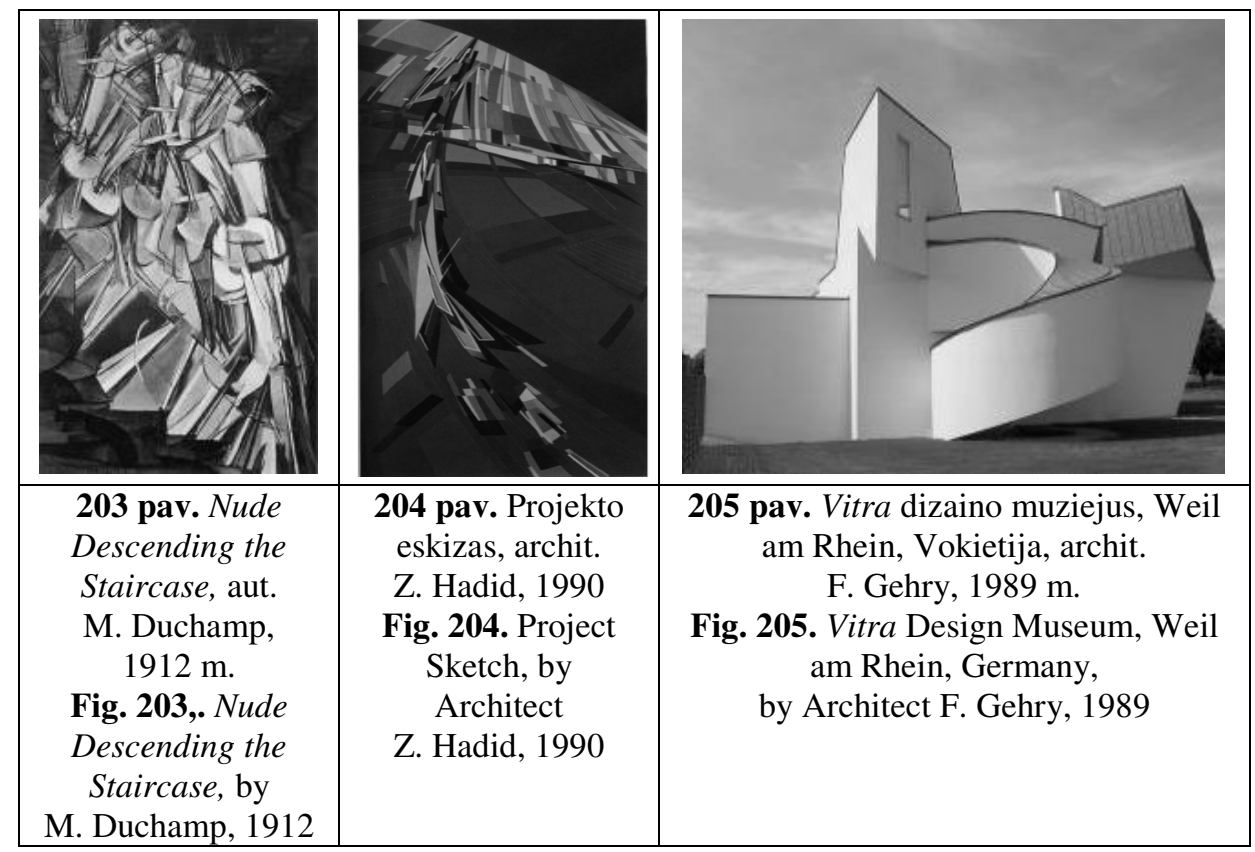

Architektai, noredami perteikti judesį savo kūriniuose dažnai apsiriboja formaliais kompozicijos principais. Judesys išreiškiamas dinamiškomis kompozicijomis, elementų pasikartojimu, ritmu, pauzèmis, tūrių deformacijomis ir pan. Formali, dinamiška ekspresija perteikia judesị netiesiogiai, simbolizuoja virtualu judesi, kitimą. Tiesioginis fizinis judejjimas, neskaitant tam tikrų techninių pastato elementų (liftų, inžinerinių sistemų), niekuomet nebuvo plačiai naudojamas. Tą pati galima pasakyti ir apie media priemonių, vaizdinių projekcijų, hiperpaviršių raišką pastato koncepcijoje. Priešingai - daugumos pastatų archtektūrinè raiška vis dar atrodo stabili, ,sunki“, nepajudinama ir 
statiška. Šiuolaikinëje architektūroje estetinių sprendimų, susijusiu su fiziniu, kinetiniu judejimu, pastebima vis dažniau. Naudojant šiuolaikines technologijas, technines inovacijas, ivvairūs formų transformacijos ieškojimai, hiperpaviršiu teorijos turi įtakos ne tik pastato funkciniams, bet ir estetiniams sprendimams. Tai iš esmès keičia vizualu pastato suvokimą. Ketvirtoji dimensija architektūroje pasireiškia tuomet, kai dinaminiai veiksniai, transformacija laike formuoja hiperpaviršius, kurie yra viena svarbiausių pastato meninių išraiškos priemonių, arba net pagrindinis jo konceptas.

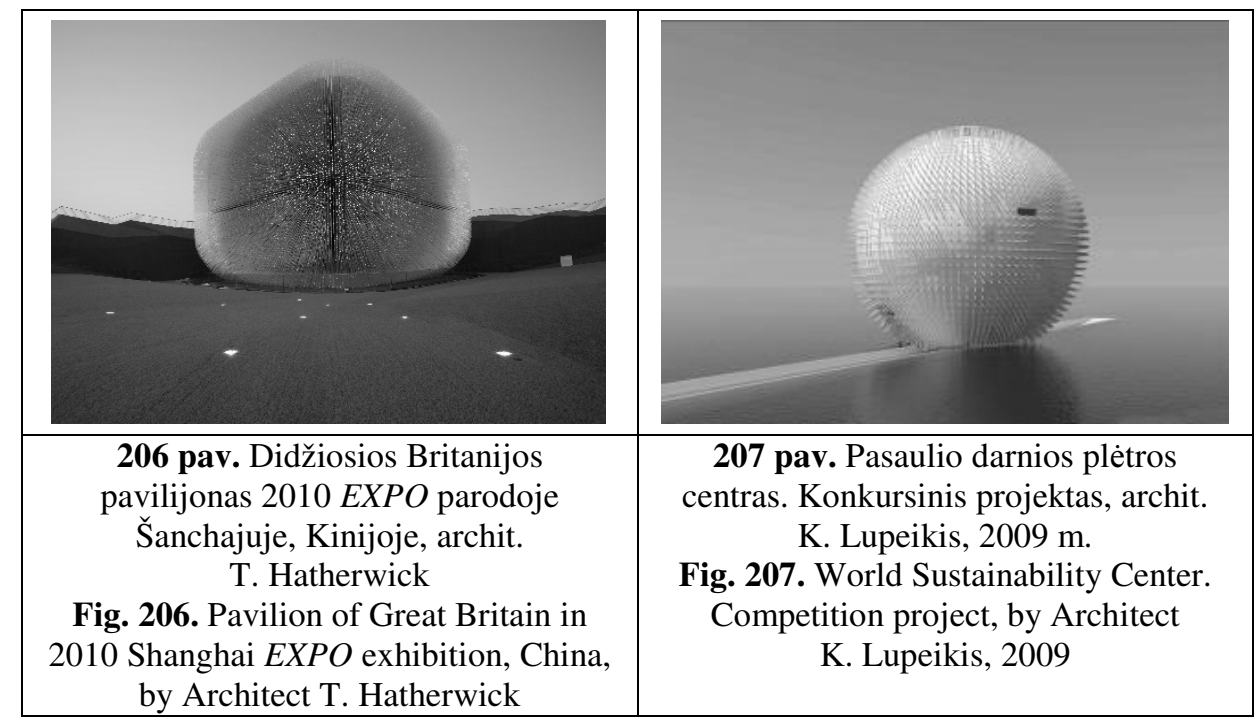

2010 metų Šanchajaus EXPO parodoje pristatyto Didžiosios Britanijos paviljono (arch. T. Hatherwick) pagrindinè idejja - lengvas, vos žemę liečiantis kubas, apvilktas 60 tūkst., 7,5 metrų ilgio vejjyje plazdančiais virbais, kurie taip pat yra ir viduje esančios ekspozicijos salès šviesos šaltiniai (206 pav.). „Dinamiškas Didžiosios Britanijos paviljono fasadas reaguoją i menkiausią vėjo dvelktelèjimą ištrindamas ribas tarp pastato ir judančios, gyvos skulptūros. Per plèvesuojančius permatomus vamzdelius i interjerą patenkanti dienos šviesa sukelia žvaigždèto dangaus ịspūdị, naktį mirkčiojantys šviesos elementai sukuria nepakartojamą efektą" (Chino 2010). Paviljono architektūrinè raiška, pastato forma kuria naują architektūros sampratą. Objekto idejjai perteikti neužtenka iprastinių vaizdinių priemonių, pasitelkiama animacija, video projekcijos.

Panašus sprendimas Lietuvos architektūroje, kompleksiškai perteikiantis judesio sampratą architektūrinejje raiškoje, galètų būti „Pasaulio darnios plètros centro" konkursinis projektas (archit. K. Lupeikis 2009) (207 pav.). Kaip teigia K. Lupeikis: „<..> projektas skirtas skatinti ir remti tyrimus atsinaujinančių energijos šaltinių srityje. Tarptautiniame konkurse buvo siekiama atrasti 
pavyzdinio vystomos veiklos simbolio įvaizdi. Pateikiamas pavyzdys konkursinis darbas „Sfera“, konceptualiai atspindi pagrindinę darnios plètros filosofiją per tobuliausią žmogaus sukurtą formą, kuri taip pat yra artimiausia gamtinèms formoms (lyginant su kubu, piramide, cilindru, etc.). Sfera - Saulès, gyvybès ir tobulumo simbolis, tai išskirtinio silueto ikona, ir vietinio konteksto kulminacinis taškas. Energetiškai pastatas aprūpinamas iš atsinaujinančių šaltinių - saulès, vejjo, jūros. Lankstūs fotoelementai „spygliai“ pietiniame Sferos pusrutulyje generuoja saulès energiją, taip pat energiją iš vejjo sukeliamos turbulencijos ir naudoja ją pastato funkcinèms reikmèmėms bei naktiniam eksterjero apšvietimui. Kuo stipresnis vejjas - tuo ryškiau šviečia sfera, tokiu būdu interaktyviai reaguodama i aplinką, gali kisti apšvietimo spalvos, piešinys, intensyvumas. Pastatas gali cikliškai keisti savo vietą virš bazinio panduso: vieną kartą ji galima matyti visai šalia, kitą kartą nutolusi 800 metrų atstumu. Ši daugiaplanė objekto kaita (paviršiaus, vietos) provokuoja žiūrovą susimąstyti apie visa ko laikinumą, suvokiamą ketvirtojoje dimensijoje" (Lupeikis 2011).

Minimalizmas. Minimalistinių formų gausu praejjusių epochų architektūroje, tačiau ši sritis suklestèjo XX a. antroje pusèje. Galima teigti, jog šiandien ši kryptis yra tiek sutvirtejjusi, jog yra tapusi masiniu reiškiniu, mados dalyku. Šiuolaikinio minimalizmo ištakos sietinos su rusų konstruktyvizmu, ypatingai paplitusiu XX-ojo amžiaus pradžioje, suprematizmu (K. Malevičius), modernistinès architektūros atstovų darbais, bauhauzu, septintojo dešimtmečio minimalistiniu menu. Šiuo laikotarpiu menininkai akcentavo pirminių struktūrų nagrinèjimą, kaip atsvarą ekspresionizmo ir kitų krypčių meniniam ,pilnumui““. Minimalistai sieke kurti paprastus, redukuotus darbus, ignoruojant dekoratyvias priemones. Minimalistinis menas siekė atkreipti dėmesị i stebètoją supanti formos ir erdvès santyki (Gadanho 2007). Prielaidas atsirasti minimalizmui suteike ir platesnis, ne tik meninis kontekstas, tai tam tikras gyvenimo stilius ir poreikiai, gyvenimo būdas ir mados supratimas (Lupeikis 2007). Architektūros tyrinètojo Ch. Jencks teigimu, minimalistai M. van der Rohe teigini „,mažiau yra daugiau“, pavertè teiginiu „kuo mažiau, tuo daugiau“. Minimalizmo riba buvo pasiekta kompozitoriui John Cage ịrašius kūrini, kuriame buvo visiška tyla. Tai tam tikras eksponavimas to, ko nèra (Jencks 1997).

Minimalistai 7-ajame ir 8-ajame dešimtmečiuose siekè išlaisvinti meninę kūrybą nuo jos vaizduojamojo ar dekoratyvinio pobūdžio, tam, kad pabrèžtu jos architektūrinę būklę. Prasmès kūrimas buvo perkeltas nuo objekto prie erdvès, esančios tarp žiūrovo ir objekto: dinamiškai suvokiamos zonos, kurią užpildo judantys kūnai. Minimalizmo menininkai siekè išeiti už struktūrinio ar kompozicinio modeliavimo ribų, ịtraukdami i savo darbus galerijos erdvę ir žiūrovus.

Minimalistinis menas negalèjo neturèti įtakos minimalizmo šiuolaikinèje architektūroje atsiradimui ir jo formaliajai raiškai, nors tai savo konceptualiu 
pagrindu nèra tapatūs reiškiniai. Šiuolaikinis minimalizmas mene pradejo reikštis septintajame praeito amžiaus dešimtmetyje, o tai būtu galima sieti su D. Judd, D. Flavin darbais, taip pat kai kurių skulptorių pasiryžimu atitolti nuo sudètingu ekspresionistinių kompozicijų, būdingų prieškario menininkams.

Dvidešimtojo amžiaus pabaigoje architektūroje pradeda reikštis visiškai naujos, tiek formos tiek koncepcijos prasme, minimumo idejos kurios daro ịtaką šiuolaikinès architektūros meninei raiškai. Šiuolaikinė architektūra pasireiškia daugybe ịvairiu judejjimų ir krypčių ịvairove. Paskutiniame XX a. dešimtmetyje architektūroje atsirado ir tokia kryptis, kuri buvo įvardinta kaip minimalizmas. Šiuolaikinis minimalizmas sutelkè demesị ir išgrynino ankstesnèse epochose naudotas minimalistines formas, išskyrè minimalizmą kaip savarankišką architektūrinès raiškos kryptị.

Minimalistiniai formos kūrimo principai užkoduoti pačiame pavadinime. Šios krypties architektūros koncepcija - supaprastinti viską iki pagrindinių kokybès parametrų, ir taip pasiekti paprastumą (Bertoni 2002). Visos objekto sudedamosios dalys minimalizuojamos iki tokio etapo, kai nieko daugau pašalinti ir tokiu būdu patobulinti objekto dizainą yra nęimanoma (Pawson 1996). Pagrindiniai minimaliosios architektūros formantai yra šviesa, forma, medžiaga, erdvé, vieta ir žmogaus santykis. Minimalistams svarbu ne tik fizinès pastato savybès, netgi priešingai, labiau dvasinès, kuriančios nuotaiką, būseną (šviesa, erdvè, aplinka, medžiaga) (Bertoni 2002). Tokios, kokybinès pastato savybès atskleidžia abstrakčias, nematomas ir neregimas aplinkos ypatybes, išryškina natūralią šviesą, dangų, žemę ir orą. Tokiu būdu minimalistinio objekto kūrybos procesas yra atviras dialogui su aplinka, leidžia apspręsti pagrindines medžiagas, sukurti ryšius tarp pastato ir aplinkos (Rossel 2005).

Minimalistineje architektūroje visi dizaino elementai perteikia paprastumo idèją. Pirminès geometrinès formos, elementai be dekoratyvumo, paprastos medžiagos ir struktūriniai pasikartojimai, natūralios šviesos sklaida interjeruose sukuria solidžias, vienalytes erdves. Minimalizmo architektūra linkusi įsiklausyti i formą, ieškoti esmès, paprastumo, nematomu kokybinių parametrų paprastoje medžiagoje (Bertoni 2002).

Galima išvardinti daugybę architektūrinių objektų ikvejptų paprastumo idejjos. Tadao Ando, Antoine Predock, John Pawson, Alberto Campo Baeza priskiriami minimalizmo architektūros atstovams. Alberto Campo Baeza architektūrai būdingas paprastumas, griežtos geometrinès formos. John Pawson ir Eduardo Souto de Moura naudojo vandeni kaip pagrindini minimalumą pabrěžiantị objektą. Naudodami tradicines medžiagas ir tradicines statybos technologijas paprastą architektūrą projektuoja Peter Zumthor ir Herzog su de Meuron (Lupeikis 2007).

Andalūzijos muziejaus projekte tūrinè komplekso išraiška padiktuota konteksto (archit. Alberto Campo Baeza, 2009 m.) (208 pav.). Vertikalus 
gelžbetoninis tūris tiek erdvine konfigūracija, tiek medžiagiškumu atkartoja priešais esantį administracinį banko pastatą, projektuotą to paties Alberto Campo Baeza, suformuojant tarsi „vartus i miestą“. Ovalo formos vidinis kiemas jungia tris požeminius aukštus rampomis, o tuo pačiu ir seną bei naują korpusus, pastarasis jau vadinamas Ispanijos triumfo arka. Stengiantis pabrèžti kontekstualumo svarbą šiame objekte, vertikalioji komplekso dalis naudojama kaip infoblokas, ant kurio rodomos vaizdo projekcijos, skelbiama lankytojams svarbi informacija, pastatas yra įtraukiamas ị nenutrūkstantị miesto judesio srautą (Slessor 2009).

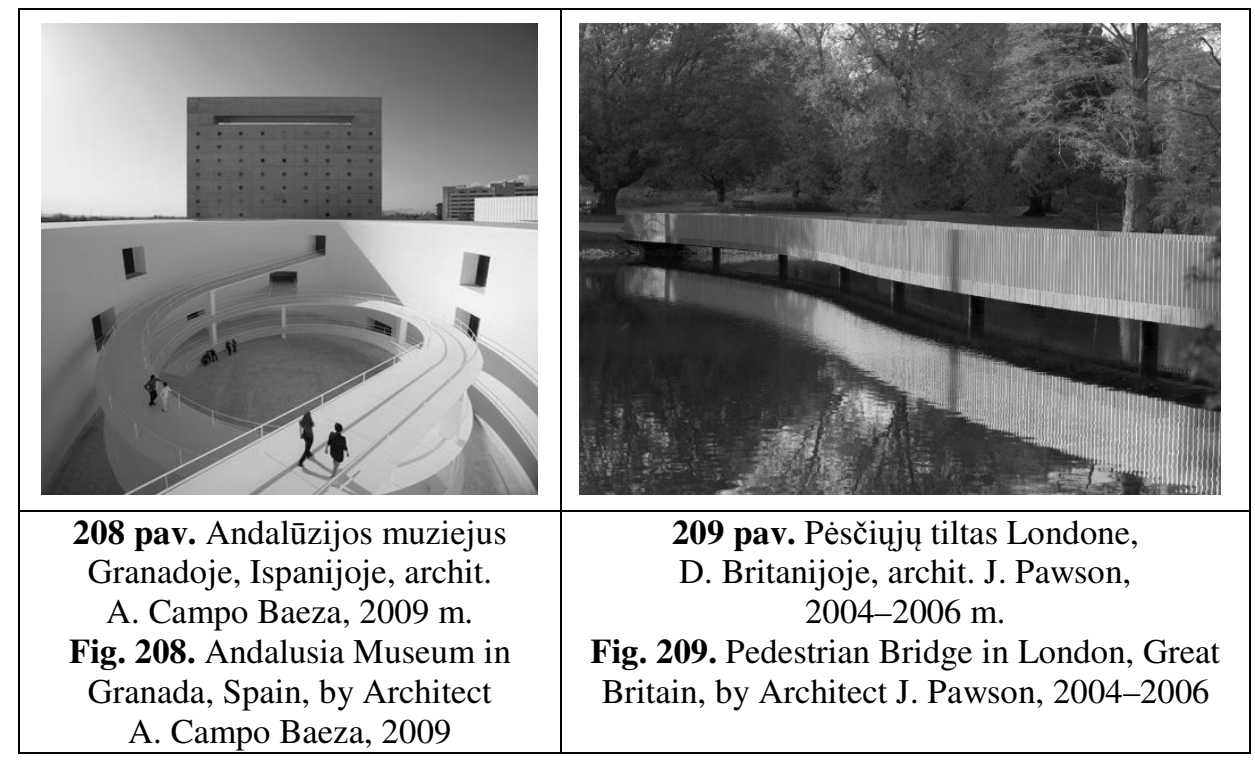

Karališkajame botanikos sode Londone, D. Britanijoje, suprojektuotas pèsčiuju tiltas (archit. J. Pawson, 2004-2006 m.) (209 pav.) atkreipia demesi i minimalistini lenktos formos santyki su vandeniu, kaip papildomu elementu, praturtinančiu meninę objekto raišką. Lenkta tilto konstrukcija sklendžia virš vandens paviršiaus, atkartojanti lenktų botanikos sodo takelių konfigūraciją. Tilto apdailai naudojamos dviejų rūšių medžiagos - granito plokštes ir bronzinio lydinio ažūriniai turèklai, atsispindintys vandens paviršiuje.

Minimalistinei architektūrai būdingas dèmesys medžiagiškumui matomas P. Zumthor suprojektuotoje Brolio Klauso koplyčioje Vachendorfe, Vokietijoje (2007 m.) (210 pav.) ir Herzog ir de Meuron projektuotame meno centre Madride, Ispanijoje (2008 m.) (211 pav.). Brolio Klauso koplyčioje panaudotas netradicinis konstruktyvinis sprendimas. Iš 112 vienodo skersmens medžio kamienų pastatytas vigvamas buvo pamažu aplipdomas 24 betono sluoksniais. Betonui sukietėjus medis buvo tiesiog išdegintas, tai paliko neịprastą sienų faktūrą interjere. Meno centro Madride rūdinto metalo apdaila žymi naujai projektuojamo 
anstato kontūrą, tačiau tuo pat metu jos grubi faktūra sukuria kompozicinę atsvarą greta esančiai ,gyvai“ augalų sienai, projektuotai Patric Blanc. Perforuotos metalinès plokštelès išlaiko naujojo antstato kontūrą, tačiau prasiskverbianti šviesa ,palengvina“ tūrị, suteikia jam lengvumo.

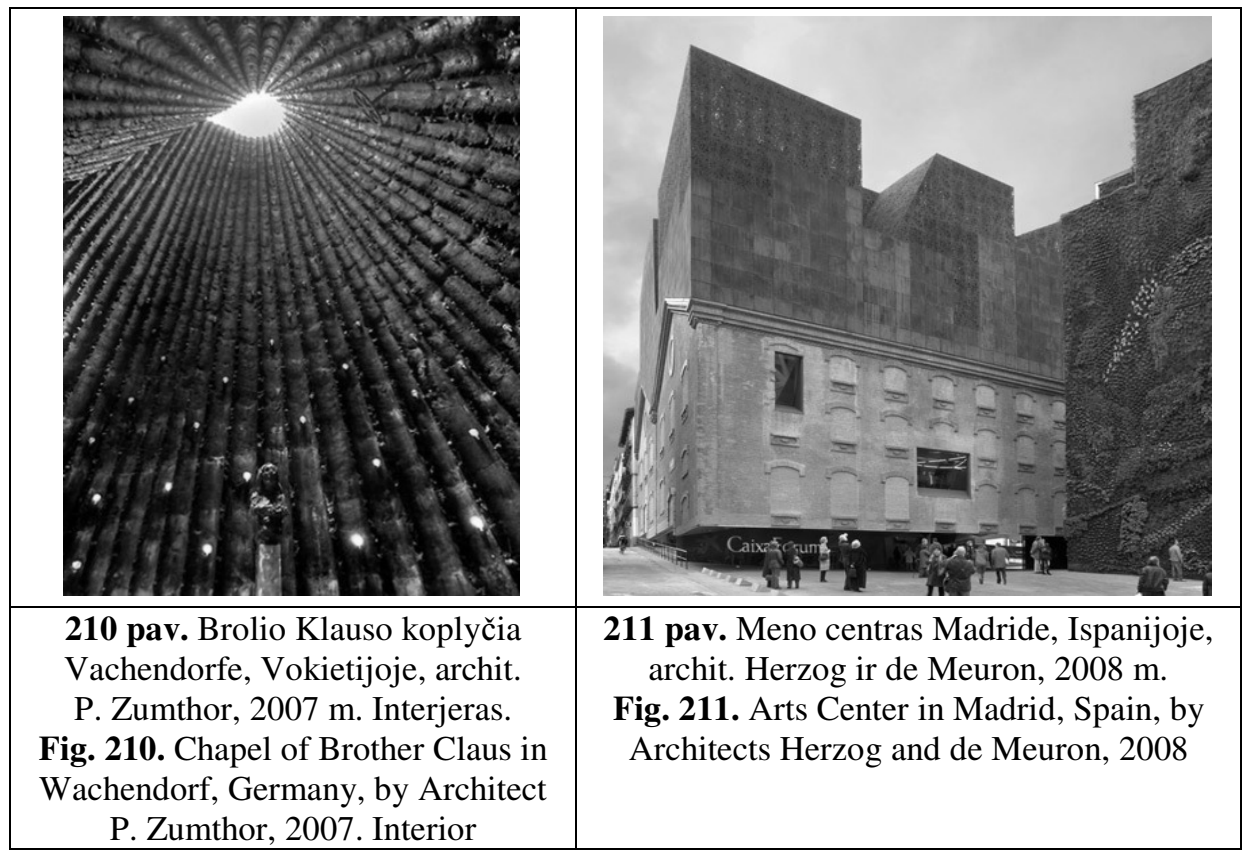

Minimalistineje Lietuvos architektūroje nèra didelès meninès raiškos ìvairovès. Dažniausia vyrauja pirminès formos ir griežti, geometriniai tūriai. Minimalistinė išraiška dažnai yra padiktuota utilitarios funkcijos, kitaip sakant, kaip už mažesnę kainą gauti daugiau ploto. Kaip pastebi K. Lupeikis, dauguma Lietuvos architektų įsivaizduoja, jog minimalizmas yra tik kubas ar stačiakampis gretasienis (suprantama, šios formos yra minimalios), tačiau dažnai pamiršta, jog kitos pirminès formos, tarkime sfera, cilindras, kūgis ar kitos plastiškos formos taip pat yra minimalios. $\mathrm{O}$ ir meninès raiškos asketiškumas kilo ne iš dvasinių ar filosofinių priežasčių, o iš pragmatiškų ir utilitarių tikslų. Dėl šių priežasčių lietuviškas minimalizmas turèjo daugiau funkcionalizmo, purizmo, brutualizmo bruožų (Lupeikis 2002). Tiesa ir patys architektai kažin ar vadovavosi minimalistiniais kūrybos principais. Tai iškelia klausimą, ar paprastą bei funkcionalią, estetiškai, tūriškai ir funkciškai utilitarią formą galime laikyti minimalizmu. Galbūt tai reikètų vadinti tiesiog minimaliomis raiškos priemonėmis, arba tiesiog minimalistine raiška. Šiuolaikinès Lietuvos architektūros tyrimuose pasitaiko siekių klasifikuoti minimalizmą i tam tikras kategorijas (Minkevičius 2012), tačiau su tuo sutikti būtų sudètinga, kadangi pats 
minimalizmas yra idejjinè architektūros kryptis, ir pagal raiškos bruožus ją kategorizuoti nèra tikslinga.

\begin{tabular}{|c|c|}
\hline 212 pav. Gyvanamasis & 213 pav. Gyvanamasis namas Alytuje, archit. \\
namas Kaune, archit. G. & G. Natkevičius, R. Adomaitis, 2002 m. \\
Natkevičius, R. Adomaitis, & Fig. 213. Dwelling house in Alytus, by Architects \\
2001 m. & G. Natkevičius and R. Adomaitis, 2002 \\
Fig. 212. Dwelling house \\
in Kaunas, by Architects \\
$\begin{array}{c}\text { G. Natkevičius and } \\
\text { R. Adomaitis, 2001 }\end{array}$ \\
\hline
\end{tabular}

Kaip vienas minimalistinès raiškos pavyzdžių galètų būti prekybos centras „Akropolis“ (archit. G. Jurevičius 2002 m.). Pirminès - stačiakampio gretasienio formos tūris aprengtas ịvairiomis medžiagomis. Stiklo medinių dailylenčių, rūdintos skardos intarpai panaudojami monumentaliam tūriui skaidyti. Atviros metalo konstrukcijos iejjimo stogelis taip pat visiškai priešingas minimalistinei estetikai. Žaidimu medžiagomis, spalvomis ir faktūromis siekiama sukurti daugiasluoksniškos, turtingos savo išraiška architektūros ispūdị. Tačiau tenka pripažinti, kad liekama prie imitacijos. Panašių pavyzdžių galima aptikti ir daugelyje panašių objektų, tai ypatingai pastebima prekybos pavilijonuose, kur architektūrinè raiška turi būti reprezentatyvi ir turtinga, tačiau funkciškai - tai tėra angaras su dideliais tarpatramiais, siekiant išlaikyti prekybinių erdvių transformacijos galimybes. Pasaulineje architektūroje seniai pastebimos tokios paskirties architektūrinès tendencijos. Dažnai jos atspindi masinị, vartotojišką skonį, pereinantị i kičą. Kaip teigia K. Lupeikis: „Minimalistinès tendencijos prekybos centrų architektūroje Lietuvoje apskritai yra savitas reiškinys, matyt susiformavęs vietinių tradicijų terpeje. Tuo tarpu minimalistinè raiška pasaulinèje architektūroje daugiau siejama su elitinès mados, kultūrinès, sakralinès, gyvenamosios paskirties objektais“(Lupeikis 2002).

Gyvenamosios paskirties objektuose Lietuvos architektūroje, minimalizmo tendencijas galima aiškiai pastebèti architekto G. Natkevičiaus projektuose. Gyvenamojo namo Kaune (kartu su R. Adomaičiu 2001 m.) (212 pav.) projekte minimaliai formai perteikti naudojamas arkos motyvas. Trijų gyvenamujų namų 
projekte Alytuje (kartu su R. Adomaičiu 2002 m.) (213 pav.) minimalistinè raiška pažymima trimis monumentaliais griežtų formų tūriais, vienodu ritmu išdèstytais palei gatvę. Šiuo atveju monumentalumas pabrèžiamas simetriška fasadų raiška, stikliniu erkeriu, pabrěžiančiu fasado centrą. Minimalistinè estetika matoma ir gyvenamojo namo Kaune (kartu su T. Kuleša ir L. Kraniausku 2009 m.) (214 pav.) eksterjere ir interjeruose. Jautri intervencija ị esamą užstatymą sudètingoje urbanistineje aplinkoje, naudojant minimalistines priemones, matoma gyvenamojo namo rekonstrukcijoje ir išplètime Vilniaus Žvėryno rajone (kartu su R. Adomaičiu, R. Babrausku 2006 m.) (215 pav.).

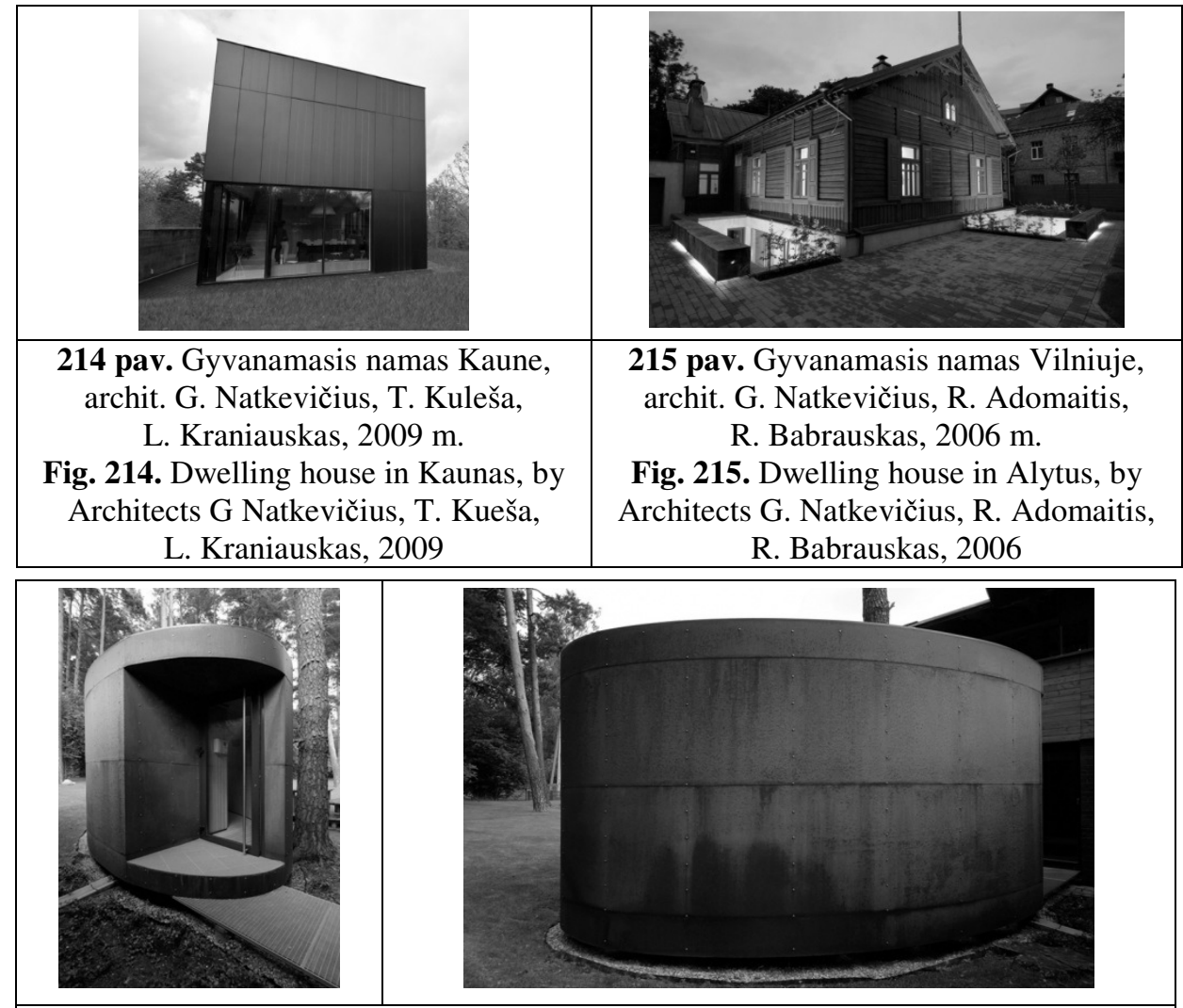

216 pav. Pirtis Vilniuje, archit. G. Natkevičius, T. Kuleša, E. Spūdys, 2006 m. Fig. 216. Sauna in Vilnius, by Architects G. Natkevičius, T. Kuleša, E. Spūdys, 2006

Išskirtinis minimalistinès estetikos pavyzdys, taip pat projektuotas architekto G. Natkevičiaus yra pirties projektas Vilniuje (kartu su E. Spūdžiu, T. Kuleša 2006 m.) (216 pav.). Pirminès geometrinès formos tūris tarsi simbolizuoja vienintelę pastato paskirtį, tuo pačiu atskiria nuo greta esančio gyvenamojo namo. Rūdinto metalo apdaila suteikia pastatui monumentalumo ispūdị. Panašus minimalistinis sprendimas igyvendintas laikiname kavinès pavilijone Kaune 
(archit. D. Čiuta, R. Vieštautas, 2000 m.). Pirminių geometrinių formų raiška minimalistineje architektūroje pastebima administraciniame prokuratūrų pastate Vilniuje (archit. K. Lupeikis 2008 m.) (218 pav.), M. K. Čiurlionio galerijos pastate Kaune (archit. G. Janulytė -Bernotienė $2002 \mathrm{~m}$.), taip pat gèlių salono pastate Prienuose (archit. K. Indriūnas, D. Gasiūnienè 2004 m.), ir kt.
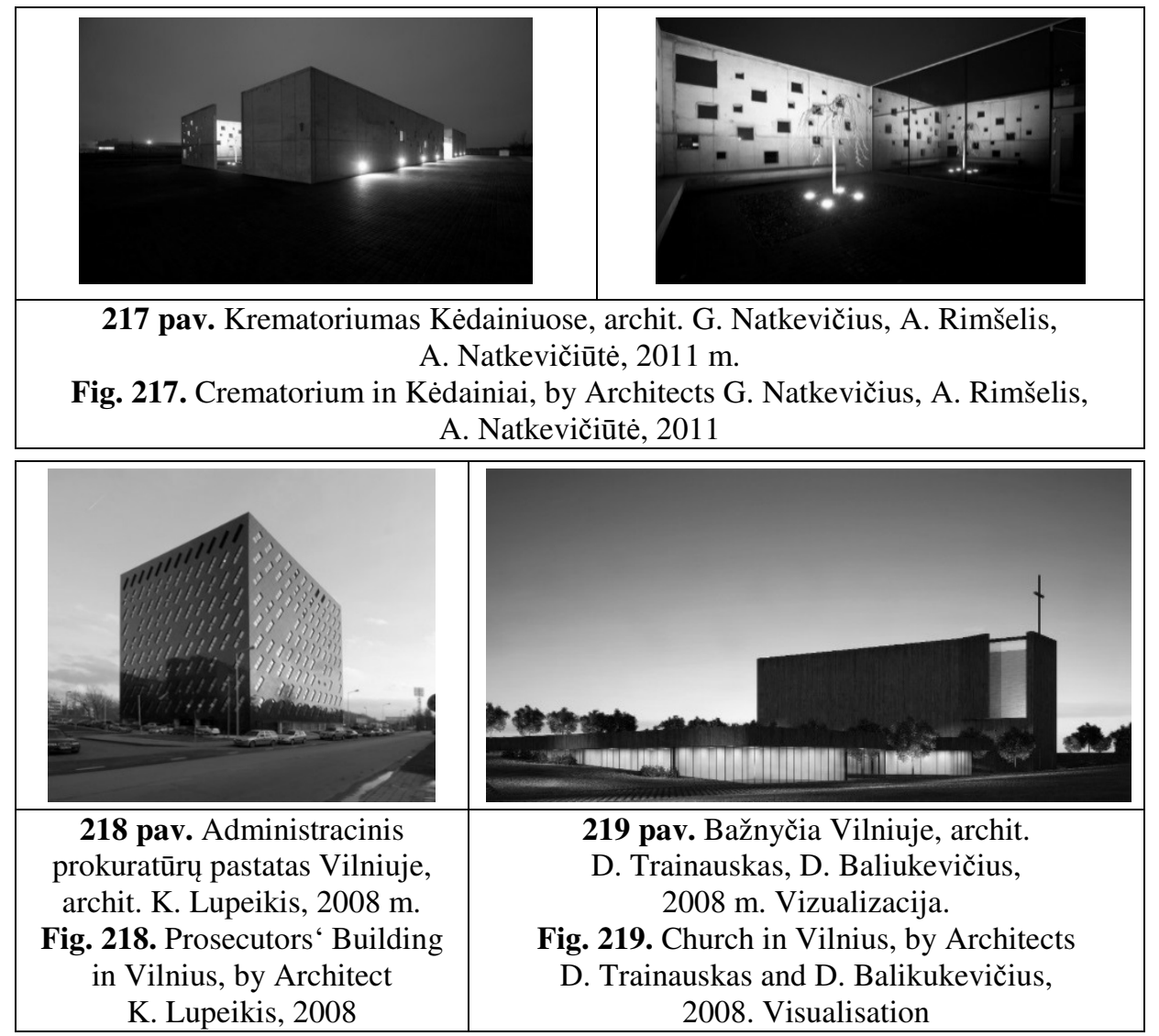

Sakralinès paskirties objektų architektūroje, minimalistinè raiška pastebima Kèdainių kolumbariumo projekte (archit. G. Natkevičius A. Rimšelis, A. Natkevičiūtė 2011 m.) (217 pav.). Japonų minimalistų inspiruota betono ir stiklo estetika šiame objekte sukuria rimties ir susikaupimo nuotaiką. Pastato forma padiktuota aplinkinio užstatymo charakteristikų (pramoninė zona), todèl nuo pat pradžiu buvo siekiama sukurti uždarą pastatą, suteikianti privatumo jausmą. Betono estetika monumentaliam tūriui pabrèžti naudojama ir Pašilaičių bažnyčios projektiniuose pasiūlymuose (nerealizuotas) (archit. D. Trainauskas, D. Baliukevičius 2008 m.) (219 pav.). 
Dekonstruktyvistinès ir minimalistinès tendencijos šiuolaikinès architektūrinès formos kūrimo procesuose. 1994 metais architektūros tyrinètojas ir tuometinis žinomo periodinio architektūros teorijos leidinio $\mathrm{AD}^{16}$ vyriausias redaktorius Greg Lynn, visą numerị skyrè naujam architektūrinès formos deformavimo pobūdžiui - lenkimui. Šis konkretus leidinys svarbus tuo, jog pakreipè architektūros teorijos tyrimus link nestatmenos geometrijos ir biomorfinių formų. G. Lynn, nagrinèdamas BLOB formas ${ }^{17}$ susidomèjo lenkimais, klostemis, raukšlèmis, ir kitais lanksčiais paviršių ir formų transformavimo būdais skaitmenineje ir neskaitmeninejje erdveje. Šiame leidinyje aptariami formų tyrimai kildinami iš šiame skyriuje aptariamų dekonstruktyvizmo ir minimalizmo tendencijų. Būtent pirminių ir minimalių formų bei paviršių transformacijos leidžia pasiekti dekonstruktyvistams būdingų formų variacijas, o taip pat jas apjungti.

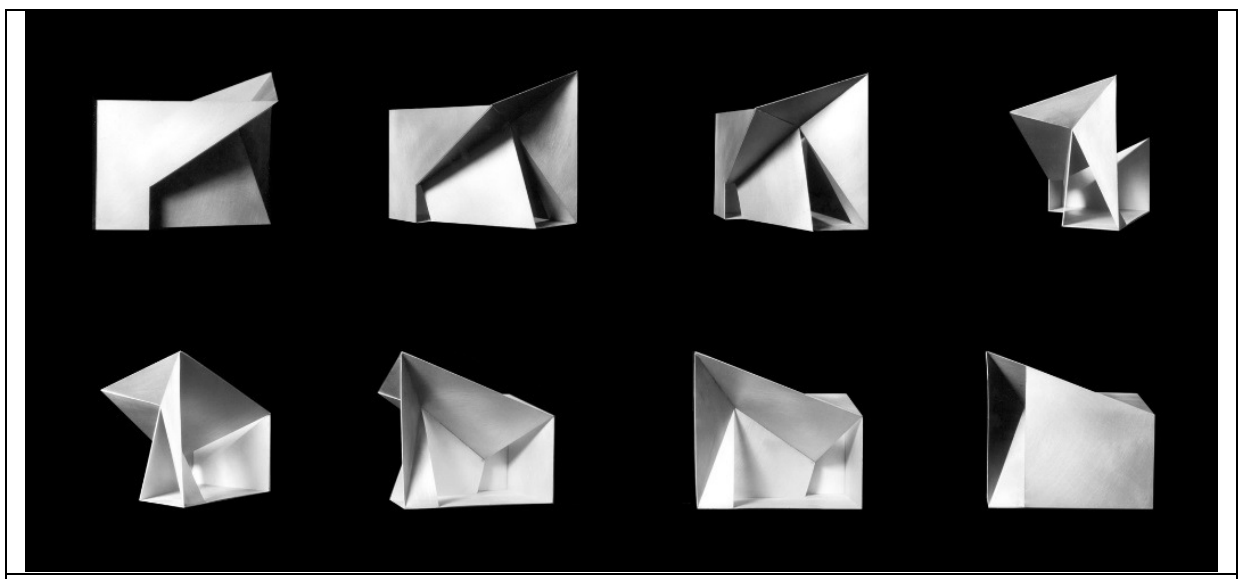

220 pav. Koplyčia Almadene, Ispanijoje, archit. S.M.A.O., 2001 m. Koncepcija.

Fig. 220. Chapel in Almadene, Spain, by Architects S.M.A.O., 2001. Concept.

Tokiu formų modeliavimo principu, bei istorinių formų interpretacija pasižymi Pašilaičių bažnyčios konkurso projektinis pasiūlymas (archit. A. Baldišiūtè, A. Neniškis, M. Jusaitè, A. Tilvikaite, L. Zwijsen, L. Rekevičius 2008 m.) (222 pav.). Autorių teigimu, ,tūrio išeities taškas - stačiakampio gretasienio pasirinkimas. Tolesnis jo modeliavimas grịstas bažnyčių architektūros istorijos interpretacija. Jị sudaro du trikampiai - šventorius ir bažnyčia. Per stiklinę sieną kiemo pusejje saule apšviečia altorių, šią vietą išskirdama ir pakylèdama. Kadangi bažnyčios salès erdvè yra trikampè, jos smailūs kampai gali tarnauti kaip improvizuotos koplyčios - vienoje gali būti įrengiama krikštykla,

${ }^{16}$ Architectural Design

17 BLOB (angl.) - didelis skaitmeninis objektas, kompiuteriniame projektavime gaunamas sujungiant ir transformuojant sferų paviršius 
kitoje relikvijorius. Bažyčios „trikampio“ kampas, kuriame orientuotas iejjimas, suaukštintas - taip formuojamas pastatas kaip lokali dominantè, bei atiduodama duoklè tradiciniams bokštams bažnyčių frontonuose" (Baldišiūtè 2007). Panašus formos modeliavimo konceptas panaudotas architektūros studijos S.M.A.O. projektuotos koplyčios Almadene, Ispanijoje (2001 m.) architektūroje (220, 221 pav.).

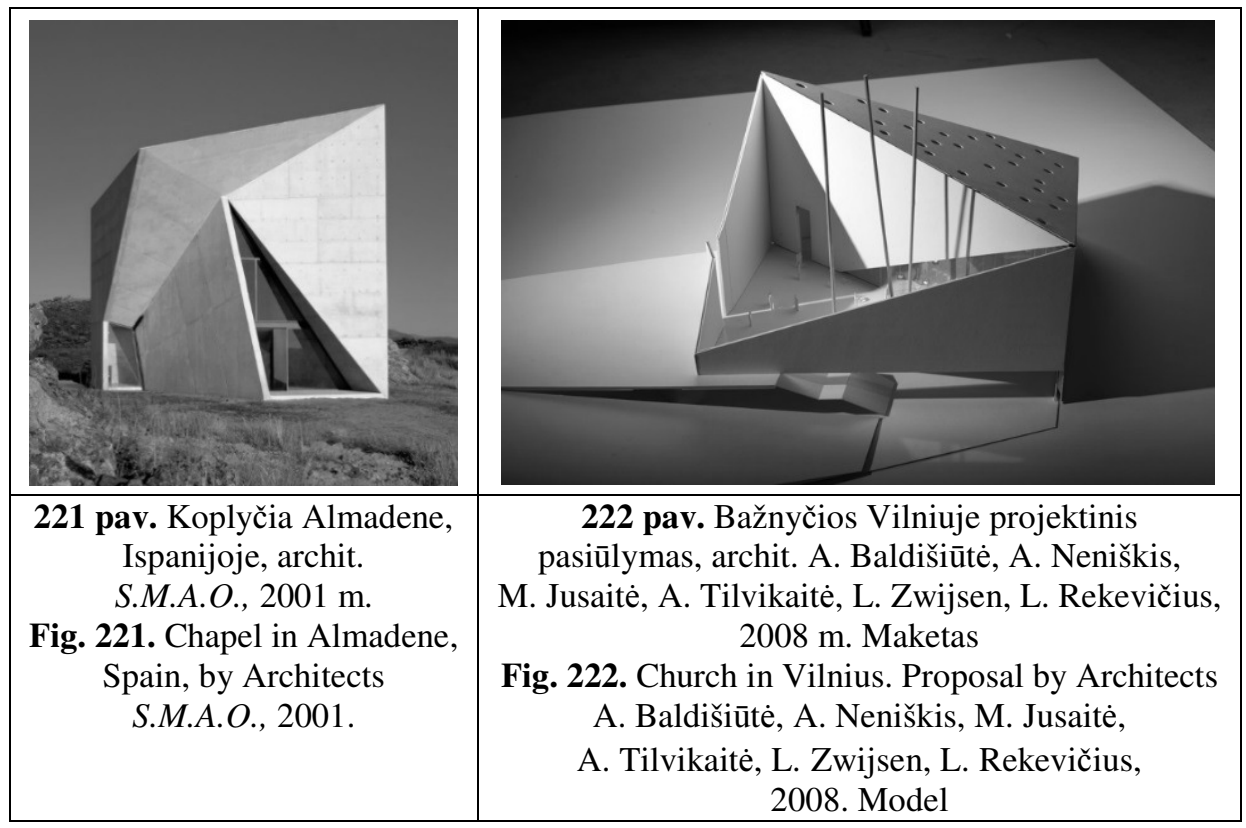

G. Lynn teigia, jog lankstumas leidžia architektūrinei formai būti monumentaliai, bet tuo pat metu ir kompleksiškai. Jungiant įvairių formų derinius gaunamos ištisos struktūros peržengiančios ribą tarp atskiro pastato ir, pavyzdžui, urbanistinio kvartalo užstatymo ar net ištiso rajono sprendimo. Tokios kompleksiškos formos (beje, G. Lynn ši terminą skolinasi iš R. Venturi postmoderniosios architektūros apibūdinimo) yra atviros bet kokiam tęstinumui, kadangi jungimai yra tiesiog suniveliuojami CAD programomis. Kompleksiška forma nèra vienalytè, tačiau taip pat nèra ir fragmentiška (Lynn 1993b). G. Lynn pažymi, jog dekonstruktyvizmas kaip architektūros kryptis, deklaravo aplinkos skirtumus ir stengèsi juos iliustruoti architektūrinès formos pagalba, tačiau ši retorika švelnejja, siekiant atsižvelgti i aplinkos ir kultūrinio konteksto išskirtinumus kiekvienu konkrečiu atveju, taigi kompleksiškos formos taip pat leidžia kurti kontekstualią architektūrą (Lynn 1993b). 


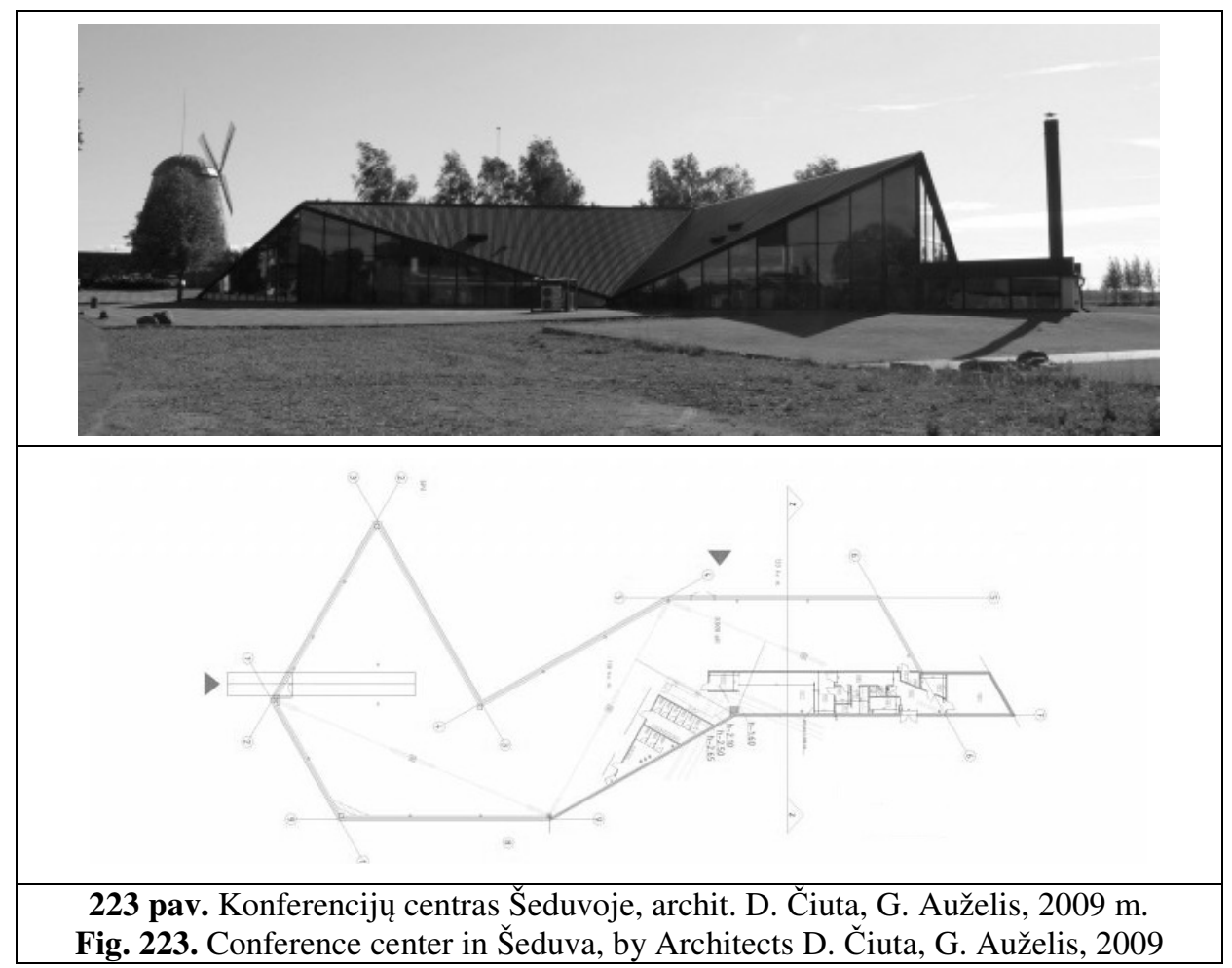

Dekonstruktyvizmo ịtaką skaitmeniniame formų kūrimo procese pastebi ir Jeffrey Kipnis, straipsnyje „Towards a New Architecture“ (1993 m.) (Kipnis 1993). J. Kipnis nurodo dvi sąlygas, reikalingas kurti „naujają architektūrą", tai nauji formos kūrimo principai (paremti nedekartiškaja ${ }^{18}$ geometrija), ir naujos formos (lenktos plokštumos). Jis taip pat teigia, jog šios, naujos kūrybos strategijos, būdamos atsakas postmodernizmui ir dekonstruktyvistiniam koliažui yra įtakotos naujų kūrybos principų, todèl negali būti vertinamos pagal jau nusistovejjusius stilistinius kanonus. Mark C. Taylor straipsnyje „Seaming“ (1993 m.) ir Bernard Cache straipsnyje „Digital Semper“ (1999 m.) akcentuoja minimalaus paviršiaus svarbą modeliuojant kompleksiškas formas. Cecil Balmond straipsnyje „New Structure and the Informal“ (1998 m.) apskritai neigia formų svarbą šiuolaikinejje architektūroje, teigdama, jog skaitmeniniai modeliavimo procesai teigia neformalumą, t. y. formos, ir net pastato, kaip autonomiškos struktūros nebūvimą. Nelinijiniai kūrybos procesai lemia intuityvų modeliavimą, nesuvaržytą struktūrinių faktorių, atsižvelgiantị ị kontekstą, socialinius procesus, taip, autorès teigimu, gaunamas geriausias rezultatas, gebantis reaguoti $\mathfrak{i}$ visus išorès faktorius.

18 angl. Non-Cartesian 
Kontekstualios ir atviros transformacijoms formos pavyzdžiu Lietuvos architektūroje galètų būti Dariaus Čiutos ir Gintaro Auželio suprojektuotas laisvalaikio ir konferencijų centras Šeduvoje (2009 m.) (223 pav.), pačių autorių vadinamas „Origami namu“ (Grunskis 2012). Pastato formomis siekta išryškinti Šeduvos malūną kaip unikalų kultūros paveldo objektą ir įsilieti ị esamą aplinką. Lenkta pastato forma pasirinkta ne atsitiktinai. Kadangi vieta yra gana vejjuota, pastatas suteikia tam tikrą užuovèją. Pastato stogų forma gali būti vertinama kaip senojo kaimo architektūros interpretacija, tuo siekiama prisitaikyti prie aplinkinių pastatų charakterio.

Nuolaidžios $\mathrm{V}$ formos plokštumos yra atkartojamos tokios pačios formos atramomis vidinèse erdvèse. Interjero erdvè susilieja su eksterjero formomis ir tuo pačiu su aplinkiniu kontekstu. Pagrindinès medžiagos, naudojamos pastato statyboje, yra medis, stiklas ir metalas. Pastato erdvé yra lengvai transformuojama, atsižvelgiant i pasikeitusius poreikius, jos funkcijos taip pat kintančios.

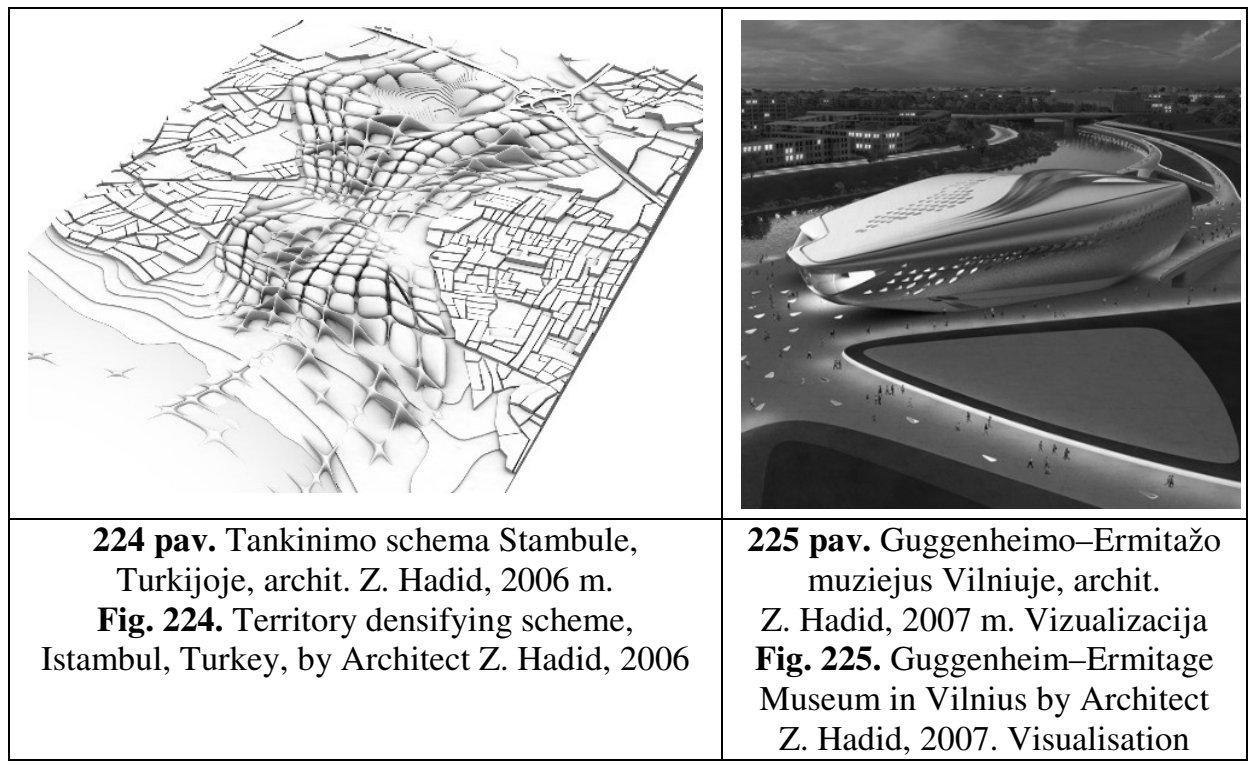

2008 metais, 11-ojoje Venecijos architektūros bienaleje buvo pristatytas naujos, paremtos kompiuterinemis technologijomis architektūros krypties parametricizmo manifestas (Kučinskas 2009), kuris neigia iprastines formu tipologijas, platoniškos geometrijos objektus, pasikartojimus, tiesias linijas, tikslius kampus, skatina ịvairaus pobūdžio tūrių deformacijas (Schumacher 2008). Parametrinis projektavimas, kaip atskiras formos modeliavimo konceptas, pradètas naudoti urbanistinèms sistemoms kurti, pavyzdžiui Z. Hadid pasiūlytuose „One North“ mokslo inkubatoriaus Singapūre (2001-2021 m.), arba 
Stambulo rajonų tankinimo (2006 m.) (224 pav.) urbanistiniuose sprendimuose. Šių urbanistinių struktūrų principas paremtas elastingo tinklo modeliu, kuris lankstomas atsižvelgiant ị esamą urbanistię situaciją ir aplinkinius faktorius, tokius kaip topografiniai pokyčiai, insoliacija, atsiveriančios panoramos ir pan. Tokio planavimo pagrindinis privalumas - galimybe koreguoti ji, keičiantis poreikiams, taip pat formuoti tęstinumą (Schumacher 2011). Panašūs estetiniai sprendimai igyvendinti Guggenheimo-Ermitažo projektiniuose pasiūlymuose, Vilniuje (2007 m.), kur pačioje pastato struktūroje užkoduotas judesys, nebaigtumas, tai matoma ir iš pastato komponavimo reljefe, kur sudaromas ìspūdis, tarsi muziejaus tūris būtų viena dalis didelèje sistemoje (225 pav.).

\subsection{Antrojo skyriaus apibendrinimai}

1. Vèlyvojo modernizmo techninè estetika atspindèjo svarbų etapą Lietuvos architektūroje. Galimybès rinktis iki tol nenaudotas medžiagas sąlygojo high-tech architektūros proveržị. Atvirai eksponuojamos konstrukcijos buvo naudojamos tiek interjeruose, tiek eksterjero detalèse. Utilitari high-tech meninè raiška tapo populiari autosalonų architektūroje (ypatingai didelis šios paskirties kompleksų proveržis pastebimas paskutiniojo XX a. dešimtmečio pabaigoje), taip pat prekybos centrų interjeruose. Pavienès high-tech detalès (atvirų konstrukcijų iejjimo stogeliai, rampos, turèklai ir kt.) naudojamos ir kitų architektūros krypčių pastatuose. Slick-tech architektūra Lietuvoje, siejama su dešiniojo Neries kranto urbanizacija Vilniuje. Iki tol verslo korporcijoms būdinga blizgių paviršių meninè raiška buvo naudojama epizodiškai. Slick-tech architektūrai būdingas asketiškas geometriškumas prisidejo prie minimalistinès raiškos savitumo Lietuvos architektūroje, o autonomiškas paviršiaus traktavimas sukūrè prielaidas ìvairesniems architektūrinès formos kūrimo procesams.

2. Postmodernistinè estetika Lietuvos architektūroje atspindi chaotišką ir sudètingą paskutiniojo XX a. dešimtmečio politinę ir socialinę situaciją. Privatus užsakovas, iki tol nenaudotos medžiagos, galimybè kurti ir realizuoti ịvairiausio pobūdžio objektus sąlygojo stilistinị chaosą, iliustruotą postmodernistine eklektika. Pavieniai postmodernistinès architektūros elementai, aplikacijos būdu taikomi vẻlyvojo modernizmo kontekste, kūrè vizualią postmodernistinę imitaciją. Šiuo laikotarpiu aktyviai taikoma istorinių formų stilizacija, vietomis perauganti i eklektiškumą, pastebima ženkli konteksto ịtaka architektūrinei formai. Konvertuojamos senamiesčiu erdvès pasižymi pagarba istoriniam užstatymui, ịvairaus pobūdžio interpretacijomis.

3. Skaitmeniniams architektūrinès formos kūrimo procesams igaunant vis didesnę svarbą šiuolaikinejje architektūroje, išskiriamos dekonstruktyvizmo ir minimalizmo tendencijos. Dekonstruktyvistiniai formos modeliavimo konceptai 
suteikia minimalistinei raiškai tęstinumo ir neužbaigtumo savybes, tuo pačiu išsaugodami monumentalias jos savybes. Lietuvos architektūroje atviros formos kūrimo principai vis dar yra naujiena, tačiau iš pavienių objektų, o taip pat iš susidomejjimo autonominių paviršių raiška, galima daryti prielaidą, jog šios architektūros kryptys turi tendencijų plètotis. 



\section{Šiuolaikinès Lietuvos architektūros stilių ir krypčių modelis}

Originalumo faktorius šiame tyrime suvokiamas kaip naujos perspektyvos pateikimas ir kaip naujas požiūris ị egzistuojančią medžiagą. Apibendrinant ankstesnèse dalyse atliktą architektūros stilių ir krypčių analizę, siekiama pateikti inovatyvų požiūri i šiuolaikinius architektūrinès formos kūrimo procesus, nurodyti tai įtakojusias tendencijas, sukuriant pagrindą naujiems tyrimams šiuolaikinès architektūros meninès raiškos srityje. Kuriamame modelyje vengiama kategorizuoti procesus $i$ perspektyvius ir neperspektyvius, nèra atliekama vykstančiu procesų kokybinè analizè. Šiuo modeliu siekiama išanalizuoti, apibrežti ir paaiškinti kontekstą, kuriame vystėsi šiuolaikinè Lietuvos architektūra.

\subsection{Modelio kūrimo teorinès prielaidos ir pagristumas}

Stilius arba stilistinis laikotarpis yra svarbus menų raidą apibūdinantis teorinis apibrèžimas, teorinè struktūra. Stilių apibrèžimai yra naudojami kaip teorinès ribos įvairių meninių objektų tyrimams. Kiekvienos žmonių kartos 
menininkai, dizaineriai ar architektai kūrè kitokị stilių. Kiekviena karta turi savo pageidavimus dèl meninio objekto išvaizdos, taip pat ir dèl praktinių savybių. Stiliai neatsiranda netikètai, iš tuščios erdvès, taip pat jie nešnyksta ị nebūtị. Stilių evoliucijos etapai yra panašūs i gyvo organizmo - augimas, branda, išnykimas. Stilių raidos seka ir jų tarpusavio ryšiai gali būti apibūdinami vizualiai, kuriant grafinius modelius. Reikšmingiausius architektūros stilių ir krypčių tyrimus meninès raiškos požiūriu yra atlikęs Ch. Jencks, daugumoje monografijų pateikdamas su nagrinėjamu laikotarpiu susijusius modelius. Jų ryšys su šiame tyrime kuriamu stilių ir krypčių modeliu aptariamas skyriuje 3.3.

Kuriant architektūros stilių ir krypčių modelį, šiame darbe remiamasi Helsinkio menu ir dizaino universiteto (University of Arts and Design Helsinki (UIAH)) profesoriaus Pentti Routio aprašytu Normatyviniu raidos tyrimu (angl. Normative study of development) (Routio 2007). Šis tyrimas pritaikomas remiantis anksčiau sukurtų Ch. Jencks stilių ir krypčių modelių principais (Evolutionary Tree of Late-Modern Architecture, Evolutionary Tree of PostModern Architecture) (Jencks 1982), juos papildant ir pritaikant Lietuvos architektūros raidai.

\section{Normatyvinis raidos tyrimas}

Šis tyrimo metodas yra pagrịstas istorijos moksle plačiai naudojamu raidos tyrimu, kuris objektyviai aprašo tam tikrų ịvykių seką. Tokiame tyrime veikia nekintantys parametrai (pavyzdžiui ilgis metrais, laikas metais ir pan.), kurie apibrèžia tiriamojo objekto ar objektų vietą sudarytoje klasifikacijoje. Jeigu tam tikrus parametrus reikia papildomai apibrěžti, toks raidos tyrimas yra vadinamas normatyviniu. Daugelis tradicinių menotyrinių darbų turi paslèptą normatyvinę esmę net ir tada, kai autorius bando pristatyti savo darbą kaip „objektyvų aprašymą" naudojant raidos tyrimo metodus. Normatyvinis raidos tyrimas taip pat yra objektyvus, tačiau jame naudojami normatyviniai parametrai turi būti papildomai išaiškinti, nurodytas jų naudojimo priežastingumas (Routio 2007). Šiame tyrime normatyvinis parametras yra stiliai ir kryptys, kurių klasifikacija pateikiama I ir II dalyse, remiantis Lietuvos ir užsienio architektūros tyrinètojų darbais. Šis stiliu ir krypčiu modelis vertina kokybinius kiekvieno stiliaus ar krypties meninès raiškos faktorius. Nustatant kokybinius nagrinejjamo objekto parametrus nagrinejjami giluminiai reiškinių procesai, jų struktūra, paplitimo būdai. Remiantis gautais rezultatais, galima atlikti kiekybinius stiliaus ar krypties meninès raiškos tyrimus, nagrinejjant kiekvieną stilių ar kryptį individualiai (Savin, et. al. 2013). 


\section{Medžiaga ir jos klasifikavimas normatyviniame tyrime}

Priešingame normatyviniui - aprašomajame raidos tyrime dažniausiai siekiama išsiaiškinti, kaip viskas vyksta (arba kaip vyko). Normatyvinių tyrimų tikslas yra nustatyti, kaip viskas turètų būti. Toks tyrimo procesas yra naudojamas daugelyje moksliniu tyrimu numatant plètros perspektyvas. Tyrimo metu išryškèja tam tikras etapiškumas: informacijos rinkimas, apibendrinimas, sisteminių panašumų ar skirtumų fiksavimas, naujų normų nustatymas. Objektai, nagrinėjami normatyviniame tyrime dažniausiai atrenkami selektyviai, ne bandant pakreipti rezultatą norima linkme, o siekiant supaprastinti tyrimą, paliekant tik tuos objektus, kurie turi tiesioginę įtaką tyrimo tikslui. Šiuo konkrečiu atveju nagrinejjami tik tie objektai, kurie žymi vieną ar kitą architektūros kryptị, turinčią tiesioginès įtakos šiuolaikinès Lietuvos architektūros meninei raiškai.

Sistemingas klasifikavimas yra ypač svarbus normatyviniame tyrime, nuo to priklauso galutinis rezultatas. Medžiagos (šiuo atveju architektūrinių objektų) skirstymas i grupes šiame tyrime yra tiesiogine jo išdava. Klasifikavimo tikslas visuomet yra tas pats - atskleisti sistemingą reiškinio ar objekto struktūrą. Problema yra ta, jog ne visi objektai ar reiškiniai atitinka vienos ar kitos klasès apibrěžimą, o dažnai gali pasižymèti savybėmis, būdingomis kelioms klasėms. Tokiu atveju normatyviniuose tyrimuose naudojama speciali klasė neklasifikuojamiems objektams, tačiau turint omenyje tai, jog šis konkretus tyrimas nèra kiekybinis, o kokybinis, neklasifikuojami objektai tyrime nebus nagrinejjami, o objektai patenkantys ị kelias klases, jose ir bus vaizduojami.

Normatyviniuose tyrimuose objektu atitikimas vienos ar kitos klasès apibrěžimui dažnai kvestionuojamas, kadangi dažniausiai tiriamas objektas pasižymi ne visomis konkrečiai klasei būdingomis savybèmis. Vis dèlto, normatyviniuose tyrimuose yra priimta klasifikuoti objektus, kuriuose matoma dauguma konkrečiai klasei būdingų bruožų. Tokia klasifikacija vadinama apytiksle (Routio 2007), tačiau turi ir tipologinès klasifikacijos bruožų. Tipologinejje klasifikacijoje visi objektai skirstomi remiantis vienu konkrečiu pavyzdžiu, teigiant, jog toks egzempliorius pasižymi visais klasès bruožais. Turint omenyje, jog šiame tyrime remiamasi konkrečiais pavyzdžiais, tipologizavimo nèra įmanoma išvengti.

Stiliu klasifikacija visuomet bus apytiksle ir dažnai subjektyvi. Stiliaus kriterijai paprastai yra apibrěžiami kaip kvalifikacijų rinkinys, kuris turi būti išpildytas nuosekliai ir tuo pačiu metu, ir be viso to, dažnai vienetiniame meno objekte. Stiliaus klasifikacija dažniausiai naudojama apibrěžti ir išskirti objektus, sukurtus tuo pačiu laikmečiu. Stiliai dažnai naudojami ne klasifikuoti objektų meninę raišką, o apibrèžti istorinę seką. 


\section{Priklausomi ir nepriklausomi modelio kintamieji}

Nepriklausomi kintamieji - apibendrinti anksčiau, arba objektyviai nustatomi pagal tyrinejjamo objekto struktūrą, formą, meninę idèją, vertybinius prioritetus.. Analizuojant reiškini, objektą, ir pan., menotyriniu aspektu, laiko dimensija gali būti svarbi, arba ne. Kadangi architektūros stilių ir krypčių kaita pastebima laike, ir tai yra vienas svarbesnių laikotarpio ar epochos bruožų, sudarinejjamame modelyje laiko dimensijos išraiška bus vienas iš nepriklausomų kintamujų, kurio dèka modelis tampa dinamišku ir kintančiu. Kadangi klasifikavimo tikslas yra surasti sisteminę tam tikrų reiškinių ar ivvykių struktūrą, bendrą visiems aptariamiems atvejams būdingą nekintantị bruožą, todèl architektūros stiliai, kryptys ir meninès raiškos bruožai taip pat yra nepriklausomi kintamieji nurodantys konkrečias sugrupuotų objektų savybes. Stilių ir krypčių klasifikavimo priežastingumas tiriamas dedukciniu metodu ir pagrindžiamas I ir II dalyse.

Nepriklausomi kintamieji išdèstomi koordinačių ašių principu - vertikaliai ir horizontaliai.

Priklausomi kintamieji - apibūdina pokyčius ir judejimą. Priklauso nuo nepriklausomujų kintamujų, tyrime desstomi jų atžvilgiu. Šiame tyrime priklausomi kintamieji yra konkrečius stilistinius laikotarpius atspindintys architektūriniai objektai.

Stilių ir krypčių klasifikacija paremta meninemis idejomis visuomet skirsis nuo klasifikacijos paremtos materialiais kintamaisiais, pavyzdžiui medžiagiškumu (medinis, betoninis, stiklinis ir t.t.), konstruktyviniais sprendimais (karkasinis, mūrinis ir t.t.). Meninèmis idejomis paremtoje stilistinejje klasifikacijoje visuomet liks neapibrěžtų objektų, nepatenkančių i nei vieną klasifikuojamą grupę, arba dèl išskirtinès architektūrinès raiškos patenkančių i kelias.

Pastovūs modelio dydžiai (dimensijos):

- horizontali ašis - laikas;

- vertikali ašis - meninès raiškos bruožai.

Nepastovūs modelio dydžiai:

- $\quad$ architektūriniai objektai.

\section{Grafinè modelio išraiška}

Grafinè modelio išraiška remiasi linijinès laiko juostos principu ( $\mathrm{X}$ ašyje), ivedant papildomas normines dimensijas ( $\mathrm{Y}$ ašyje). Toks grafinis reiškinių ar ịvykių vaizdavimo būdas vadinamas laiko linija ${ }^{19}$, ir yra dažnai naudojamas iliustruoti chronologinę ivvykių seką, pateikiant tyrimo išvadas. Nagrinejjami

${ }^{19}$ angl. Timeline 
ịvykiai ar procesai tuomet išdėstomi dviejų ašių koordinačių plokštumoje. Grafinè laiko linijos išraiška plačiai naudojama edukacijoje, padedant studentams ar tyrejjams lengviau suvokti procesų sekas, tuo pačiu suteikiant galimybę ịvertinti greta vykstančius procesus, apibūdinti atskirų reiškinių ar idèjų vystymąsi ir pokyčius laiko dimensijoje. Laiko juostos principu sukurti modeliai populiarūs tarp menotyrininkų, tačiau naudojami ir kitose srityse, pavyzdžiui apibūdinti technologinę pažangą, ịvertinti istorinius, biografinius ịvykius. Vystymosi modeliai yra patogus įrankis vèlesniuose mokslininkų tyrimuose, padedantis organizuoti empirinę medžiagą, suvokti vykstančius procesus greta konkrečiai nagrinejjamos srities, taip pat ịvertinti pastebetas įtakas konkrečiam objektui (Grafton, et. al. 2010).

Viena iš koordinačių plokštumos ašių tokiuose modeliuose nurodo laiko dimensiją (šiame modelyje $\mathrm{X}$ ašis), kita ašis gali nurodyti bet kokią objekto ar nagrinejjamo atvejo savybę, kuri geriausiai atskleidžia nagrinejjamos raidos charakteristikas (šiame modelyje tai Y ašis). Nagrinejjant labai ilgą (šio tyrimo atveju - stilistinę) raidą tokio tipo diagrama yra segmentuojama ị atskirus skyrius, kurie vèliau yra aprašomi. Tokio pobūdžio tyrime objektai įvardinami remiantis tiek aprašomaisiais, tiek normatyviniais raidos tyrimais. Dèl modelio kūrimo specifikos, tie patys objektai gali kartotis dèl savo individualių savybių.

\subsection{Lietuvos architektūros stiliụ ir krypčių meninès raiškos modelis}

Remiantis disertacijos tiriamojoje dalyje apibūdintais stiliais ir kryptimis, bei jų meninès raiškos bruožais, galima apibūdinti nepriklausomus modelio klintamuosius:

1. Modernizmas (pagrindinis bruožas - forma pagal funkciją):

- Funkcionalizmas (nagrinejjamam laikotarpiui Lietuvoje būdinga tarptautinio stiliaus kryptis pasireiškianti atvira planine struktūra, laisva erdvine kompozicija, eksterjerų ir interjerų monochromija. žr. 1.1. skyrių);

- Regionalizmas:

a) kritinis regionalizmas (objektai pasižymi funkcionalistiniais formos kūrimo principais, tačiau atsižvelgia ị regiono charakterį arba kontekstą, ji interpretuoja. Taip pat pasižymi vietinių medžiagų naudojimu, žr. 1.2. skyriu);

b) tautiškumas (objektai pasižymi tiesiogine, vietinei architektūrai būdingų formų adaptacija arba stilizacija. žr. 1.2. skyrių).

2. Vèlyvasis modernizmas (pagrindinis bruožas - hiperbolizacija):

- Skulptūriškumas; 
a) plastiškumas (objektai pasižymi plastiškų formų naudojimu hiperbolizuojant modernistines formas, žr. 1.3. skyrių);

b) brutalizmas (objektai pasižymi betono plastikos naudojimu, isimintina, dominuojančia forma, konstrukcinès sąrangos eksponavimu pastato architektūrinèje raiškoje, hiperbolizuojant modernistines formas, žr. 1.3. skyrių).

- Geometrinè ekspresija;

a) Ekspresyvus formalizmas (objektai pasižymi ekspresyviu geometriniu formų naudojimu hiperbolizuojant modernistines formas, žr. 1.3. skyriu);

b) Formu priešprieša (objektai pasižymi ekspresyviomis priešingų formu sankirtomis arba kompozicijomis, hiperbolizuojant modernistines formas, žr. 1.3. skyrių).

- Pasikartojančių formų ritmika;

a) Struktūralizmas (objektai pasižymi artikuliuota erdvine tūrine sąranga, pasikartojančiais struktūriniais fragmentais, hiperbolizuojant modernistinę erdvinę - konstrukcinę sąrangą, žr. 1.3. skyrių).

- Techninè estetika:

a) High-tech (objektai pasižymi akcentuota metaline konstrukcija, nepridengtais konstrukciniais/inžineriniais ryšiais, metalo, plastiko, stiklo naudojimu, hiperbolizuojant modernistini funkcionalumo ir naudingumo konceptą, žr. 2.1. skyrių);

b) Slick-tech (objektai pasižymi aiškia, lakoniška geometrine forma arba jų kompozicijomis, žvilgančių paviršių estetika, žr. 2.1. skyrių);

c) Paviršiu autonomija (objektai pasižymi autonominiu paviršių traktavimu kuriant architektūrinę formą, žr. 2.1. skyrių).

3. Postmodernizmas (kompleksiškai naudojama dekoratyvi raiška ir interpretacija):

- Dekoratyvi raiška (Venturiškasis „,dekoruotos pašiūrès ${ }^{20 “}$ analogas, žr. 2.2. skyriu):

a) Eklektika (objektai pasižymi eklektišku dekoratyvių formų derinimu, žr. 2.2. skyriu);

b) Stilizacija (objektai pasižymi stilizuotomis dekoratyvinèmis detalèmis žr. 2.2. skyrių).

- Interpretacija (Venturiškasis ,,anties ${ }^{21 ، ~ “ ~ a n a l o g a s): ~}$

a) Istorizmas (objektai pasižymi stilizuotomis arba tiesiogiai taikomomis istorinėmis formomis, žr. 2.2. skyriu);

\footnotetext{
${ }^{20}$ angl. Decorated shed

${ }^{21}$ angl. The duck
} 
b) Kontekstualumas (objektai pasižymi kontekstualumu, stilizuojant dekoratyvinius elementus arba interpretuojant architektūrines formas, žr. 2.2. skyrių);

c) Simbolizmas ir semiotika (objektai pasižymi ženklų, simbolių, lengvai identifikuojamų formų interpretacijomis, humoru, ironija, žr. 2.2. skyrių).

2. Dekonstruktyvizmas (objektai pasižymi sudètingais, skaidytais tūriniais sprendimais, fragmentacijomis, įtampą kuriančiomis kompozicijomis, žr. 2.3. skyrių);

3. Minimalizmas („Less is more ${ }^{22 ،}$. Objektams būdinga aiški tūrinè kompozicija, lengvai isimenama forma, svarbus objekto ir aplinkos santykis, medžiagiškumas. Vertybiniai prioritetai: tyla, tuštuma, grynumas, vientisumas, aiškumas, paprastumas, žr. 2.3. skyrių).

Priklausomi modelio kintamieji, kaip jau minèta anksčiau, yra konkretūs objektai, kurių architektūrinejje formoje dominuoja pateikti meninès raiškos bruožai ir kūrybos konceptai.

Pirmoje modelio grafoje iš kairès žymimas stilistinis laikotarpis, suskirstytas i modernistinį, vėlyvojo modernizmo ir postmodernistinị. Grafa „,+“ apima dvi savarankiškas kryptis, nepriklausančias postmodernistinei ideologijai. Antroji, geltona spalva pažymèta grafa žymi pagrindini nagrinejjamo stiliaus meninès raiškos principą. Kaip išsiaiškinta pirmose 2 dalyse, modernizmui būdinga forma pagal funkciją, vèlyvajam modernizmui būdinga hiperbolizacija, postmodernizmas pasireiškia kompleksiška menine raiška. Tolesnèse grafose išdėstomi meninès raiškos bruožai ir architektūros kryptys. Viršutinejje grafoje žymima laiko juosta, punktyrinèmis linijomis segmentuojanti modelius.

Siekiant papildomo informatyvumo, grafinè modelio išraiška dalinama i 2 dalis, sudarant tekstinị (I) ir iliustracinị (II) modelius (žr. spalvotą ikliją). Tekstiniame modelyje didesnis demesys skiriamas svarbesnių objektų paminèjimui, išskiriant žymesnius vienos ar kitos krypties autorius, bei nurodant pagrindinius architektūros kūrinius, pažymimi objekto realizavimo metai ir miestas. Skirtingos kryptys žymimos skirtingomis spalvomis. Iliustracinis modelis kuriamas turint omenyje, jog ne visi modelyje minimi objektai yra gerai žinomi, gali būti sudètinga juos identifikuoti. Tuo tikslu iliustraciniame modelyje išdėstomos objektų iliustracijos, paminint tik autoriaus pavardę. Kiekviena kryptis taip pat išskirta atskira spalva, punktyrinès linijos žymi architektūrinès krypties raiškos pauzę. Nagrinejjant iliustracini modelị reikia atkreipti dèmesị ị rodyklių ir nuotraukų spalvinius žyejjimus. Ta pati spalva reiškia tą pačią architektūros kryptị.

22 „Mažiau yra daugiau“ - L. Mies van der Rohe 


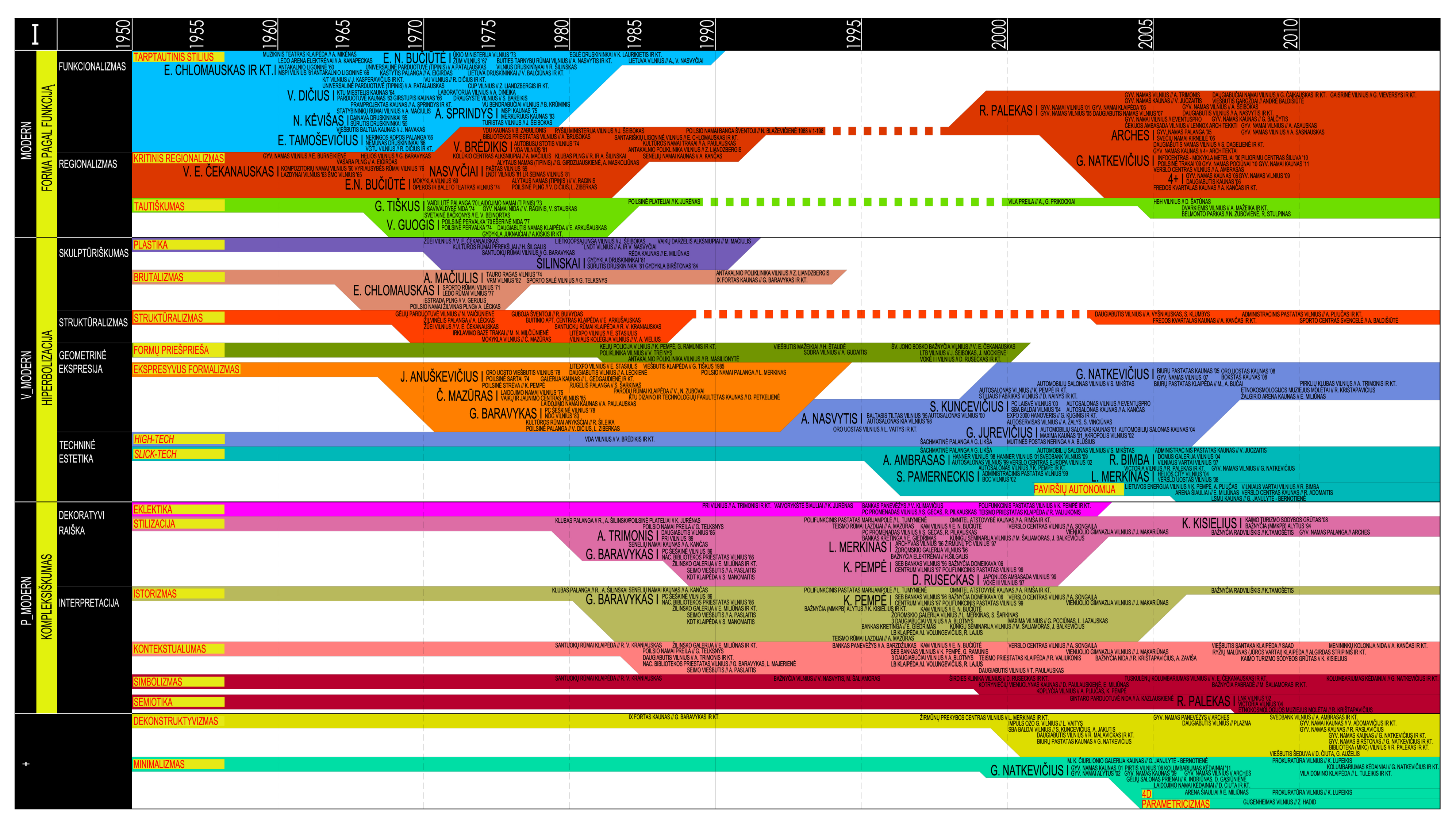




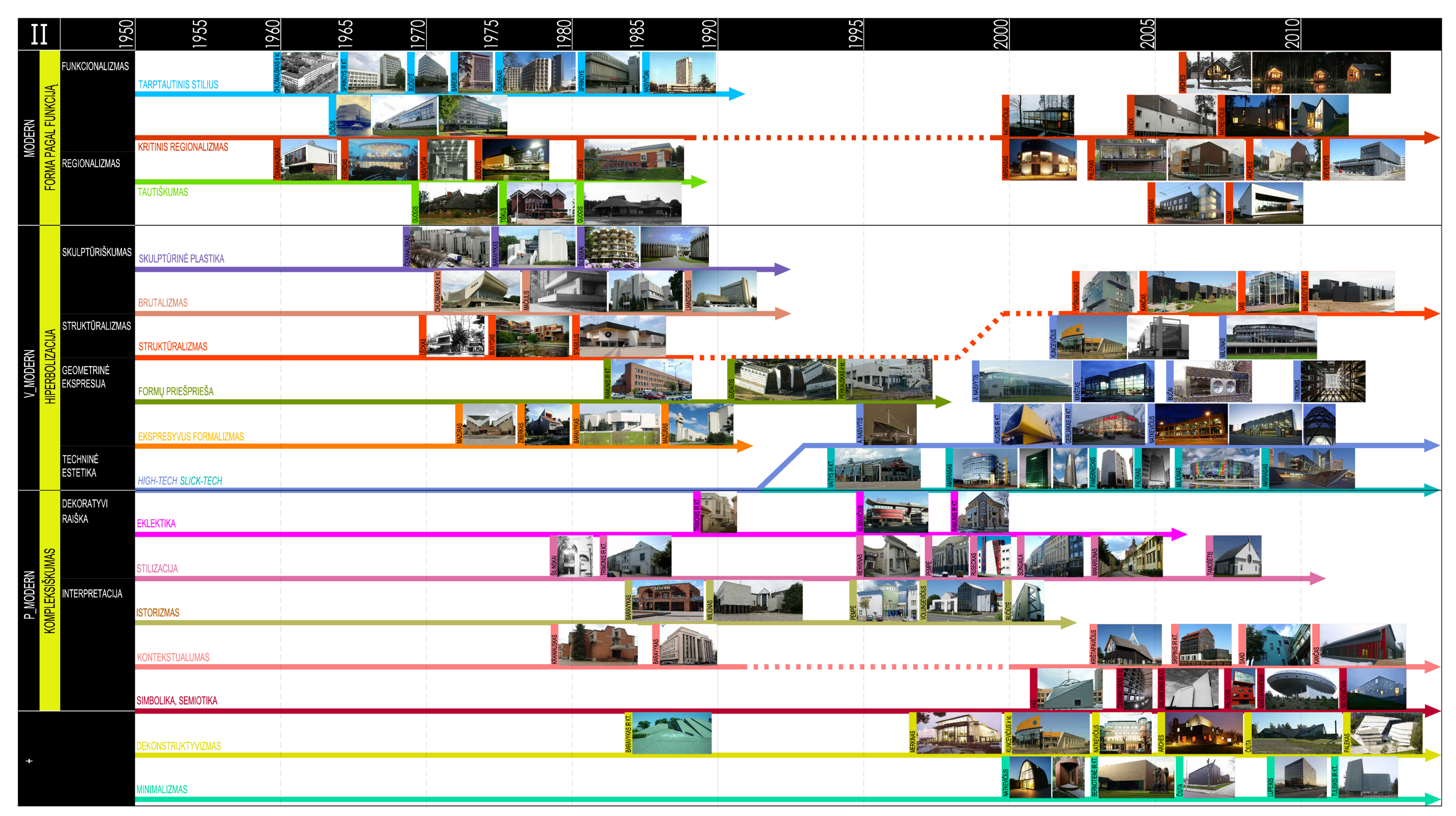


Praktinès kuriamo stilių ir krypčių modelio panaudojimo galimybès numatomos edukaciniais ir tolimesnių meninès raiškos tyrimų tikslais. Edukacijoje svarbus bendro architektūrinio konteksto pateikimas, grafinị modelị dékinga lyginti su kitų meno sričiu raidos modeliais (Dempsey 2004), numatant galimas sąsajas. Tokiu būdu architektūra nagrinejjama tarpdiscipliniškai, siejant ją su kitomis meno sritimis. Architektūros stiliai ir kryptys svarbios ir kitų mokslo šaku ir kypčių tyrinėtojams, pavyzdžiui, istorijos, kultūrologijos, socialinių mokslų.

\section{3. Šiuolaikinès Lietuvos architektūros meninè raiška pasauliniame kontekste}

Pasitelkus grafinę norminio raiškos modelio išraišką, galima atlikti keletą svarbių apibendrinimų, ịvertinančių šiuolaikinę Lietuvos architektūros meninès raiškos tendencijas. Tai bus įgyvendinama trimis etapais:

- nustatomi architektūros stiliai ir kryptys, kurios neturi arba turi menką itaką šuolaikinei Lietuvos architektūrai;

- nustatomi architektūros stiliai ir kryptys, kurios aktyviai prisideda prie šiuolaikinès architektūros meninès raiškos formavimo;

- nustatomi architektūrinès raiškos bruožai, formuojantys šiuolaikines architektūros tendencijas, įvardinama stilistinè ịtaka;

- gauti rezultatai palyginami su panašaus pobūdžio užsienio architektūros meninès raiškos tyrimais.

Funkcionalistinė architektūros raiška, šeštajame XX a. dešimtmetyje, kaip minèta pirmajame skyriuje, visų pirma pasireiškè tarptautinio stiliaus estetika, turinčia tarpukario funkcionalizmo bruožų. Vèliau galima įžvelgti šios krypties grynumo laikotarpi, kurio metu suprojektuota nemažai vienetinių ir tipinių objektų - universalinių parduotuvių, mokyklų, darželių. Tarp žymesnių autorių ligonines projektavę E. Chlomauskas ir Z. Liandzbergis, Kaune kūrę V. Dičius ir A. Sprindys, poilsio namus ir viešbučius projektavę N. Kèvišas ir E. Tamoševičius.

Antrojoje aštunto dešimtmečio pusèje funkcionaliojoje architektūroje pastebima daugiau plastikos elementų, skulptūrinès puošybos. Konstruktyviniai elementai pradedami naudoti kaip ornamentai siekiant paivvairinti monotonišką architektūrinę raišką, unifikuotos konstrukcijos iggavo skulptūriškumo, plastikos. Tokiu būdu pradèta hiperbolizuoti pati pastato struktūra, paverčiant ją ornamentu. Šiuo laikotarpiu (XX a. aštuntojo deš. antroji pusè) modernizmo architektūroje apskritai, pastebimos modernistinių formų hiperbolizacijos tendencijos, intensyvesnè nei prieš tai plastišku ir geometrinių formų meninè raiška architektūros tektonikoje. Tarptautinio stiliaus interpretacijų galima aptikti ir 
šiuolaikinèje architektūroje, tačiau tai daugiau imitacija nei nuosaiki architektūrinès krypties tąsa.

Regionalioji moderniosios architektūros kryptis Lietuvos architektūroje pastebima nuo pat tarptautinio stiliaus formų adaptacijos. Perèmęs visus funkcionalizmo projektavimo principus kritinis regionalizmas praturtino tarptautinio stiliaus meninę raišką vietinèmis medžiagomis, pagarba kontekstui ir vietinès architektūros formoms, taip pat pasiūlè įvairesnių formų kompozicijas. Ankstyvuosiuose šios krypties pavyzdžiuose matoma suomiu modernizmo ir A. Aalto itaka (ankstyvieji V. E. Čekanausko darbai), vèlesniuose - plastiškų ir skulptūrinių formų sąveika (Operos ir baleto teatras, archit. E. N. Bučiūtè). Pagarba kontekstui ir atsakinga gamtinès situacijos analize unikalus Lazdynų mikrorajono urbanistinis sprendimas (archit. V. E. Čekanauskas, V. Brèdikis 1965 m.), nuosaikumu istorinejje aplinkoje pasižymi V. ir A. Nasvyčių projektuoti Nacionalinis dramos teatras Vilniuje $(1981 \mathrm{~m}$.) ir Centrinis paštas, Vilniuje (1969 m.). Vietinių formų interpretacija matoma ir masiškai išplitusiuose tipiniuose Alytaus namų projektuose (archit. G. Girdzijauskienè, A. Maskoliūnas 1975 m., ir V. Raginis 1976 m.).

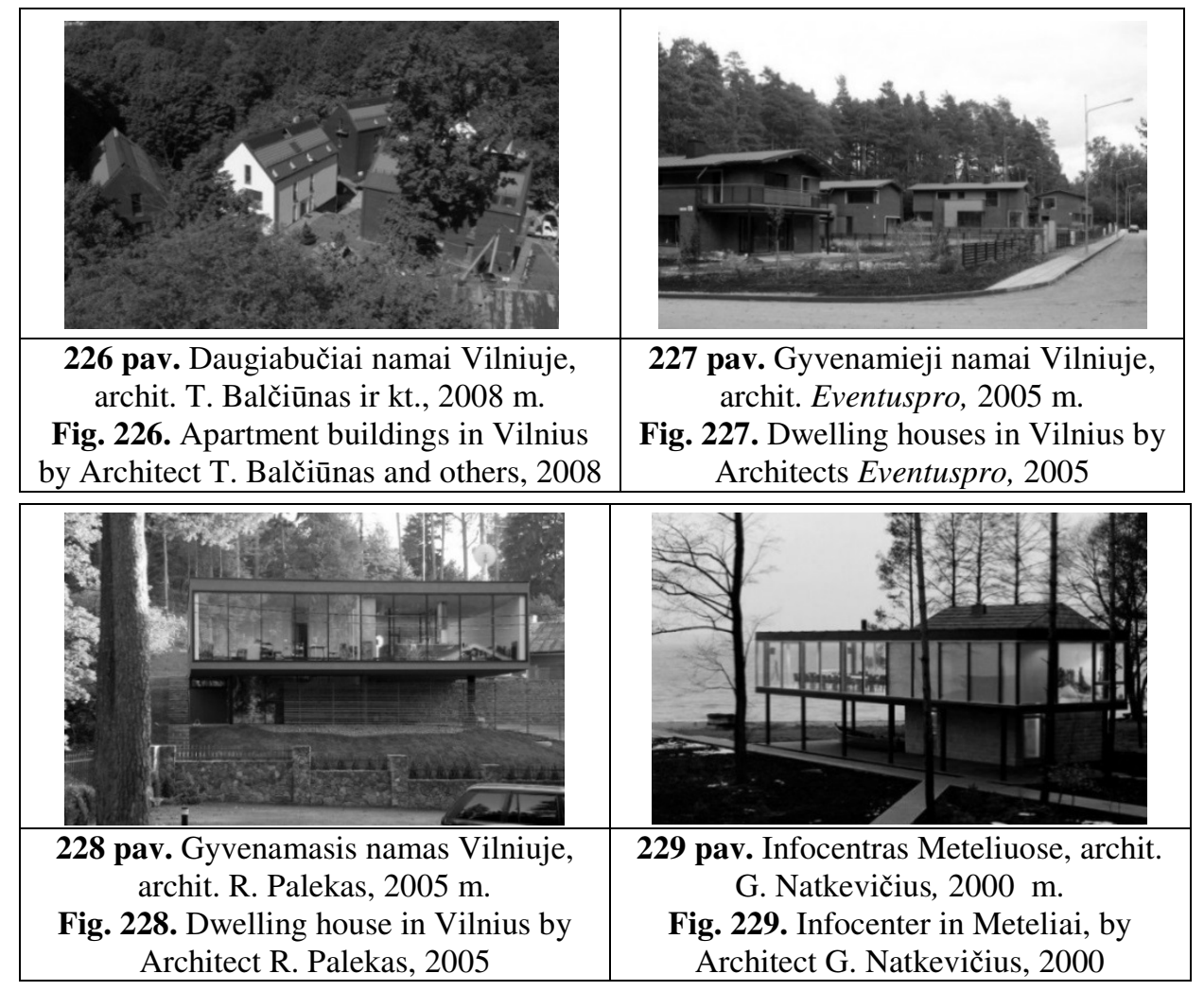


Visą paskutinị XX a. dešimtmetị kritinis regionalizmas buvo užleidęs vietą postmodernistinei architektūros raiškai, tačiau šiuolaikinejje architektūroje vèl pastebimos šios krypties tendencijos. Regioninis charakteris funkcionalumo principais paremtoje architektūroje atsispindi sąsajų su kontekstu paieškose (gyv. namų kvartalas Nugalètojų g., Vilniuje, archit. R. Palekas 2001 m., daugiabučių kvartalas Krivių g. Vilniuje, archit. T. Balčiūnas ir kt. 2008 m. (226 pav.), ir kt.), taip pat naudojant vietinei architektūrai būdingas medžiagas (gyv. namų kvartalas Vilniuje, archit. „Eventuspro“, 2005 m. (227 pav.), gyv. namas Vilniuje, archit. R. Palekas, $2005 \mathrm{~m}$. (228 pav.), Meteliu regioninio parko infocentras, archit. G. Natkevičius, 2000 m. (229 pav.) ir kt.).

Tautinès architektūros kryptis Lietuvos architektūroje matoma nuo aštuntojo deš. pr. Žymesni šios krypties atstovai, kūrę dažniausiai rekreacinius objektus G. Tiškus ir V. Guogis. Išskirtiniai yra G. Tiškaus suprojektuoti tipiniai laidojimo namai (1973 m.), papuošti tautine ornamentika, skulptūriniais lipdiniais. Lyginant moderniojo laikotarpio tautinę architektūrą, su šiuolaikine, skirtumų pastebima nedaug, to priežastimi galime laikyti faktą, jog tiek projektavimo principai, tiek pastatu paskirtis išliko beveik nepakitusi. Šiuolaikineje tautiškoje architektūroje šiek tiek daugiau kičo elementu, perimtų iš postmoderniojo laikotarpio, taip pat gausiau naudojama ornamentika. Šiuolaikinè tautiška architektūra susijusi su užsakovo norų tenkinimu, griežtais naujos architektūros kraštovaizdžio draustiniuose reikalavimais, rečiau, su architekto kūrybos principais.

Vèlyvojo modernizmo plastiškumas pastebimas H. Silgalio, G. Baravyko, J. Šeiboko darbuose. Greta plastiškų modernizmo formų epizodiškai matoma brutalizmo estetika, kuri pastebima sporto kompleksų architektūroje, visuomeniniuose, kultūriniuose, epizodiškai ir rekreaciniuose šio laikotarpio objektuose (A. Mačiulio, E. Chlomausko ir Z. Liandzbergio, A. Lècko darbai). Brutalizmo estetinę raišką galima įžvelgti ir pavieniuose šiuolaikiniuose objektuose, dažniausiai ten, kur naudojama atviro betono estetika, tačiau tai greičiau šiuolaikinių Japonų architektų ịtaka, o ne architektūrinès - konstrukcinès sąrangos hiperbolizacijos.

Ekspresyvi geometrinių formų raiška hiperbolizuojant modernistines formas pastebima visuomeniniuose, rekreaciniuose objektuose, žymesni šio laikotarpio autoriai: J. Anuškevičius, Č. Mazūras, G. Baravykas, E. Stasiulis. Kai kurie sprendimai savo planine struktūra pradeda priminti postmodernistinius, tai ypatingai pastebima, kuomet pirminès geometrinès formos derinamos su plastiškomis. Tokių objektų pavyzdžiais galètų būti Vilniaus kelių policijos pastatas (archit. K. Pempe ir kt. 1982 m.), Sodros administracinis pastatas (archit. A. Gudaitis 1993 m.), ir kt. Dominuojanti geometrinių, taip pat ir plastiškų formų estetika pastebima ir ankstyvuoju postmodernistiniu laikotarpiu, tik tuo pačiu papildoma ịvairiais postmodernistiniais elementais - stilizuotomis istorinemis formomis, eklektiškais dekoratyviniais elementais. 
Hiperbolizuotomis erdvinèmis struktūromis pasižymi struktūralizmas vèlyvojo modernizmo kryptis, akcentuojanti iš pasikartojančių elementų sudarytas kompleksiškas kompozicijas. Lietuvoje tai pastebima maždaug nuo septintojo dešimtmečio pabaigos iki pat 1990-ujjų. Šiuolaikinèje architektūroje tai vèl matoma daugiabučių, kotedžų kompleksuose, taip pat iš modulių sudarytose architektūrinèse kompozicijose (Fredos gyvenamujų namų kvartalas Kaune, archit. A. Kančas 2005 m., Mokslo technologijų parkas Vilniuje, archit. „VAS“, 2007 m. (230 pav.), Svencelès sporto kompleksas, archit. A. Baldišiūtė ir kt., 2010 m. (231 pav.), ir pan.).

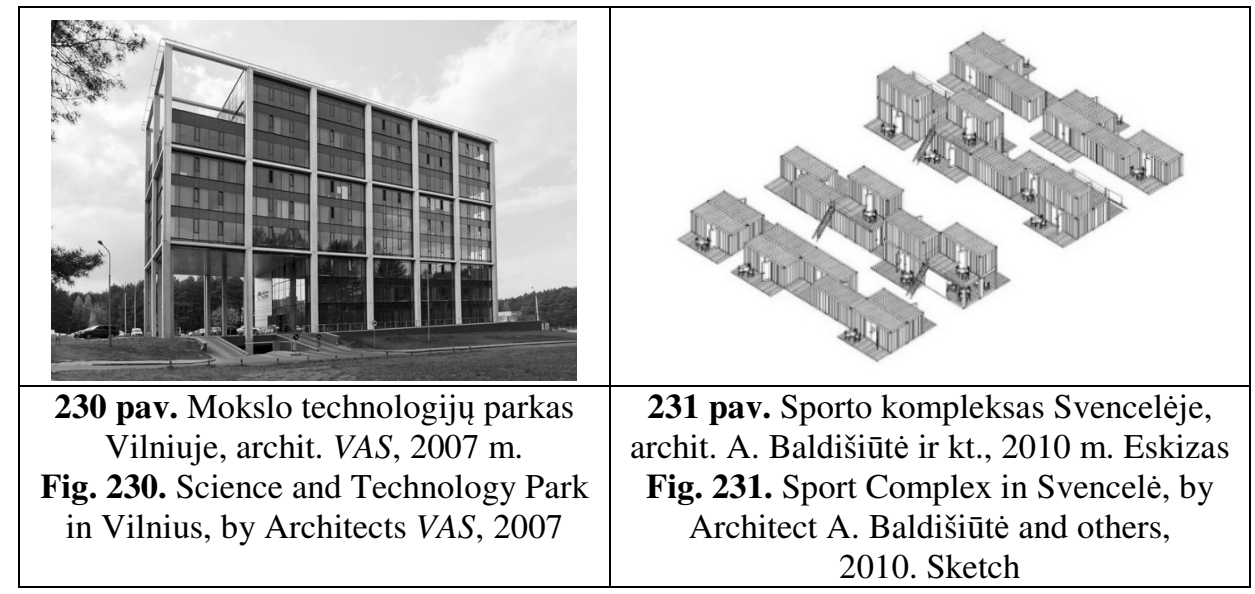

Vèlyvojo modernizmo hiperbolizacijoms priskiriama ir techninè estetika high-tech ir slick-tech architektūra. Unikalu yra tai, jog Lietuvoje šios kryptys isitvirtino su antraja postmodernizmo banga, maždaug nuo 1995-ujų. Tiesa, reikia paminèti, jog epizodiškai high-tech elementai moderniojoje architektūroje buvo pastebimi nuo pat septintojo dešimtmečio, pavyzdžiui, Vilniaus centrinio pašto interjere, archit. V. ir A. Nasvyčiai 1969 m., Vilniaus Dailès akademijos naujojo korpuso tiltelio architektūriniame sprendime 1981 m., ir kt. Lietuvos architektūroje high-tech principai ịsitvirtino kiek pakitę, dažniau pastebimi interjeruose, didelio tarpatramio architektūriniuose objektuose, kur nepridengti konstrukciniai ir inžineriniai elementai buvo eksponuojami kaip estetinis sumanymas. High-tech estetika šiuo metu naudojama ir kartu su slick-tech paviršiais, betono estetika, dažnai reprezentuojant utilitarią pastato paskirti. Hightech architektūrai būdinga meninè raiška dažniausiai pastebima visuomeninès ir specializuotos paskirties objektuose, autoservisuose (pavyzdžiui, A. Nasvyčio, S. Kuncevičiaus, G. Jurevičiaus, G. Natkevičiaus projektuoti autosalonai).

Slick-tech, kaip atskira architektūros kryptis Lietuvoje susiformavo tik pradejjus vystyti dešiniojo Neries kranto urbanistinę koncepciją, todèl nuo pat 2000-ujų, matomas susidomejjimas šia meninès raiškos kryptimi. Savaime 
suprantama, jog susidomejjimą sustiprino ir iki tol nenaudotos paviršiu raiškos galimybès. Kaip ir visame pasaulyje, taip ir Lietuvoje slick-tech paviršiu raiška visų pirma pastebima administraciniuose pastatuose, projektuotuose A. Ambraso, S. Pamerneckio, R. Bimbos, L. Merkino ir kt. Iš norminio raiškos modelio matyti, jog ši kryptis dar neprarado susidomejjimo, kadangi visos paviršių raiškos priemonès Lietuvos architektūroje dar nèra išnaudotos.

Šiuolaikinèje architektūroje, pastebima paviršių autonomija, kuomet išorinis pastato sluoksnis kuria naują pastato formą, arba ją pabrěžia. Lietuvoje autonomine paviršių raiška kol kas siejama tik su paviršių dualumu, t. y. specialiais šviesą atspindinčiais stiklais (Šiaulių arena, archit. E. Miliūnas, 2006 m.), taip pat ịvairiais stiklų dekoravimo būdais (Lietuvos energijos pastato rekonstrukcija, Vilniuje, archit, K. Pempè, 2004 m., verslo centras Kaune, archit. R. Adomaitis, 2008 m.). Tačiau plintant medijoms ir 4D vizualinei raiškai, ši tendencija turi raiškos galimybių plètotis.

Pirmieji postmodernizmo ženklai Lietuvos architektūroje pastebimi vèlyvojo modernizmo laikotarpiu, aštuntajame dešimtmetyje, kuomet funkcionali pastato planinè - erdvinè sandara pradèta puošti stilizuotomis istorinèmis formomis arkomis, kapiteliais ir bokšteliais. Iki 1990-ujų postmodernizmas Lietuvos architektūroje reiškèsi išskirtinai istorinių formų stilizacijomis ir tūrinemis interpretacijomis. Šiuo laikotarpiu kūrè A. Trimonis, G. Baravykas, E. Miliūnas. Nuo dešimtojo dešimtmečio vidurio postmodernistineje raiškoje pradedamos naudoti ịvairesnès ir gausesnès medžiagos, jų deriniai, istorinių formų interpretacijos tampa manieringesnès, sudètingesnès, labiau eklektiškos.

Kontekstualumas aptariamu laikotarpiu taip pat labai svarbus, tačiau dažniau pastebimas istorineje, pavyzdžiui senamiesčio, aplinkoje, stilizuojant aplink matomus istorinius elementus - karnizus, balkonus, erkerius ir nišas. Tiesa, galima rasti ir išskirtinių pavyzdžių, tai E. N. Bučiūtès projektuotas Krašto apsaugos ministerijos, centrinis gynybinis štabas Vilniuje (1996 m.), taip pat Lietuvos banko saugykla Klaipèdoje (archit. J. Volungevičius, R. Lajus, (1996 m.), ir kt. Simbolika, ženklų bei metaforų kalba dažniausiai matoma sakralinių pastatų architektūroje (su keliomis išimtimis), siejama su brandesniu postmodernistinès architektūros suvokimu.

Dekonstruktyvizmas, kaip savarankiška architektūros kryptis Lietuvoje neįsitvirtino, tai galima sieti su šios krypties meninès raiškos komplikuotumu ir didelèmis realizacijos sąnaudomis. Užsienio architektūroje dekonstruktyvizmas yra siejamas su CAD programų naudojimu ir paplitimu, o kadangi skaitmeniniai formų modeliavimo principai išliko, buvo perimti ir kai kurie dekonstruktyvistinès architektūros tūrių modeliavimo aspektai. Tai matoma kai kuriuose žymesniuose šiuolaikinès Lietuvos architektūros objektuose, pavyzdžiui, „Swedbank“ pastate Vilniuje, archit. A. Ambrasas, 2009 m., taip pat 
Mokslinès komunikacijos ir informacijos centre, Vilniuje, archit. R. Palekas ir kt., 2013 m. ir kituose.

Minimalistine architektūros kryptis Lietuvoje yra viena iš labiausiai progresuojančių. Šio amžiaus pradžioje epizodiškai pastebima tik individualių namų architektūroje, kai kuriuose mažosios architektūros objektuose, po dešimties metų matoma ir visuomeninių objektų architektūrinejje raiškoje. Tiesa, lietuviškasis minimalizmas išskirtinai pirminių geometrinių formų, dažnai naudojant šiai krypčiai būdingas minimalias meninès raiškos priemones pragmatiškumo sumetimais, o ne siekiant architektūrinès idejos grynumo. Vis dèlto, atsižvelgiant $i$ tai, jog visame utilitarios minimalistinès raiškos kontekste atsiranda objektų, sukurtų vadovaujantis minimumo idejjomis, taip pat regint šios krypties sąsajas su skaitmeniniais projektavimo įrankiais, galima daryti prielaidą, jog minimalistine kryptis turi tendencijų plètotis.

Šiame tyrime sukurtas norminis meninès raiškos modelis gali būti naudojamas vertinant Lietuvos architektūrą bendrame XX a. moderniosios architektūros kontekste. Palyginimui pasitelkiami Charles Jencks sukurti Moderniosios architektūros evoliucijos medis (Jencks 2000) (232 pav.), Vèlyvojo modernizmo meninès raiškos modelis, ir postmodernizmo meninès raiškos modelis (Jencks 1982), taip pat Paul Makovsky (Makovsky 2011) sukurtas modelis. Šie modeliai pasirenkami, nes yra pagristi normatyvinèse studijose.

$\mathrm{XX}$ a. architektūros gija nepriklauso kokiam nors pastato tipui, judejimui, asmeniui, nèra nulemta kokios nors pramonès šakos. Atvirkščiai, ji priklauso idèju kaitai, dinamikai, pastoviam naujų konceptų srautui, socialinių judèjimų, techninių galimybių ir asmenybių balansui. Tiesa, kad kai kurie praejjusio šimtmečio architektai formavo naujas raiškos tendencijas, kai kada netgi kelias vienu metu. Le Corbusier, Frank Lloyd Wright, Alvar Aalto, su Mies van der Rohe sudare didiji ketvertą, davusị impulsą vèlesniajai kartai - Louis Kahn, James Stirling, Peter Eisenman ir Frank Gehry (Jencks 2007), kurių kiekvienas turejjo savo įtakos laikotarpius, tačiau cikliškai keitè savo kūrybos principus, ir dare tai kas maždaug 10 metu.

Le Corbusier galètų būti to cikliškumo pavyzdys. Trečiojo dešimtmečio pradžioje jis buvo naujosios architektūros pradininku, vèliau kryptingai vystè urbanistinius projektus, pokario metais sprende iškilusias apgyvendinimo problemas, šeštajame dešimtmetyje suprojektavo absoliučiai iracionalią Ronchamp koplyčią, taip duodamas impulsą brutalistinei architektūrai, o ir apskritai simbolizmui architektūroje, o savo aktyvios kūrybos pabaigoje netgi suprojektavo ir keletą high-tech architektūrai priskiriamų pavilijonų.

Visi šie pokyčiai tèra besitęsiančios architektūrinès evoliucijos dalis, architektūrinès kryptys neturi pradžios ir pabaigos, visos jos yra pastovaus kitimo rezultatas. Bet kuriuo laiku, XX-ajame amžiuje kuriantis architektas dirba 3-4 architektūros krypčių ịtakoje, tuo pat metu reaguoja ị socialinius, technologinius, 
kartais ideologinius pokyčius, tarp kurių pasauliniai karai ar net internetas. Ch. Jencks modelio apačioje išskyrè grafą, kurioje nurodé, jog net $80 \%$ architektūros yra nulemta aplinkybių, t. y. tokią dali architektūros sukuria net ne architektai, o, pavyzdžiui, teisès aktai ir planavimo koncepcijos, globalizacija, tvarios plètros idejos ir pan. (Jencks 2007).

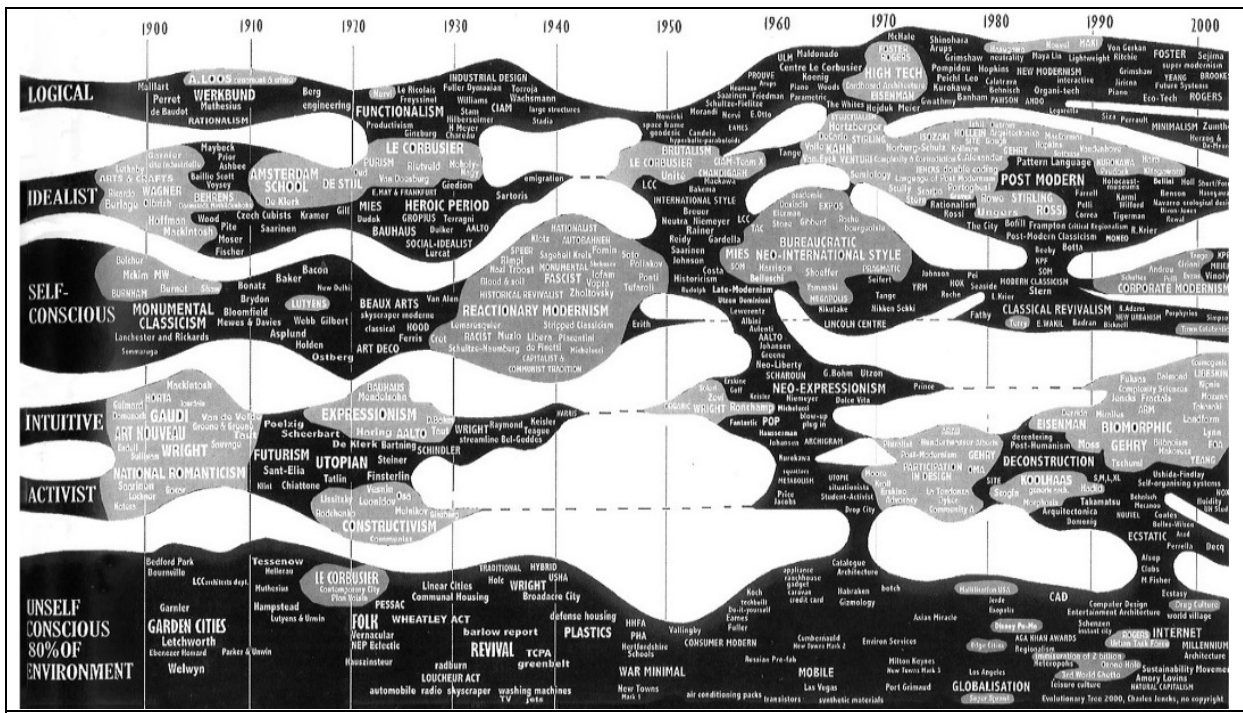

232 pav. Moderniosios architektūros evoliucijos medis, Ch. Jencks, $2000 \mathrm{~m}$.

Fig. 232. Evolutionary Tree of Modern Architecture by Ch. Jencks, 2000

Šiame pliuralistiniame XX a. moderniosios architektūros modelyje galima atrasti apie 60 skirtingų krypčių, didelè dalis jų, po ilgesnès ar trumpesnès pauzès atgimsta „neo“, ar ,post“ pavidalu. Lietuvos architektūrą šiame kontekste galima vertinti pragmatiškiau. Iki pat 1990-ujų ịtakojama išskirtinai politinių faktorių, Lietuvos architektūrinè evoliucija yra greičiau logiška ir idealistinè, nei intuityvi ar aktyvistine. To pasekoje Dekonstruktyvizmo, kaip atskiros krypties bruožai pastebimi 10-15 metų vèliau nei pasaulinèje architektūroje, o tokių krypčių kaip futurizmo, utopizmo, neo-ekspresionizmo, pop, metabolizmo apraiškas apskritai sudètinga identifikuoti. Vidurinè grafa Ch. Jencks modelyje reprezentuoja vyraujančią krypti, daugiausia vadinama îvairiomis klasicizmo atmainomis. Lietuvoje tai galima sieti su retrospektyviniu istorizmu, pasibaigusiu politiniais nutarimais 1955-aisiais, ir ịvairaus pobūdžio istoristiniu kiču, atgimusiu postmodernistiniu laikotarpiu. Reikètų atkreipti dėmesi $i$ tarptautinio stiliaus vietą nagrinejjamame modelyje, kuris viduryje sujungia vyraujančios krypties, idealistinę ir loginę grafas. Ch. Jencks tarptautinị stilių ịvardina kaip kapitalistinį, pragmatišką, tinkantị spręsti apgyvendinimo problemas, parankų korporacijoms, todèl savaime tinkantị būti vyraujančia kryptimi. Ir nors meninè šios krypties raiška radikaliai skyrèsi nuo, pavyzdžiui, istorizmo, tarptautinis stilius 
vaizduojamas greta. Lietuvoje susikloste identiška situacija, tiesiog tarptautinis stilius čia atitiko politines nuostatas, todèl prieš tai dominavęs retrospektyvizmas pakeistas visiškai priešingos meninès raiškos kryptimi, kuri tapo vyraujančia.

Vèliau sekusios, viršutinèje modelio dalyje esančios architektūros kryptys, su keliomis išimtimis, vienu ar kitu laikotarpiu matomos ir Lietuvos architektūroje, tiesa, absoliuti dauguma jų pasirodè véliau. Vèlyvojo modernizmo brutalistinè kryptis Lietuvoje matoma tik nuo aštuntojo deš. pradžios (vèlavo apie 20 metu), Taip pat, ir high-tech, ir slick-tech estetika. Struktūralizmas atsiliko 10-čia, postmodernizmas - 20-čia metų. Minimalistinè raiška, pozicionuojama greta idealistinès grafos, tačiau kilusi iš loginès taip pat atspindi bendras šios krypties tendencijas Lietuvoje, o ir laikotarpis skiriasi nežymiai. Po 1990-ųjų metų Lietuvos architektūroje pastebima vis daugiau įtakos iš paskutiniosios, periferinès modelio grafos, teigiančios, jog $80 \%$ architektūrinių objektų paremta su architektūra nesusijusių idèjų, tai ir ekologija, pasyvūs namai, CAD programos, tvari plètra ir pan.

Vèlyvojo modernizmo hiperbolizacijas ir postmodernizmo kompleksiškumą Ch. Jencks nagrinejjo atskirai, kiekvienam šių laikotarpių sukūręs po norminị meninès raiškos modelị $(233,234$ pav.). Palyginus šiuos modelius su kuriamu šiame tyrime, nustatyta, jog vèlyvojo modernizmo laikotarpiu Lietuvos architektūroje dominavo formalusis šio stiliaus pradas. Ivvairių tūriu ir formų hiperbolizacijos persipynusios su struktūralizmo tendencijomis reprezentavo pasaulinę vèlyvojo modernizmo architektūrą ekspresyviomis skulptūrinėmis, išraiškingų geometrinių tūrių kompozicijomis. Tokios architektūros kryptys kaip high-tech ir slick-tech Lietuvoje pasirodè tik po 1990-uju, o vèlyvojo modernizmo erdvès improvizacijų, pavyzdžiui naudojant mastelini tinklą ${ }^{23}$ arba kuriant megastruktūras, improvizacijų funkcionalizmo tema (užsienio architektūroje tai matoma R. Meyer, J. Hejduk kūryboje) nèra identifikuota.

Postmodernistinèje Lietuvos architektūroje, taip pat kaip ir užsienio, didesnę meninès raiškos dalị sudaro istoristinès formos ar tiesioginis stilizuotų istorinių elementų naudojimas. Tačiau skirtingai nei užsienio architektūroje, Lietuvoje urbanistinis postmodernistinès erdvès kūrimas siejamas ne su tautinès ${ }^{24}$ architektūros formų interpretacijomis (Ch. Jencks modelyje šios dvi grafos susijungia), o su tomis pačiomis stilizuotomis istorinemis formomis ar jų kompozicijomis. Ženklų ir metaforų kalba postmodernistinèje Lietuvos architektūroje plètota menkai, pradžioje pastebimi pavieniai bandymai sakralinèje architektūroje, vèliau, visuomeniniuose objektuose, tačiau tokios meninès raiškos, būdingos SITE, S. Tigerman, arba K. Yamashita ir kitiems antropomorfistams pasiekta nebuvo.

\footnotetext{
23 angl. Grid

24 angl. Neo Vernacular
} 


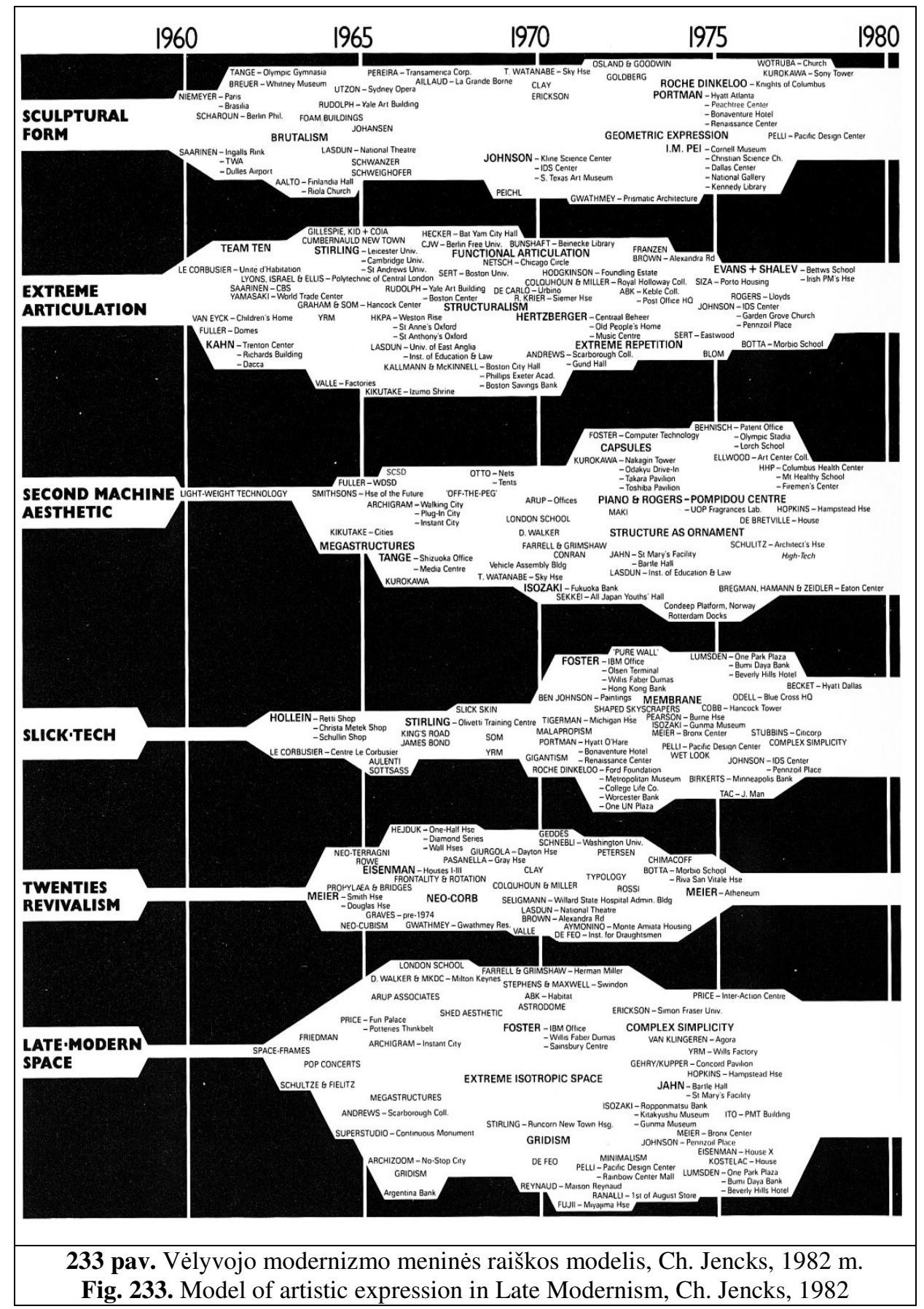




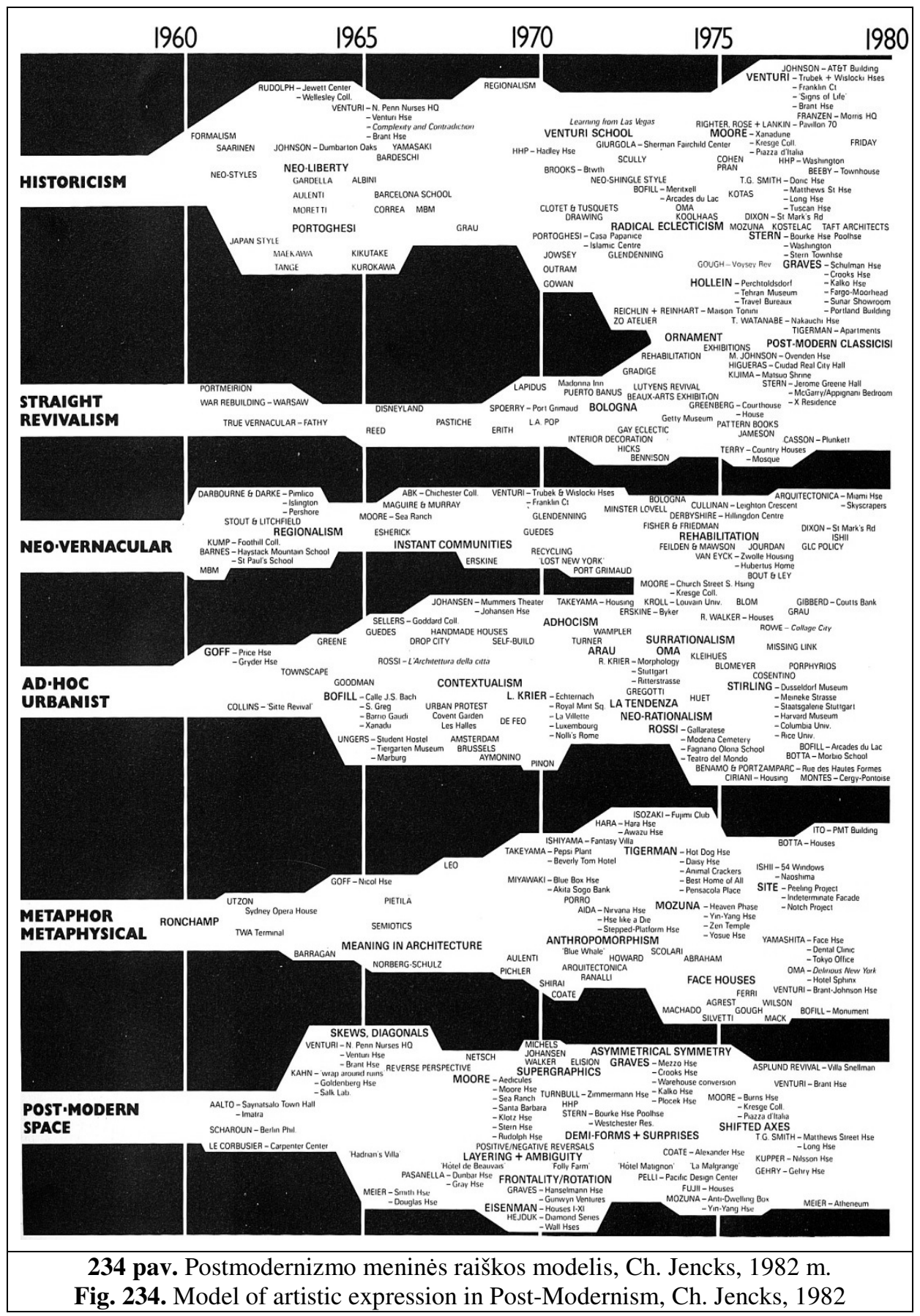


Paul Makovsky šiuolaikinès architektūros krypčiu modelyje (235 pav.), meninès raiškos požiūriu, svarbios dekonstruktyvizmo, blobizmo ir minimalizmo grafos. Iš jų pastebimas dekonstruktyvistinès architektūros pozicijų silpnejimas, blobizmo ir minimalizmo tendencijų stiprējimas XXI a. pradžioje. Blobizmą, kaip individualią architektūrinę kryptị Lietuvos architektūroje kol kas išskirti sunku, tačiau ši kryptis, paremta skaitmeniniais modeliavimo procesais, pasižyminti nebaigtos, kintančios formos transformavimo galimybėmis, turi tendencijų plètotis.

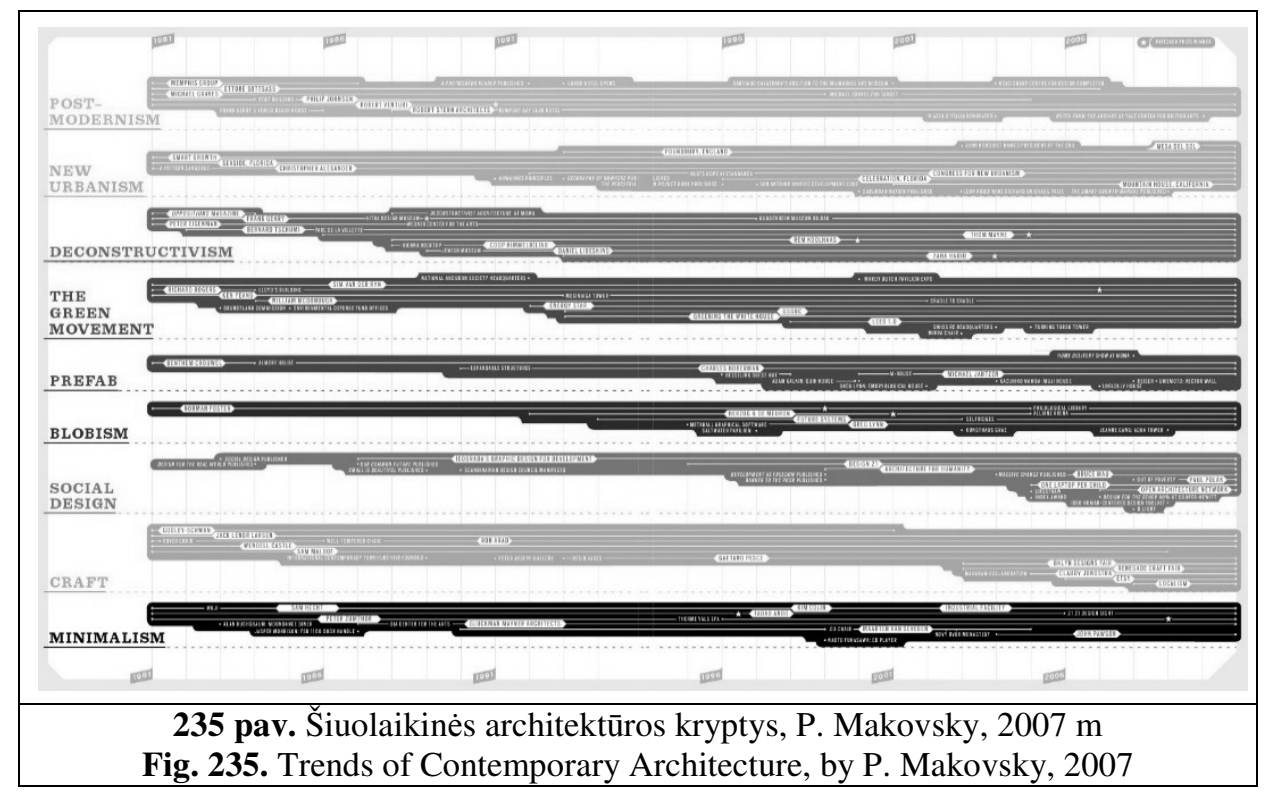

\subsection{Trečiojo skyriaus apibendrinimai}

1. Normatyvinis Lietuvos architektūros stilių ir krypčių modelis skirsto Lietuvos architektūros meninę raišką ị tris pagrindinius stilius: modernizmą, vèlyvaji modernizmą ir postmodernizmą. Šiuose stiliuose pastebimos architektūros kryptys būdingos ir užsienio architektūrai, skiriasi tik jų meninès raiškos bruožai ir palitimo laikotarpis.

2. Lyginant Lietuvos architektūros stilių ir krypčiu modelị su užsienio tyrinètojų sukurtais modeliais, pastebima logiškumu ir idealistinemis nuostatomis paremta architektūrinè evoliucija, tik Lietuvoje tai reiškia politinius motyvus, o užsienyje - ekonominius ir socialinius. Užsienio architektūroje vykę pokyčiai dažnai pasikartodavo ir Lietuvos architektūroje, tik kitame sociokultūriniame kontekste. XX a. antrosios pusès architektūros teorijų lankstumas, meninès 
raiškos priemoniu gausa, leido joms lygiavertiškai reikštis įvairiose politinėse ir kultūrinèse santvarkose. Moderniosios architektūros universalumas, besireiškiantis įvairiuose kontekstuose, pasirode tinkamas spręsti skirtingas užduotis, tuo pačiu suteikè teigiamus impulsus šiuolaikinès architektūros kryptims, pasižyminčioms universalumu, transformacijomis, prisitaikymo ir pritaikymo galimybėmis. 



\section{Bendrosios išvados}

1. Modernioji pokario architektūra Lietuvoje įsitvirtino pragmatiškomis sąlygomis, kurias lèmé politiniai ir ideologiniai sprendimai, taip pat pasikeitę apgyvendinimo poreikiai. Šiuo laikotarpiu gausèjo tipinès statybos objektu, kuriems tiko paprastas, universalus ir funkcionalus stilius. Lietuvos architektai vietiniam kontekstui pritaikè tarptautinio stiliaus ${ }^{25}$ formas, funkcionalią estetiką. Tarptautinis stilius, užsienio architektūroje tarnavęs korporacijoms, masinei statybai, Lietuvoje igavo dvasinę dimensiją, atsiradusią kaip prieštara prieš tai vyravusiam retrospektyviniam istorizmui. Šio laikotarpio architektūra 8 dešimtmečio viduryje dekoratyvejjo, architektai naudojo struktūrinius elementus kaip ornamentiką, pradejo ieškoti imantresnių architektūrinès išraiškos priemonių.

2. Vèlyvasis modernizmas Lietuvos architektūroje pasižymi daugiausia formaliuoju stiliaus aspektu - modernizmui būdingų formų, planinès struktūros, funkcionalumo hiperbolizacijomis. Vèlyvojo modernizmo pradžia Lietuvoje galima laikyti plastiškų, brutalistinei estetikai būdingu formų naudojimą. Nors pasaulinejje architektūroje brutalizmas naudojo ịvairias raiškos priemones, Lietuvoje ši architektūros kryptis išskirtinai monumentali, skulptūriška. Vèlesniu laikotarpiu matomos iracionalumo ir dekoratyvumo tendencijos, paplito plastiškų, skulptūrinių elementų naudojimas. Hiperbolizuotos vèlyvojo modernizmo formos

25 angl. International style 
matomos jau ir postmodernistiniu laikotarpiu, papildytos stilizuotais dekoratyviniais elementais, o viena iš vélyvojo modernizmo krypčių struktūralizmas turi tiesioginių sąsajų su šiuolaikine architektūra.

3. Regioninio charakterio paieškos moderniojoje Lietuvos architektūroje sietinos su šiaurinių kaimynų Suomių moderniosios architektūros ịtaka. Šiuo laikotarpiu matoma išaugusi konteksto suvokimo svarba, vietinei architektūrai charakteringu medžiagų panaudojimas, vietos, o ne erdvès konceptas architektūroje, kuris vietomis peraugo i tautiškumą, tiesiogines tradicinès architektūros interpretacijas, kitur igavo kritinio regionalizmo bruožų. Šios krypties meninè raiška, papildyta postmoderniosios architektūros medžiagiškumu pastebima ir šiuolaikinejje architektūroje.

4. Vèlyvojo modernizmo techninè estetika, pasižyminti struktūrinių, konstrukcinių sprendimų hiperbolizacijomis, užsienio architektūroje matoma nuo aštuntojo praejusio amžiaus dešimtmečio pradžios. Lietuvos architektūroje, neskaitant pavienių atvejų, nuo paskutiniojo praejjusio amžiaus dešimtmečio vidurio. Šis laiko skirtumas sąlygojo pakitusią techninès estetikos meninę raišką, dažnai naudojamą kitų raiškos priemonių kontekste, siekiant išskirti ar akcentuoti vieną ar kitą architektūrinị elementą. Paviršių estetika, kilusi iš techninès estetikos, Lietuvos architektūroje iki šiol nepraranda populiarumo, tai galima sieti su nemažèjančiu verslo ir administracinių centrų poreikiu, aukštuminių pastatų atsiradimu. Slick-tech estetika paskatino didesni susidomèjimą paviršių, kaip autonominių pastato elementų panaudojimu meninèje šiuolaikinès architektūros raiškoje, o tai sutampa su pasaulinèmis architektūros tendencijomis.

5. Postmodernioji architektūros meninè raiška, užsienio architektūroje matoma nuo septintojo dešimtmečio, Lietuvoje pradèjo reikštis tik devintojo dešimtmečio antroje pusèje. Išskirtinis Lietuvos postmoderniosios architektūros bruožas - istorinių elementų stilizacijos ir interpretacijos, iki 1990-ujų matomos vèlyvojo modernizmo formų kontekste, nuo 1995-ujų dažnai eklektiškame, ivairių naujų apdailos medžiagų naudojime. Vyraujantis dekoratyvusis postmodernizmas sukūrè chaotiškos architektūros laikotarpị, užgožusị pavienius simbolių ir ženklų interpretavimo bandymus postmoderniojoje Lietuvos architektūroje.

6. Šiuolaikinès Lietuvos architektūros meninę raišką formuoja techninè estetika, kritinio regionalizmo kryptis, dekonstruktyvizmo ir minimalizmo raiškos tendencijos.

7. Tyrimo metu atskleistos ir ịvardintos iki šiol Lietuvos architektū-rologijoje netyrinètos $\mathrm{XX}$ a. antros pusès architektūros kryptys atspindi nagrinèjamo laikmečio sociokultūrinius ir politinius procesus. 
Tyrimo medžiaga nustato Lietuvos architektūros meninès raiškos vietą pasauliniame kontekste, tuo pačiu išryškina vietinès architektūros savitumus. Naujai įvardintos kryptys ir tendencijos sukuria teorinį pagrindą tolesniems Lietuvos architektūros meninių procesų aiškinimams. 



\section{Literatūra ir šaltiniai}

Abrams, M. H. 1988. A glossary of literary terms. Fifth edition. New York: Holt, Rinehart \& Wilson.

Almonaitytè-Navickienè, V. 2008. Archiformos 2007 metų architektūros premija, Archiforma. 2008/1: 12-16.

Anderson, S. 2008. Architecture and Tradition That Isn't „Trad Dad“. Architectural Theory, vol II. An Antologhy from 1871-2005. Blackwell, p. 383-384.

Baldišiūtè, A. 2007. [interaktyvus] [žiūrèta 201306 12]. Prieiga per internetą: http://www.andrebaldi.lt/popup?pid=151\&photono $=2$.

Balmond, C. 1998. New Structure and the Informal. Cambridge: MIT Press.

Banham, R. 2008a. Theory and Design in the First Machine Age. Architectural Theory, vol II. An Antologhy from 1871-2005. Blackwell, p. 355-356.

Banham, R. 2008b. The Italian Retreat from Modern Architecture. Architectural Theory, vol II. An Antologhy from 1871-2005. Blackwell, p. 369-371.

Barr, A. H. 2008. What is Happening to Modern architecture. Architectural Theory, vol II. An Antologhy from 1871-2005. Blackwell, p. 280-282.

Behne, A. 2008. The Modern functional building. Architectural Theory, vol II. An Antologhy from 1871-2005. Blackwell, p. 213-214. 
Behrendt, W. C. 2000. The Victory of the New Building Style. Los Angeles CA: Getty program publications.

Bertoni, F. 2002. Minimalist Architecture. Basel: Birkhauser.

Betsky, A. 1998. Zaha Hadid. The Complete Buildings and Projects. London: Thames and Hudson.

Bloom, H.; Hartman, G. H.; Derrida, J.; Bloom, H.; de Man, P.; Miller, H. J. 1984. Deconstruction and criticism. New York: Continuum.

Bonta, J. P. 1977. Architecture and its interpretation: a study of expressive systems in architecture. New York: Rizzoli.

Breitschmidt, M. 2004. Can architectural art-form be designed out of construction? Carl Boetticher, Gottfried Semper, and Heinrich Woelfflin: a sketch of various investigations on the nature of "Tectonic" in nineteenth-century architectural theory. Blacksburg: Architecture Edition.

Brown, S. D. 2008. Learning from Pop. Architectural Theory, vol II. An Antologhy from 1871-2005. Blackwell, p. 436-438.

Buivydas, R. 1999a. XX a. architektūra: istorizmas. Archiforma 1999/1. p. 72-76.

Buivydas, R. 1999b. XX a. architektūra: iracionalizmas. Archiforma 1999/2. p. 71-77.

Buivydas, R. 2004a. Struktūralistinė architektūra: esmès ir sąveikos. Urbanistika ir architektüra. Vilnius: Technika. T. XXVIII, nr. 3, p. 95-101.

Buivydas, R. 2004b. Architektūriniai struktūrizavimo idèjos reflektai. Urbanistika ir architektūra. Vilnius: Technika. T. XXVIII, nr. 3, priedas, p. 107-116.

Buivydas, R. 2006a. Lietuviškieji XX a. reprezentacinès architektūros variantai. Architektūra: pozityvai ir negatyvai. Vilnius: Ex Arte. p. 12-25.

Buivydas, R. 2006b. Neįvardytas, bet svarbus šiuolaikinès architektūros reiškinys. Architektūra: pozityvai ir negatyvai. Vilnius: Ex Arte, 2006. p. 48-64.

Buivydas, R. 2012. Kai kas apie dvidešimties metų architektūrą. Laisvès architektūra. Vilnius: Baltos lankos.

Cache, B. 1999. Digital Semper. New York: Anyone.

Canizaro, V. B. 2007. Architectural Regionalism. New York: Princeton.

Charleson, A. W. 2005. Structure as architecture. Oxford: Elsevier.

Chino M. 2010. Construction Complete on the UK's Stunning Seed Cathedral. [interaktyvus] [žiūrèta $2010 \mathrm{~m}$. Lapkričio $6 \mathrm{~d}$.]. Prieiga per internetą: $<$ http://www.inhabitat.com/2010/04/05/construction-complete-on-the-uks-stunningseed-cathedral/>

Colquhoun, A. 1985. Historicism and the Limits of Semiology. Essays in Architectural Criticism: Modern Architecture and Historical Change. Cambridge, MA: MIT press. 
Cook, P. 1999. Walking City. [interaktyvus] [žiūrèta 201211 24]. Prieiga per internetą: $<$ www. Archigram. net>

Croci, V. 2010. Dynamic Light. The Media Facades of Realities: United. Architectural Design. Turkey. At the Threshold. January/February: 136-139.

Culler, J. D. 2007. On deconstruction: theory and criticism after structuralism. Cornell university press.

Daunora, Z. 2003. Vilniaus miesto centrinės dalies vizualinio identiteto apsaugos prioritetai. Urbanistika ir architektüra. Vilnius: Technika. XXVII tomas, nr. 1. p. 1223.

Davies, C. 1988. High Tech Architecture. New York: Rizzoli.

Dempsey, A. 2004. Stiliai, judejjimai ir kryptys. Enciklopedinis moderniojo meno vadovas. Vilnius: Presvika.

Drèmaitè, M.; Petrulis, V.; Tutlytė, J. 2012. Architektūra sovietinèje Lietuvoje. Vilnius: VDA leidykla.

Fathy, H. 1973. Architecture for the Poor: An Experiment in Rural Egypt. Chicago: University of Chicago Press.

Fleig, K. 1975. Alvar Aalto. London: Thames \& Hudson.

Ford, K. 2008. Modern is Regional. Architectural Theory, vol II. An Antologhy from 1871-2005. Blackwell, p. 264-265.

Foster, H. 1983. Postmodernism: A Preface. Anti-Aesthetic. Essays on Postmodern Culture. Seattle: Bay Press. p. 16-31.

Frampton, K. 2006. The Evolution of 20th-Century Architecture: A Synoptic Account. New York:Springer.

Frampton, K. 2007. Modern Architecture. A Critical History. London: Thames \& Hudson.

Frampton, K.1983. Towards a Critical Regionalism: Six Points for an Architecture of Resistance. The Anti-Aesthetic. Essays on Postmodern Culture. Seattle WA: Bay Press. p. 16-30.

Furuyama, M. 2006. Tadao Ando. Koln: Taschen.

Gabrènas, A. 2012. Medis šiuolaikineje lietuvos architektüroje: tradicijos ir novacijos. Daktaro disertacija. Vilnius: Technika.

Gadanho, P. 2007. Interrogating pop in Architecture. Berlin: Konrad Daniela.

Garcia, M. 2006. Prologue for a History and Theory of Architextiles, Architectural Design. Architextiles. November/December: 12-20.

Garcia, M. 2009. Patterns of Architecture. Architectural Design. November/December 2009, London: Wiley, p. 74-80. 
Gerliakas, K. 1993. V. Čekanausko projektuotų pastatų apžvalga. Vilniaus architektūros mokykla XVIII-XX a. Vilnius: VDA leidykla, p. 148-156.

Gerliakas, K. 1996a. Gediminas Baravykas: asmenybė ir kalba. Archiforma 1996/1. p. 60-65.

Gerliakas, K. 1996b. Lietuvos architektūros būsena: kontekstas, reikšmè, užsakovas. Archiforma 1996/2. p. 26-29.

Giedion, S. 2008. The State of Contemporary Architecture. Architectural Theory, vol II. An Antologhy from 1871-2005. Blackwell, p. 304-306.

Gilbert-Rolfe, J. 1999. Frank Gehry. City and Music. London: Rouletge.

Grafton, A; Rosenberg, D. 2010. Cartographies of Time: A History of the Timeline. Princeton Architectural Press.

Graves, M. 1982. Michael Graves: Buildings and Projects 1966-1981. New York: Rizzoli.

Gropius, W. 2008. International Architecture. Architectural Theory, vol II. An Antologhy from 1871-2005. Blackwell, p. 209-211.

Grunskis, T. 2005. Vietos tapatumo krizė Vilniaus centro raidoje (erdvès morfologijos diskurse). Urbanistika ir architektūra. Vilnius: Technika. p. 13-18.

Grunskis, T. 2012 „Kažkas atsitiko...“. Septynios pastabos apie architektūrinę laisvę ir laisvès architektūrą. Laisvès architektūra. Vilnius: Baltos lankos. p. 15-37.

Grunskis, T.; Reklaitė, J. 2012. Laisvès architektūra. Vilnius: Baltos lankos.

Habermas, J. 1981. Modern and Postmodern Architecture. Architecture theory since 1968. Cambridge: MIT Press: 412-428.

Hays, M. K. 1998. Architecture Theory since 1968. New York: MIT press.

Harris, H. H. 2008. Regionalism and Nationalism. Architectural Theory, vol II. An Antologhy from 1871-2005. Blackwell, p. 288-289.

Heyer, P. 1993. American Architecture: Ideas and Ideologies in the Late Twentieth Century. John Wiley and Sons.

Hertzberger, H. 2008. Homework for More Hospitable Form. Architectural Theory, vol II. An Antologhy from 1871-2005. Blackwell, p. 440-442.

Hill, J. 1996. Parc de la Villette. [interaktyvus] [žiūrèta 201203 13]. Prieiga per internetą: <www.Archidose.org>

Jackson, N. 1990. Metal-Frame Housesof the Modern Movement in Los Angeles. Part 2. New York: Rizzoli.

Jencks, Ch. 1980. Late-Modern Architecture. NY: Rizzoli.

Jencks, Ch. 1986. What is Post-Modernism. London: Academy editions.

Jencks, Ch. 1987. Post-Modernism, The New Classicism in Art and Architecture. NY: Rizzoli. 
Jencks, Ch. 1990. The New Moderns. London: John Wiley and Sons.

Jencks, Ch. 1991. The Language of Post-Modern Architecture. London: Academy editions.

Jencks, Ch. 1997. Architecture of the jumping universe. London: Academy Editions.

Jencks, Ch. 2000a. Architecture 2000 and Beyond. London: Wiley.

Jencks, Ch. 2000b. Jencks's Theory of Evolution, an Overview of 20'th Century Architecture. Architectural Review. July. p. 76-79.

Jencks, Ch. 2007. Critical Modernism - Where is Post Modernism Going? London: Wiley.

Jencks, Ch. 2011. The Story of Post-Modernism. Five Decades of the Ironic, Iconic and Critical Architecture. London: John Wiley and Sons.

Jencks, Ch., Chaitkin, W. 1982. Architecture today. New York: Academy Editions.

Jodidio, P. 2001. New Forms. Architecture in the 1990's. London: Taschen.

Jukštas, V. 1976. Architektûros savitumai - prielaida jos nacionaliniams bruožams formuotis. Statyba ir architektūra. $1976 \mathrm{nr}$. 1, p. 10-15.

Kipnis, J. 1993. Towards a New Architecture. Architectural Design. 102 March/April p. 56-66.

Kučinskas, R. 2006. Halès turgaus rekonstrukcija. Archiforma. 2006/3. p. 18-21

Kučinskas, R. 2009. Globalios architektūros pavidalai Vilniaus kontekste. Mokslas Lietuvos ateitis 1(2). Vilnius: Technika. p. 49-53.

Kwinter, S. 1986. La Citta Nuova: Modernity and Continuity. Architecture theory since 1968. Cambridge: MIT Press.

Lahti, L. 2004. Aalto. Koln: Taschen.

Le Corbusier. 1973. The Athens Charter. New York: Grossman.

Le Corbusier; Jeanneret, P. 1970. Programs and Manifestoes on 20th-Century Architecture. Cambridge, MA: MIT Press.

Leach, N. 2007. Rethinking Architecture: A Reader in Cultural Theory. London: Routledge.

Leatherbarrow, D.; Mostafavi, M. 2002. Surface Architecture. London. MIT press.

Libeskind, D. 1981. Between Zero and Infinity: Selected projects in Architecture. New York: Rizzoli.

Lynn, G, 1993a. Architectural Curvilinearity: The Folded, the Pliant and the Supple. Architectural Design. 102 March/April p. 8-9.

Lynn, G, 1993b. Folding in Architecture. Architectural Design. 102 March/April p. 914. 
Lupeikis, K. 2001. Minimalizmo raiškos šiuolaikinèje architektūroje kilmès priežastingumo analizè. Urbanistika ir architektūra. Vilnius: Technika. XXV tomas, nr. 3, p. 141-147.

Lupeikis, K. 2002. Minimalizmo aspektai Lietuvos architektūroje. Urbanistika ir architektūra. Vilnius: Technika. XXVI tomas, nr. 3. p. 114-124.

Lupeikis, K. 2004. Minimalistinès formos savitumo aspektai. Urbanistika ir architektūra. Vilnius: Technika. XXVIII tomas, nr. 3, p. 102-112.

Lupeikis, K. 2005. Minimalistinès raiškos tikslai ir prioritetai šiuolaikinèje architektūroje. Urbanistika ir architektūra. Vilnius: Technika. vol. 29, nr. 3, p. 131140 .

Lupeikis, K. 2007. Minimalizmo galia.. Vilnius: Technika.

Mačiulis, A. 1993. Prieštaringas dešimtmetis. Vilniaus architektūros mokykla XVIII$X X a$. Vilnius: VDA leidykla. p. 146-147.

Mačiulis, A. 1996. Naujasis manierizmas. Archiforma. 1996/2. p. 21-25.

Mačiulis, A. 1997. Architektūra. Stiliai, kompozicija, menu squeika. Vilnius: VDA leidykla.

Mačiulis, A. 1999. „Tautinès“ architektūros ieškojimai pokario Lietuvoje ir emigracijoje. Urbanistika ir architektūra, XXIII tomas, Nr. 1, p. 3-11.

Mačiulis, A. 2003. Dailè architektūroje. Vilnius: VDA leidykla.

Mačiulis, A. 2002. Modernioji architektūra. Lietuvos dailès istorija. Vilnius: VDA leidykla. p. 338-342.

Mačiulis, A. 2004a. Mokslinès konferencijos, skirtos Lietuvos architektu sajungos 80mečiui, medžiaga. Vilnius, $2004 \mathrm{~m}$. spalio $7 \mathrm{~d}$.

Mačiulis, A. 2004b. Architektai Simonas ir Gytis Ramuniai. Vilnius: VDA leidykla.

Mačiulis, A. 2007. Architektai Algimantas ir Vytautas Nasvyčiai. Vilnius: VDA leidykla.

Mačiulis, A. 2008. Kičo apraiškos šiuolaikiniame interjere. Urbanistika ir architektūra. 32(3). p. 167-172.

Mačiulis, A. 2011. Vytautas Edmundas Čekanauskas. Vilnius: VDA leidykla.

Makovsky, P. 2011. [interaktyvus] [žiūrèta 201307 22]. Prieiga per internetą: <http://www.metropolismag.com/April-2011/Our-Charles-Jencks-Moment/>

Maldonado, T. 2008. Notes on Communication. Architectural Theory, vol II. An Antologhy from 1871-2005. Blackwell, p. 377-379.

Mallgrave, H. F. 2008. Architectural Theory, vol II. An Antologhy from 1871-2005. Blackwell. 
Mallgrave, H. F.; Contandriopoulos, Ch. 2008. Coop Himmelblau. Architecture Must Blaze. Architectural Theory, vol II. An Antologhy from 1871-2005. Blackwell, p. 477479.

Mallgrave, H. F.; Goodmann, D. 2011. An Introduction to Architectural Theory. 1968 To the Present. John Wiley \& Sons.

Mankus, M. 2012. Administracinis pastatas "Pirklių klubas", Gedimino pr. 35, Vilnius. Archiforma. 2012/1-2. p. 17-24.

Markejevaitè, L. 1998. Leonidas Merkinas „Architektūra - tai mastymo būdas“. Archiforma. 1998/3. p. 28-33.

Matulevičiūtè, J. 1999. Dailès žodynas. Vilnius: Vaga. p. 401.

Meyer, A.; Kuhlbrodt, S. 2008. Architecture - A Synoptic Vision. Zurich:ETHZ.

Melvin. J. 2008. ...izmai. Vilnius: Mūsų knyga.

Minkevičius, J. 2012. Prieštaringoji laisvès architektūra - kultūrinès kokybès dimensija. Laisvés Architektūra. Vilnius: Baltos lankos. p. 202-209.

Mumford, L. 1972. Roots Of Contemporary American Architecture. New York: Dover.

Mumford, L. 2008. Status quo. Architectural Theory, vol II. An Antologhy from 18712005. Blackwell, p. 278-280.

Nekrošius, L. 2006a. Europietiškų struktūralizmo idèjų paralelès Lietuvos architektūroje. Urbanistika ir architektūra.. T. 30, nr. 3. Vilnius: Technika, p. 111124.

Nekrošius, L. 2006b. Struktūralistiniai kūrybos principai XX a. 8-ojo dešimtmečio Lietuvos architektūroje. Tradicija, autorystè, kürinio ribos ir interpretacijos laisvé. Vilnius: Lietuvos muzikos ir teatro akademija. p.283-299.

Nekrošius, L. 2008. Struktūralizmo idèjos šiuolaikinejje Lietuvos architektūroje. Daktaro disertacija. Vilnius: Technika.

Norberg-Schulz, Ch. 2008. Intentions in Architecture. Architectural Theory, vol II. An Antologhy from 1871-2005. Blackwell, p. 380-382.

Norberg-Shulz, Ch. 1971. Existence, Space and Architecture. New York: Praeger.

Norris, C. 1982. Deconstruction: theory and practice. London: Methuen.

Oliver, P. 2003. Dwellings: The Vernacular House Worldwide. London: Phaidon Press.

Palaima, J. 2006. Harmonija architektūroje: proporcijos ir mastelis. Vilnius: VDA leidykla.

Papadakes, A. 1988. Deconstruction in Architecture. London: Academy Editions.

Pawson, J. 1996. Minimum. London: Phaidon Press. 
Perrella, S. 1998. Hypersurface Theory: Architecture Culture. Architectural design 5/6: 7-8.

Petrulis, V. 2005. Nacionalinio savitumo strategijos sovietmečio Lietuvos architektūroje. Urbanistika ir architektūra. XXIX tomas, nr. 1. Vilnius: Technika. p. 3-12.

Petrulis, V. 2006. Stilistinès sovietmečio architektūros vertinimo prielaidos. Urbanistika ir architektūra, XXX tomas, Nr.3. Vilnius: Technika. p. 134-142.

Petrulis, V. 2007. Sovietmečio palikimas kaip etinis imperatyvas šiuolaikinei Lietuvos architektūrai. Urbanistika ir architektūra, XXXI tomas, Nr. 1. Vilnius: Technika. p.43-49.

Petrulis, V. 2012a. Epocha ir architektūra: politiniai - ideologiniai kontekstai. Architektūra sovietineje Lietuvoje. Vilnius: VDA leidykla. p. 23-50.

Petrulis, V. 2012b. Socialistinis modernizmas. Architektūra sovietinèje Lietuvoje. Vilnius: VDA leidykla. p.84-107.

Quinn, B. 2006. Textiles in Architecture, Architectural Design. Architextiles. November/December: 13-16.

Reyner, B. 2008. The New Brutalism. Architectural Theory, vol II. An Antologhy from 1871-2005. Blackwell, p. 308-310.

Reklaitè, J.; Leitanaitè, R. 2012. Vilniaus architektūros gidas 1900-2012. Vilnius: Baltos lankos.

Richards, J. M. 2008. The New Empiricism. Architectural Theory, vol II. An Antologhy from 1871-2005. Blackwell, p. 296-297.

Rykwert, J. 2008. Meaning and Building. Architectural Theory, vol II. An Antologhy from 1871-2005. Blackwell, p. 375-377.

Rogers, E. N. 2008. The Evoloution of Architecture: An Answer to the Caretaker of Frigidaires. Architectural Theory, vol II. An Antologhy from 1871-2005. Blackwell, p. 371-373.

Rossell, Q. 2005. Minimalist Interiors. New York: HapperCollins.

Rossi, A. 2008. The Architecture of the City. Architectural Theory, vol II. An Antologhy from 1871-2005. Blackwell, p. 386-388.

Routio, P. 2007. Arteology - the Science of Products and Professions. [interaktyvus] [žiūrèta 201002 17]. Prieiga per internetą: <http://www2.uiah.fi/projects/metodi>

Rowe, C., Koetter, F. 2008a. Collage City. Architectural Theory, vol II. An Antologhy from 1871-2005. Blackwell, p. 444-446.

Rowe, C.; Slutzky, R. 2008b. Transparency: Literal and Phenomenal. Architectural Theory, vol II. An Antologhy from 1871-2005. Blackwell, p. 379-341. 
Samalavičius, A. L. 2011. The vanishing Genius Loci of Vilnius. Eurozine. Vienna: Eurozine. ISSN 1684-4637. p. [1-7]. [Interaktyvus] [žiūrèta 201307 19]. Prieiga per internetą: <http://www.eurozine.com/pdf/2011-03-15-samalavicius-en.pdf>

Savin, B. M.; Major, C. 2013. Qualitative Research: The Essentail Guide to Theory and Practice. London: Routledge.

Schumacher, P. 2008. Parametricism as style - Parametricist manifesto. [interaktyvus] [žiūreta $2009 \quad 12$ 02]. Prieiga per internetą: $<\mathrm{http}: / / \mathrm{www}$. patrikschumacher.com/Texts/Parametricism\%20as\%20Style.htm>

Schumacher, S. P. 2011. The Autopoiesis of Architecture: A New Framework For Architecture. Vol. 1. London: Wiley \& Sons.

Schumacher, S. P. 2012. The Autopoiesis of Architecture: A New Agenda For Architecture. Vol. 2. London: Wiley \& Sons.

Sennott, R. 2004. Encyclopedia of $20^{\text {th }}$ Century Architecture. New York: Taylor and Francis.

Slessor, C. 2009. [interaktyvus] [žiūrèta 201305 25]. Prieiga per internetą: $<$ http://www.architectural-review.com/andalusias-museum-of-memory-by-albertocampo-baeza-granada-spain/8600956.article>

Small, D.; Rothenberg, J. 2006. Design Research on Responsive Display Prototypes: Integrating, Sensing, Information and Computation Technologies. Architectural Design. September/October.: 46-49.

Stasiulis, E. 2010. Forma architektūroje. Vilnius. VDA leidykla.

Stern A. M. R. 1980. The Doubles of Post-Modern. Harward Architectural Review 1. Cambridge, MA: MIT Press p. 84-86.

Stevens, I. 2009. Postmodernism, structuralism, post-structuralism, deconstruction and art criticism. [interaktyvus] [žiūrèta 2013 05 11]. Prieiga per internetą: <http://www.unisa.ac.za/default.asp?Cmd=ViewContent\&ContentID=7267>

Stirling, J. 1997. Ronchamp: Le Corbusier's Chapel and the Crisis of Rationalism. Theories and Manifestoes of Contemporary Architecture. John Wiley \& Sons. p. 16-18.

Štelbienè, A. 2013. Viešbučio „Santaka“ išplètimas. [Interaktyvus] [žiūrèta 201305 02]. Prieiga per internetą: <http://www.archmap.lt/objects/viesbucio-santakaispletimas/>

Tailor, M. C. 1993. Seaming. Newsline: Columbia Architecture, Planning, Preservation 6:1 (Sept/Oct) p. 5-18.

Team 10. 2008. The Aim of Team 10. Architectural Theory, vol II. An Antologhy from 1871-2005. Blackwell, p. 330-333.

Thorsen, K. T.; Greenwood, R. 2010. Relying on Interdependencies. Snohetta in the Middle East. Architectural Design March/April: 89-95. 
Tschumi, B. 1987a. Cinégramme folie: le Parc de la Villette. Princeton Architectural Press.

Tschumi, B. 1987b. Disjunctions. Cambridge, MA: MIT Press.

Tschumi, B. 1997. The Architectural Paradox. Architecture theory since 1968. Cambridge: MIT Press: 214-230.

Tschumi, B. 2008. The Violence of Architecture. Architectural Theory, vol II. An Antologhy from 1871-2005. Blackwell, p. 463-465.

Tutlytė, J. 1998 UAB „Omnitel“ atstovybès administracinis pastatas Laisvės alèjoje. Kaunas. Archiforma. 1998/3. p. 16-18.

Tutlytė, J. 2005. Vilniaus architekturos gidas 1900-2005. Vilnius: Baltos lankos.

Tutlytè, J. 2012. Pokario modernizmas. Nuo tipinio iki tautinio. Vilniaus architektūros gidas 1900-2012. Vilnius: Baltos lankos.

Tzonis A.; Lefaivre L. 1981. The grid and the pathway. An introduction to the work of Dimitris and Suzana Antonakakis. Architecture in Greece. Athens. p. 164-178.

Tzonis, A.; Lefaivre, L. 1992. Architecture in Europe Since 1968. Memory and Invention. London: Thames \& Hudson.

Tzonis, A.; Lefaivre, L. 2003. Critical regionalism, Architecture and Identity in a Globalized World, Munich, Berlin, London. New York: Prestel.

Tzonis, A.; Lefaivre, L. 2011. Architecture of Regionalism in the Age of Globalization, Peaks and Valleys in the Flat World. London: Routledge.

Almonaitytè-Navickienè, V. 2007. KMU biblioteka ir informacijos centras. Archiforma. 2007/2. p. 17-22.

Valevičius, M. 2010. Miestu meninio apšvietimo istorine raida ir šiuolaikinès tendencijos. Daktaro disertacija. Vilnius, Technika.

Van der Rohe, L. M. 1991a. Skyscrapers. The Artless Word: Mies van der Rohe On the Building Art. Cambridge, MA: MIT Press, p. 240.

Van der Rohe, L. M. 1991b. The Office Building. The Artless Word: Mies van der Rohe On the Building Art. Cambridge, MA: MIT Press, p. 241.

Van Doesburg, T. 1974. Towards Plastic Architecture. New York: Macmillan.

Van Eyck, A. 2008. Is Architecture Going to Reconcile Basic Values? Architectural Theory, vol II. An Antologhy from 1871-2005. Blackwell, p. 373-375.

Vanagas, J. 2003. Miesto teorija. Vilnius: VDA leidykla.

Vengalytè, L. 2006. „Stiklo linija“ ir „Šviesos studija“ būstinè. Archiforma. 2006/3. p. 22-25.

Venturi, R. 1966. Complexity and Contradiction in Architecture. New York: Museum of Modern Art. 
Venturi, R.; Brown, S. D.; Izenour, S. 1972 - Learning from Las Vegas. Cambridge: MIT Press.

Vyšniūnas. A; Daunora Z. J.; Kirvaitienė S. 2004. Vilniaus miesto vizualinio identiteto apsauga ir plètros principai. Vilnius: Technika.

Wigley, M. 1988. Deconstructivist architecture. New York: Museum of Modern Art. Zevi, B. 2008. Towards an Organic Architecture. Architectural Theory, vol II. An Antologhy from 1871-2005. Blackwell, p. 294-295. 



\section{Autoriaus mokslinių publikacijų disertacijos tema sąrašas}

Straipsniai recenzuojamuose mokslo žurnaluose

Mačiulis, M. A. 2010. Iracionalumo apraiškos XX a. užsienio ir Lietuvos architektūroje / Irrationality in Global and Lithuanian Architecture of the 20'th Century. Urbanistika ir Architektūra / Town planning and Architecture. 34(3). p. 151-160. ISSN 1392-1630.

Lupeikis, K.; Mačiulis, M. A., 2011. 4D Architektūroje / 4D in Architecture. Urbanistika ir architektūra / Town planning and Architecture. 35(1): 28-37. ISSN 1392-1630.

Mačiulis, M. A. 2012. Paviršius ir forma šiuolaikinejje architektūroje / Surface and Form in Contemporary Architecture. Mokslas - Lietuvos ateitis / Science - Future of Lithuania. 4(2). p. 144-152. ISSN 2029-2341. 



\section{Paveikslų sąrašas}

1. Principinè tyrimo schema.

2. Miestų statybos projektavimo institutas Vilniuje, archit. E. Chlomauskas, $1961 \mathrm{~m}$.

3. Pramoninès statybos projektavimo institutas (dab. verslo centras) Kaune, archit. A. Sprindys, V. Stauskas ir kt. 1959-1965 m.

4. Tipinio universalinès parduotuvès pastato fragmentas, archit. A. Patalauskas, 1966-1969 m.

5. Gamyklos pastatas Beeston mieste, D. Britanijoje, archit. O. Williams, $1932 \mathrm{~m}$.

6. Kauno technologijos universiteto pastatas (buv. KPI), archit. V. Dičius, 1964-1970 m.

7. Baldų parduotuvė Kaune, archit. V. Dičius, 1963-1969 m. Maketas.

8. Statybininku namai Vilniuje, archit. A. Mačiulis, $1964 \mathrm{~m}$.

9. Bauhaus mokyklos pastatas Dessau, Vokietija, archit. V. Gropius, $1926 \mathrm{~m}$.

10. Ūkio ministerijos pastatas Vilniuje, archit. E. N. Bučiūtè, 1973 m.

11. Seagram administracinis pastatas Niujorke, JAV, archit. M. van der Rohe, Ph. Johnson, $1958 \mathrm{~m}$.

12. Miestprojekto pastatas Kaune, archit. A. Sprindys, 1975 m. 
13. General Motors kompanijos techninis ir tyrimų centras Mičigane, JAV, archit. E. Saarinen, 1946-1955 m.

14. Vingio parko dainų estrada Vilniuje, archit. A. Kotli, H. Sepmann, $1960 \mathrm{~m}$.

15. Ledo arena Elektrenuose, konstr. A. Kanapeckas, $1960 \mathrm{~m}$.

16. Viešbutis Lietuva Vilniuje, archit. A. ir V. Nasvyčiai, 1967-1984 m.

17. Prekybos centras Merkurijus Kaune, archit. A. Sprindys, 1969-1983 m.

18. Gyvenamujų namų kvartalas Venecijoje, Italijoje, archit. G. de Carlo, 1980-1985 m.

19. Teismo rūmų pastatas Sevilijoje, Ispanijoje, archit. R. Armado, L. Domenech, 1982-1990 m.

20. Teismo rūmų pastatas Sevilijoje, Ispanijoje, archit. R. Armado, L. Domenech, 1982-1990 m.

21. Daugiabutis gyvenamasis namas Sevilijoje, Ispanijoje, archit. A. Cruz, A. Ortiz, 1974-1976 m.

22. Romėnų meno muziejus Meridoje, Ispanija, (planas) archit. R. Moneo, 1980-1986 m.

23. Romėnų meno muziejus Meridoje, Ispanija, archit. R. Moneo, 1980-1986 $\mathrm{m}$.

24. Bagsvaerd bažnyčia Kopenhagoje, Danijoje, archit. J. Utzon, 1976 m.

25. Bagsvaerd bažnyčia Kopenhagoje, Danijoje (maketo pjūvis), archit. J.Utzon, $1976 \mathrm{~m}$.

26. Daugiabutis gyvenamasis namas Barselonoje, Ispanijoje, archit. J. A. Coderch, $1951 \mathrm{~m}$.

27. Gyvenamieji namai Kobejje, Japonijoje, archit. T. Ando, $2005 \mathrm{~m}$.

28. Tipinis Kino teatro pastatas Druskininkuose, archit. V. Juršys, $1965 \mathrm{~m}$

29. Gyvenamasis namas su dirbtuvèmis Vilniuje, archit. E. BergaitèBurneikienè, $1959 \mathrm{~m}$.

30. Kompozitorių namai Vilniuje, archit. V. E. Čekanauskas 1960-1966 m

31. A. Aalto studija Helsinkyje, Suomija, archit. A. Aalto, $1955 \mathrm{~m}$.

32. Kultūros centras Volfsburge, Vokietijoje, archit. A. Aalto, 1959-1962 m.

33. Šiuolaikinio meno centras Vilniuje, archit. V. E. Čekanauskas, $1965 \mathrm{~m}$.

34. Vidurinè mokykla Vilniuje, archit. E. N. Bučiūtè, $1969 \mathrm{~m}$.

35. Kolūkio centras Alksniupiuose, archit. A. Mačiulis, 1972-1981 m.

36. Vilniaus Dailès akademijos naujieji rūmai Vilniuje, archit. V. Brèdikis, V. Mikučianis, V. Nasvytis, $1981 \mathrm{~m}$.

37. Kino teatras Helios, Vilniuje, archit. G. Baravykas, $1966 \mathrm{~m}$. Rekonstruotas 2003, archit. L. Merkinas

38. Ryšių ministerijos pastatas Vilniuje, archit. J. Šeibokas, 1979 m.

39. Seimo rūmai Vilniuje, archit. A. ir V. Nasvyčiai, $1981 \mathrm{~m}$. 
40. Operos ir baleto teatras Vilniuje, archit. E. N. Bučiūtè, 1974 m

41. Poilsinè Dainava Pervalkoje, archit. V. Guogis, $1971 \mathrm{~m}$.

42. Restoranas Ešeriné Nidoje, archit. V. Guogis, $1977 \mathrm{~m}$.

43. Nidos miesto savivaldybè, archit. G. Tiškus, $1973 \mathrm{~m}$.

44. Laidojimo paslaugų rūmai. Tipinis projektas Panevèžyje, archit. G. Tiškus, $1970 \mathrm{~m}$.

45. Koplyčia Ronchamp, Prancūzijoje, archit. Le Corbusier, 1950-1951 m.

46. Jeilio universiteto meno galerija Niu Havene, JAV, archit. L. Kahn, 1951-1953 m.

47. Hunstantono mokykla Norfolke, Anglijoje, archit. P. ir A. Smithson, 1949-1954 m.

48. Kompozicija Anti-konstrukcija, T. Van Doesburg, $1923 \mathrm{~m}$

49. Jeilio universiteto Meno ir architektūros fakultetas Niu Havene, JAV, archit. P. Rudolph, $1963 \mathrm{~m}$

50. VRM kultūros rūmai Vilniuje, archit. A. Mačiulis, $1982 \mathrm{~m}$.

51. Villa Savoye, Poissy, Prancūzijoje, archit. Le Corbusier, P. Jeanneret, $1931 \mathrm{~m}$.

52. Poilsio namai Žilvinas, Palangoje, archit. A. Lèckas, 1969

53. Vokietijos paviljonas 1929 - uјų EXPO parodai Barselonoje, Ispanijoje, archit. L. Mies van der Rohe

54. Alaus baras Tauro Ragas Vilniuje, archit. A Mačiulis, 1974 m.

55. Vilniaus Koncertų ir sporto rūmai, archit. E. Chlomauskas, J. Kriukelis, Z. Liandzbergis, $1971 \mathrm{~m}$.

56. Vietinès valdžios administracinis pastatas Čandigare, Indijoje, archit. Le Corbusier, $1955 \mathrm{~m}$.

57. Jeilio universiteto ledo ritulio arena Konektikute, JAV, archit. E. Saarinen, 1953-1959 m.

58. J. F. Kennedy oro uosto terminalas Niujorke, JAV, archit. E. Saarinen, 1956-1962 m.

59. Vasaros Estrada Palangoje, archit. V. Gerulis, $1970 \mathrm{~m}$.

60. Santuokų rūmai Vilniuje, archit. G. Baravykas, $1974 \mathrm{~m}$.

61. Buv. Lietuvos koopertyvų sajungos administracinis pastatas Vilniuje, archit. J. Šeibokas, 1979 m.

62. Fizioterapijos gydyklų kompleksas Druskininkuose, archit. A. ir R. Šilinskai, $1981 \mathrm{~m}$.

63. Sanatorija Sūrutis Druskininkuose, archit. A. ir R. Šilinskai, 1982 m.

64. Lietuvos Nacionalinis dramos teatras Vilniuje, archit. V. ir A. Nasvyčiai, $1981 \mathrm{~m}$. 
65. Meno muziejus Teksase, JAV, archit. Ph. Johnson, $1972 \mathrm{~m}$.

66. Nacionalinès Meno galerijos Rytinis korpusas Vašingtone, JAV, archit. I. M. Pei, $1978 \mathrm{~m}$.

67. J. F. Kenedžio biblioteka Bostone, JAV, archit. I. M. Pei, 1979 m.

68. KTU Chemijos fakulteto auditorija Kaune, archit. V. Dičius, $1964 \mathrm{~m}$.

69. Nacionalinè dailès galerija Vilniuje, archit. G. Baravykas, V. Vielius, 1980 m. Rekonstrukcija 2009 m., archit. A. Bučas, G. Kuginys ir kt.

70. Kauno paveikslų galerija, archit. L.Gelgaudienè, J. Navakas, $1978 \mathrm{~m}$.

71. KTU dizaino ir technologijų fakulteto auditorijų korpusai, archit. D. Petkelienè $1984 \mathrm{~m}$.

72. Laidotuvių namai VIlniuje, archit. Č. Mazūras, 1975 - 1987 m.

73. Litexpo parodu centras Vilniuje, archit. E. Stasiulis, $1980 \mathrm{~m}$.

74. Lietuvos Mokslų akademijos poilsio namai Palangoje, archit. V. Dičius, L. Ziberkas, 1982.

75. Lietuvos Vaikų ir jaunimo Centras Vilniuje, archit. Č. Mazūras, 1985$1987 \mathrm{~m}$.

76. Austrijos radijo ir televizijos pastatas Vienoje, archit. G. Peichl 1970$1972 \mathrm{~m}$.

77. Biuru pastatas Madride, Ispanijoje, archit. R. Moneo, 1973-1976 m

78. Vilniaus keliu policijos pastato fragmentas, archit. G. Ramunis, K. Pempè ir kt., $1982 \mathrm{~m}$.

79. Antakalnio vaiku poliklinika Vilniuje, archit. R. Masilionyte, $1984 \mathrm{~m}$.

80. Administracinis draudimo bendrovès pastatas Apeldoorn, Olandijoje, archit. H. Hertzberger, $1972 \mathrm{~m}$.

81. Pensionas Žilvinèlis, Palangoje, archit. A. Lèckas, $1970 \mathrm{~m}$.

82. Poilsio namai Guboja Šventojoje, archit. R. Buivydas, 1976 m.

83. Olimpinis kompleksas Miunchene, Vokietijoje, archit. G. Behnisch, 1972 $\mathrm{m}$.

84. Kansai oro uosto terminalas Japonijoje, archit. R. Piano, 1988 - 1994 m.

85. Traukinių stotis Liono oro uoste, Prancūzijoje, archit. S. Calatrava, 1989$1994 \mathrm{~m}$.

86. Teismo rūmų kompleksas Antverpene, Belgijoje, archit. R. Rogers, 1998-2005 m.

87. Vizualiujų menu centras Norviče, Anglijoje, archit. N. Foster, 1975-1978 $\mathrm{m}$.

88. Gyv. namas Los Andžele, JAV, archit. H. Schulitz, 1976 m.

89. Gyv. namas Londone, Anglijoje, archit. M. Hopkins, 1978 m.

90. Gyv. namas Štutgarte, Vokietijoje, archit. W. Sobek, $2000 \mathrm{~m}$. 
91. Pompidou meno centras Paryžiuje, Prancūzijoje, archit. R. Piano, R. Rogers 1971-1977 m.

92. Administracinis pastatas Londone, Anglijoje, archit. R. Rogers, 1978$1986 \mathrm{~m}$.

93. Bankas Honkonge, Kinijoje, archit. N. Foster, 1986 m.

94. Arts viešbutis Barselonoje, Ispanijoje, archit. SOM, $1992 \mathrm{~m}$.

95. Medicinos tyrimų centras Achene, Vokietijoje, archit. Weber, Brandt und Partners 1968-1986 m.

96. Medicinos tyrimų centro Achene, Vokietijoje interjeras, archit. Weber, Brandt und Partners 1968-1986 m.

97. Administracinis pastatas Tokijuje, Japonijoje, archit. K. Kurokawa, 1982-1984 m.

98. Administracinio pastato Tokijuje, Japonijoje interjeras, archit. K. Kurokawa, 1982-1984 m.

99. Prekybos centro iejjimo fragmentas Vilniuje, archit. G. Jurevičius, A. Nasvytis, $2002 \mathrm{~m}$.

100. Administracinio pastato įejimo fragmentas Vilniuje, archit. A. Asauskas, V. Kančiauskas, $2005 \mathrm{~m}$.

101. Prekybos centro Europa Vilniuje interjeras, archit. A. Ambrasas $2002 \mathrm{~m}$. 102. Litexpo parodų centro Vilniuje interjeras, archit. R. Palekas, $2006 \mathrm{~m}$.

103. Baltasis tiltas Vilniuje, archit. A. Nasvytis ir kt., $1995 \mathrm{~m}$.

104. Muitinès postas Nidoje, archit. A. Blūšius ir kt., $2000 \mathrm{~m}$.

105. SBA baldų salonas Vilniuje, archit. S. Kuncevičius, A. Jakutis, $2000 \mathrm{~m}$.

106. SBA baldų salonas Vilniuje, archit. S. Kuncevičius, A. Jakutis, $2004 \mathrm{~m}$.

107. Sandèliavimo patalpų konversija ị administracines patalpas Kaune, archit. G.Natkevičius, R.Adomaitis, M.Mickevičius, 2005 m

108. Audi autosalonas Vilniuje, archit. A. Nasvytis, D. Svetikas, P. Jansonas $2000 \mathrm{~m}$.

109. Automodus autosalonas Vilniuje, archit. S. Mikštas, $2001 \mathrm{~m}$.

110. Fakto Auto autosalonas Vilniuje, archit. Eventuspro, $2002 \mathrm{~m}$.

111. Viešbutis Los Andžele, JAV, archit. J. Portman, 1974-1977 m.

112. Administracinis pastatas Hiustone, JAV, archit. J. Burgee, Ph. Johnson, $1976 \mathrm{~m}$.

113. Viešbutis Dalase, JAV, archit. W. Becket, 1976-1978 m.

114. Administracinis pastatas Ipsviče, Anglijoje, archit. N. Foster, 1972$1975 \mathrm{~m}$.

115. Biuru pastatas Vilniuje, archit. R. ir A. Ambrasai, $2001 \mathrm{~m}$.

116. Administracinis pastatas Kaune, archit. V. Juozaitis, $2004 \mathrm{~m}$. 
117. Verslo centras Vilniuje, archit. L. Merkinas, L. Žičkis ir kt. 2008 m.

118. Polifunkcinis kompleksas Vilniuje, archit. R. Bimba, G. Adlys ir kt., 2007 $\mathrm{m}$.

119. Verslo centras Vilniuje, archit. R. Palekas, R. Bèčius ir kt. 2004-2005 m.

120. Verslo centras Vilniuje, archit. S. Pamerneckis ir kt. 2002-2003 m.

121. Verslo centras Vilniuje, archit. A. Ambrasas ir V. Adomonyte 2002-2004 $\mathrm{m}$

122. Polifunkcinis kompleksas Vilniuje, archit. R. Bimba $2004 \mathrm{~m}$.

123. Svedbank pastatas Vilniuje, archit. A. Ambrasas, $2009 \mathrm{~m}$.

124. Polifunkcinis kompleksas Kaune, archit. G. Natkevičius ir kt., $2008 \mathrm{~m}$

125. Polifunkcinis kompleksas Vilniuje, archit. A. Trimonis ir kt., $2012 \mathrm{~m}$.

126. Tarptautinis Kauno oro uostas, archit. G. Natkevičius, 2008 m.

127. Gyvenamasis namas Vilniuje, archit. G. Natkevičius, $2008 \mathrm{~m}$.

128. Etnokosmologijos muziejaus rekonstrukcija Molètu raj., archit. R. Krištapavičius ir A. Gudaitis 2008 m., (pirminio projekto autorius V. Lisauskas 1990 m.).

129. Lietuvos pavilijonas EXPO parodoje Hanoveryje, Vokietijoje, archit. G. Kuginis ir kt., $2000 \mathrm{~m}$.

130. Holoskin multifunkcinis pastatas Lilyje, Prancūzijoje, archit. L. Spuybroek, $2004 \mathrm{~m}$.

131. Cooper Union pastatas Niujorke, JAV, archit. Morphosis, $2009 \mathrm{~m}$.

132. Administracinis pastatas Prahoje, Čekijoje, archit. F. Gehry, 1992$1996 \mathrm{~m}$.

133. Visuomeninis pastatas Melburne, Australijoje, archit. $L A B, 2002 \mathrm{~m}$

134. Karaliaus Abdulazizo žinių ir kultūros centras Dhahrane, Saudo Arabijoje, archit. Snohetta. Vizualizacija

135. Karaliaus Abdulazizo žinių ir kultūros centras Dhahrane, Saudo Arabijoje, archit. Snohetta. Maketas

136. Media instaliacija BIX, Gracas, Austrija, aut. Realities:united, $2003 \mathrm{~m}$.

137. Media instaliacija Crystal Mesh, Singapūras, aut. Realities:united, $2009 \mathrm{~m}$.

138. Media instaliacija 555 Kubik, Hamburgas, Vokietija, aut. D. Rossa, 2010 m.

139. Aukštabalio multifunkcinis kompleksas Šiauliuose, archit. E Miliūnas, A. Bublys, G. Balčytis ir kt. 2007 m.

140. Administracinis Lietuvos Energijos pastatas Vilniuje, archit. K. Pempé, A. Pliučas, $2003 \mathrm{~m}$.

141. Banko pastatas Vilniuje, archit. S. Kuncevičius, A. Gabrènas, 2005 m. 
142. Kauno medicinos universiteto biblioteka ir informacijos centras, archit. G. Janulytė-Bernotienè, E. Riepšas, L. Bulakienè ir kt., $2006 \mathrm{~m}$.

143. Prasmès perteikimas naudojant architektūrinę raišką pagal R. Venturi, D. S. Brown ir S. Izenour. Viršuje skulptūrinis sprendimas, apačioje dekoratyvus.

144. Savivaldybès pastatas Hiustone, JAV, archit. TAFT, $1979 \mathrm{~m}$.

145. Mokykla Indianoje, JAV, archit. TAFT, $1986 \mathrm{~m}$.

146. Administracinis pastatas Niujorke, JAV, archit. Ph. Johnson, $1984 \mathrm{~m}$.

147. Administracinis pastatas Portlande, JAV, archit. M. Graves, 1980$1983 \mathrm{~m}$.

148. Administracinis pastatas Luisvilyje, JAV, archit. M. Graves, 1982$1986 \mathrm{~m}$.

149. Piazza d'Italia aikštès planas Naujajame Orleane, JAV, archit. Ch. Moore, 1975-1980 m.

150. Piazza d'Italia aikštė Naujajame Orleane, JAV, archit. Ch. Moore, 1975$1980 \mathrm{~m}$.

151. Kelionių agentūros biuro interjeras Vienoje, Austrijoje, archit. H. Holein, $1978 \mathrm{~m}$.

152. Klubas Palangoje, archit. R. ir A. Šilinskai, 1979 m.

153. Klaipedos dramos teatras, archit. S. Manomaitis 1979-1989 m.

154. Telekomunikacijų bendrovès atstovybè Kaune, archit. A. Rimša, E. Vilčinskas, D. Gutauskienè, 1998 m.

155. Kunigų seminarija Vilniuje, archit. M. Šaliamoras, J. Balkevičius, $1998 \mathrm{~m}$.

156. Polifunkcinis kompleksas Marijampoleje, archit. L. Tumynienè ir kt., $1993 \mathrm{~m}$.

157. Lazdijų rajono apygardos Teismo rūmai, archit. A. Mazūras, 1994 m.

158. Japonijos ambasada Vilniuje, archit. D. Ruseckas, 1997 m.

159. Švč. M. Marijos Krikščionių pagalbos bažnyčia Alytuje, archit. K. Kisielius, K. Pempè, G. Ramunis, 1994-2000 m.

160. Žvirgždaičių Švč. Jèzaus širdies bažnyčia, archit. K. Tamošètis, 2012

161. Lietuvos kankinių bažnyčia Domeikavoje, archit. VAS, 2006 m.

162. Kultūros paveldo ịstaiga Vilniuje, archit. A. Trimonis, A. Ambrasas, G. Adlys 1989-1990 m.

163. Dailininko K. Žoromskio galerija Vilniuje, archit. L. Merkinas, S. Šarkinas, 1996 m.

164. Polifunkcinis pastatas Vilniuje, archit. G. Ramunis, K. Pempè, 1998$1999 \mathrm{~m}$. 
165. Buvęs banko pastatas Panevėžyje, archit. V. Klimavičius, $1995 \mathrm{~m}$.

166. Daugiabutis gyvenamasis namas Vilniuje, archit. A. Trimonis, G. Čaikauskas, A. Ambrasas, 1986-1987 m.

167. Vytauto Didžiojo gimnazijos naujasis pastatas Vilniuje, archit. J. Makariūnas, $2002 \mathrm{~m}$.

168. Seimo viešbutis Vilniuje, archit. A. E. Paslaitis, $1989 \mathrm{~m}$.

169. Verslo centras Vilniuje, archit. A. Songaila, $2000 \mathrm{~m}$.

170. Konferencijų centras Vilniuje, archit. K. Pempè ir kt., 1999 m.

171. Krašto apsaugos ministerijos centrinis gynybinis štabas Vilniuje, archit. E. N. Bučiūtè, 1997 m.

172. SEB bankas Vilniuje, archit. K. Pempè, G. Ramunis, $1996 \mathrm{~m}$

173. Nidos bažnyčia, archit. R. Krištapavičius, A. Zaviša 2003 m.

174. Nidos menininkų kolonija, archit. A. Kančas, G. Kančaitė, T. Petreikis, T. Kučinskas, $2011 \mathrm{~m}$.

175. Viešbutis Klaipėdoje, archit. J. R. Palys, J. Audejjaitis, G. Kezys, 2007 m. 176. Viešbutis Klaipėdoje, archit. A. Stripinis, S. Stripinienè, E. Kaltanaite, K. Jurkutè 2007-2008 m.

177. Gyvenamasis namas Velingtone, N. Zelandijoje, archit. R. Walker, $1970 \mathrm{~m}$.

178. Gyvenamieji namai Reuse, Ispanijoje, archit. R. Bofill, 1964-1970 m.

179. Meno galerija Štutgarte, Vokietijoje, archit. J. Stirling, 1977-1982 m. Maketas.

180. Meno galerija Štutgarte, Vokietijoje, archit. J. Stirling, 1977-1982 m.

181. Prekybos kompleksas Šeškine, Vilniuje, archit. G Baravykas, G. Ramunis, K. Pempè, 1978-1985 m.

182. M. Žilinsko dailès galerija Kaune, archit. E. Miliūnas, K. Kisielius, S. Juškys, 1981-1988 m.

183. Lietuvos banko administracinis pastatas ir saugykla Klaipedoje, archit. J. Volungevičius, R. Lajus, $1996 \mathrm{~m}$.

184. Parc de la Villette Paryžiuje, Prancūzijoje, archit. B Tschumi, 1985 m. Projektas.

185. Parc de la Villette Paryžiuje, Prancūzijoje, archit. B Tschumi, 1985 m. Dekoratyvios pastogès.

186. IX Forto muziejus, Kaunas, archit. G. Baravykas, 1983 m.

187. Prekybos centras Žirmūnai, Vilniuje, archit. L. Merkinas, 1997 m.

188. Gyvenamojo namo priestatas Santa Monikoje, JAV, archit. F. Gehry, $1978 \mathrm{~m}$.

189. Guggenheimo muziejus Bilbao, Ispanijoje, archit. F. Gehry, 1997 m. 
190. BMW muziejus Miunchene, Vokietijoje, archit. Coop Himmelblau, 2007 $\mathrm{m}$.

191. Daugiabutis gyvenamasis namas Vilniuje, archit. V. Saveikis ir kt., $2001 \mathrm{~m}$.

192. Gyvenamasis namas Panevėžyje, archit. ARCHES, $2005 \mathrm{~m}$.

193. Gyvenamasis namas Panevėžyje, archit. ARCHES, 2005 m. Interjeras.

194. Administracinis pastatas Kaune, archit. G. Natkevičius, V. Kuliešius, $2001 \mathrm{~m}$.

195. Daugiabutis gyvenamasis namas Vilniuje, archit. PLAZMA, $2006 \mathrm{~m}$.

196. Gyvenamasis namas Kaune, archit. R. Raslavičius, 2010 m.

197. Gyvenamasis namas Birštone, archit. G. Natkevičius, $2011 \mathrm{~m}$.

198. Gyvenamasis namas Kaune, archit. G. Natkevičius, 2010 m.

199. Mokslinès kounikacijos ir informacijos centras Vilniuje, archit. R. Palekas, A. Palekienè, B. Puzonas, $2013 \mathrm{~m}$.

200. Gamtos muziejus Toronte, Kanadoje, archit. D. Libeskind, $2007 \mathrm{~m}$.

201. Honkongo universiteto kūrybinių medijų centras Kinijoje, archit. D. Libeskind, $2010 \mathrm{~m}$.

202. Kino teatru centras Dresdene, Vokietijoje, archit. Coop Himmelb(l)au, 1993-1998 m.

203. Nude Descending the Staircase, aut. M. Duchamp, $1912 \mathrm{~m}$.

204. Projekto eskizas, archit. Z. Hadid, $1990 \mathrm{~m}$.

205. Vitra dizaino muziejus, Weil am Rhein, Vokietija, archit. F. Gehry, 1989 m.

206. Didžiosios Britanijos pavilijonas 2010 EXPO parodoje Šanchajuje, Kinijoje, archit. T. Hatherwick

207. Pasaulio darnios plètros centras. Konkursinis projektas, archit. K. Lupeikis, $2010 \mathrm{~m}$.

208. Andalūzijos muziejus Granadoje, Ispanijoje, archit. A. Campo Baeza, $2009 \mathrm{~m}$.

209. Pėsčiujų tiltas Londone, D. Britanijoje, archit. J. Pawson, 2000-2006 m.

210. Brolio Klauso koplyčia Vachendorfe, Vokietijoje, archit. P. Zumthor, $2007 \mathrm{~m}$. Interjeras.

211. Meno centras Madride, Ispanijoje, archit. Herzog ir de Meuron, $2008 \mathrm{~m}$.

212. Gyvanamasis namas Kaune, archit. G. Natkevičius, R. Adomaitis, $2001 \mathrm{~m}$.

213. Gyvanamasis namas Alytuje, archit. G. Natkevičius, R. Adomaitis, $2002 \mathrm{~m}$. 
214. Gyvanamasis namas Kaune, archit. G. Natkevičius, T. Kuleša, L. Kraniauskas, $2009 \mathrm{~m}$.

215. Gyvanamasis namas Vilniuje, archit. G. Natkevičius, R. Adomaitis, R. Babrauskas, $2006 \mathrm{~m}$.

216. Pirtis Vilniuje, archit. G. Natkevičius, T. Kuleša, E. Spūdys, 2006 m.

217. Krematoriumas Kedainiuose, archit. G. Natkevičius, A. Rimšelis, A. Natkevičiūtè, $2011 \mathrm{~m}$.

218. Administracinis prokuratūrų pastatas Vilniuje, archit. K. Lupeikis, $2008 \mathrm{~m}$.

219. Bažnyčia Vilniuje, archit. D. Trainauskas, D. Baliukevičius, 2008 m. Vizualizacija.

220. Koplyčia Almadene, Ispanijoje, archit. S.M.A.O., 2001 m. Koncepcija.

221. Koplyčia Almadene, Ispanijoje, archit. S.M.A.O., $2001 \mathrm{~m}$.

222. Bažnyčios Vilniuje projektinis pasiūlymas, archit. A. Baldišiūtè, A. Neniškis, M. Jusaite, A. Tilvikaitè, L. Zwijsen, L. Rekevičius 2008 m. Maketas.

223. Konferencijų centras Šeduvoje, archit. D. Čiuta, G. Auželis, 2009 m.

224. Tankinimo schema Stambule, Trukijoje, archit. Z. Hadid, 2006 - m.

225. Guggenheimo-Ermitažo muziejus Vilniuje, archit. Z. Hadid, 2007 m. Vizualizacija.

226. Daugiabučiai namai Vilniuje, archit. T. Balčiūnas ir kt., 2008 m.

227. Gyvenamieji namai Vilniuje, archit. Eventuspro, $2005 \mathrm{~m}$.

228. Gyvenamasis namas Vilniuje, archit. R. Palekas, $2005 \mathrm{~m}$.

229. Infocentras Meteliuose, archit. G. Natkevičius, $2000 \mathrm{~m}$.

230. Mokslo technologijų parkas Vilniuje, archit. VAS, $2007 \mathrm{~m}$.

231. Sporto kompleksas Svenceleje, archit. A. Baldišiūtè ir kt., $2010 \mathrm{~m}$.

232. Moderniosios architektūros evoliucijos medis, Ch. Jencks, $2000 \mathrm{~m}$.

233. Vèlyvojo modernizmo meninès raiškos modelis, Ch. Jencks, $1982 \mathrm{~m}$.

234. Postmodernizmo meninès raiškos modelis, Ch. Jencks, $1982 \mathrm{~m}$.

235. Šiuolaikinès architektūros kryptys, P. Makovsky, 2007 m. 
Algimantas MAČIULIS

ŠIUOLAIKINĖS LIETUVOS ARCHITEKTŪROS

MENINĖS RAIŠKOS TENDENCIJOS

Daktaro disertacija

Humanitariniai mokslai, menotyra $(03 \mathrm{H})$,

Skulptūra ir architektūra (H312)

Algimantas MAČIULIS

TRENDS OF ARTISTIC EXPRESSION IN

CONTEMPORARY LITHUANIAN ARCHITECTURE

Doctoral Dissertation

Humanities, History and Theory of Arts $(03 \mathrm{H})$,

Sculpture and Architecture (H312)

201311 08. 16,25 sp. I. Tiražas 20 egz.

Vilniaus Gedimino technikos universiteto

leidykla „Technika“,

Saulètekio al. 11, 10223 Vilnius,

http://leidykla.vgtu.It

Spausdino UAB „Baltijos kopija“

Kareivių g. 13B, 09109 Vilnius 